\title{
Inventory of Glaciers in the Sierra Nevada, California
}

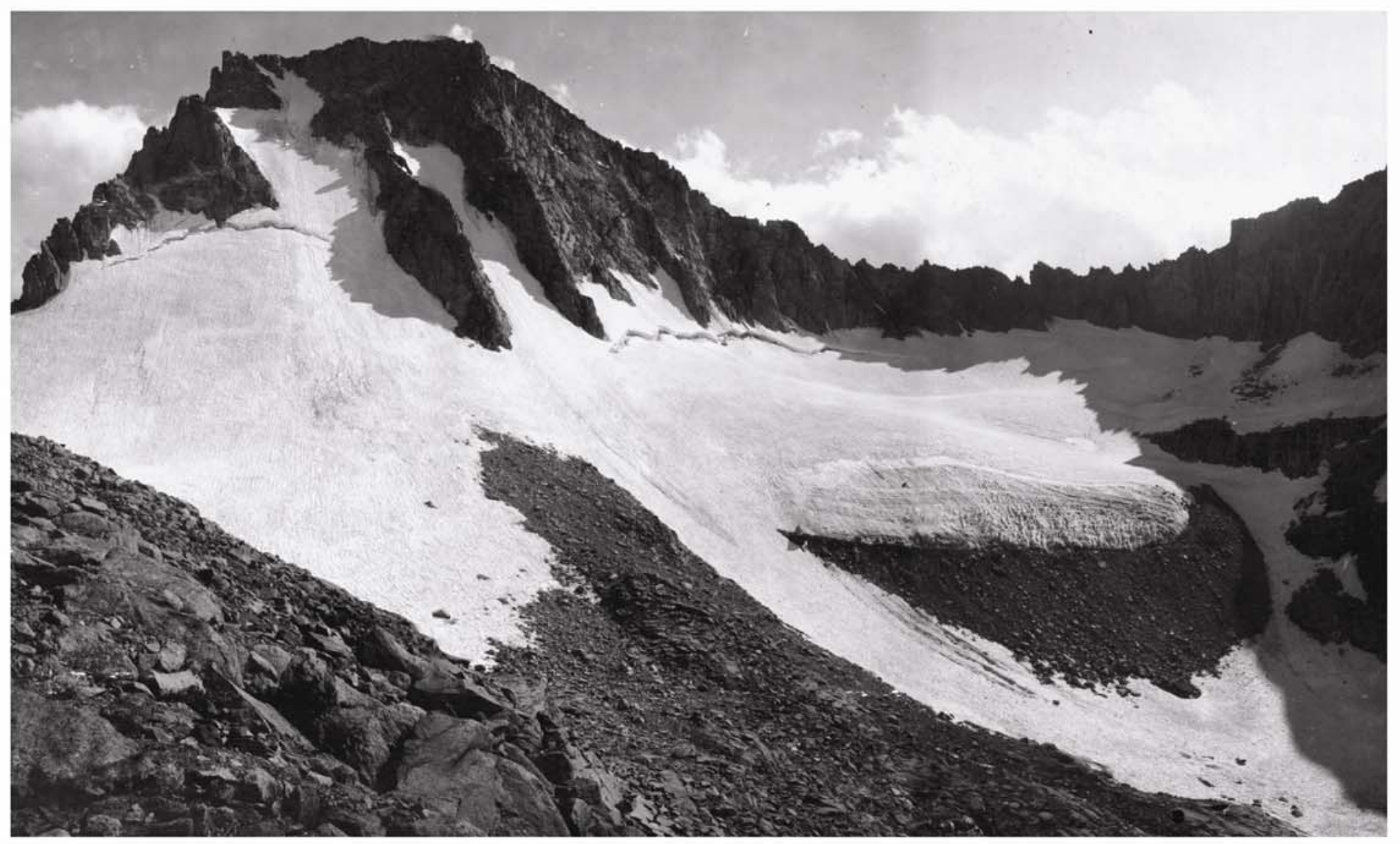

Open-File Report 2006-1239

U.S. Department of the Interior

U.S. Geological Survey 
Cover. Darwin Glacier, below Mount Darwin, Photo by G.K. Gilbert Kings Canyon National Park, California, August 14, 1908. The image is digitally stitched from photographs ggk0372, ggk0373, and ggk0374 archived at the US Geological Photo Library, Denver, CO. 


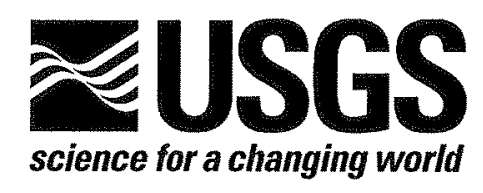

\section{Inventory of Glaciers in the Sierra Nevada, California}

By William Raub, C. Suzanne Brown, and Austin Post

Open-File Report 2006-1239

U.S. Department of the Interior

U.S. Geological Survey 


\title{
U.S. Department of the Interior \\ DIRK KEMPTHORNE, Secretary
}

\author{
U.S. Geological Survey \\ Mark D. Myers, Director
}

U.S. Geological Survey, Reston, Virginia 2006

For product and ordering information:

World Wide Web: http://www.usgs.gov/pubprod

Telephone: 1-888-ASK-USGS

For more information on the USGS-the Federal source for science about the Earth, its natural and living resources, natural hazards, and the environment:

World Wide Web: http://www.usgs.gov

Telephone: 1-888-ASK-USGS

Suggested citation:

Raub, W., Brown, C.S and Post, A., 2006, Inventory of Glaciers in the Sierra Nevada, California: U.S. Geological Survey Open-File Report 2006-1239, 232 p., online only

Any use of trade, product, or firm names is for descriptive purposes only and does not imply endorsement by the U.S. Government.

Although this report is in the public domain, permission must be secured from the individual copyright owners to reproduce any copyrighted material contained within this report. 


\section{Contents}

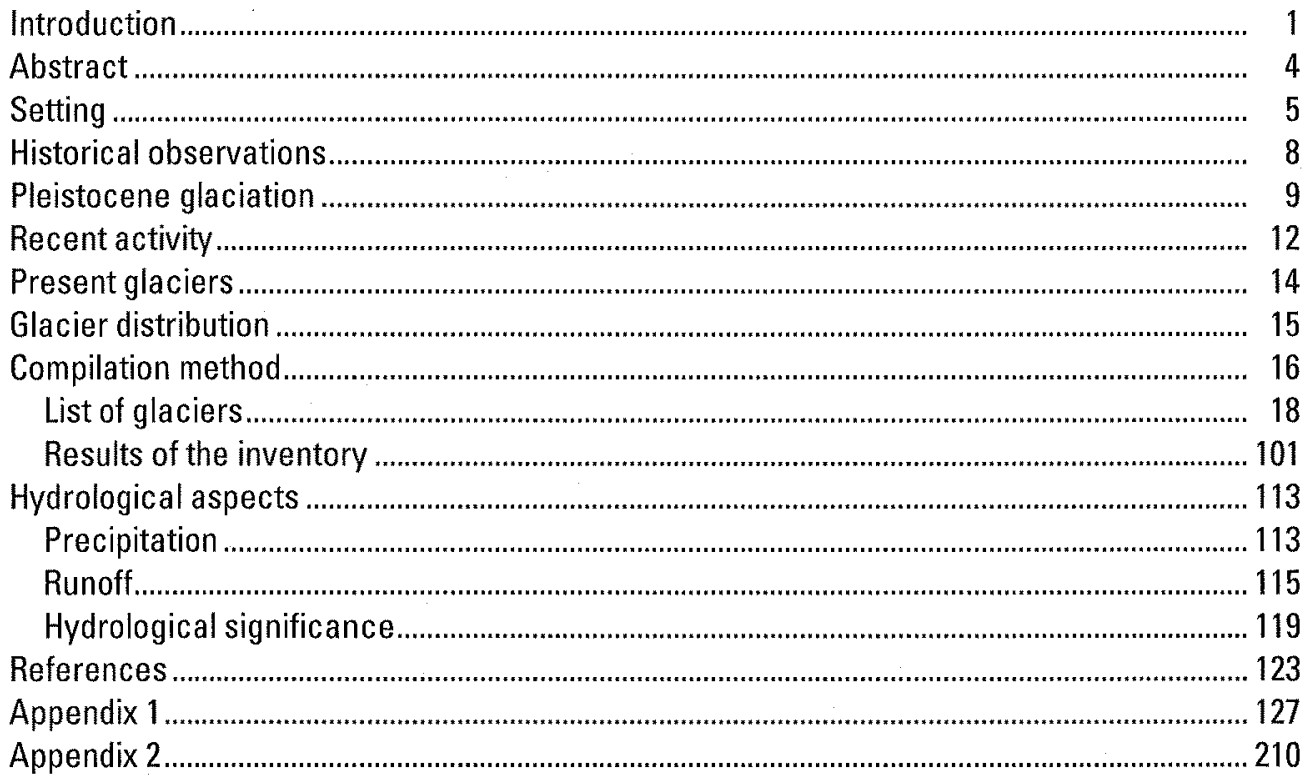

\section{Figures}

1. Orientation map of California and the Sierra Nevada.

2. Map showing Wisconsin glaciation and climatic firn limit int the Sierra Nevada and White Mountains.

3. Graph showing number of glaciers and ice patches by size class distribution...................... 104

4. Graph showing glacier and ice patch area by size class distribution .................................. 105

5. Diagrams showing orientation of glaciers west of the crest and east of the crest.............. 107

6. Graph of distribution of glaciers by terminus altitude ......................................................... 108

7. Graph of mean glacier altitude, by basin, versus total glacierized area of each basin ....... 109

8. Northwest to southwest profile along the glaciated crest of the Sierra Nevada showing topography and gradient of mean glaciers altitude .................................................... 111

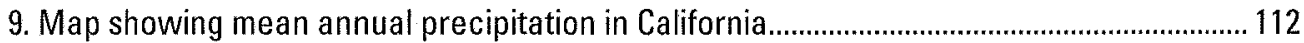

10. Graph illustrating snowfall variability at Donner Summit ......................................................... 114

11.Map showing the location of the glacierized basins in the Sierra Nevada ......................... 117

12. Graph showing comparison of times of maximum and minimum runoff in glacierized and nonglacierized basins

13. Depiction of the nonglaciated basin of Cottonwood Creek and the glaciated basin of Big Pine Creek. 


\section{Tables}

1A. Glaciers of the Sierra Nevada

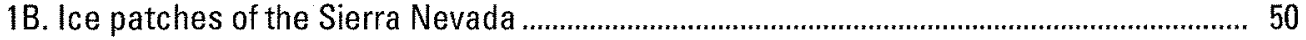

2. Sierra Nevada river basins and inventory identification numbers ..................................... 99

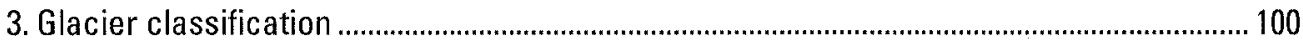

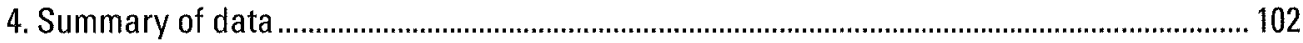

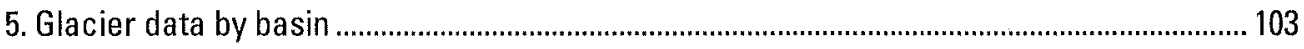

6 Comparison of hydrologic data from nonglacierized Cottonwood Creek with glacierized



\section{Plates}

(In pocket)

1. Topographic map of the central Sierra Nevada, California

2. Map showing glaciers and drainage basins of the central Sierra Nevada, California

3. Topographic map of the southern Sierra Nevada, California

4. Map showing glaciers and drainage basins of the southern Sierra Nevada, California

\section{Conversion Factors}

\begin{tabular}{lcl}
\hline Multiply & By & To obtain \\
\hline cubic foot $\left(\mathrm{ft}^{3}\right)$ & 0.02832 & cubic meter $\left(\mathrm{m}^{3}\right)$ \\
mile $(\mathrm{mi})$ & 1.609 & kilometer $(\mathrm{km})$ \\
foot $(\mathrm{ft})$ & 0.3048 & meter $(\mathrm{m})$ \\
inch (in.) & 25.4 & millimeter $(\mathrm{mm})$ \\
square mile $\left(\mathrm{mi}^{2}\right)$ & 2.590 & square kilometer $\left(\mathrm{km}^{2}\right)$ \\
\hline
\end{tabular}




\section{Inventory of Glaciers in the Sierra Nevada, California}

By William Raub, C Suzanne Brown, and Austin Post

\section{Forward}

The inventory of the Glaciers in the Sierra Nevada, California, was completed and being readied for publication in the Professional Paper series of the U.S. Geological Survey in late 1991. At that time, it was to be published as U.S. Geological Survey Professional Paper 705-B, the second chapter in a planned multi-chapter series of inventories of "Glaciers in the United States." The first in the series, U.S. Geological Survey Professional Paper 705-A had been published in 1971:

Post, Austin, Richardson, Don, Tangborn, W.V., and Rosselot, 1971, Inventory of glaciers in the North Cascades, Wash.: U.S. Geological Survey Professional Paper 705-A (Glaciers in the United States), $26 \mathrm{p}$. with plates in pocket.

A rough draft of U.S. Geological Survey Professional paper 705-C, Inventory of Glaciers in the Olymipic Peninsula, Wash., was written by Richard C. Spicer. This third chapter was based on his master's degree dissertation, and is being finalized for publication at the time of this writing.

Because of changing research priorities and budget limitations, the completed unpublished manuscript languished until Professor Andrew G. Fountain, Departments of Geology and Geography, Portland State University, Portland, Oregon 97207, who had been "storing" the manuscript, asked Richard S. Williams, Jr., Chief, Glacier Studies Project 
[http://www.glaciers.er.usgs.gov], U.S. Geological Survey, if the Glacier Studies Project could optically scan the text and graphics, including four plates, and publish the report. It was decided that that was possible, and that the U.S. Geological Survey's Open-File Report series was the best way of making the report available to the glaciological community and the general public.

Prof. Fountain had previously worked as a field glaciologist for the U.S. Geological Survey. Publication of the Inventory of the Glaciers in the Sierra Nevada, California would provide access and a citable reference to this report. He employed Mr. Hassan Basagic, a graduate student with extensive knowledge of the glaciers in the Sierra Nevada to recompile the manuscript to make certain that all text pages, figures, and plates were included. The recompiled manuscript was sent to Richard S. Williams, Jr., for publication in the U.S. Geological Survey's Open-File Report series under the ægis of the Glacier Studies Project.

Under the national, inter-agency Federal U.S. Global Change Research Program and its successor, the U.S. Climate Change Science Program, and from the various books periodically published by the multi-national Intergovernmental Panel on Climate Change, there has been a rapidly growing interest in changes in the Earth's cryosphere [for example, glaciers, snow cover, floating ice (sea, lake, and river), and permafrost]. The recently published (2004) Arctic Climate Impact Assessment report [http://acia.uaf.edu] addresses the impact of changes in the Arctic cryosphere. Reductions in volume (and area) of the Earth's glaciers (from alpine glaciers to ice sheets) because of the meltwater contribution to sea-level rise, is a change that has global implications to the future economic and ecologic sustainability of low-lying coastal regions and islands. 
Accurate inventories of the Earth's glaciers establishes a "baseline" reference for comparison of post-baseline changes in area and volume, either positive or negative. OpenFile Report 2006-1239 is another contribution to the compilation of global glacier inventories, one of the major objectives of the World Glacier Monitoring Service headquartered in Zürich, Switzerland [http://www.geo.unizh.ch/wgms].

The participation of Andrew G. Fountain and Hassan J. Basagic was supported by the USGS Glacier Studies Project and the Western Mountain Initiative. Support was also received from NSF grant BCS-0351004, NASA grant NNGO4GJ41G.

Andrew G. Fountain

Departments of Geology and Geography

Portland State University

1721 Southwest Broadway

Portland, OR 97201 U.S.A.

e-mail: andrew@pdx.edu

URL: http:/www.glaciers.pdx.edu
Richard S. Williams, Jr.

U.S. Geological Survey

Woods Hole Science Center

384 Woods Hole Road

Woods Hole, MA 02543-1598 U.S.A.

e-mail: rswilliams@usgs.gov

URL: http://Www.glaciers.er.usgs.gov 
INVENTORY OF GLACIERS IN THE SIERRA NEVADA, CALIFORNIA by William Raub ${ }^{1}$, C. Suzanne Brown ${ }^{2}$, and Austin Post ${ }^{2}$

\section{ABSTRACT}

All perennial bodies of ice in the Sierra Nevada are listed and classified. The inventory includes 497 glaciers covering a total area of 50 square kilometers and 788 small ice bodies which do not meet the definition of a glacier, covering a total of 13 square kilometers. The listings include each ice body's drainage basin, location, orientation, altitude, area, and length the glaciers are also classified as to form, source, surface condition, and nature and activity of the terminus.

\footnotetext{
${ }^{1}$ San Jose State University, San Jose, California

${ }^{2}$ U.S. Geological Survey, Tacoma, Washington
} 
SETTING

The Sierra Nevada (fig. $1 ;$ pls. $1-4$ ) is a continuous range of high mountains extending $620 \mathrm{~km}$ from the volcanic Cascade Mountains of Washington, Oregon, and Northern California, to the Tehachapi Mountains and Mojave Desert of Southern California. The "High Sierra" is a common name for the rugged central plateau area about $40 \mathrm{~km}$ wide, which extends northward from Mt. Whitney, and definitions of its length range from $160 \mathrm{~km}$ (Wahrhaftig and Birman, 1965) to $260 \mathrm{~km}$ (Richard Ellefson, oral commun., 1974). This region was severely glaciated during the Pleistocene, leaving dozens of basins separated by a spectacular array of peaks and spires, with summits ranging from $3,900 \mathrm{~m}$ to $4,300 \mathrm{~m}$ in altitude. Serrated ridges and glacier-gouged cirques abound; hundreds of the cirques contain lakes. Here in the highest and most protected cirques are the glaciers described in this report. Major streams head in series of broad glaciated basins. Western rivers descend into spectacular valleys deeply eroded by the Pleistocene glacial advances, Yosemite and Kings Canyon are such remarkable examples that both are preserved as National Parks. Below the level of ice erosion these canyons are $V$ shaped, narrow, and crooked; they continue on to where the rugged foothills abruptly merge into the Great Central Valley of California. East of the crest, the. streams are much smaller and descend steep, glaciated valleys to the desert basins of eastern California and Nevada. 


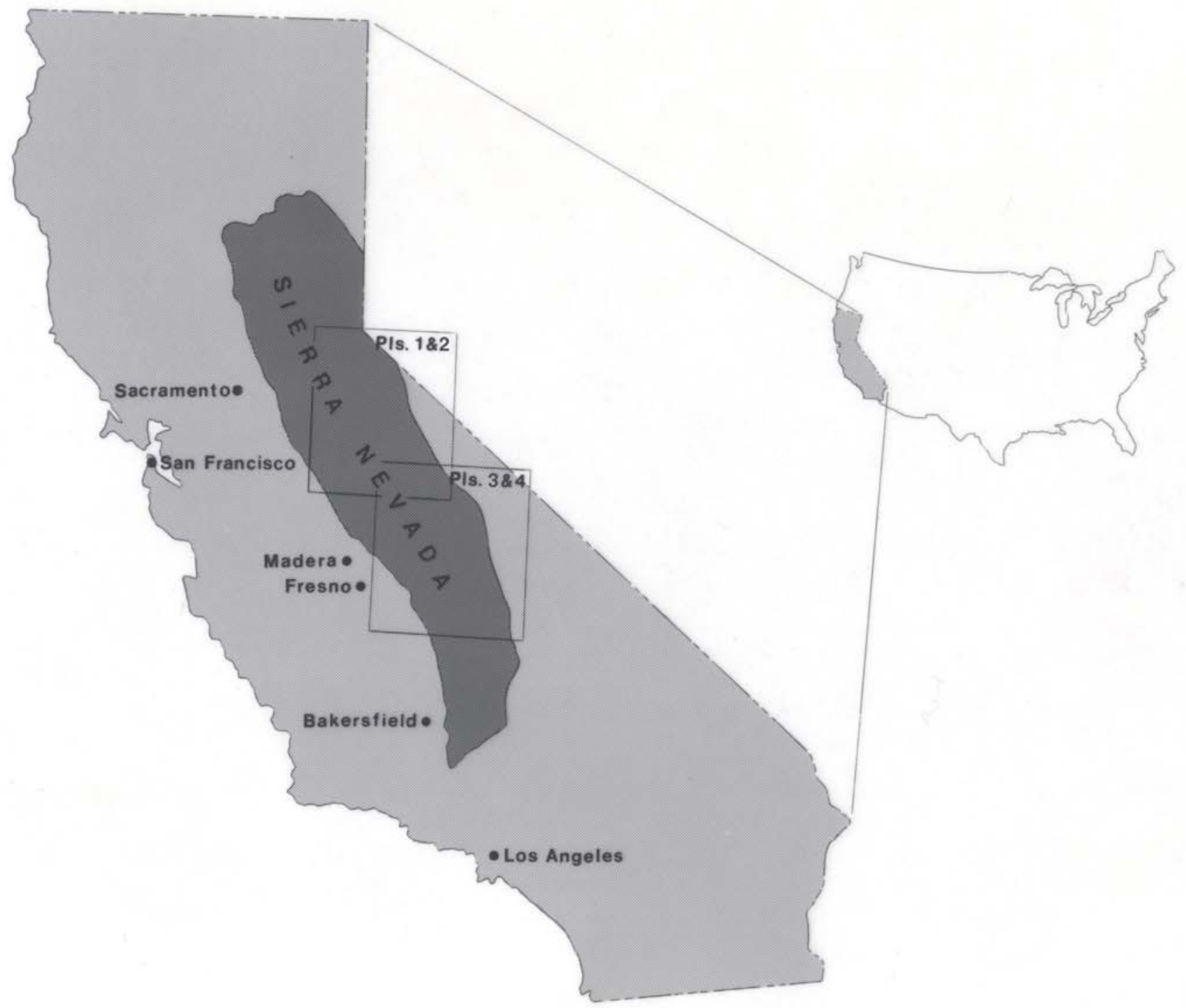

Figure 1. Orientation map of California and the Sierra Nevada. 
All the streams draining the Sierra Nevada are of great commercial importance, as practically all the water is used for irrigation, industrial, and household use. Most of the westward-draining rivers are dammed and the reservoirs provide stabilized runoff, which is used in part for power generation, city water supplies, and recreation, but primarily to irrigate the Central Valley. Practically all water from the southeastern Sierra Nevada is captured by an aqueduct and piped across the Mojave Desert to the Los Angeles basin, where it has made possible the tremendous growth of the cities there.

Much of the Sierra Nevada is forested, with climatic zones ranging from Alpine-Arctic in the high mountains to upper Sonoran in the lower foothills. In the High Sierra, scattered sub-alpine forests and open, park-like glades add greatly to the beauty of this upland area. Dense coniferous forests, predominantly of fir and pine, and superb groves of magnificent Sequoias, occupy the mid-altitudes. The finest of these groves are preserved in Sequoia, Kings Canyon, and Yosemite National Parks. The foothills of the Sierra Nevada are hot and dry on the western slopes and they are lightly forested with various species of oak. In the spring, both east and west of the Divide, and during the summer at high altitudes, wild flowers blossom in profusion, adding to the beauty of the region. 
The Sierra Nevada is a great westward-tilted fault block with a long, gentle western slope and a high, steep eastern escarpment. It is as much as $120 \mathrm{~km}$ wide in the north, narrowing to less than $80 \mathrm{~km}$ in the southernmost part, the Tehachapi Mountains. The range trends generally NNW. The highest altitude, $4421 \mathrm{~m}$, occurs at Mt. Whitney, latitude $36^{\circ} 34^{\prime} 42^{\prime \prime}$, and the general altitude level decreases gradually northward from this point.

\section{HISTORICAL OBSERVATIONS}

Prior to 1871 no glaciers of the Sierra Nevada of California had been reported. In October of that year the Black Mountain Glacier in a shadowy amphitheater on the side of Merced Peak was discovered (John Muir, 1871). Shortly after, Muir, joined in later years by Joseph LeConte, studied and sketched the Lyell and McClure Glaciers to support his theory of glaciation in the formation of Yosemite Valley's geological features.

In the $1860^{\prime} \mathrm{s}$ and $70^{\prime} \mathrm{s}$ Clarence King, while working under state geologist J. D. Whitney, explored the Kings-Kern Divide and the Mt. Brewer vicinity. Later, King described what evidently was a glacier in the Ritter Range. He went on to describe and name a glacier on Mt. Shasta after J. D. Whitney, who had convinced his field crews that no glaciers existed in the Sierra.

I. C. Russell (1897) of the U.S. Geological Survey mapped and photographed the Yosemite region glaciers in 1883. In the U.S. Geological Survey Fifth Annual Report, Russell (1885) mentions nine small glaciers, including those on Mt. Lye11, Dana Mountain, the Parker Creek group, Mt. Gibbs, and Mt. Conness . He published a map and photograph of the Mt. Lyell glaciers in the Eighth Annual Report' (Russel1, 1889) and explained that those glaciers were not remnants of 
the Pleistocene glaciers, but that they had reformed after the earlier glaciers had completely disappeared. A. C. Lawson (1904) further discussed glaciers in the Sierra in his paper on "The Geomorphology of the Upper Kern Basin."

Modern study of the glacial history of the Sierra Nevada was begun in 1930 by Matthes (1930) and Blackwelder (1931). In 1939 the American Geophysical Union Committee on Glaciers, headed by Matthes, was working on Sierra glaciers in the Yosemite region when they witnessed a lake behind the Mt. Conness Glacier moraine front break through, exposing the banded ice core of the rock-mantled terminal moraine so common on Sierra glaciers. This observation suggested that ice cores were present throughout the Sierra on similar glaciers (Matthes, 1940). Matthes considered the possibility of glaciers south to $37^{\circ} 60^{\prime} 30^{\prime \prime}$, and the existence of very small glaciers at this latitude was confirmed by W. Raub in 1971.

Raub also observed glaciers in the Kaweah Peaks in 1938. Yosemite National Park naturalists have made periodic observations since 1931 and periodic surveys since the $1950^{\prime}$ s on the park glaciers. The American Alpine Club (AAC) and Sierra Club have also been active in examining California glaciers. In 1946 the AAC mapped the Palisade Glacier (Heald, 1947). The Sierra Club bulletins also contain several excellent articles on the Sierra Nevada glaciers (Adams, 1932; Farquhar, 1920; Gilbert, 1904; Harrison, 1950 and 1951; Matthes, 1948).

\section{PLEISTOCENE GLACIATION}

There is evidence glaciers began forming in the Sierra Nevada between 2.7 and 3 million years ago. There were also major Pleistocene glacial advances about 750,000 years B.P. (before present), about 400,000 years B.P., again about 130,000 years B.P., and several advances from 60,000-20,000 years B.P. (Birkeland, and others, 1971; Hill, 1975, p. 145). 
During these glaciations, ice sheets covered much of Canada and northeastern North America, and in the west they covered parts of northern Washington, Idaho, and Montana. Other ranges, such as the middle and southern Cascades and most of the Rocky Mountains, contained ice fields and valley glaciers separate from the continental ice sheets. At the height of glaciation, the Sierra Nevada bore a mountain icefield $435 \mathrm{~km}$ long and 32-50 km wide (Wahrhaftig and Birman, 1966, p. 158) (fig. 2). It consisted mainly of a series of ice-filled basins from which valley glaciers descended east and west. The steep glaciers on the east side generally filled their outlet. valleys to a thickness of about $300 \mathrm{~m}$ on the west, ice flowing into the narrow canyons of the major rivers filled them to greater depths (Wahrhaftig and Birman, 1966, p. 161).

Moraines from the advances of $60,000-20,000$ B.P. are particularly well developed on the eastern slope of the Sierra. The glaciers did not spread as piedmont lobes, but maintained about the same widths they had in their mountain canyons, being enclosed by sharp-crested lateral moraines several hundred meters high. Noteworthy examples of these classic lateral and terminal moraines are present along many streams such as Green, Virginia, Mill, Leevining, and Walker Creeks. "Many of these morainal ridges have double or triple crests, with narrow trenches running the length of the ridge between the crests, indicating two or three advances of the ice during their construction" (Wahrhaftig and Birman, 1966, p. 161). Little Walker Lake above Mono Lake, for example, is enclosed by moraines deposited by three glacier advances (Hi11, 1975, p. 146; Sharp and Birman, 1963). 

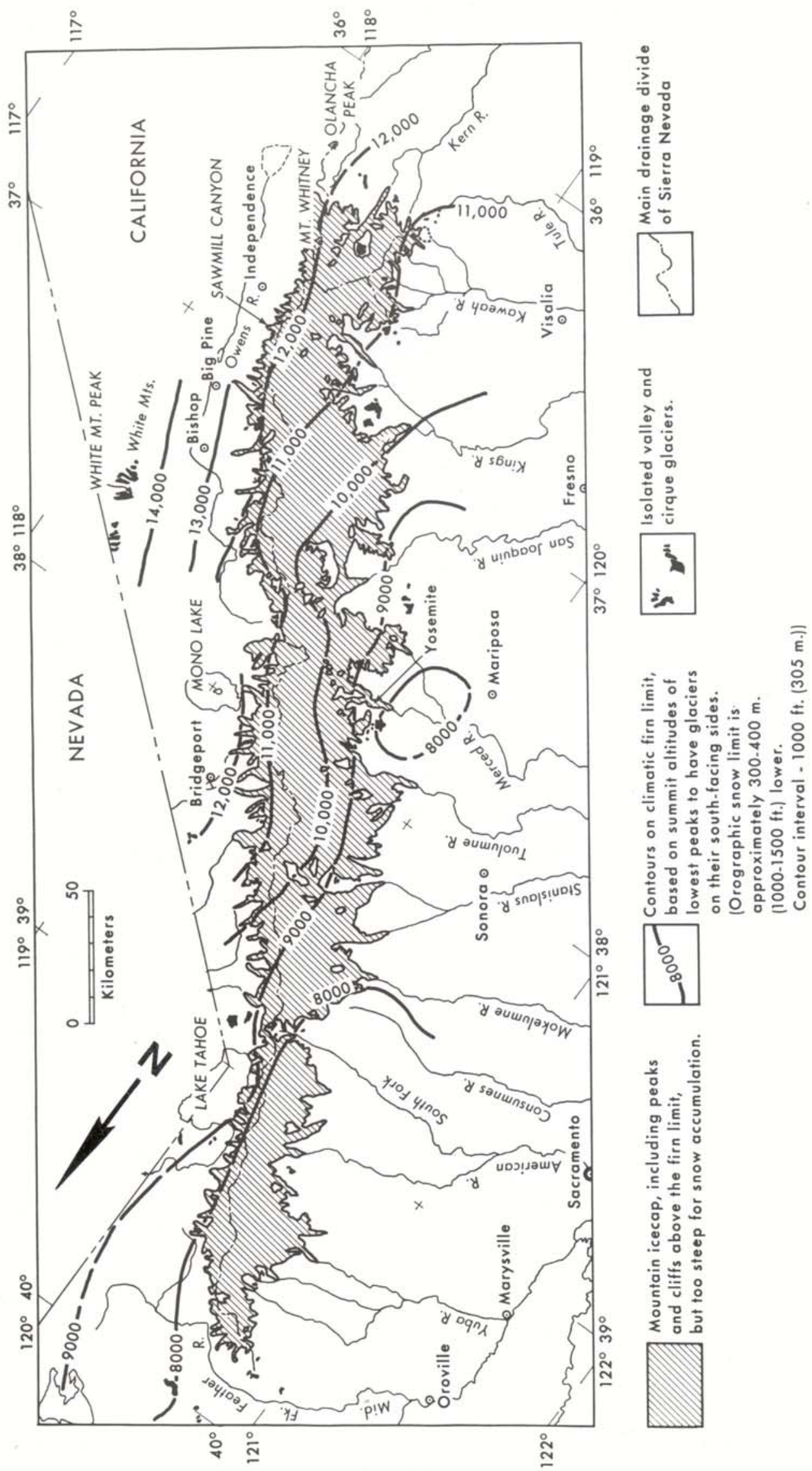

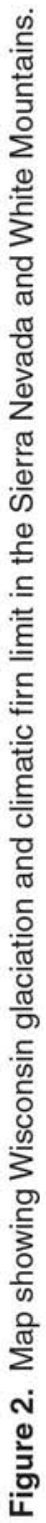


During the last 6,000 years of the Holocene, now called the Neoglacial (Denton and Porter, 1967), climatic conditions have been favorable for glaciers to form several times in various parts of the world. There have been three glaciations in the Sierra Nevada (Burke and Birkeland, 1983), during which time there was extensive glacial and rock-glacial activity.

Present-day glaciers, although occupying cirques carved by the Pleistocene glaciers, were formed during the most recent glaciation, the Matthes, named after Francois Matthes. This glaciation began about 500 years ago, with the glaciers reaching maximum size about 1700-1750. Immediately after 1750 the glaciers retreated somewhat conditions favoring glacier growth again resulted in slight advances until the turn of this century. The ice then began to thin, with general rapid retreat of glaciers from their terminal moraines taking place, particularly in the 1930's. Farquhar (1920) first noticed thinning of Lyell Glacier ( $\$$ 非 $4351,2^{1}, \mathrm{p} 1.2$ ) in 1919. From reports of Assistant Park Naturalist M. E. Beatty, East Lye11 (非4435 1, p1. 2) lost almost twice as much volume in the three-year period $1936-39$ as in the three-year period 1933-36 (Matthes, 1940). Mt. Conness Glacier ( $\$$ ) 4223 15, p1. 2) once a very active glacier a hundred meters or more thick (Matthes, 1948), retreated $30 \mathrm{~m}$ in 1936-37 and 14 m between 1937 and 1939 (Matthes, 1940) and was "disappearing most rapidly" in 1949 (Harrison, 1950).

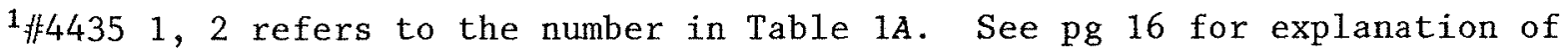
the numbering system. 
During the $1940^{\prime} \mathrm{s}$ a few of the glaciers actually increased in thickness and, although the termini continued to recede, the drastic glacier recession experienced during the $1930^{\prime} \mathrm{s}$ appeared to be slowing down. Harrison (1951) reported a thickness increase between 1937 and 1949 of 8 m near the icefall on Lyell Glacier, and approximately $7 \mathrm{~m}$ under a cliff at the east end of the glacier a rock shoulder exposed in a 1937 photograph was completely covered in a 1953 photograph (Harrison, 1950, 1951, 1956). He also reported (Harrison, 1951) an increase in the thickness of Dana Glacier (非223 6, p1. 2) between 1940 and 1949 and Heald (1947) reported that Palisade Glacier (非4214 11, pl. 4) had increased in thickness in 1946.

This period of thickening, however, was short-lived Meier and Post (1962) reported that most of the Sierra Nevada glaciers experienced strongly negative net budgets in the late $1950^{\prime} \mathrm{s}$, and this rapid decline continued into the $1960^{\prime}$ s. The heavy-precipitation winters of 1966-67, 1968-69, and 1972-73 resulted in a temporary increase in the size of many Sierra glaciers. In 1975, the National Park Service at Yosemite reported that the rapid decline of the 1960's had slowed and the glaciers were about the same size in 1975 as in 1970, with some showing a slight increase in the upper regions and a decreased thickness in the middle and terminus regions (National Park Service, 1976). Between 1975 and 1980 periods of severe drought (1976 and 1977) and record precipitation (1978 and 1980) have resulted in both extremes in ice loss and rapid recovery of Sierra Nevada glaciers. Thus, no generalizations of either a present thickening or a thinning trend may be made. 


\section{PRESENT GLACIERS}

Most of the present-day glaciers in the Sierra Nevada are small cirque glaciers, ice in niches, or in perched clefts, scattered widely from near Lake Tahoe in the north to just south of Mount Whitney and the great Western Divide (pls. 1-4). Even glaciers less than $0.01 \mathrm{~km}^{2}$ in area may show a bergschrund, a high steep front, or crevasses, and outlet streams contain fine suspended sediment, demonstrating glacier flow. Many glaciers have exposed ice in the upper portions with heavily debris-covered termini. These debris-covered termini are often very high and unusually large for the size of the glacier occasionally the slope of these fronts exceed $45^{\circ}-60^{\circ}$.

Besides the small alpine glaciers, the Sierra has many rock glaciers. These rock glaciers evidently formed in early Neoglacial time when the onset of conditions favoring glacier growth caused ice to form in massive rock deposits formed by mass wasting in Pleistocene cirques. As ice accumulated, these deposits began to flow and many still continue to do so. The present alpine glaciers also formed in the highest of these cirques many of the present glaciers are in part glacier ice and in part rock glaciers. In some places, the clear ice and debris-covered ice are no longer in contact, the latter consisting of massive arcuate ice-cored moraines or series of looped moraines. 


\section{GLACIER DISTRIBUTION}

The Sierra Nevada to the north of Sonora Pass is generally lower in altitude than that to the south, but greater snowfall causes some small glaciers to exist at these much lower altitudes, such as in the Crystal Range (pls. 1 and 2). Farther south, somewhat larger glaciers are found at the head of the Lyell Fork of the Tuolumne River and at the head of Robinson Creek (pls. 1 and 2). Medium to large $\left(0.6-1.0 \mathrm{~km}^{2}\right)$ glaciers abound at the head of Bishop Creek, the South Fork San Joaquin River, Pine Creek, and the Middle Fork Kings River (p1s. 3 and 4). The Palisade Glacier at the head of Big Pine Creek is the largest in the Sierra, with an area of $1.6 \mathrm{~km}^{2}$. Clusters of small glaciers, situated mainly at the base of protective headwalls, are found along the northern Great Western Divide, on the north side of the Kings-Kern Divide, and on the Kaweah Peaks at the headwaters of the Kern-Kaweah River. The most southerly group of glaciers is in the Mt. Whitney region, extending south to Mt. Pickering (Kehrlein, 1950). 
On August 23 and 24, 1972, during a period of severe drought, with a minimum of snow cover on the glaciers, the U.S. Geological Survey made a detailed glacier photography flight which covered the entire Sierra Nevada. This inventory is compiled from data collected on that flight. All glaciers and ice patches plus many ice-cored rock glaciers are included. The glaciers and ice patches, after being identified on the vertical and oblique photographs, were outlined on 1:62,500 scale U.S. Geological Survey topographic quadrangles and inventoried by William Raub, assisted by George Curtis.

For this study, a glacier is defined as any perennial ice exhibiting one or more of the following: (1) snow and/or ice accumulated over several years, (2) a bergschrund or crevasses, (3) heavily debris-covered ice which exhibits evidence of flow, and (4) moraines and trim lines. The minimum size mapped in this survey is $0.01 \mathrm{~km}^{2}$. Included are (1) active glaciers, (2) perennial ice patches derived from direct snow accumulation, wind drift, or snow avalanches, (3) relict ice from former active glaciers, and (4) rock glaciers. 
This report has been compiled using data derived from approximately 300 vertical and oblique aerial photographs. USDA Forest Service aerial photos aided in some terminus mapping. This information was augmented by many personal observations by Raub. The glaciers' and ice patches' geographic coordinates, altitudes at the headwall and terminus, and area were recorded. Due to the small size of most of the glaciers and the relatively large contour interval ( $80 \mathrm{ft}$ ) on the maps, some altitudes are accurate only to within 10 to $15 \mathrm{~m}$. Each glacier was classified as to type, source, surface condition, nature of the terminus, and orientation the standard glacier-inventory guide recommended by the International Commission on Snow and Ice (UNESCO/IASH, 1970) was used, but modified to better describe the many tiny Sierra Nevada glaciers. The tabulation scheme and computer compilation program were designed for all types of glaciers occurring in the United States thus, not all the categories have been used in this particular study. Appendix 1 gives a brief description of all items tabulated in the inventory. 
18 Inventory of Glaciers in the Sierra Nevada, California

\section{LIST OF GLACIERS}

The resulting glacier tabulation is shown in table $1 A$, and the ice patch tabulation in table $1 B$, unless otherwise noted in the explanation, any missing values indicate the data were not available. 


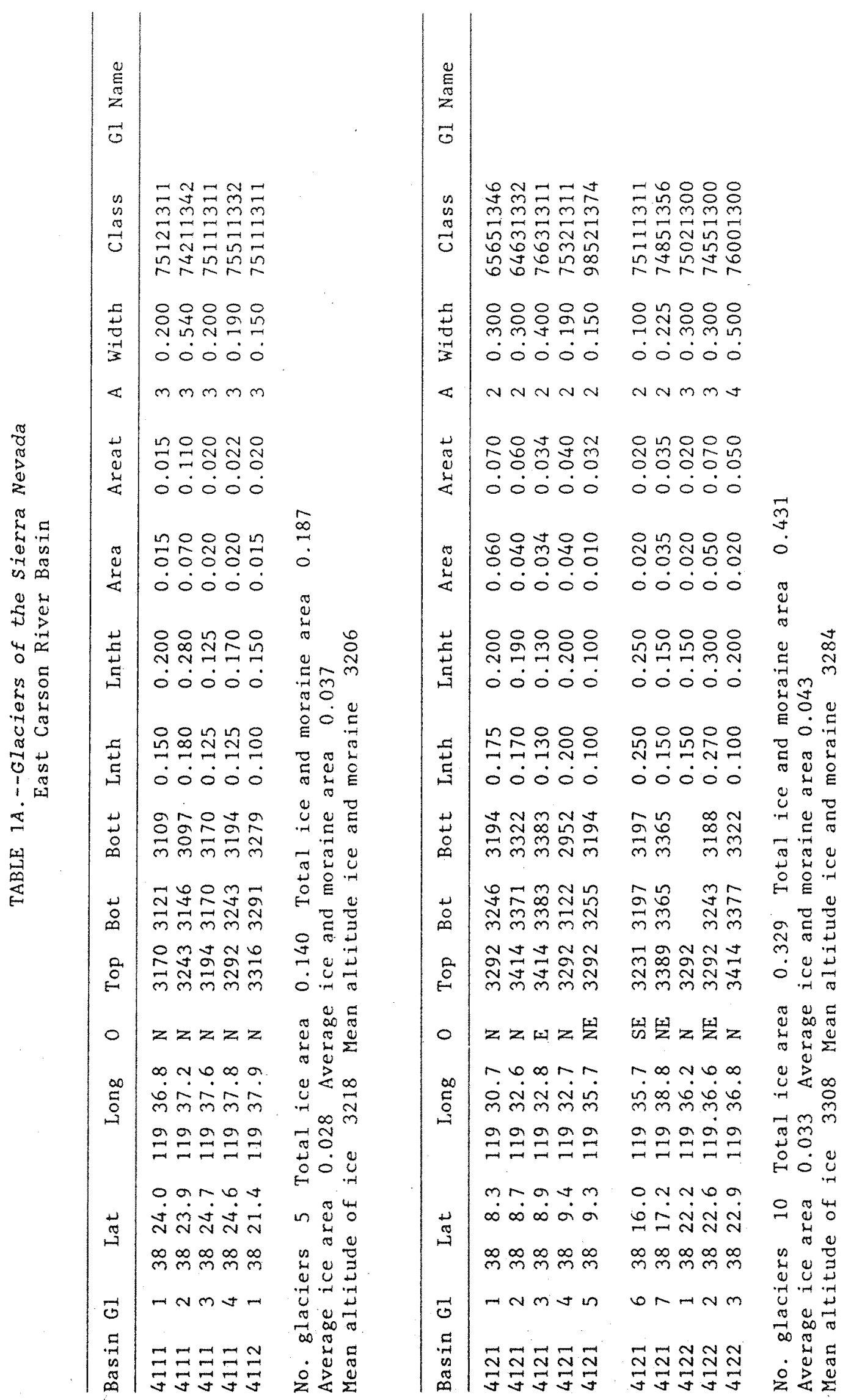




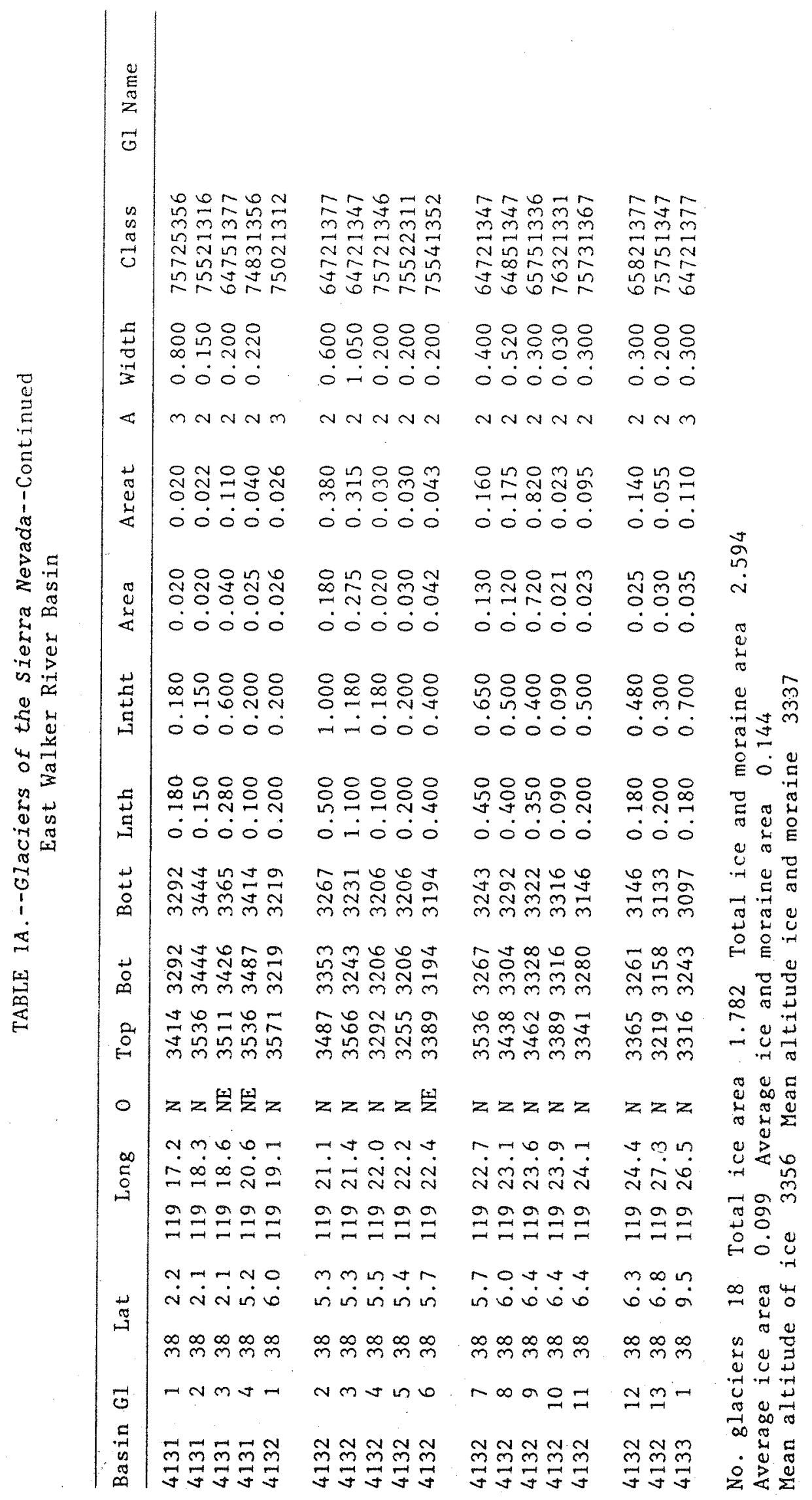




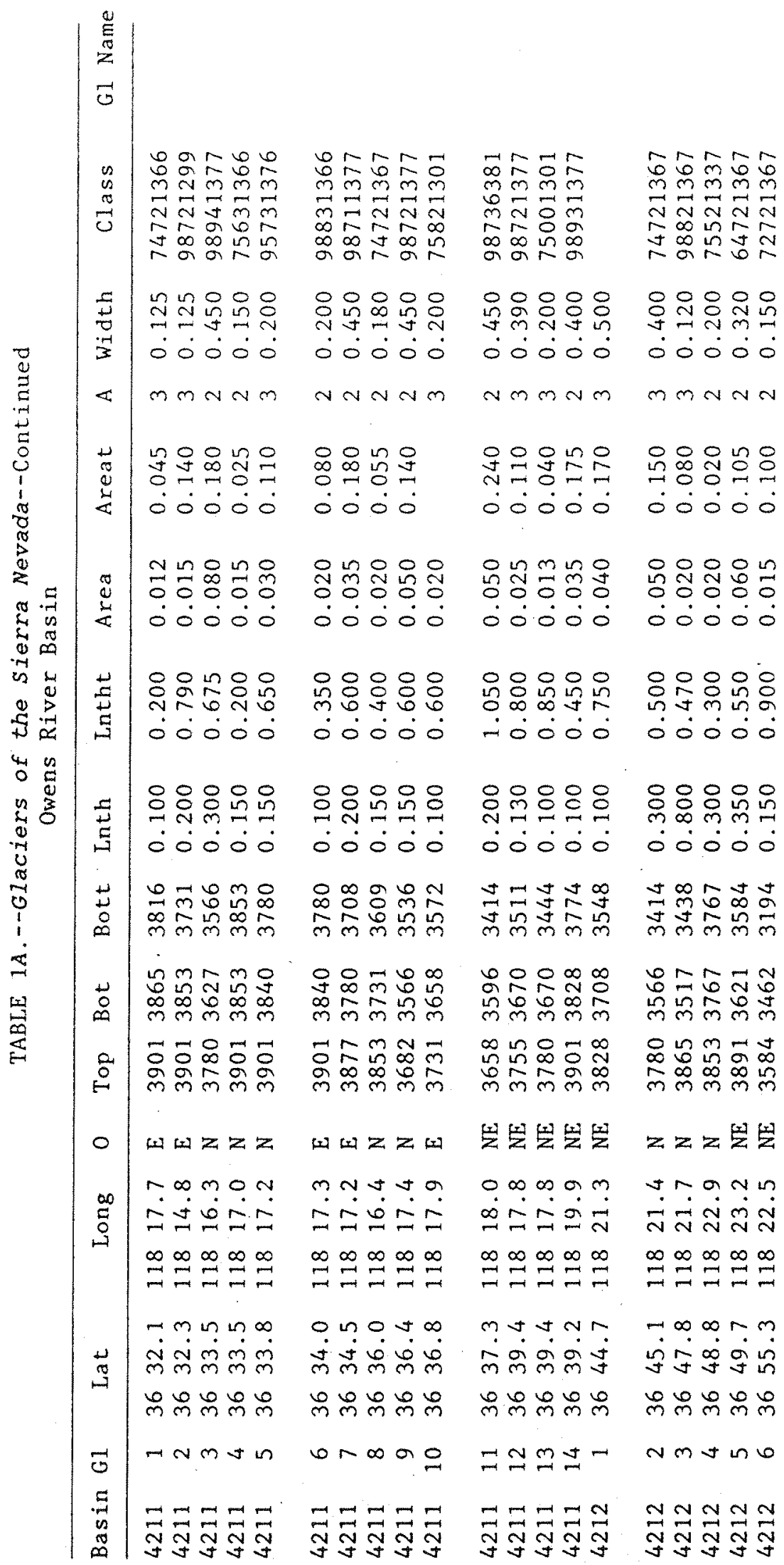




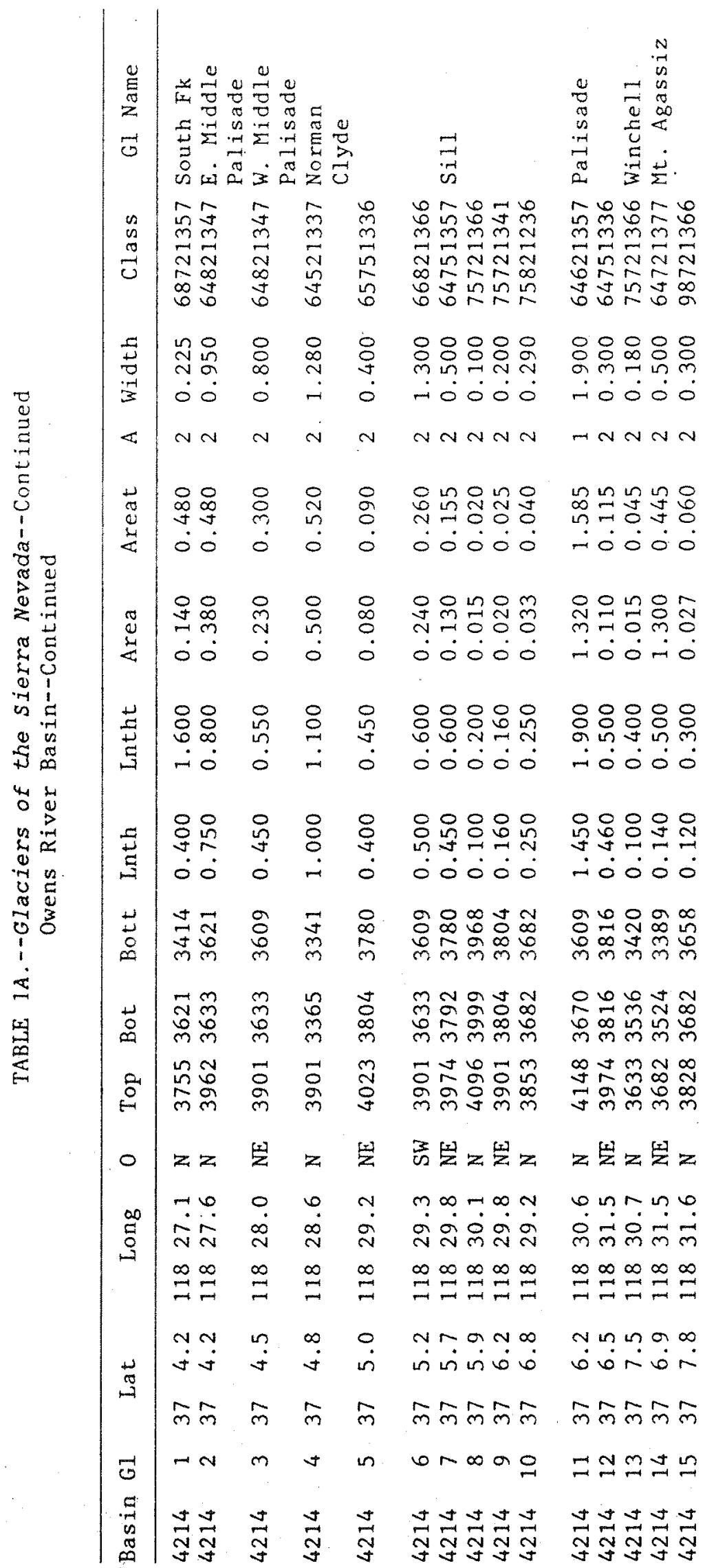




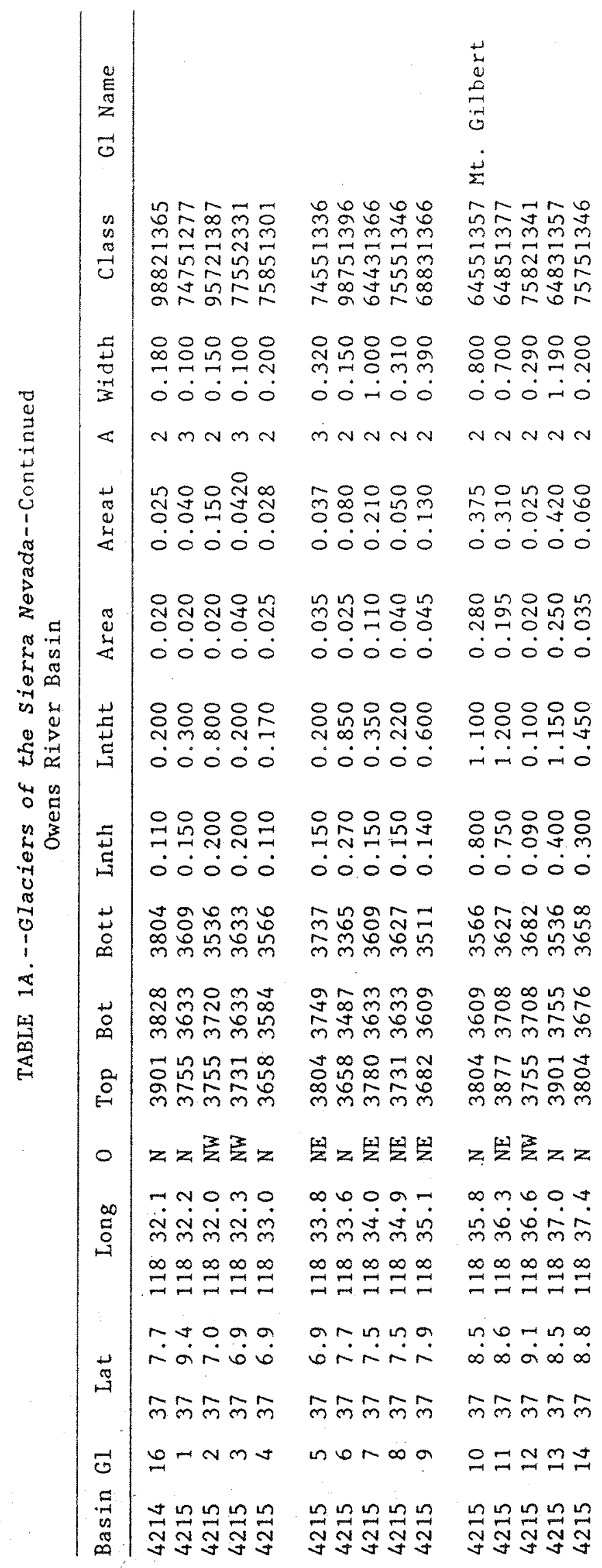




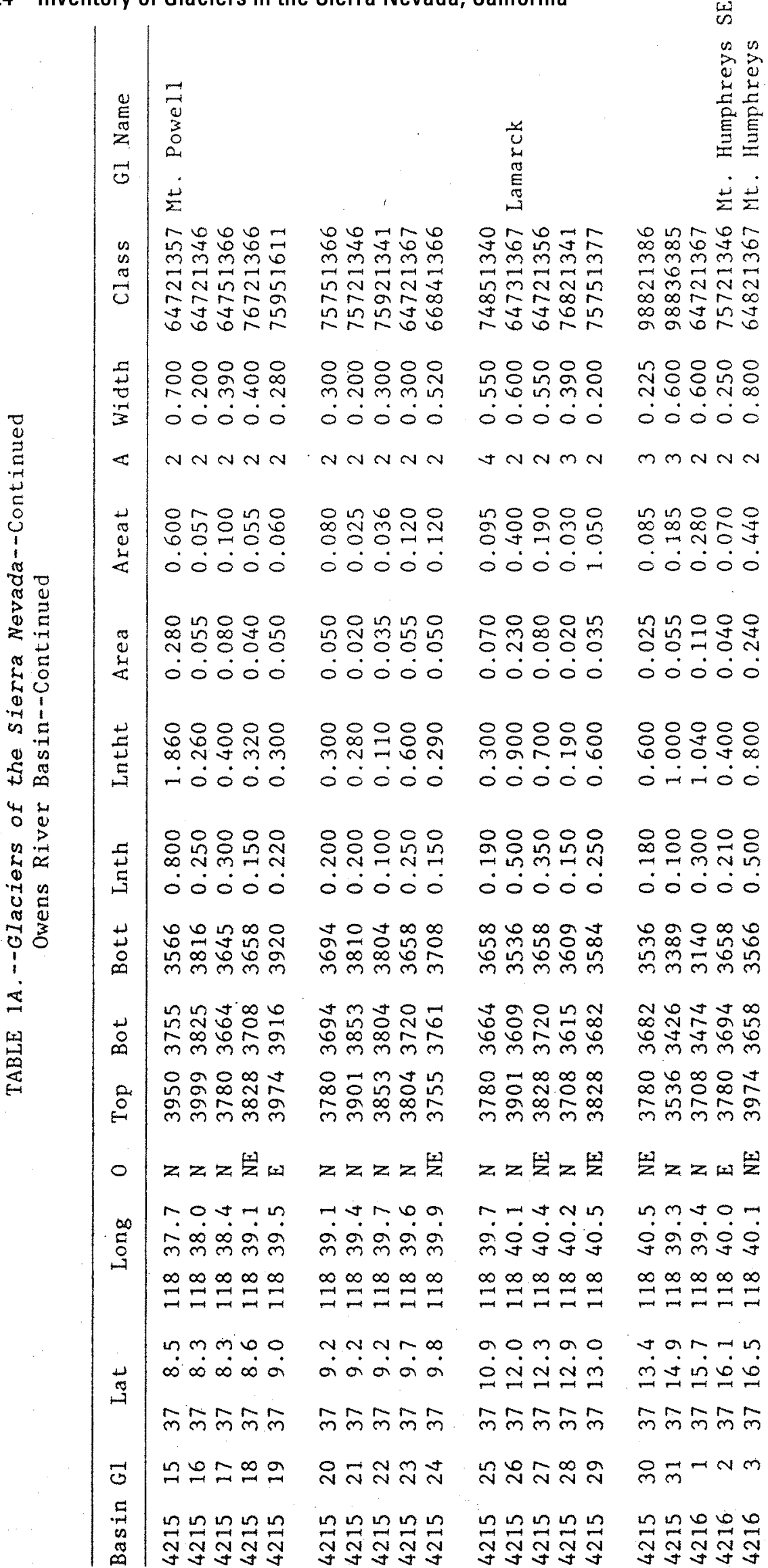




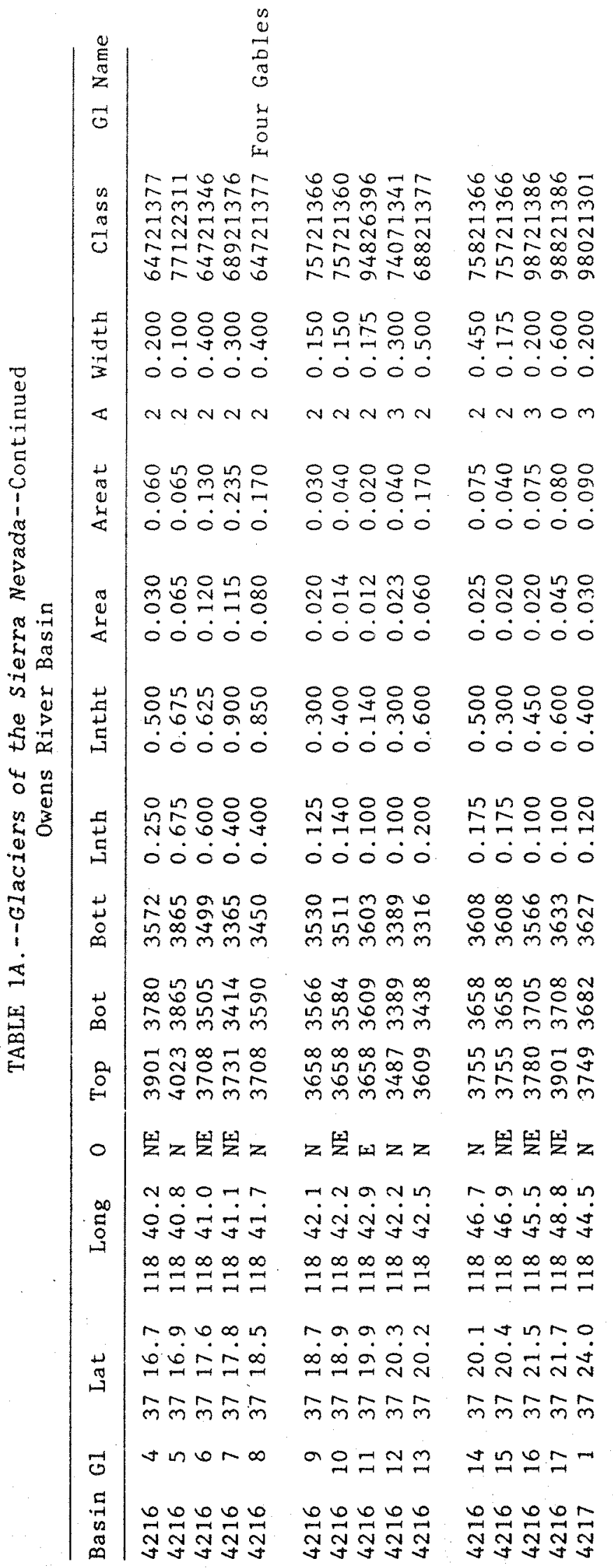




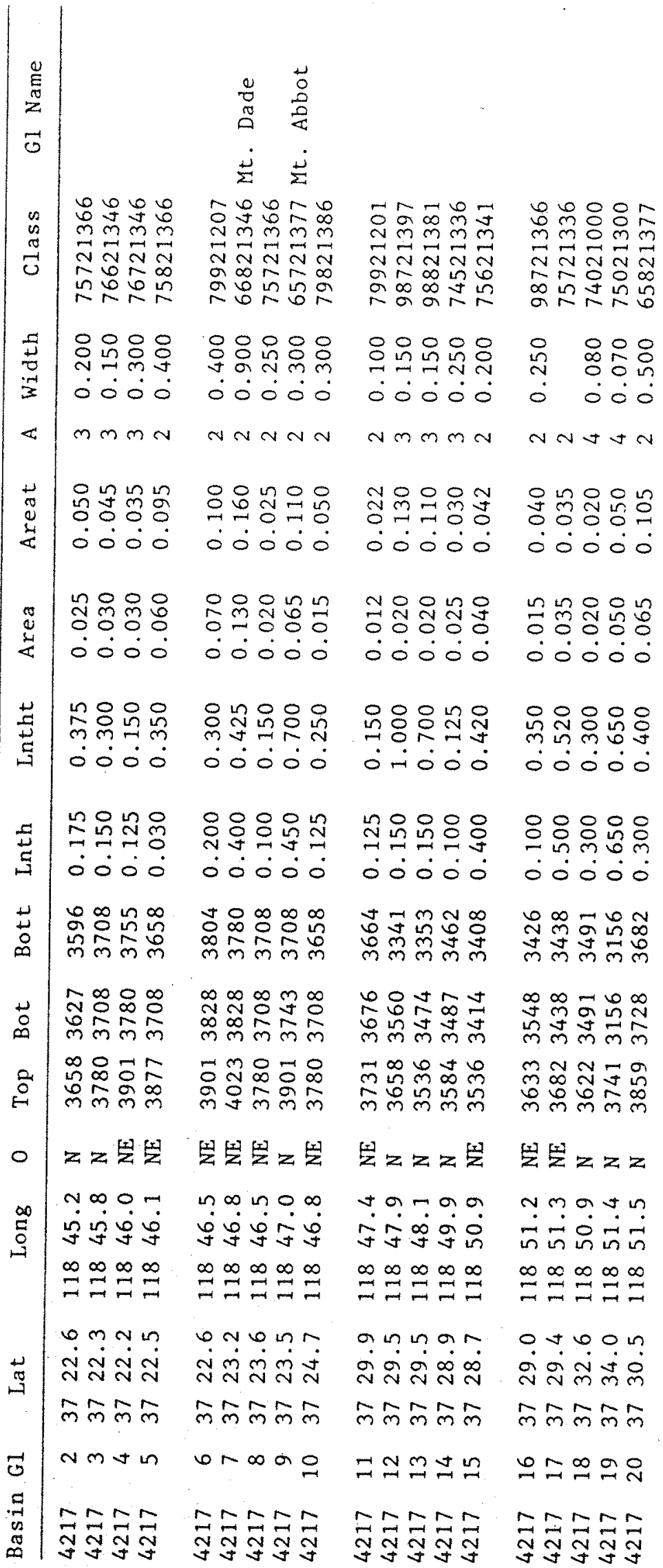




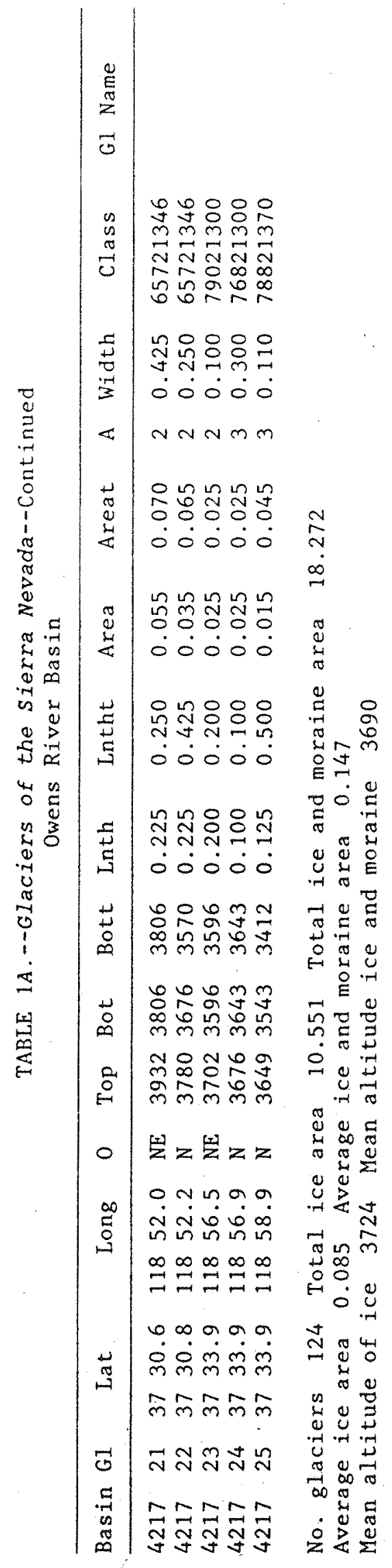




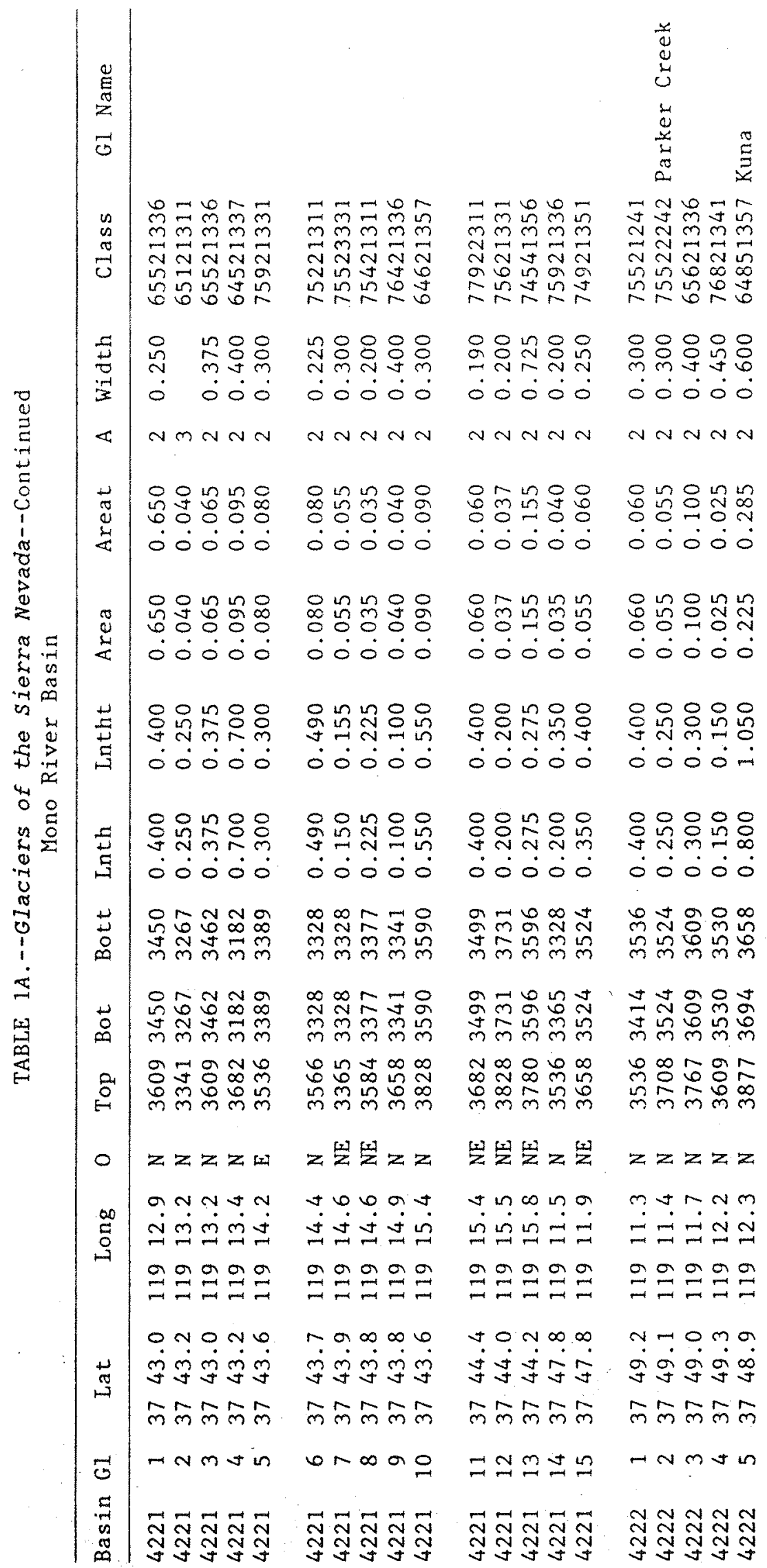




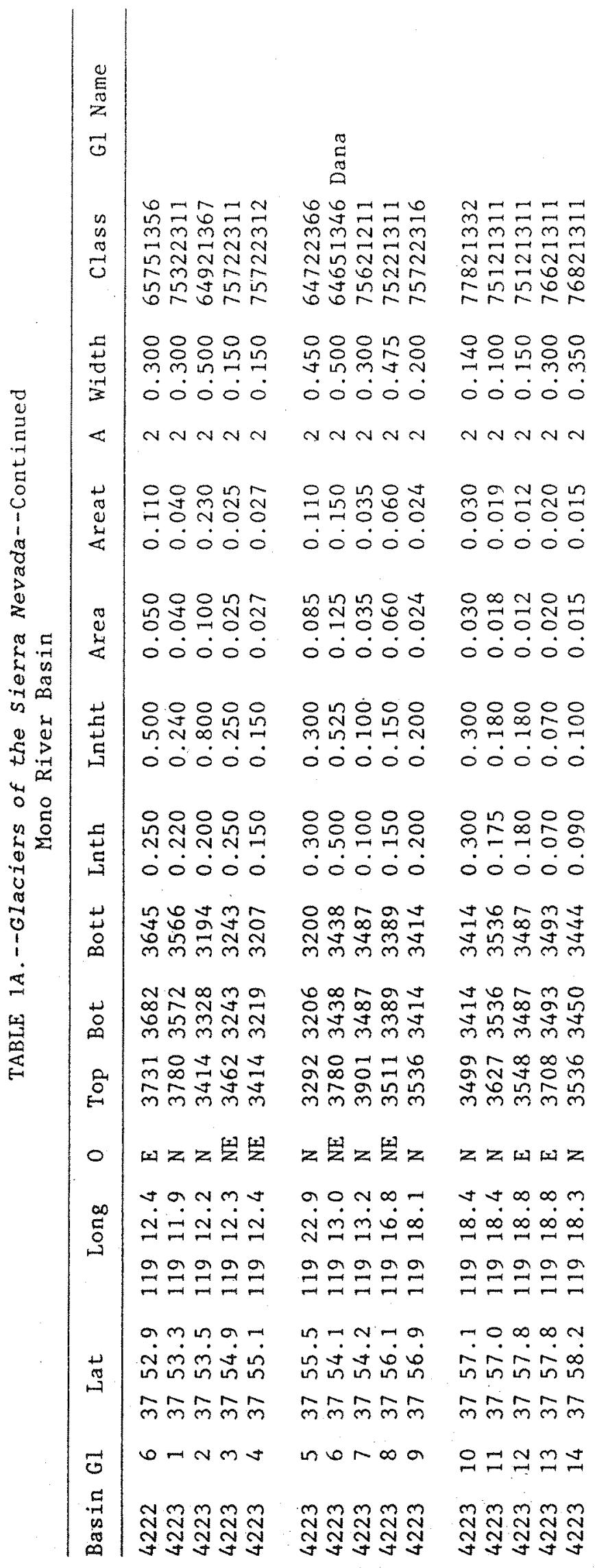




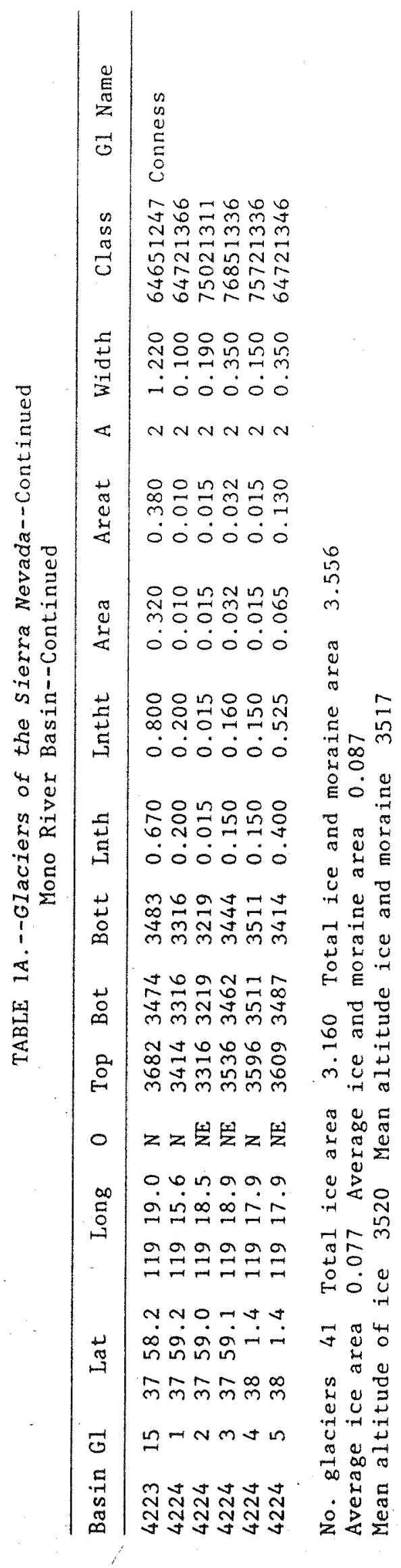




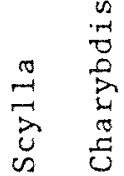

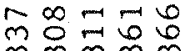

mल ले m

तैत्रत्रत ing oñ nin

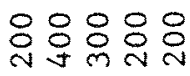
○ं $0 \dot{0} 0$

$\cot n d$

mกำ 0000:

ํㅠㅇํㅇㅇㅠ

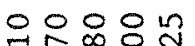

mㅇํㅇำ

00000

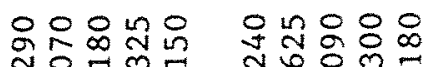

กิํำ

00000

ชู워

०0:00:

$m \infty \infty$

ㅇํำ

있어은웅유

mit.

०0ं0.

융요ㅇㅛㅛ용

○ं0 00

융용용

$\therefore \dot{0} \dot{0} 0$

जे ज़ लै

Nㅗㅇㅛ

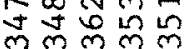

잉 in

$00 N N \underset{N}{0}$

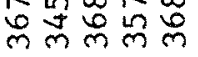

$\infty 0_{0}^{\infty} \pi$ n

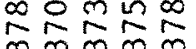

$m \mathrm{~m} m$

$m m m m$

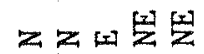

贸zzz

$\checkmark-\infty \sim \infty$

$\because \infty r ?$

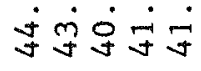

$\infty \infty \infty \infty \infty$

$=\exists=0$

$\infty \infty \infty \infty \infty$

$\stackrel{\infty}{=} \underset{-}{=}=$

- न न न न

oตm ตn

noms n

于ं

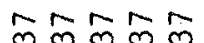

लำกलm

$\mathrm{mmmm}$

$M \pi N m$

$\ln \infty+\infty$ $\therefore 000$

o $+\infty \circ \mathrm{m}$

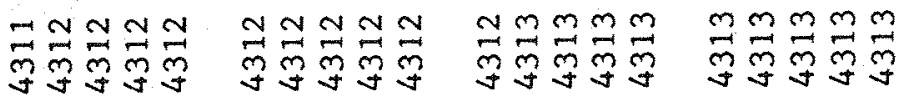

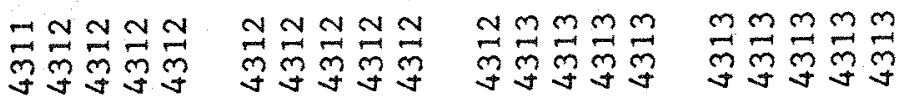

"⿹丁口

mलm

그류

in $\pi N$

in 0 is

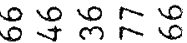

mmmm

तै $\vec{n}$ in

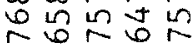

을ㅇㅇㅇㅇㅝ 00000 00000

$m N N N$

NNmNN

ㄱํํํํำ

00000 $\dot{0} 0000$

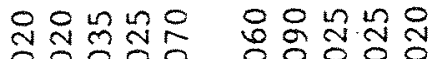
வ0் $\dot{0} \dot{0} \dot{0} \dot{0} \dot{0} 0 \dot{0}$

용ㅇㅇㅇㅇㅇㅇㅇㅇㅇㅇㅇㅇㅇ -

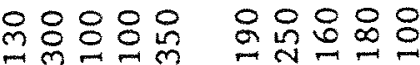
0ல0ல0 00000

$\infty$ ษ

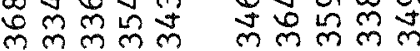

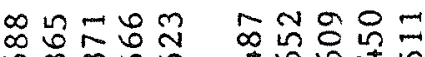

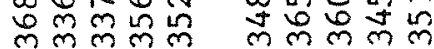

थ

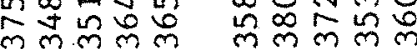

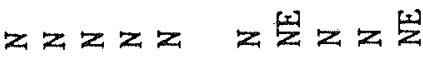

in 6 n $n$ a 0 n

n̄m

$\infty \infty \infty \infty \infty \quad \infty \infty \infty \infty$

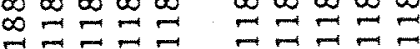

ดกแกแ mงm?

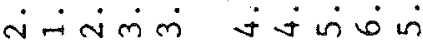

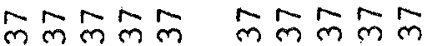

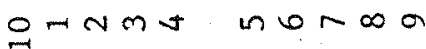




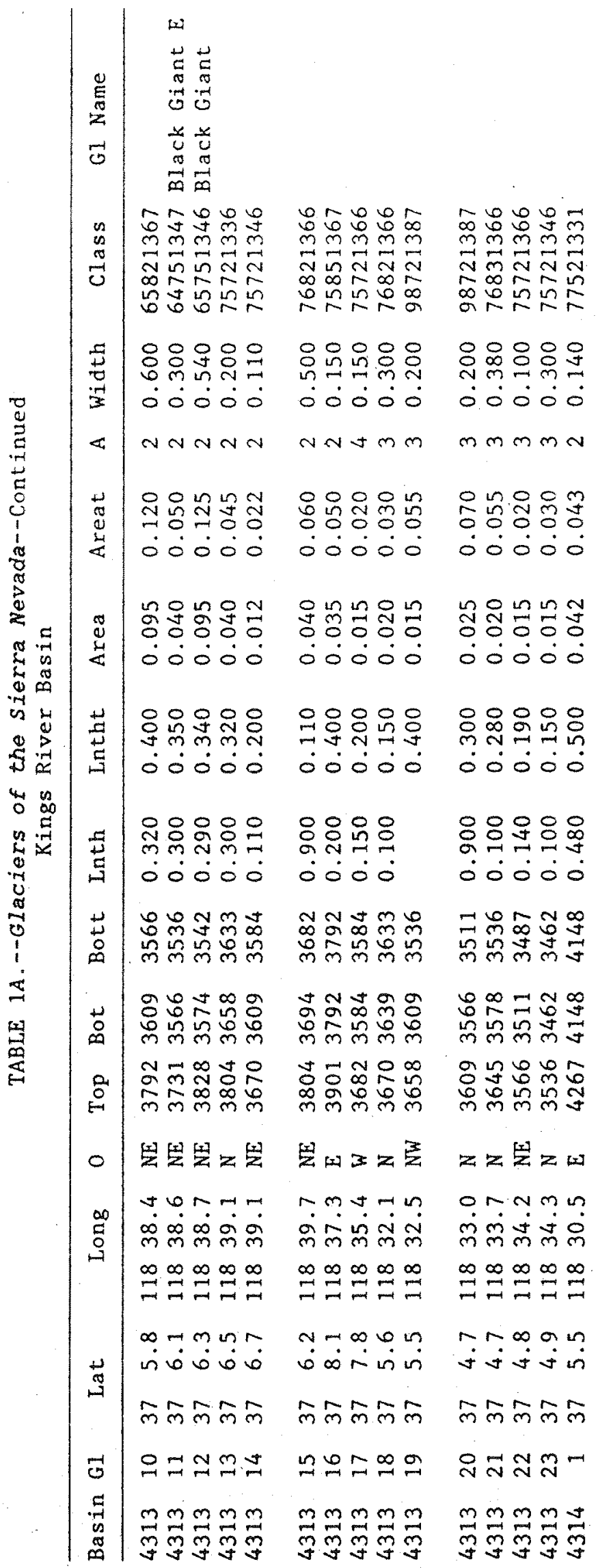




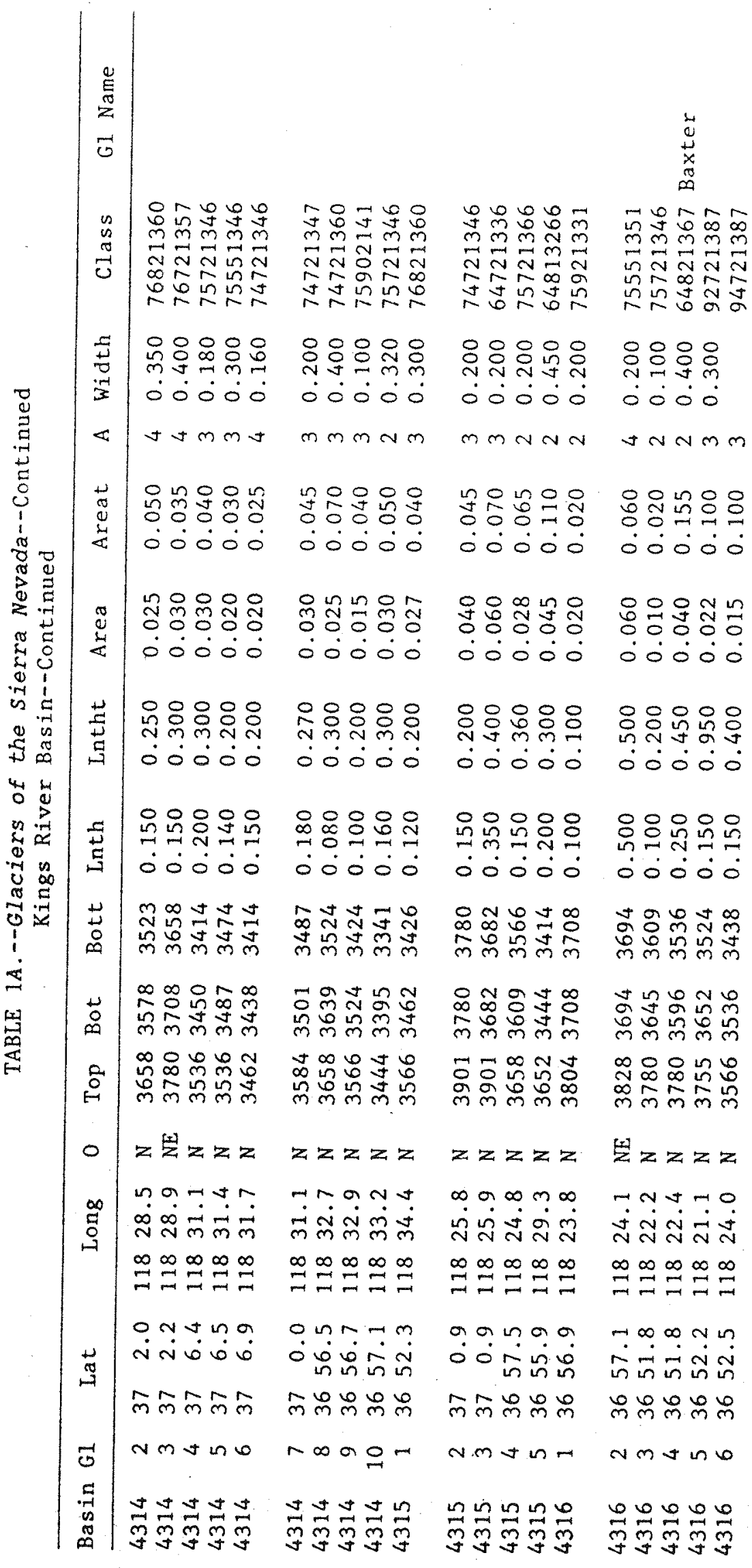




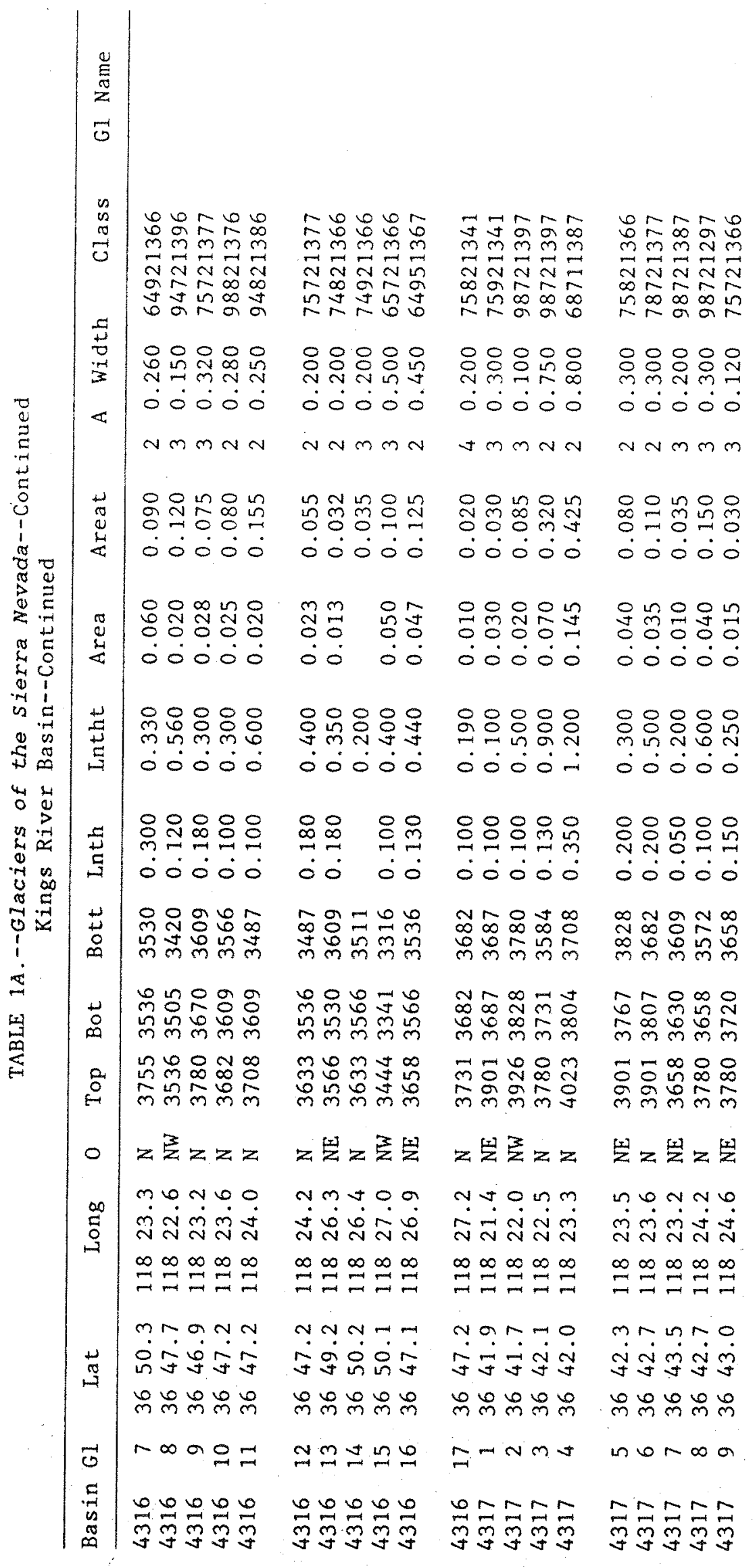


도ำธี के กีतี तี $\operatorname{TrN}$

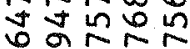

을응용요 앙융유ㅇㅛㅠ 00000 00000 Nmm N

NNNNN 믐융ํํ용 प0

융융융음 0000

ㅇํㅇ ิํㅇํํㅇํㅠ 0ं0்:0

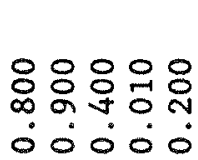
은응융유유 $\circ 0000$ g $\pm \vec{m}$ $\therefore \pm \vec{m}$

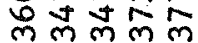

음요 กิ

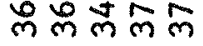

$00 \infty 0$ m

GNor ले ले ल जै ज्ञ $\vec{N}$ NT क 능 00000

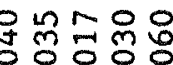
00000 $\therefore 0000$

응요용ㅇㅇㅇㅇㅇ ○0்00

응엄윤온용 வ0் $0 \dot{0}$

응용요용요 000ं

NNMN

육 ํํㅇํํㅇำ $\therefore 000$

능요용 00000 ○ं $0 \dot{0} 0$

ง

동

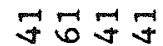

ले ले

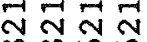

$\infty \infty 60$

少员员

응용ㅇㅇㅇㅛ

$\therefore 000$

$m m n$

응용융

0ं0ं

$\begin{array}{lll} & & m \\ 0 & 0 & n \\ 0 & 0 & m\end{array}$

ن.

0000

응응윤운 ○०००

응윢윰융 ○ं 000

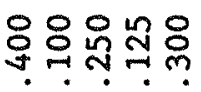
ல0்0ல

은ำ

ホ。

लूल लू

응ำ

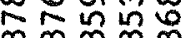

लm

늉유용

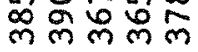

$z z z z$

出兒眊

$6 \mathrm{man}$

ปี่

$\infty \infty \infty \infty \infty$

$=\infty=\infty$

o o $\mathrm{Jm}$

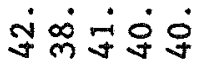

ํํํำ ํำ

N $⿻ \infty$ $\stackrel{\infty}{\sim} \stackrel{\infty}{\sim} \stackrel{\sim}{\sim} \stackrel{\infty}{N}$

$\infty \infty \infty \infty \infty$

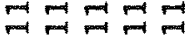

N $N=\infty$

in 6 in

nू ल m

ก $\infty$ \%

ले m ले

- $60 \% m$

लॉल

옥용유용 வ 000

$\checkmark$ ㄴํㅇ

लึ

웅ㅈㅇㅇㅇㅇ

ले ले फे

$\infty a \infty N$

승ํㅇ

ल

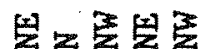

a $N$ นก $\infty$

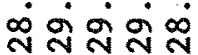

$\infty \infty \infty \infty \infty$

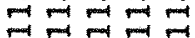

$N m m+m$ 여ㅇㅝㅝ

○ю0\%

m $n$ HO

in

I $3 \pm$

如专

$+0 \mathrm{~mm}$

लिख लि

$\infty \infty \infty$

페 $=$

a

$\dot{0}$

ल

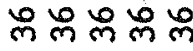

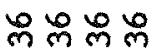

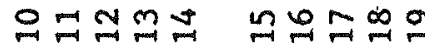

듬드

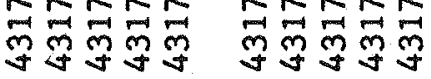

온ำู

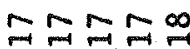

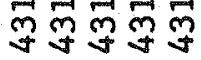

NM

$\infty \infty \infty$

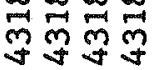



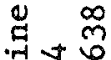

学向

응.

ह 0 .

๑ 4

过

$-10$

त

0 告

$m$ 뭉

$\infty$ a

is

का

:

440

$y ?$

in

ำ

* 0.

ने के

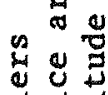

ن त $\infty$

$\infty$

- ब

$\circ \stackrel{9}{2}$ 


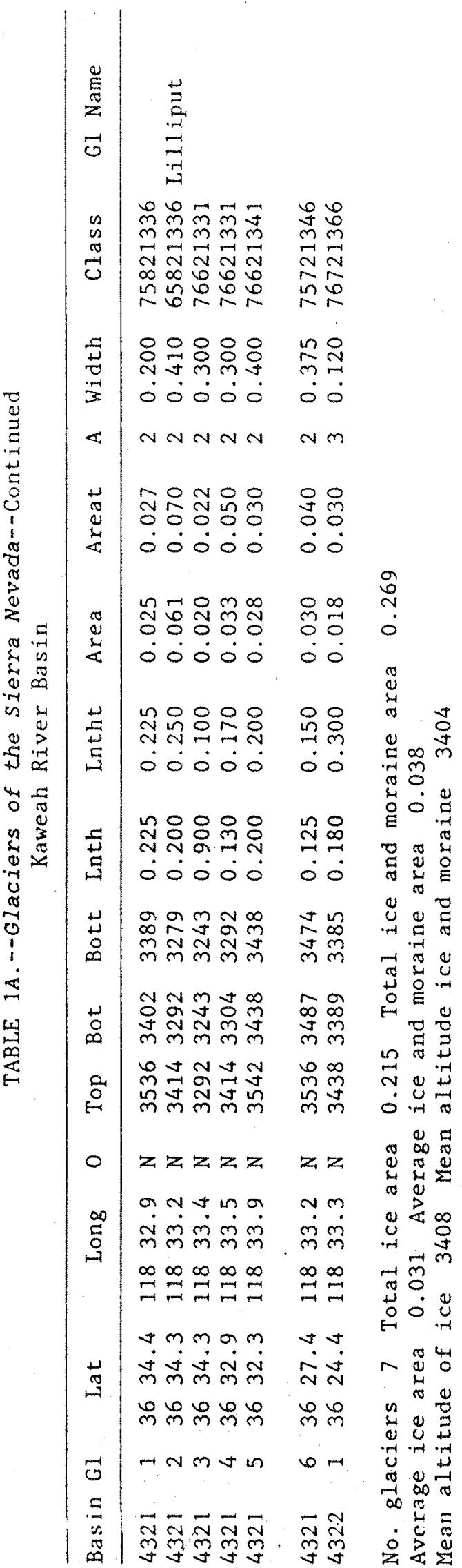




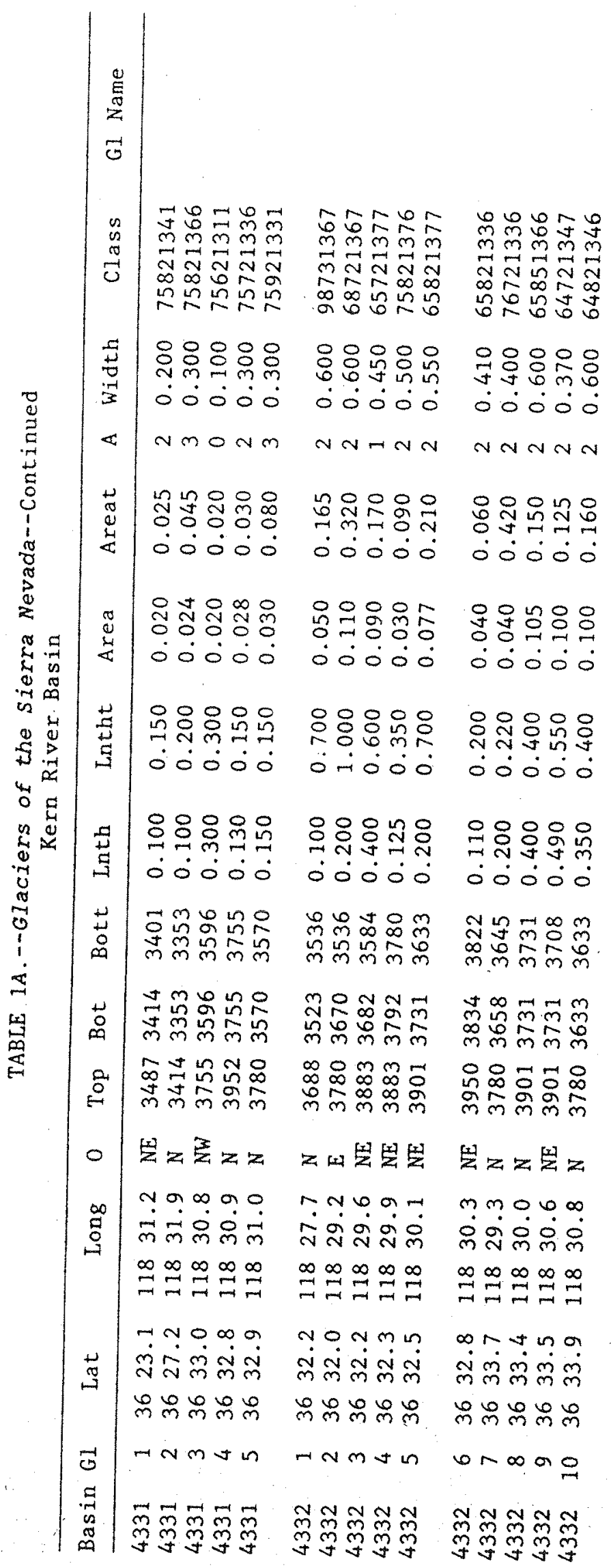




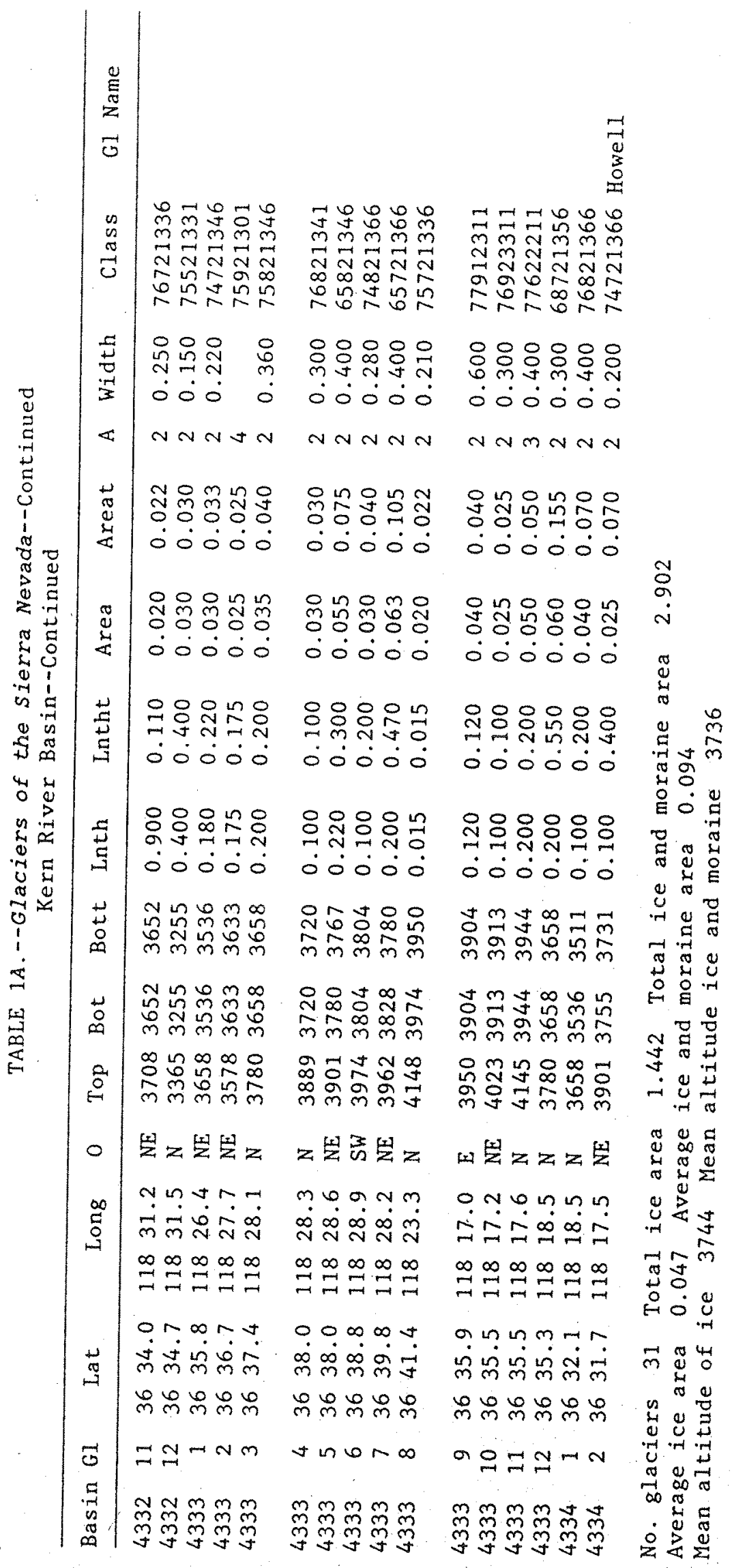




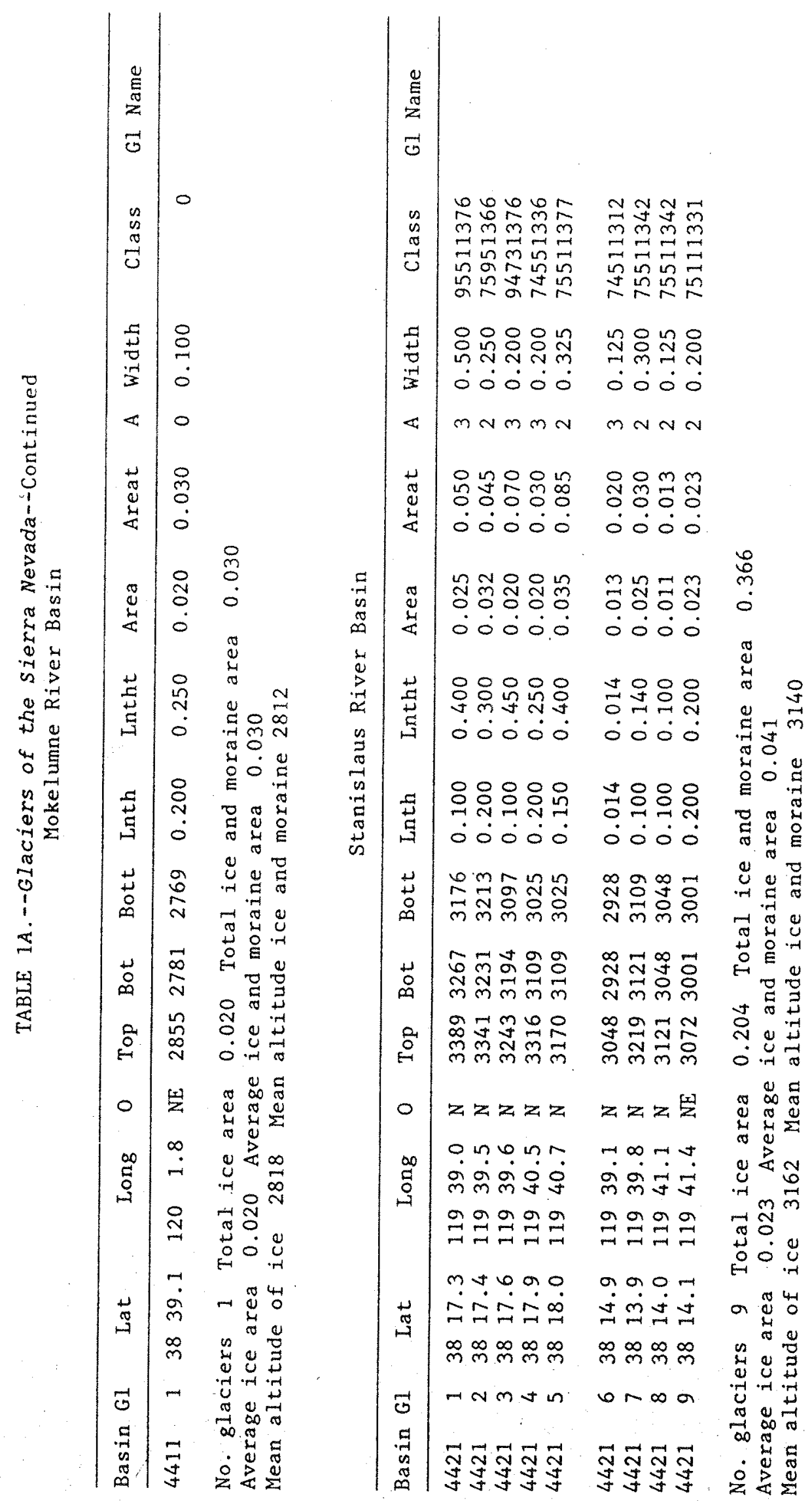




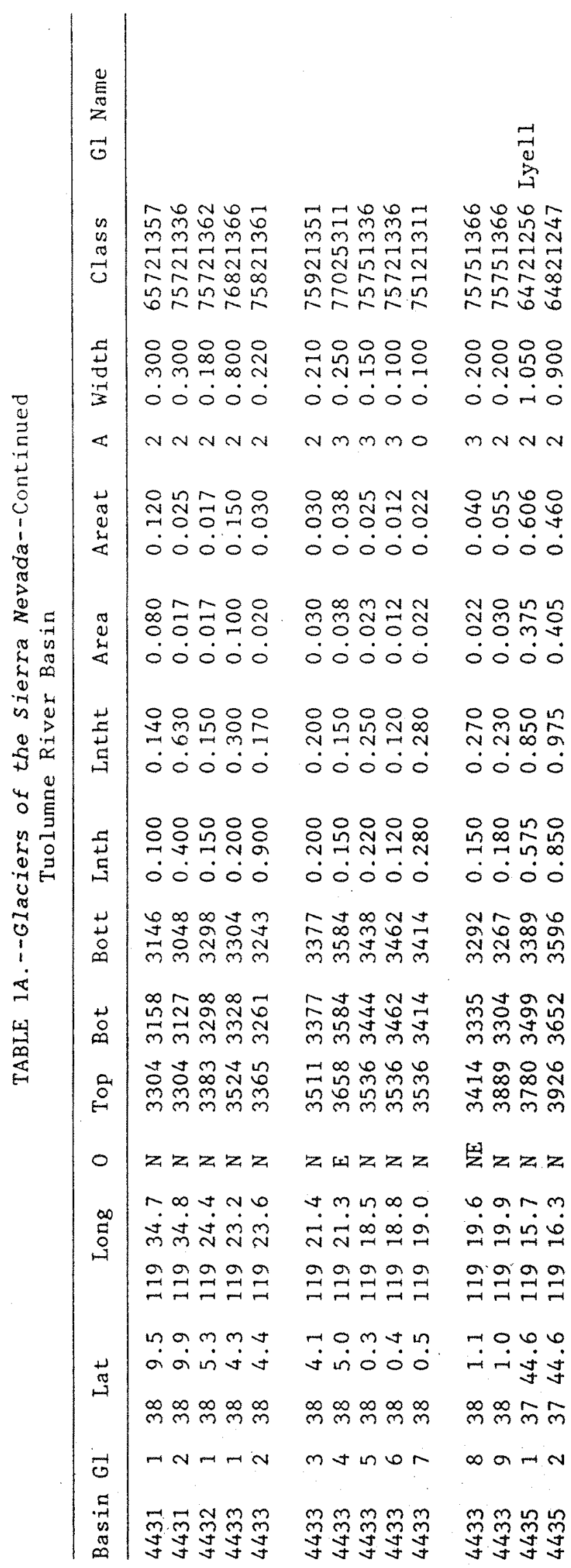




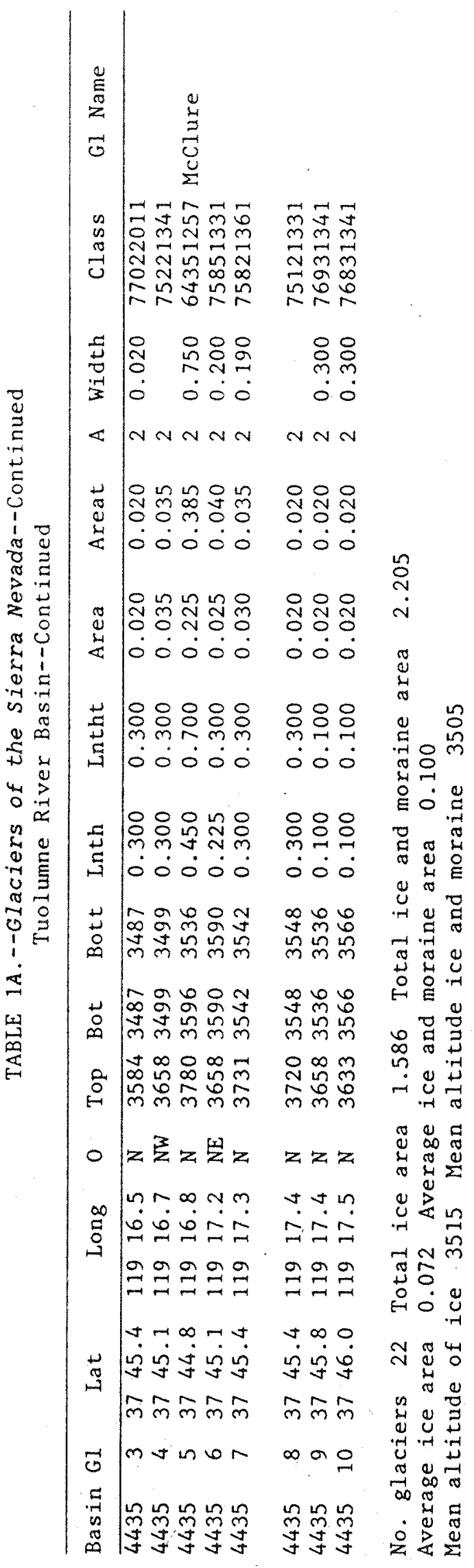




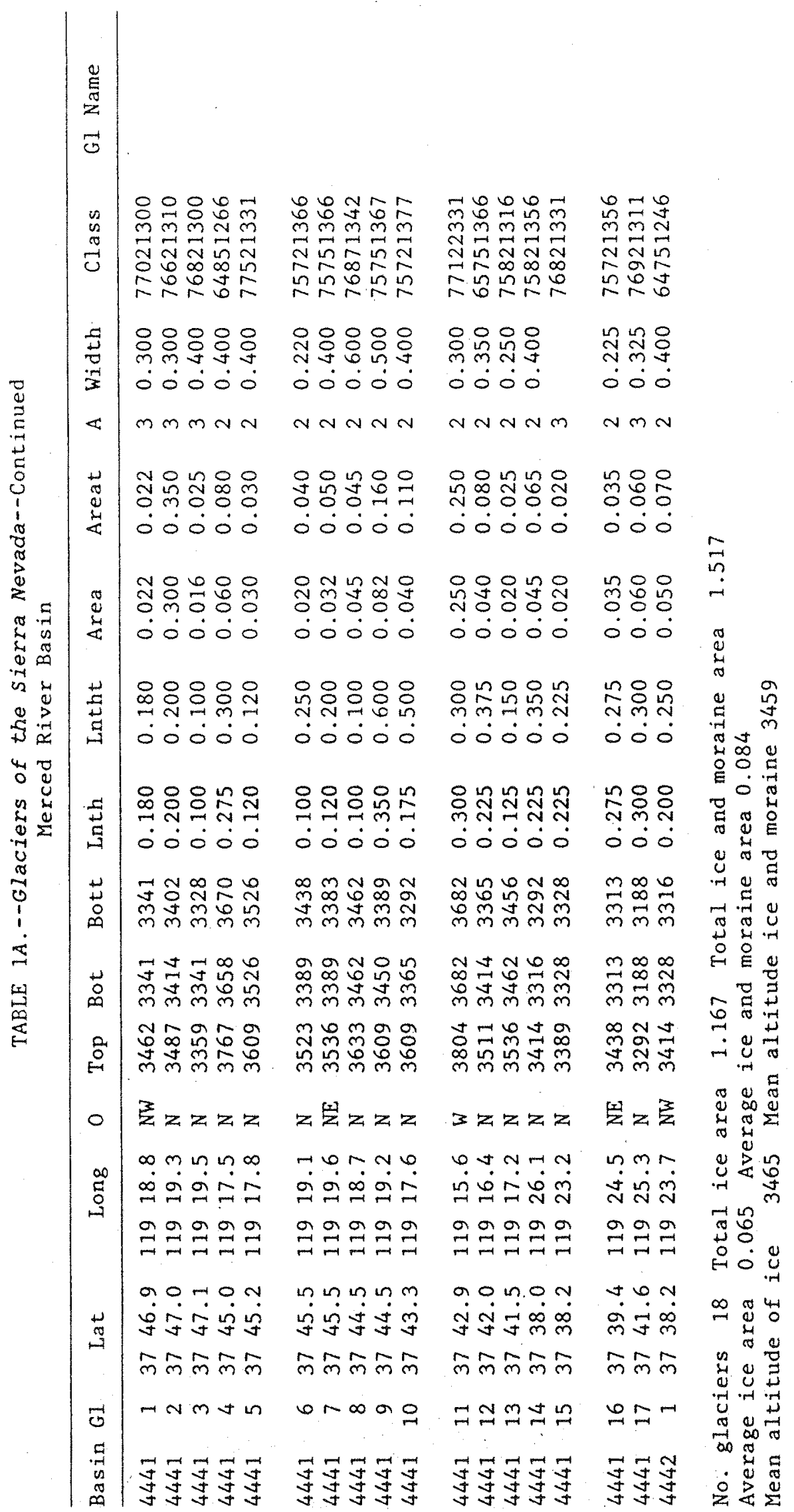




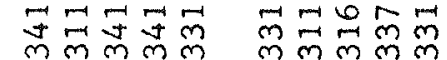

$\rightarrow-n-n-m$

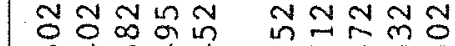

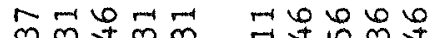

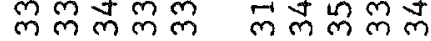

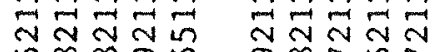

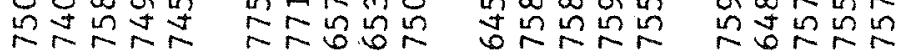

은용ㅇㅇㅇㅇㅇ

\section{옹ำำㅇำ}

வ் $0 \dot{0}$

i० 0 0

은ㅇㅇㅇㅇㅇㅇㅇㅇㅛ

nחt?

○ं0்0

ㄴํํํํㅇㅇㅇㅇ

moN

NeNN

Nend

00000

凡

ㄴํㄴำ용요

:00:

응ำำำ

¿0ं00:

nNNMN

00000

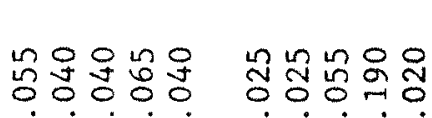

응ํํㅇํํㅇํㅇ

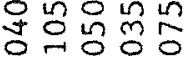

0ं0்

mo.

웡용요는

00000 00000

00000

0ं0.

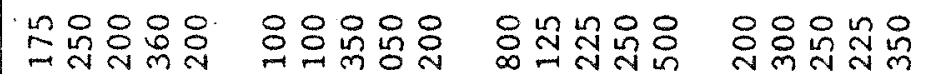
000:0 $\dot{000} \dot{0} 0$ 0000்

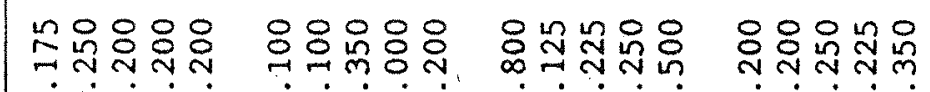
00000 000.0 00000 00000

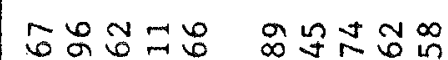

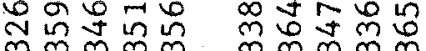

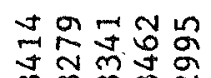

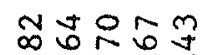

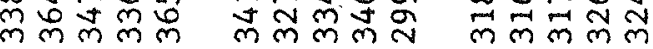

$\sigma 6 \underset{6}{6} \approx 6$

$\ln +2 \infty$

$+2 \pi 0$

Noorm

Nin लmmm $\mathrm{mmm}$

누 $\infty \infty$

No⿱ $)$ ॠ ले लूल लूल

min

tort in

$\operatorname{mon}$ at ले लू m

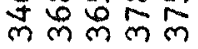

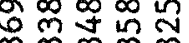

그ำ

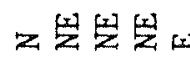

被学3

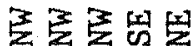

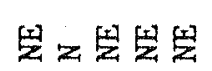

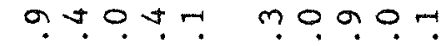

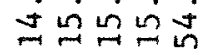

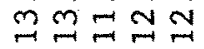

mog 9 n

NoO 01

영의 의의

풍요

वंबं

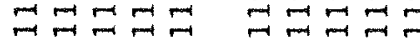

o क o o

웜욤의의

N $* \infty 0$

rom 0

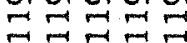

H $n-1$

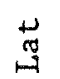

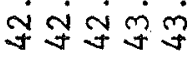



$\infty \mathrm{m}$ ? 50

$\infty \infty$ ort

लnलm $\hat{m} \hat{m}$

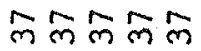

워요요유

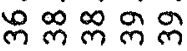

HNm

or $\infty$ 。

लिलm

लำกำ

5

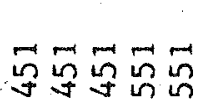
च표교

$N m+\ln 6$ 


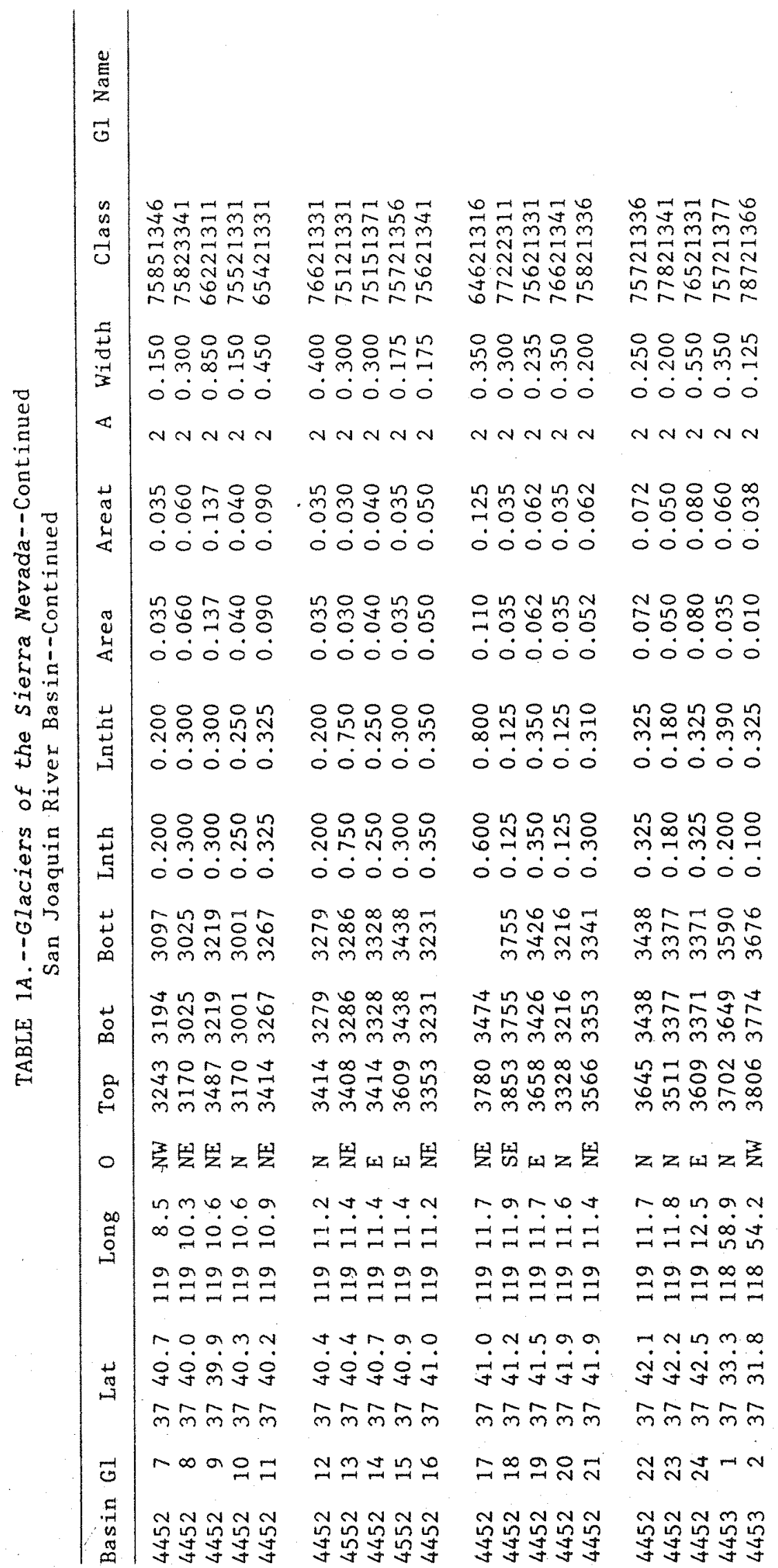




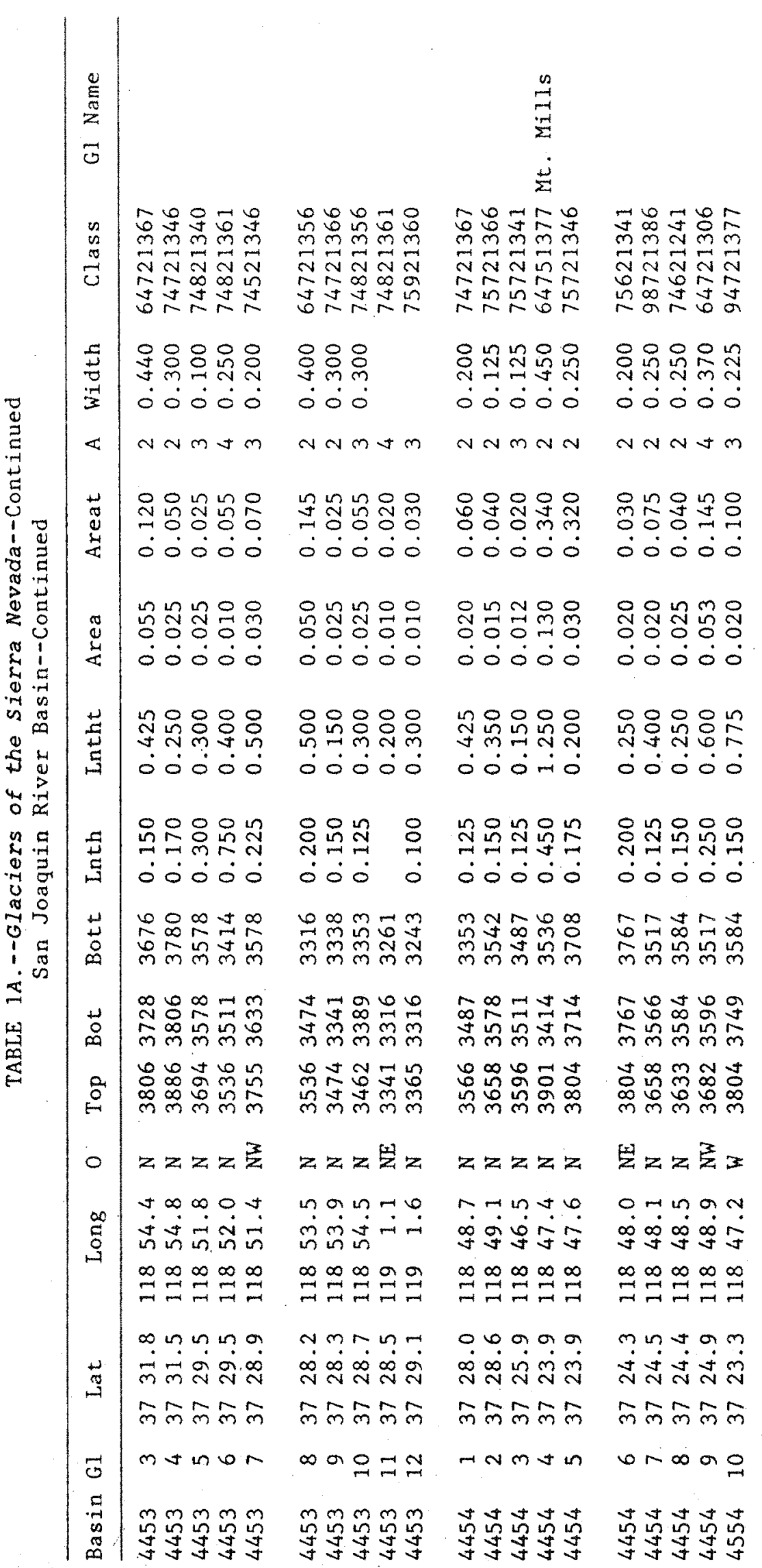




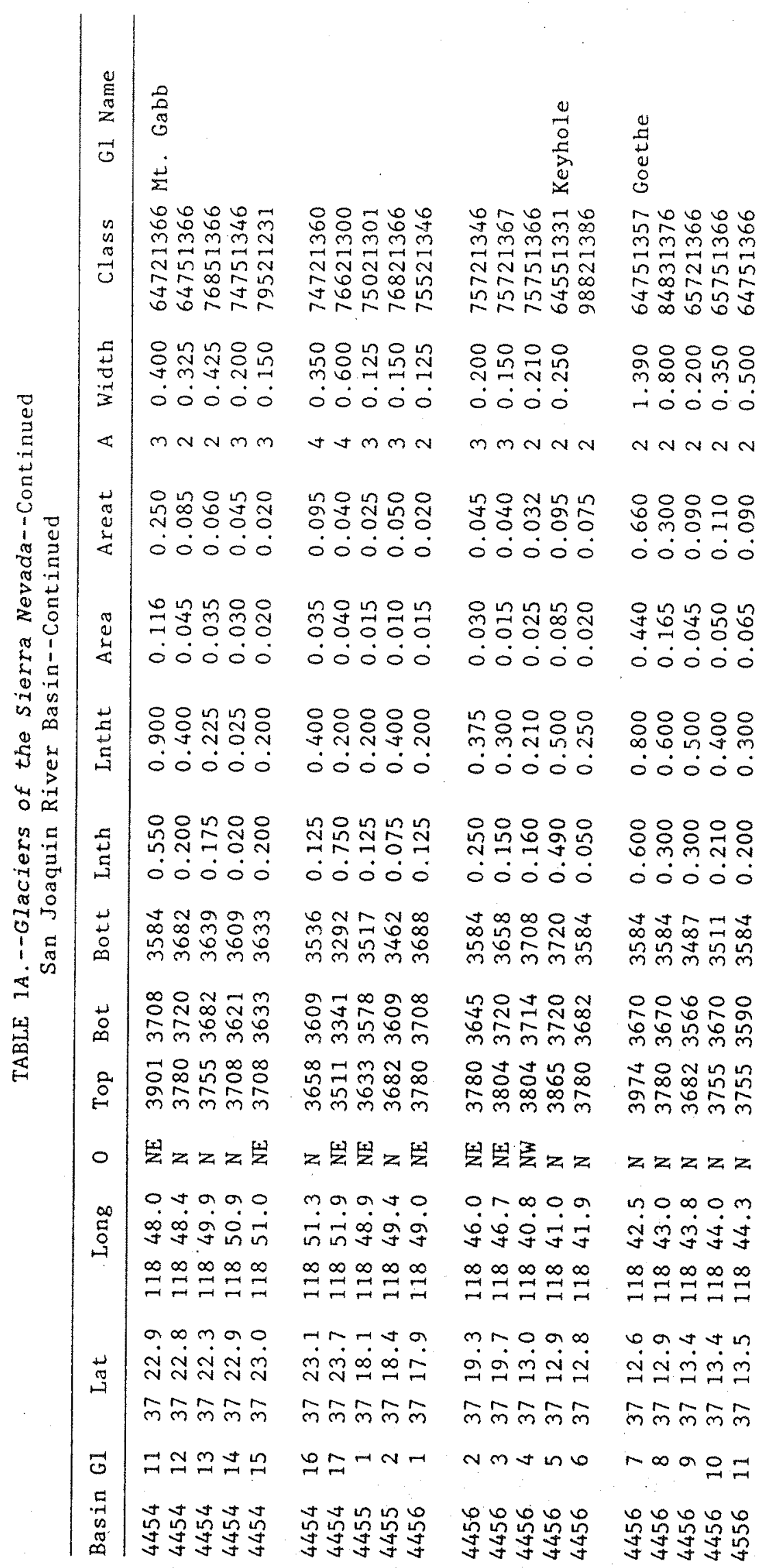




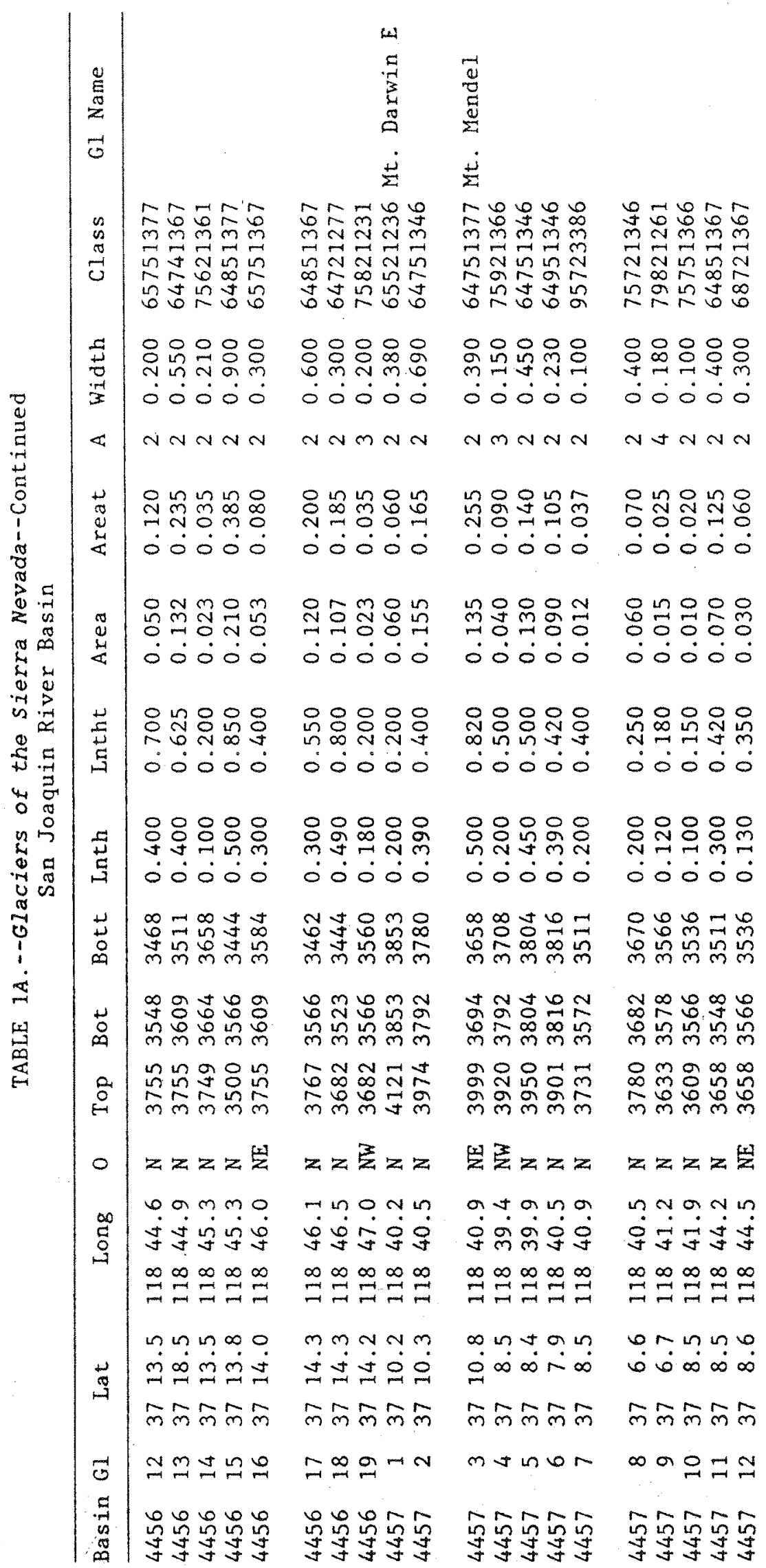




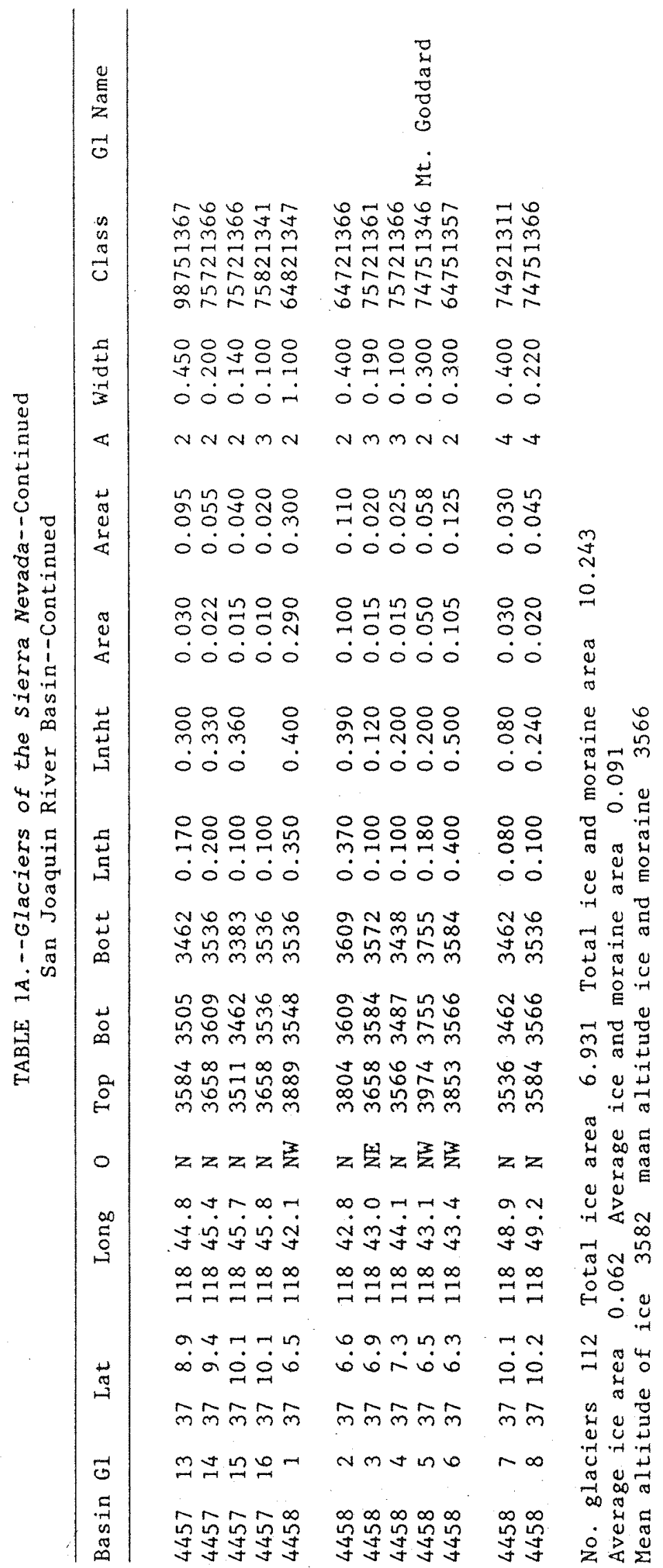




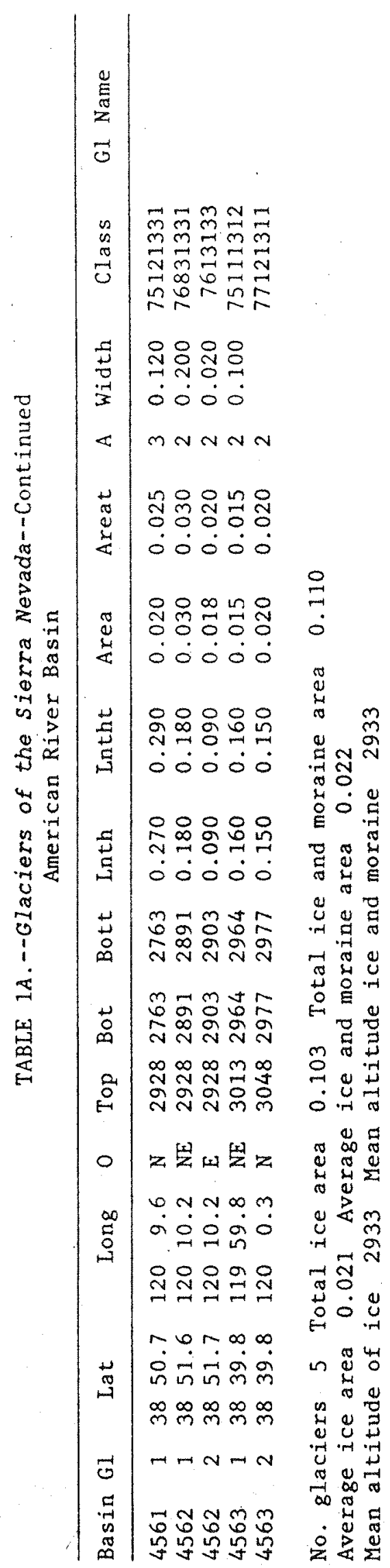




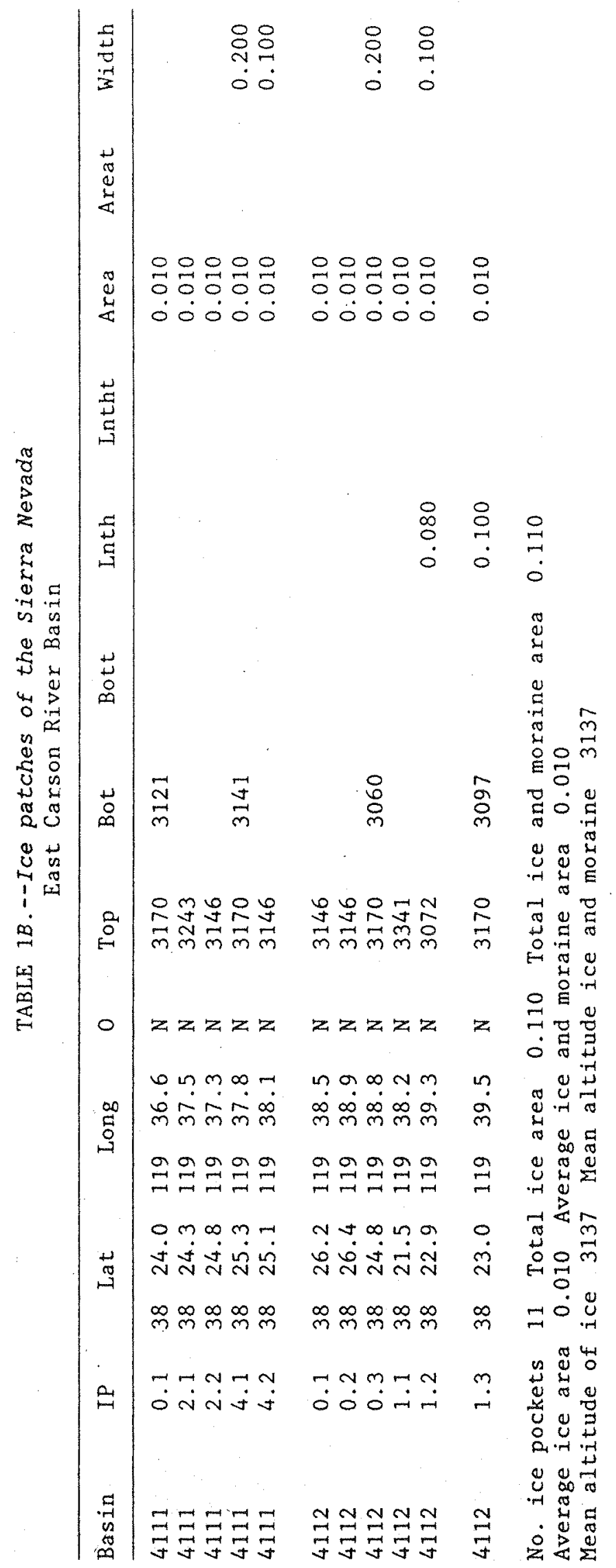




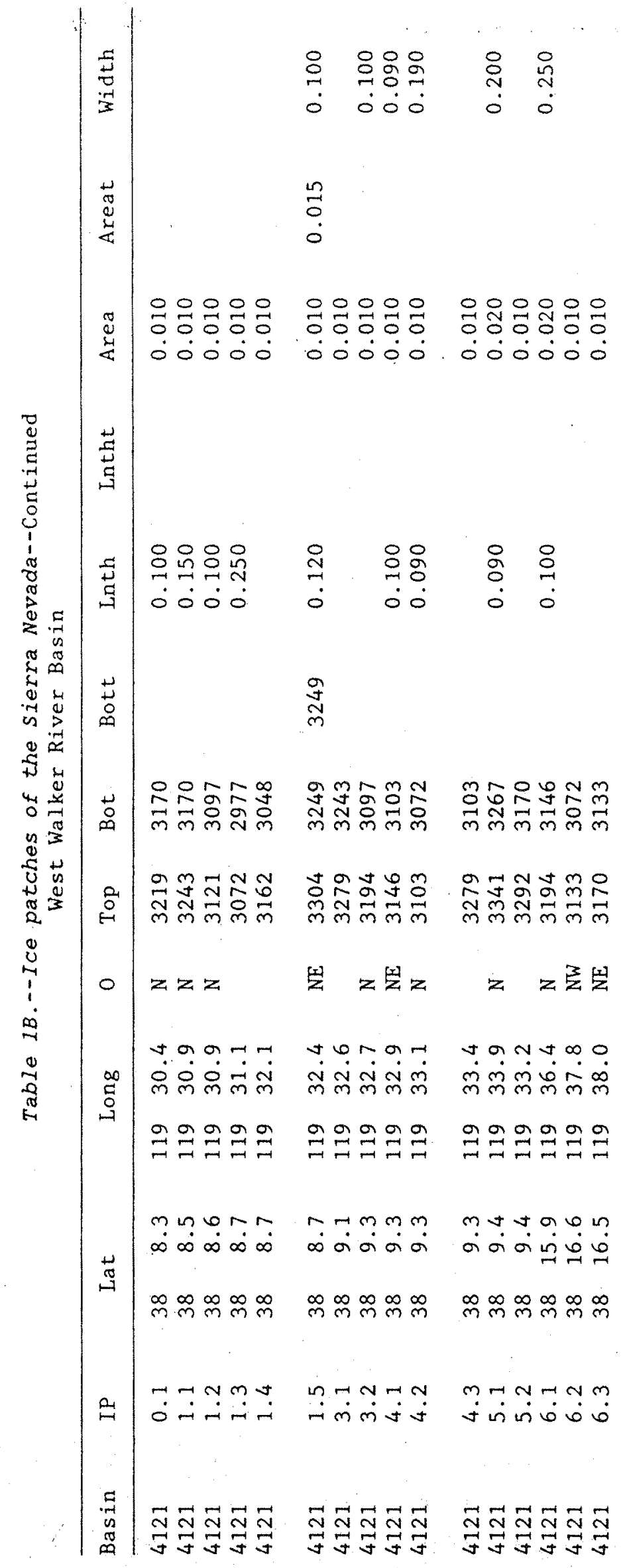


52 Inventory of Glaciers in the Sierra Nevada, California

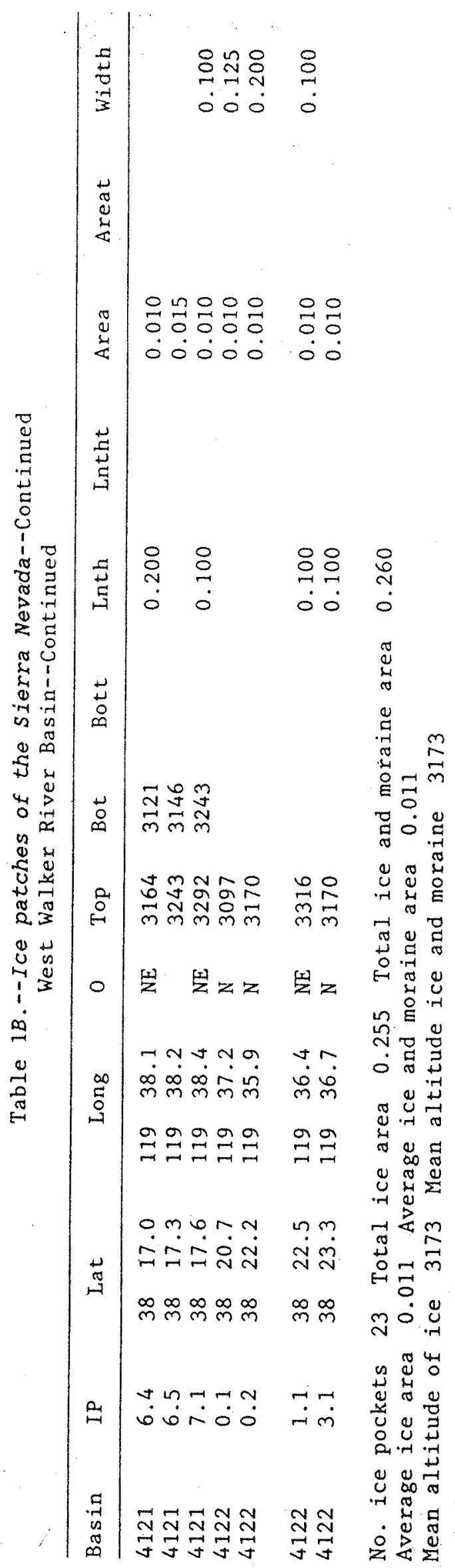




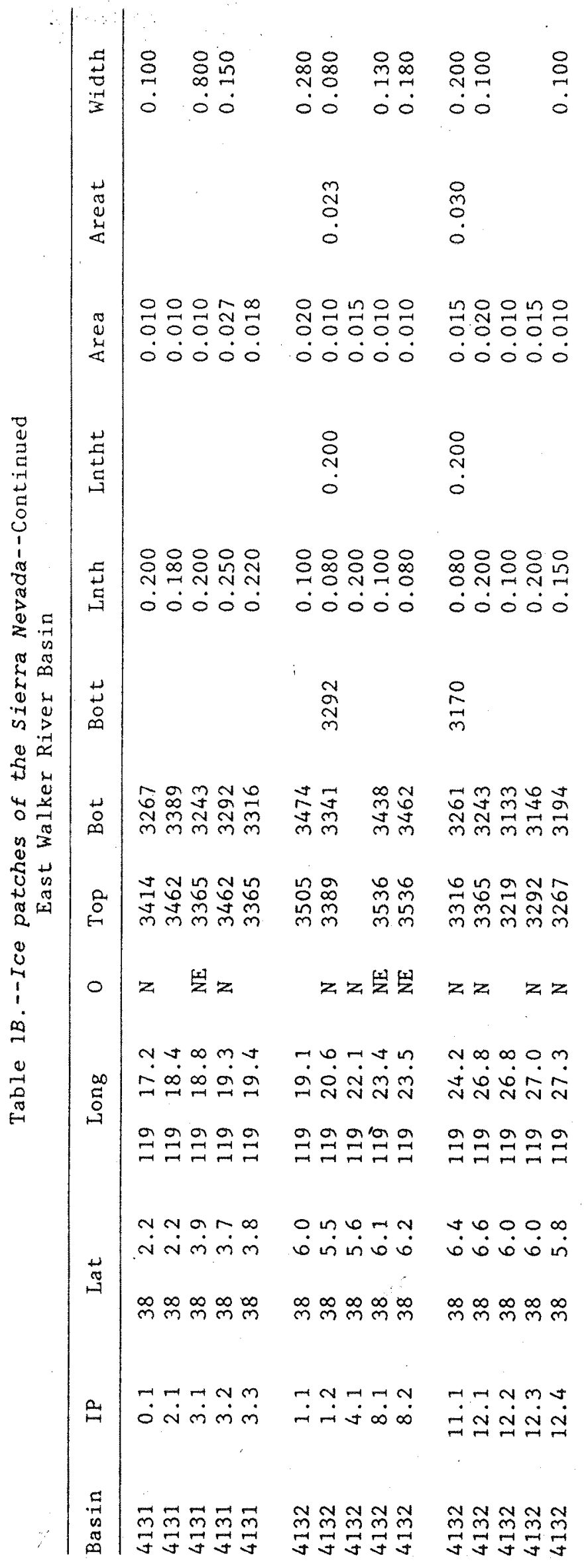


54 Inventory of Glaciers in the Sierra Nevada, California

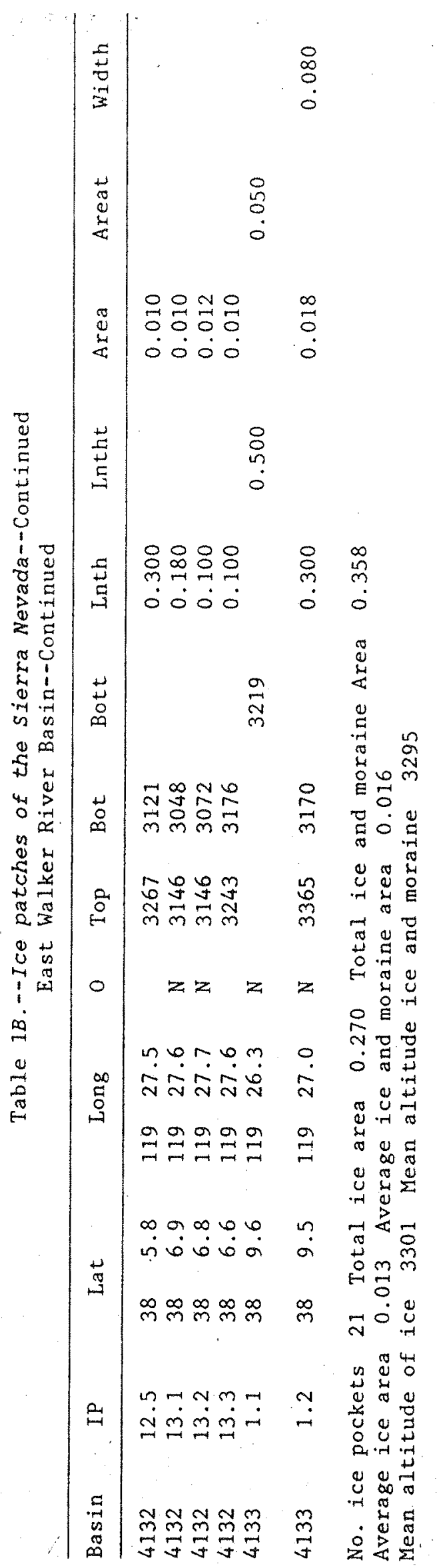




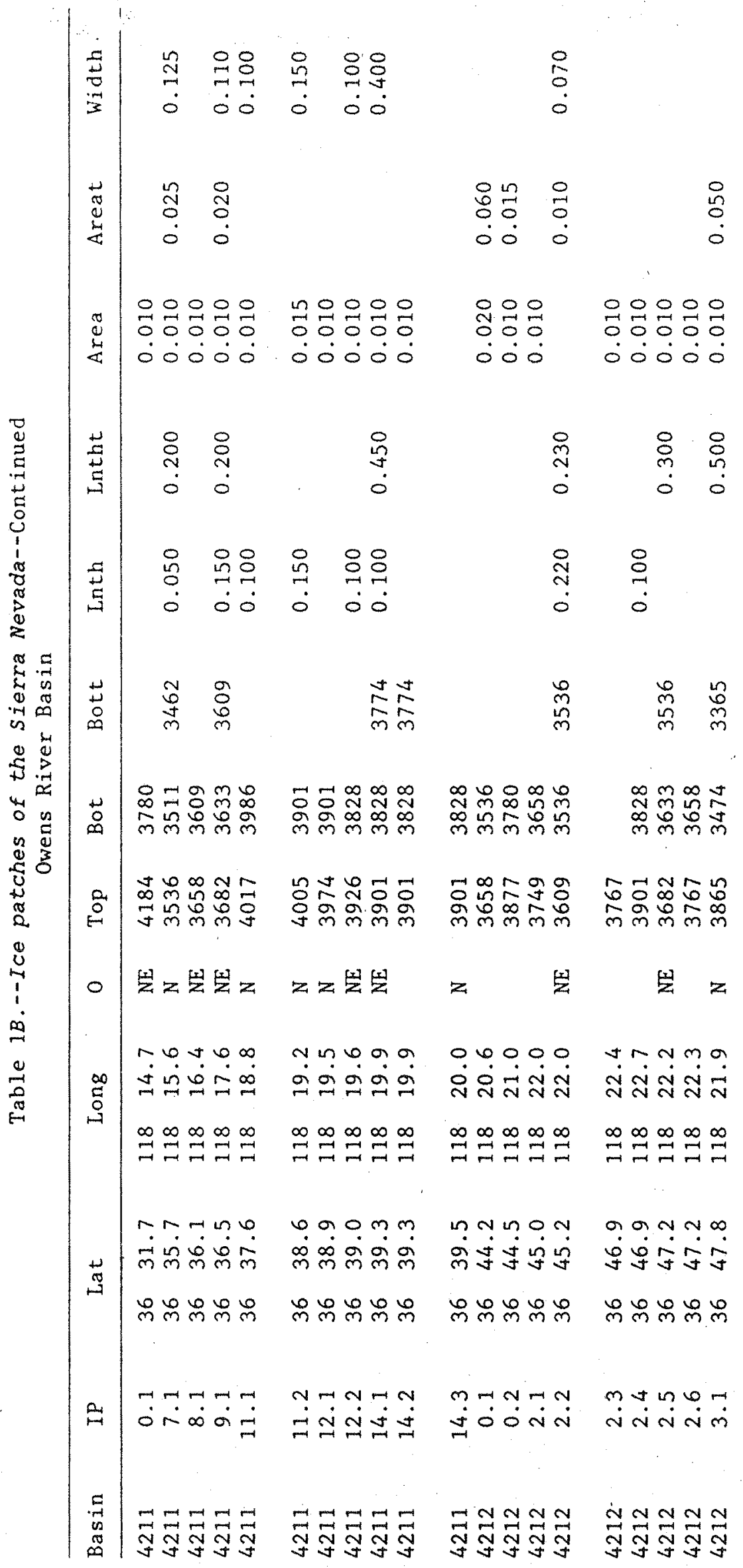


56 Inventory of Glaciers in the Sierra Nevada, California

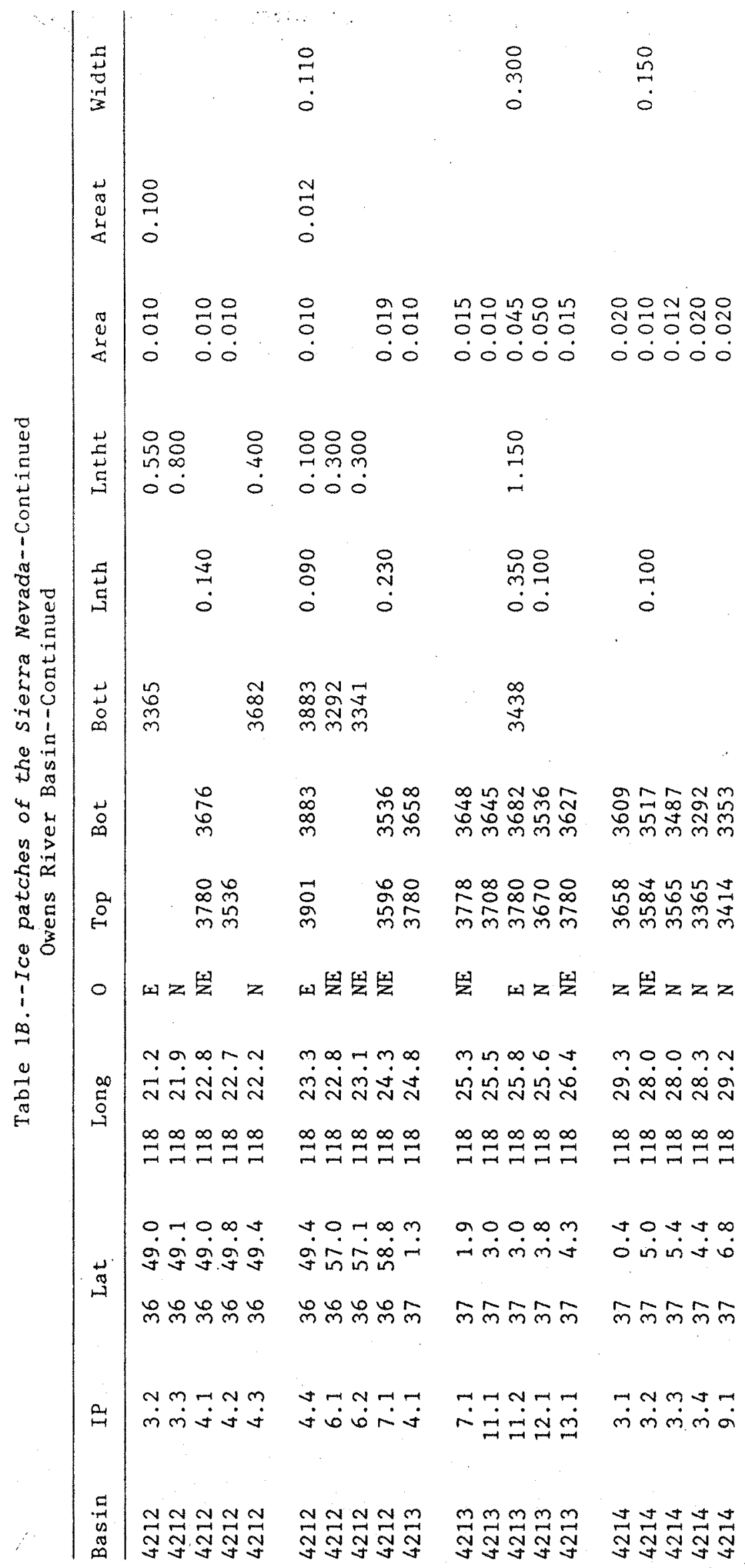




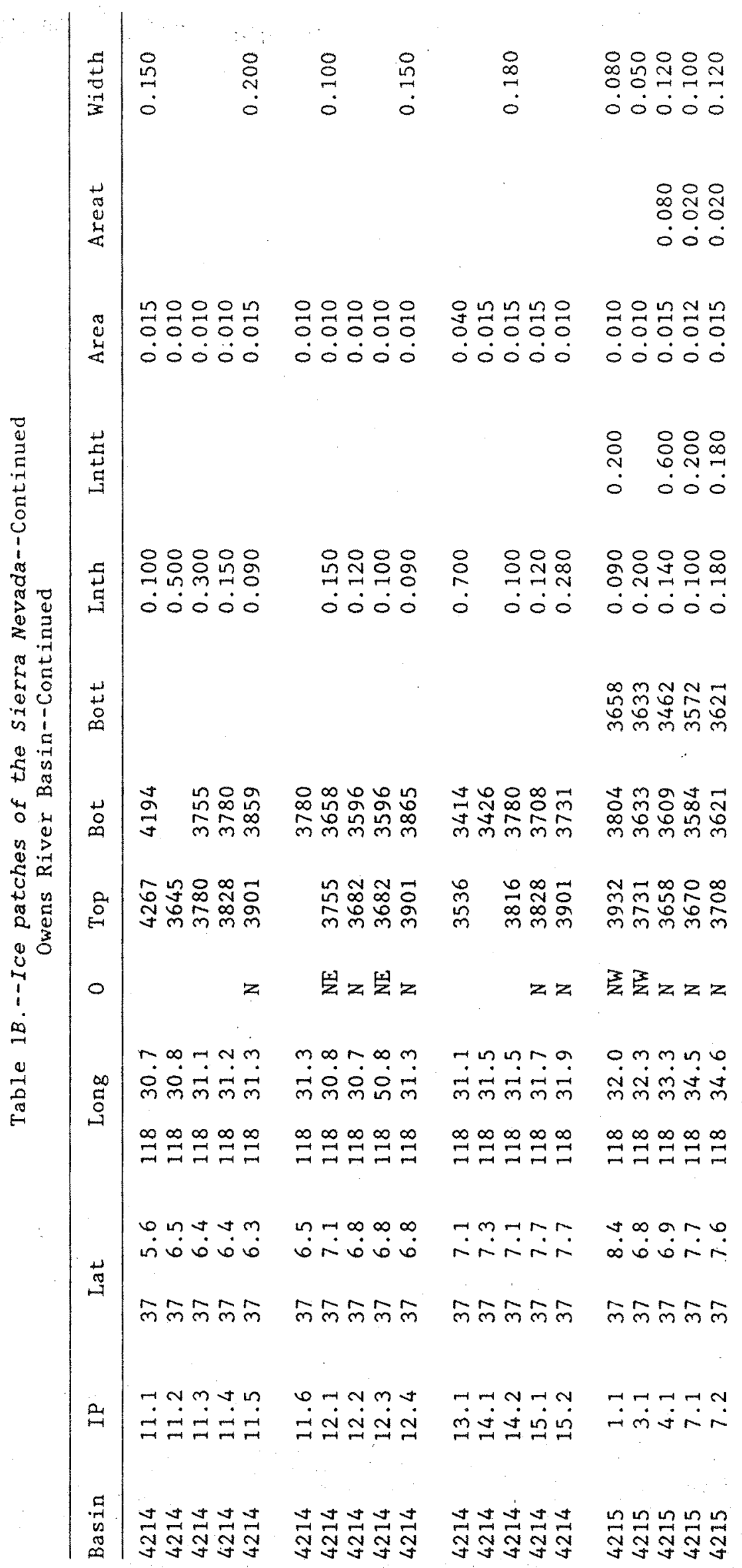




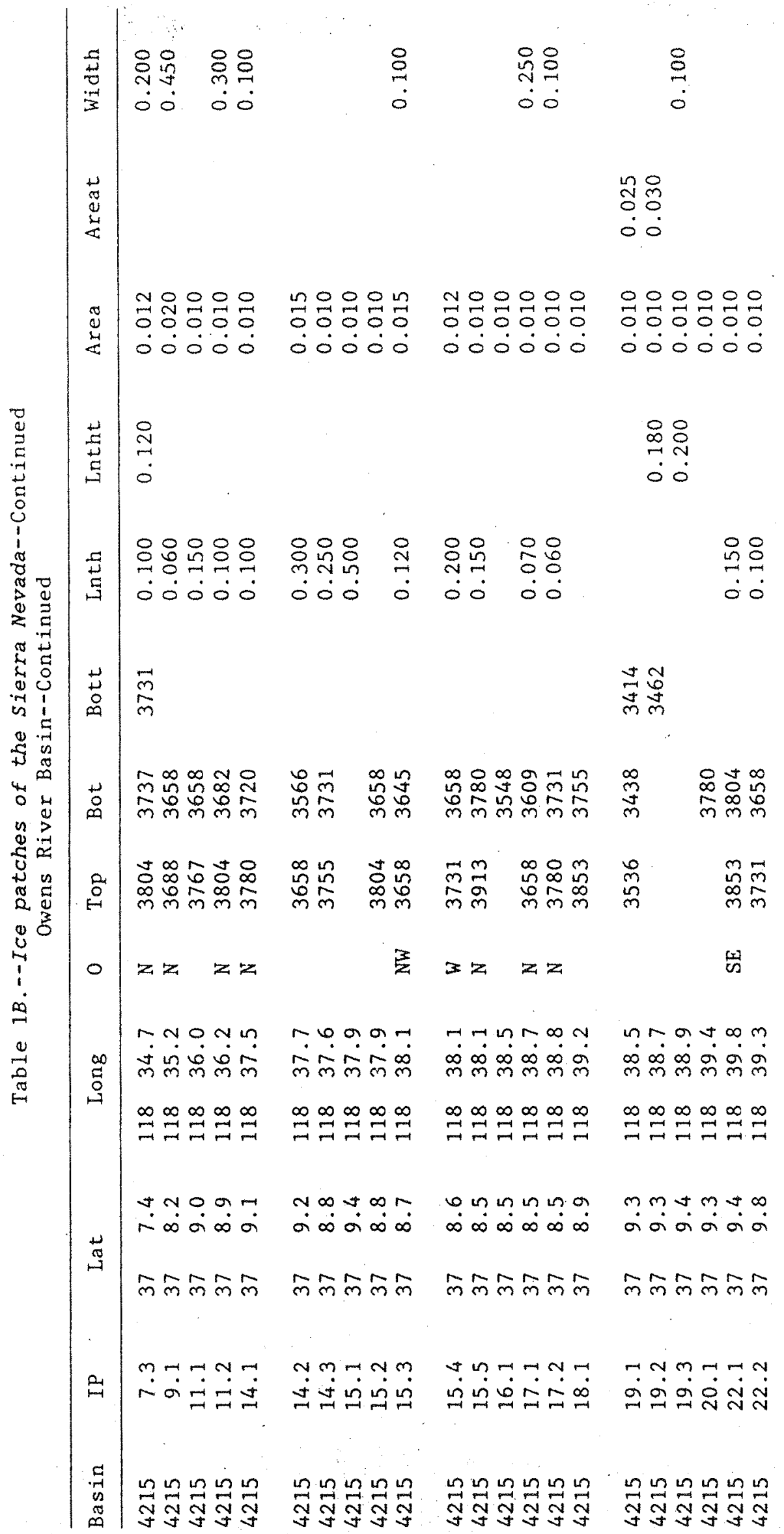




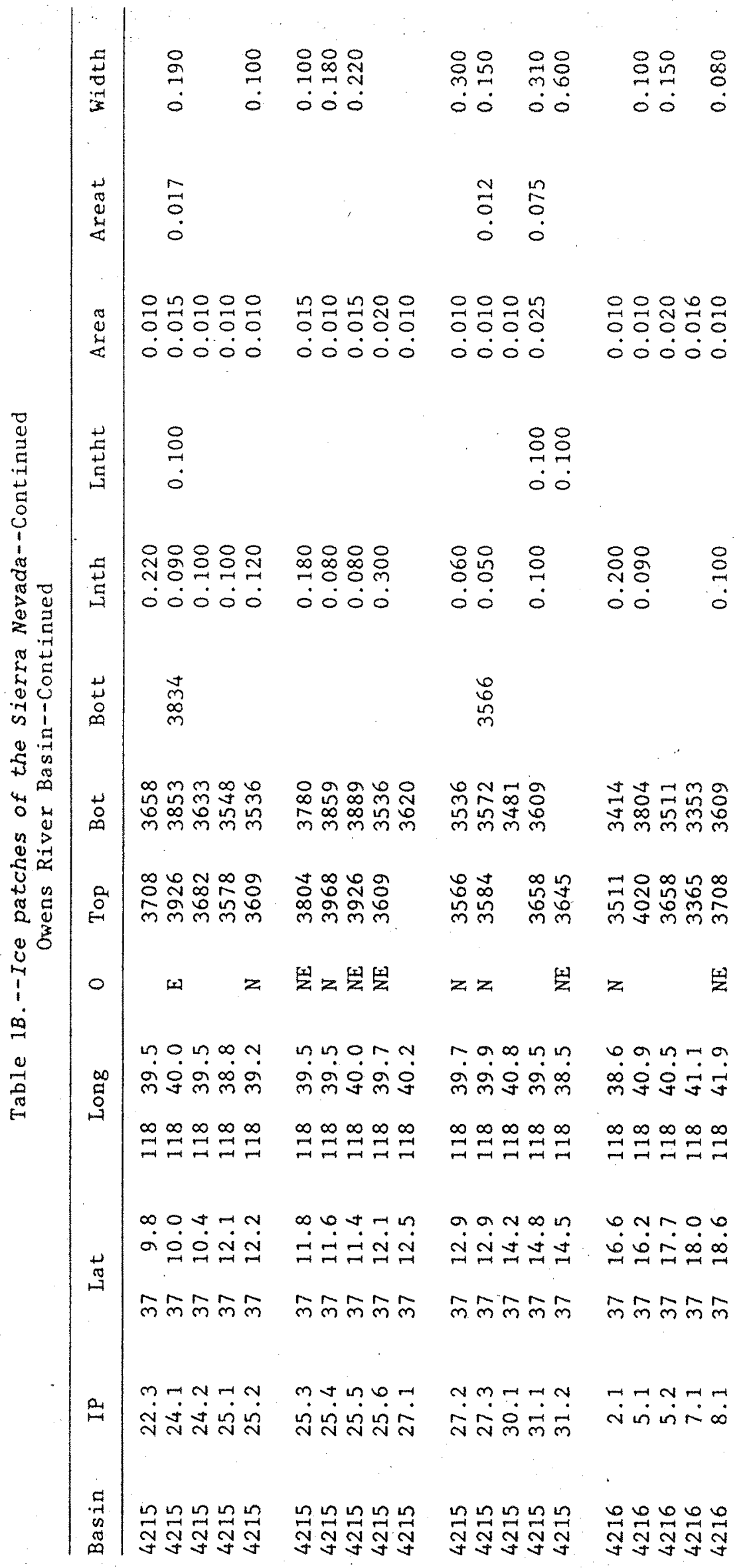




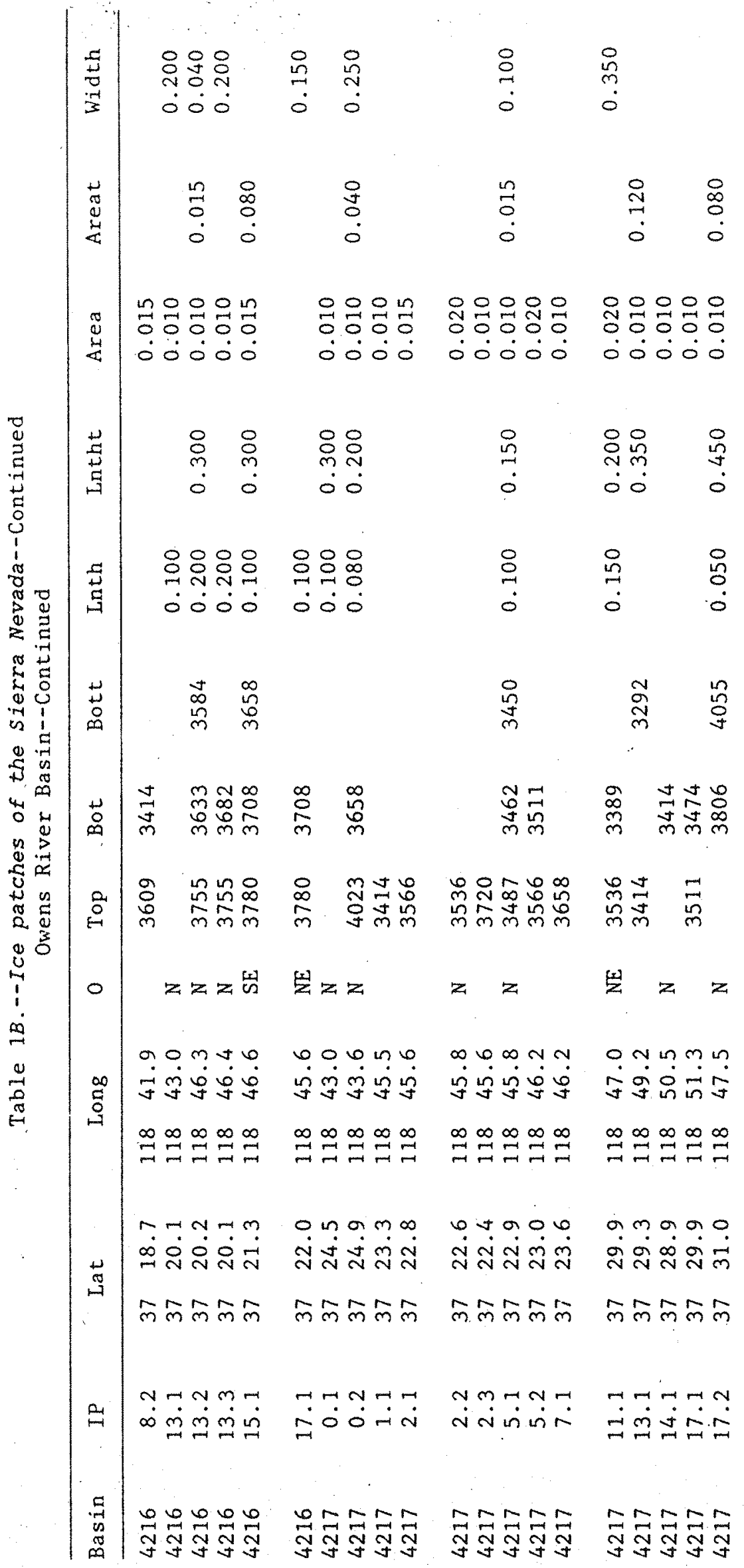









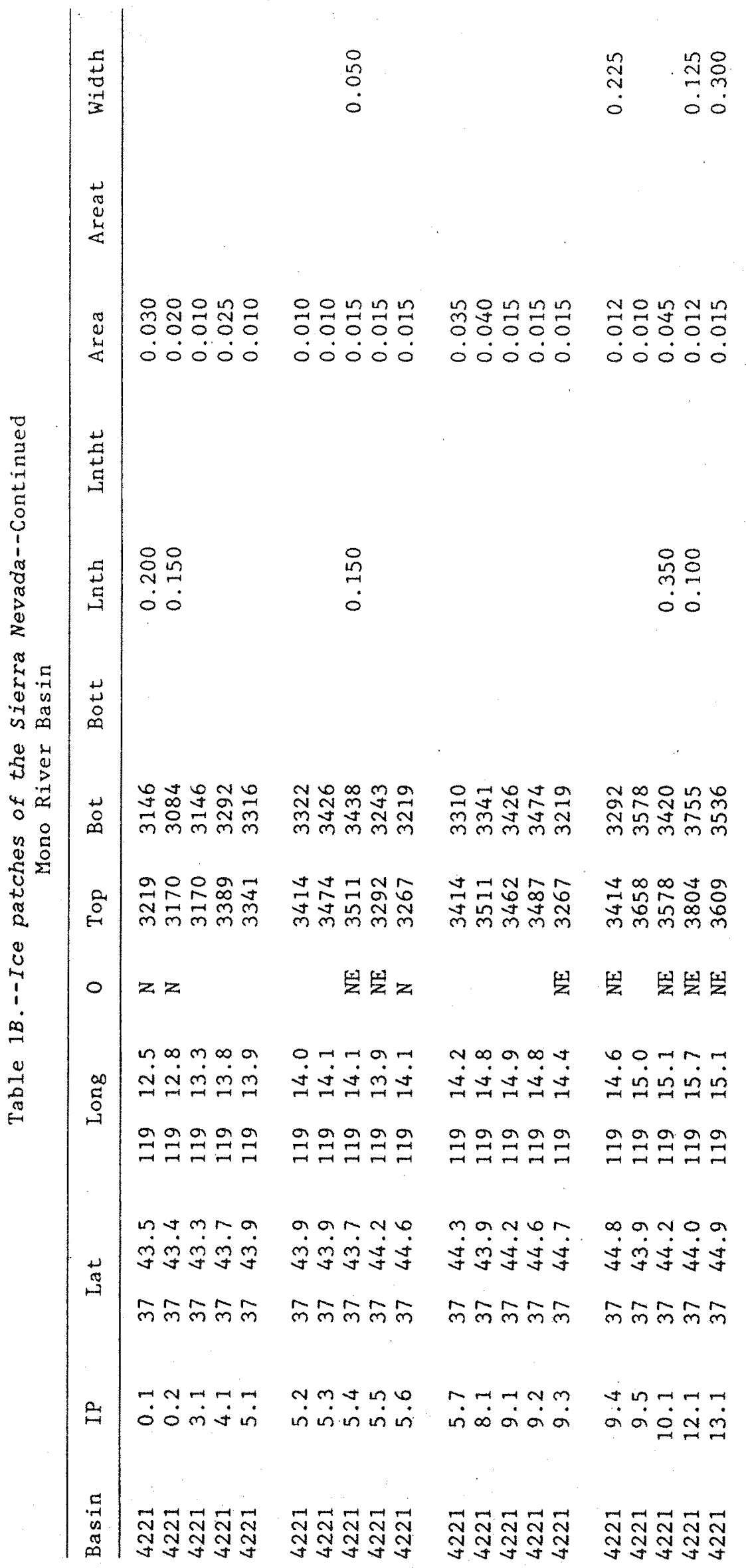




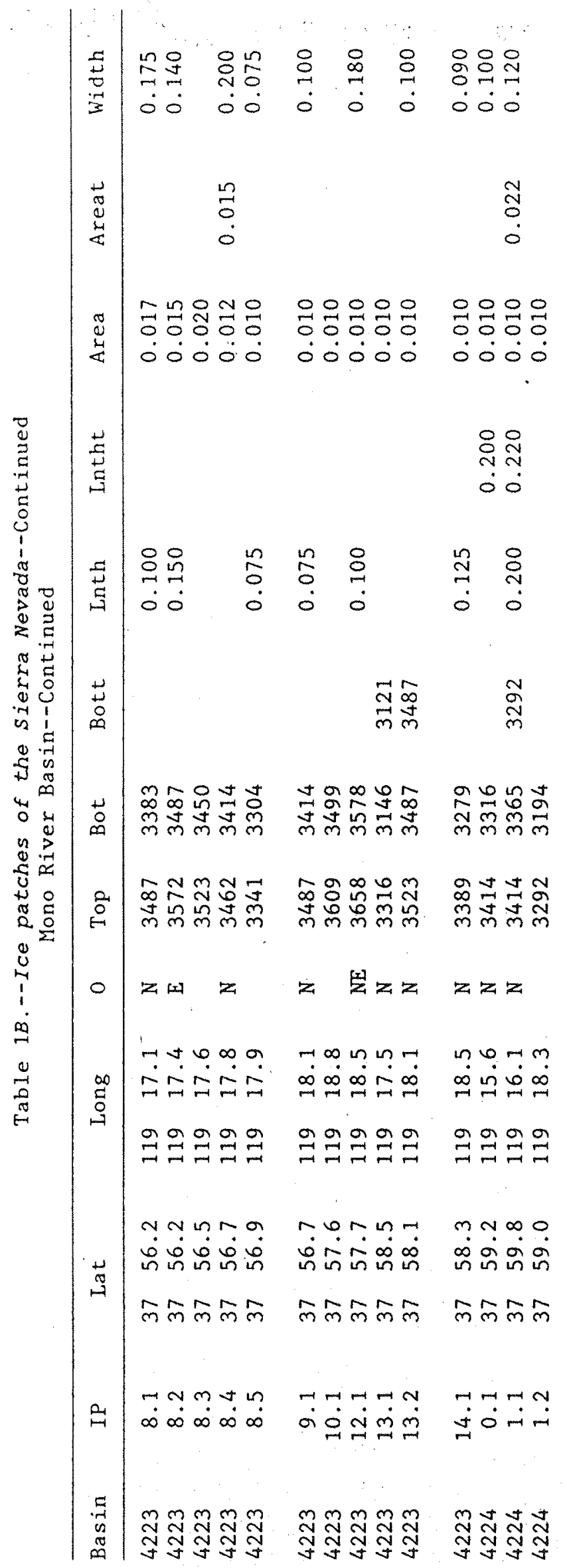


64 Inventory of Glaciers in the Sierra Nevada, California

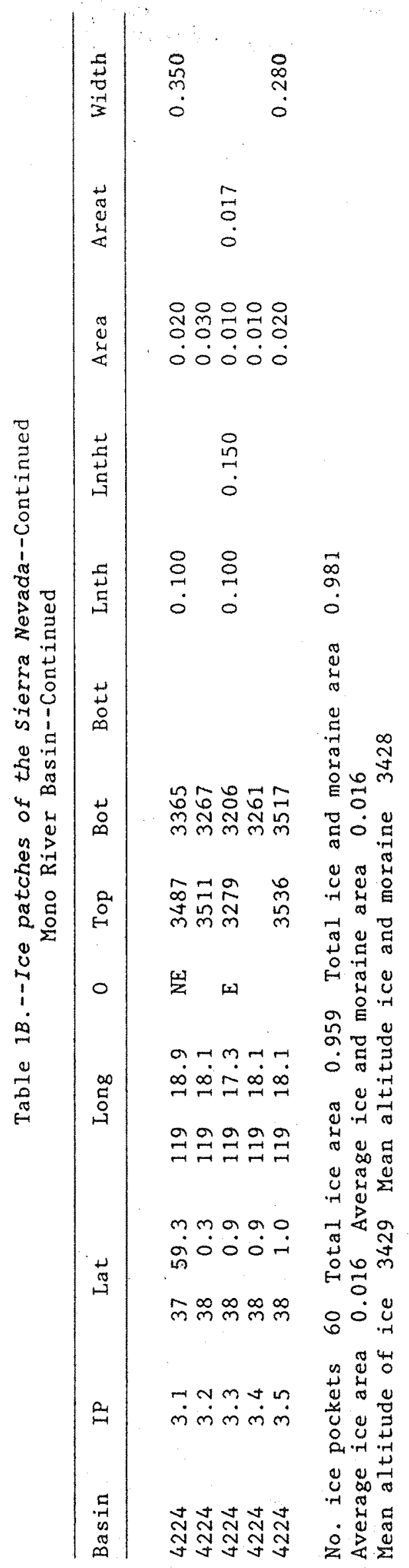




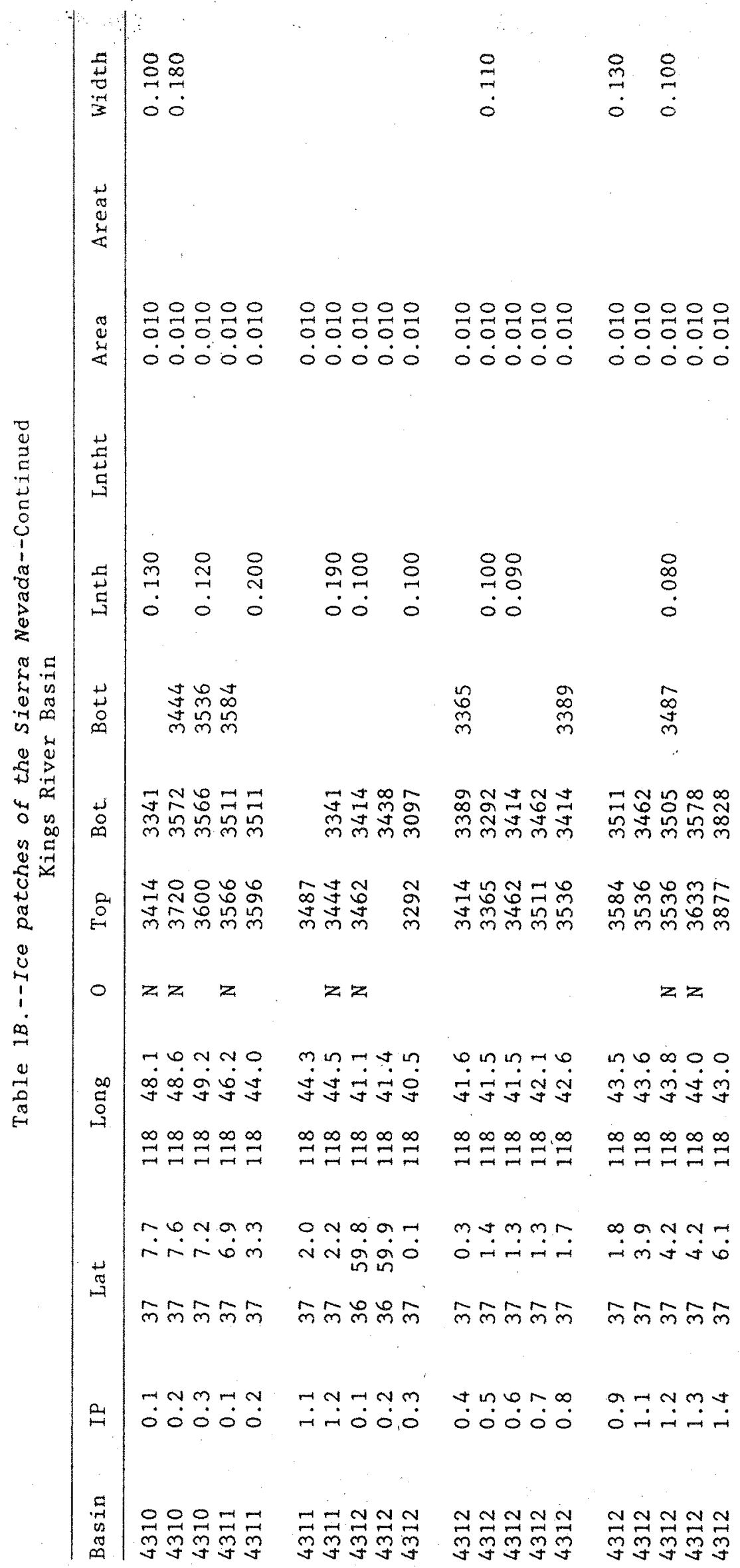




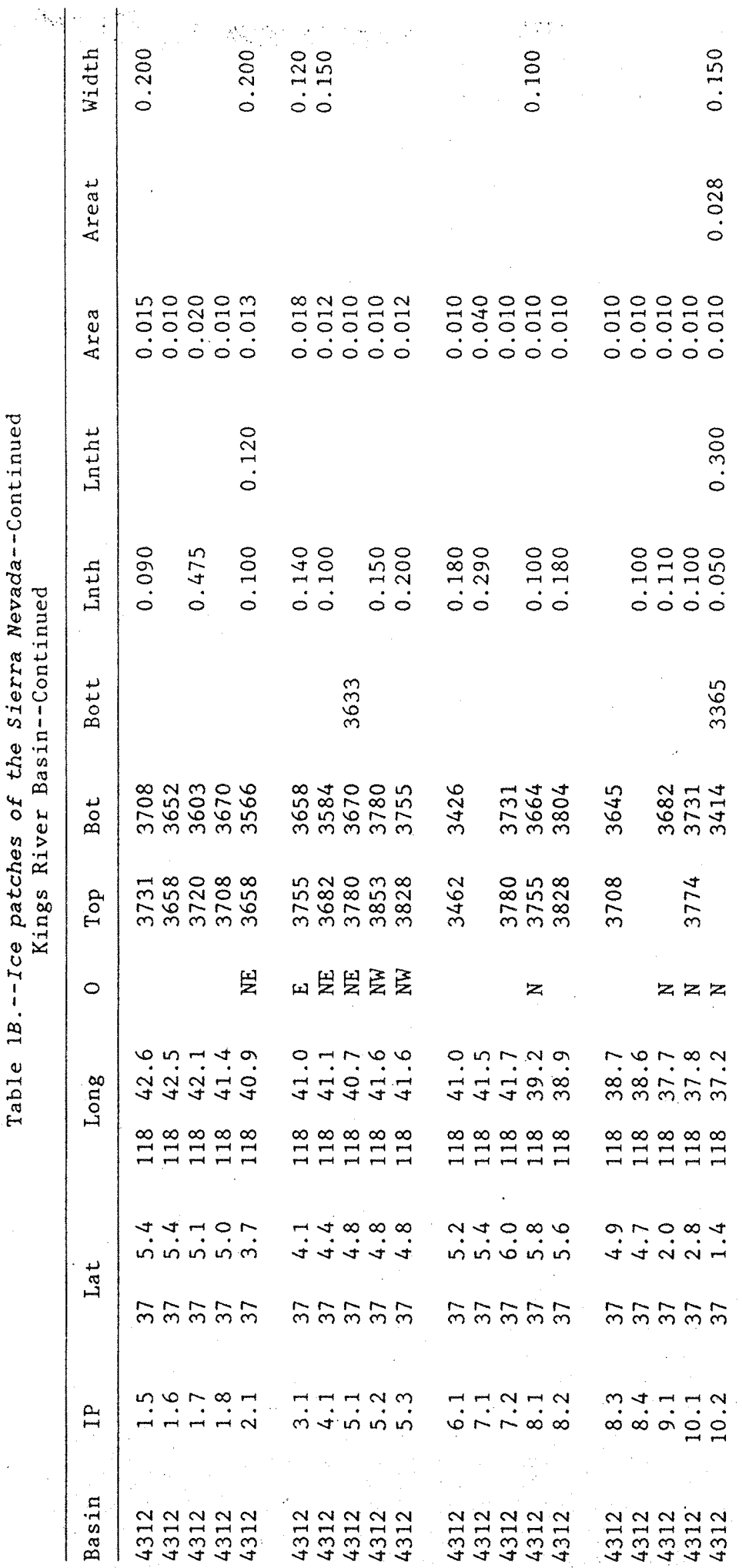




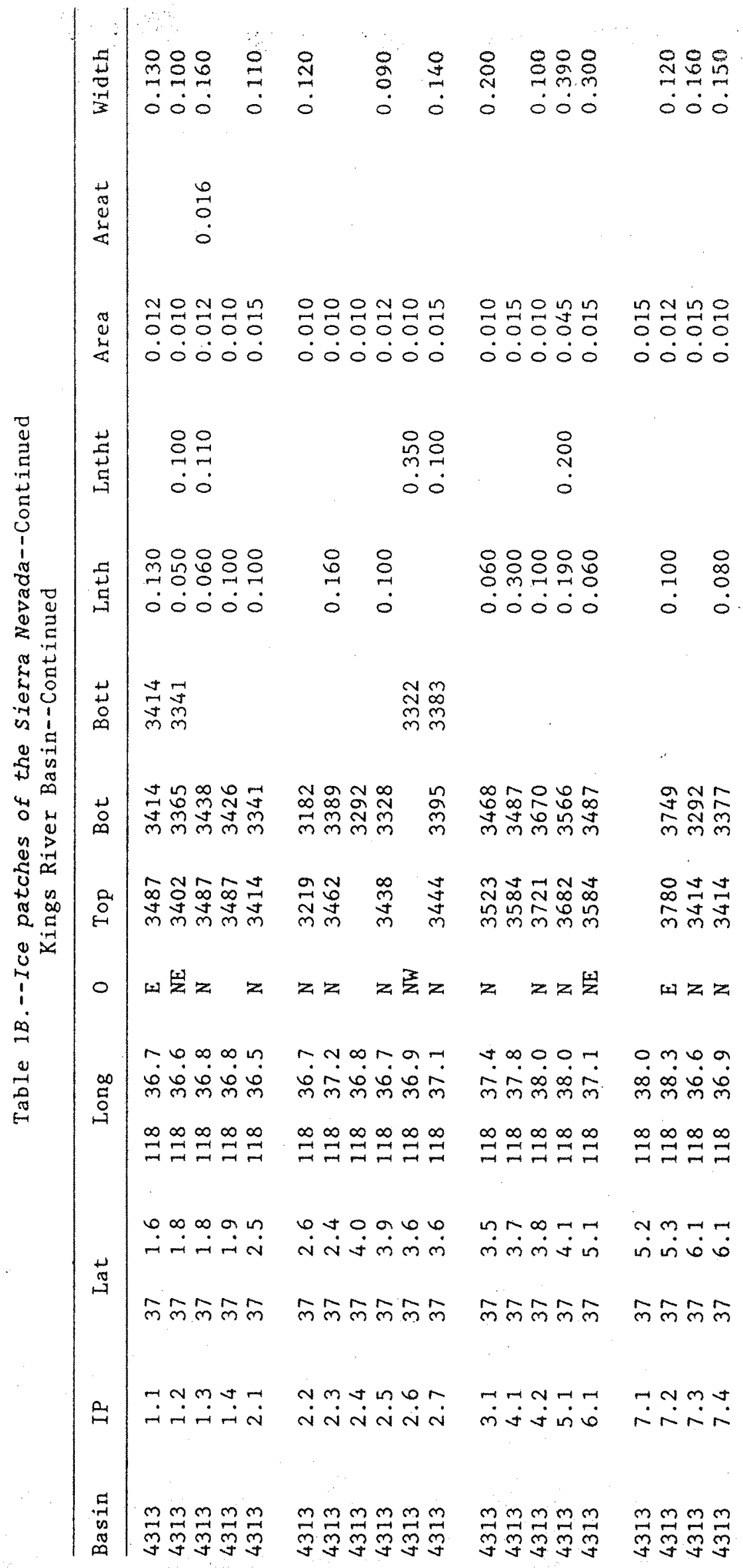




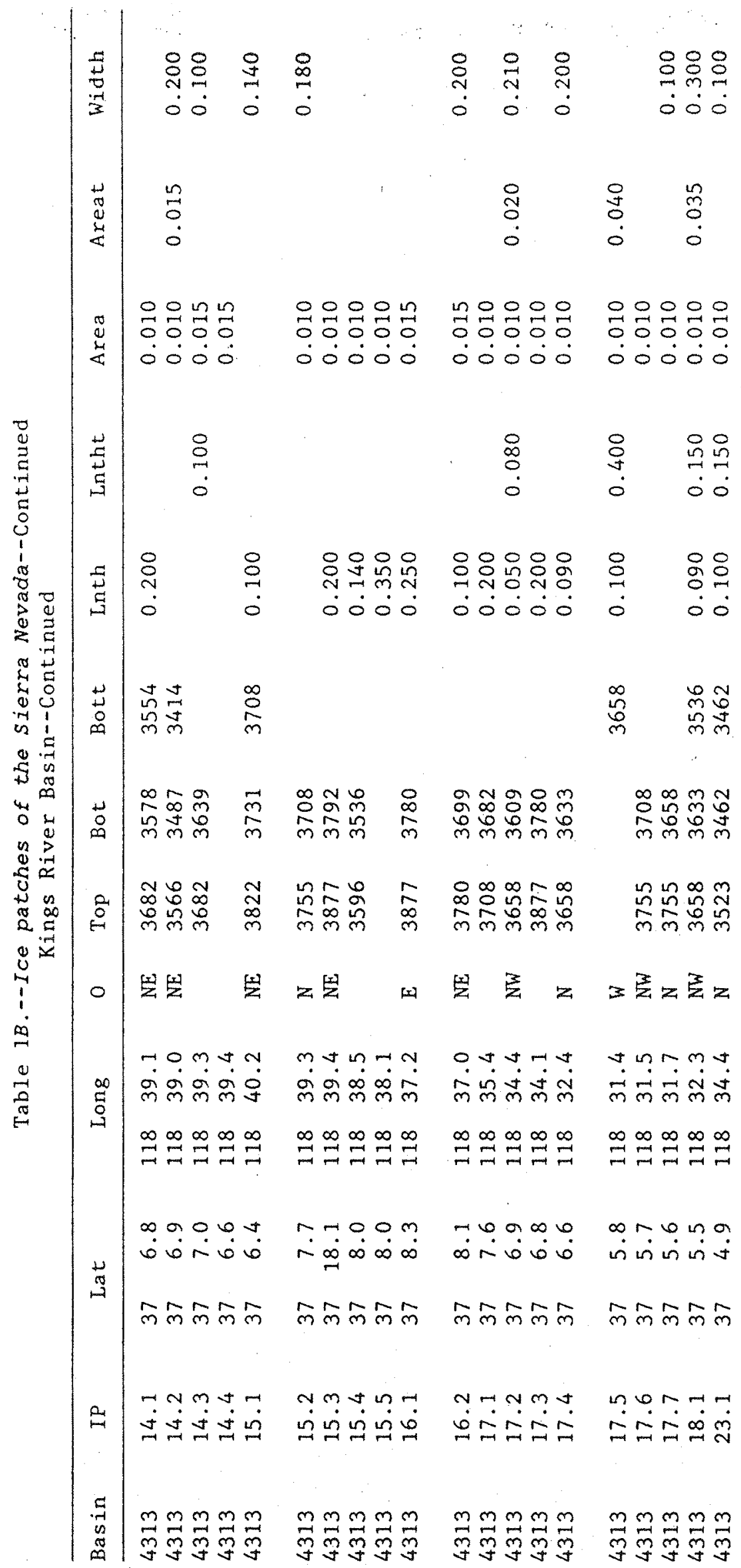




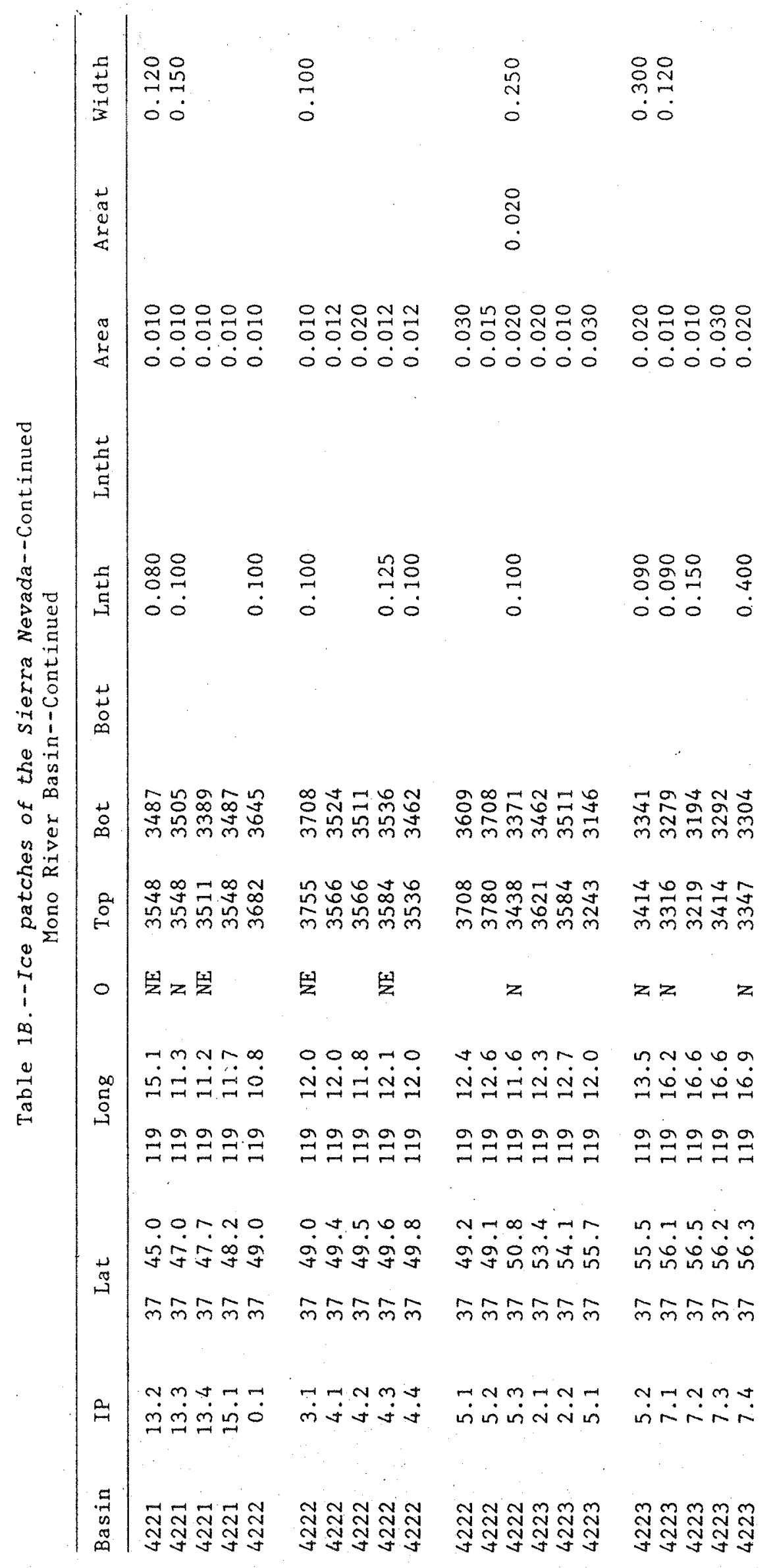




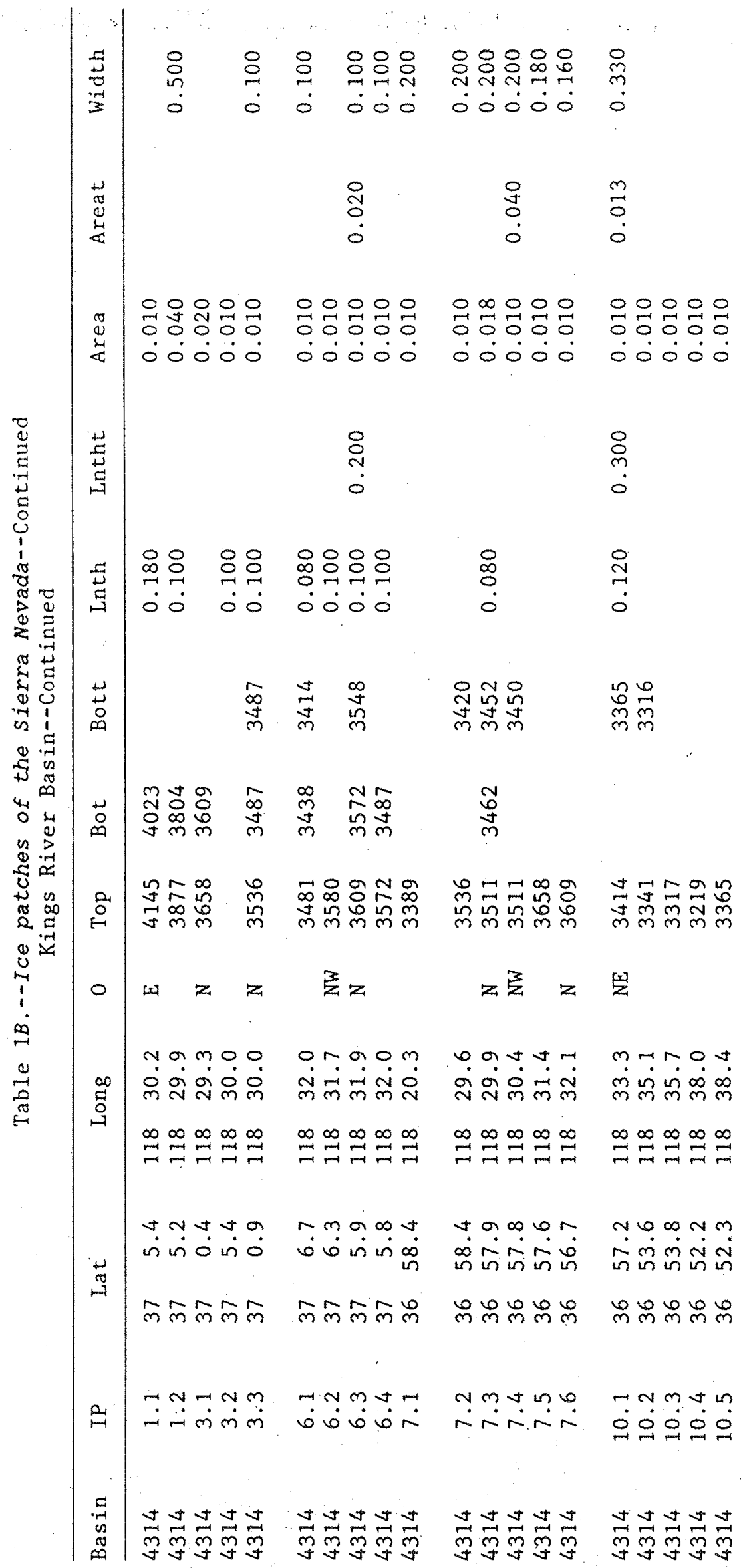




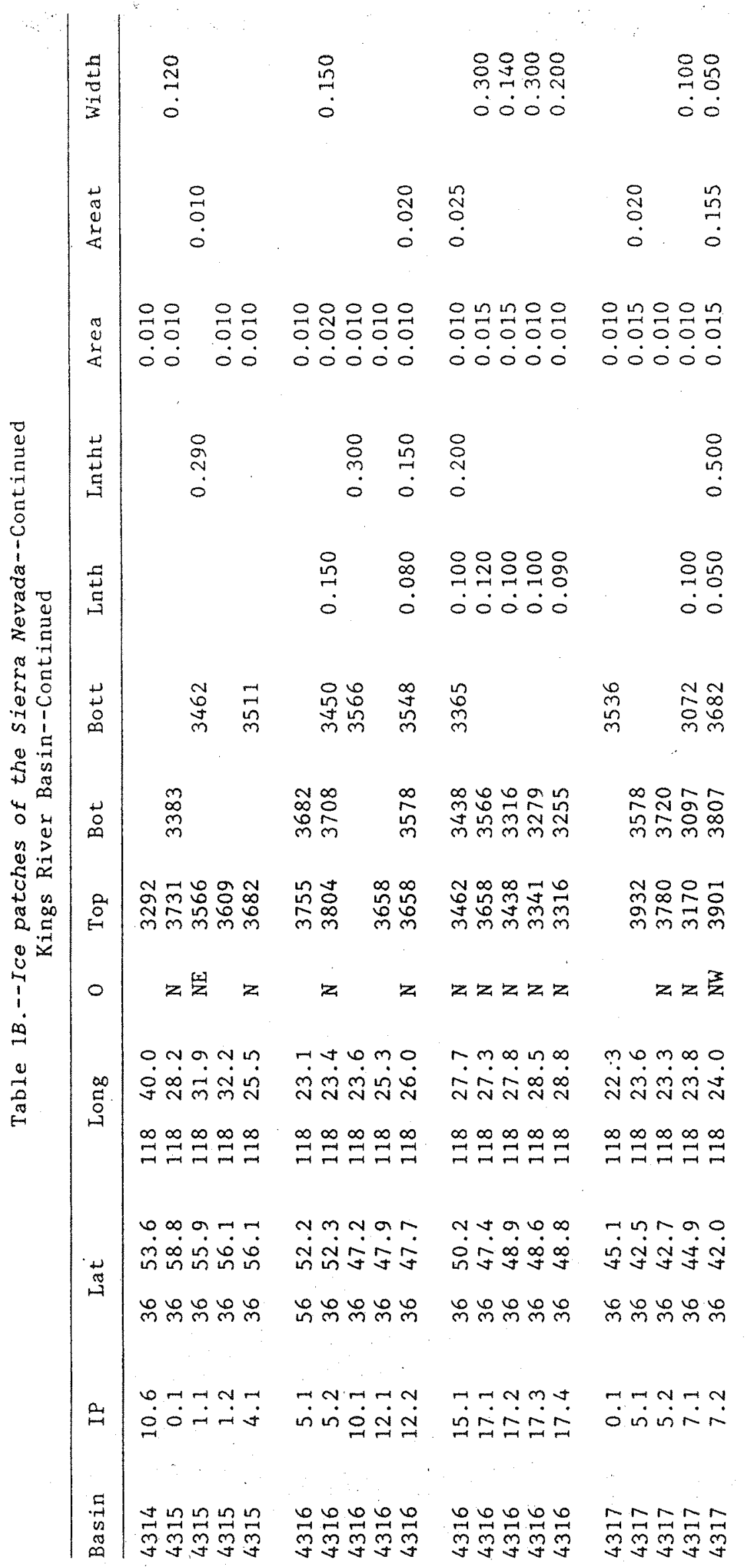




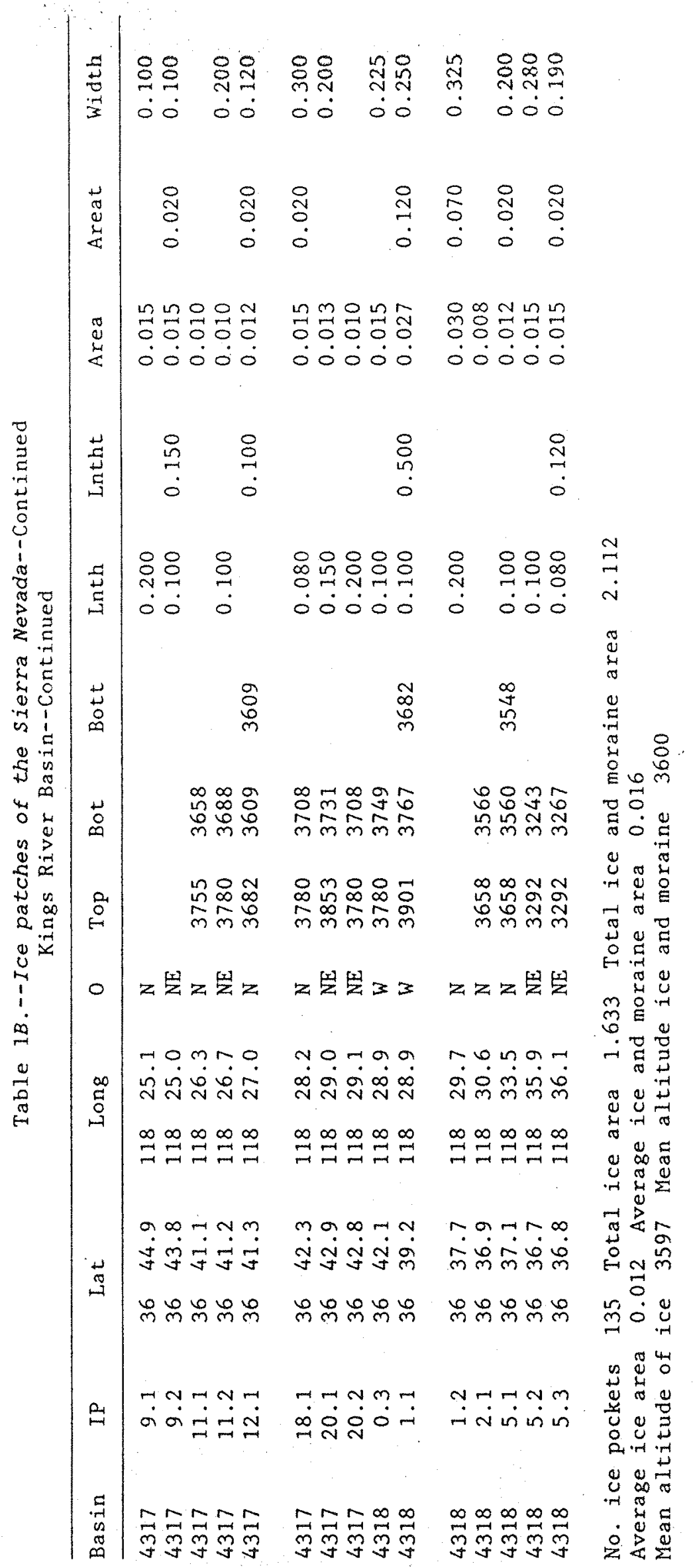




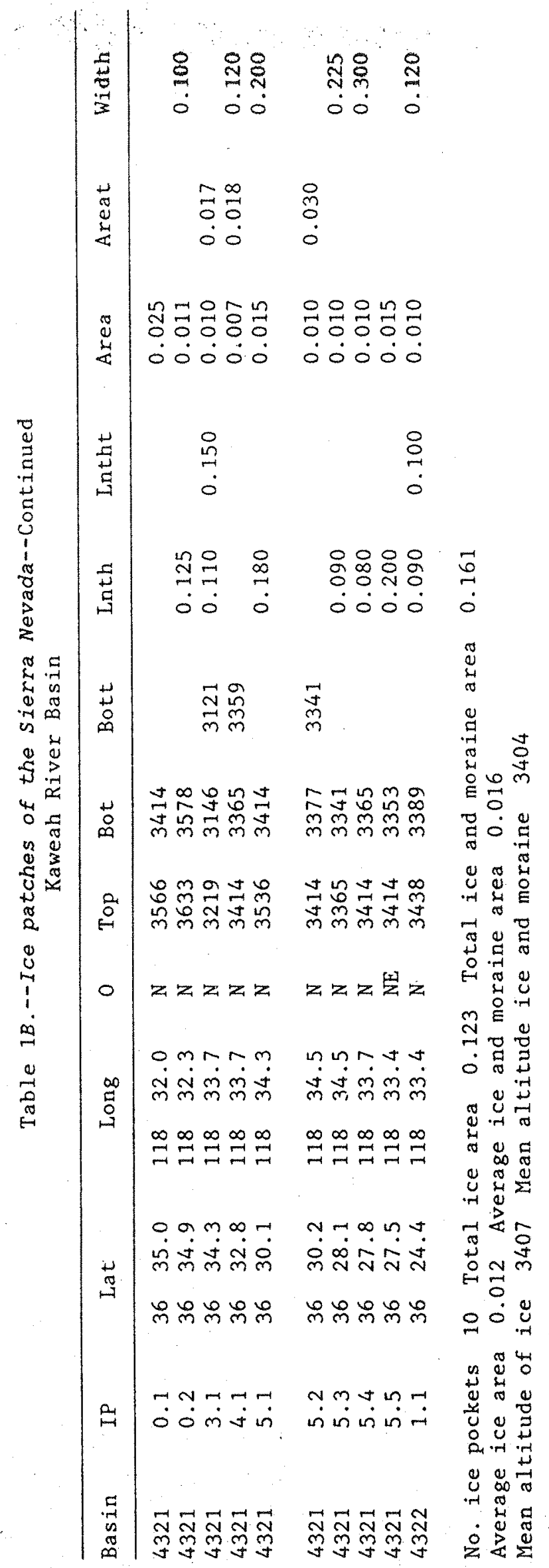




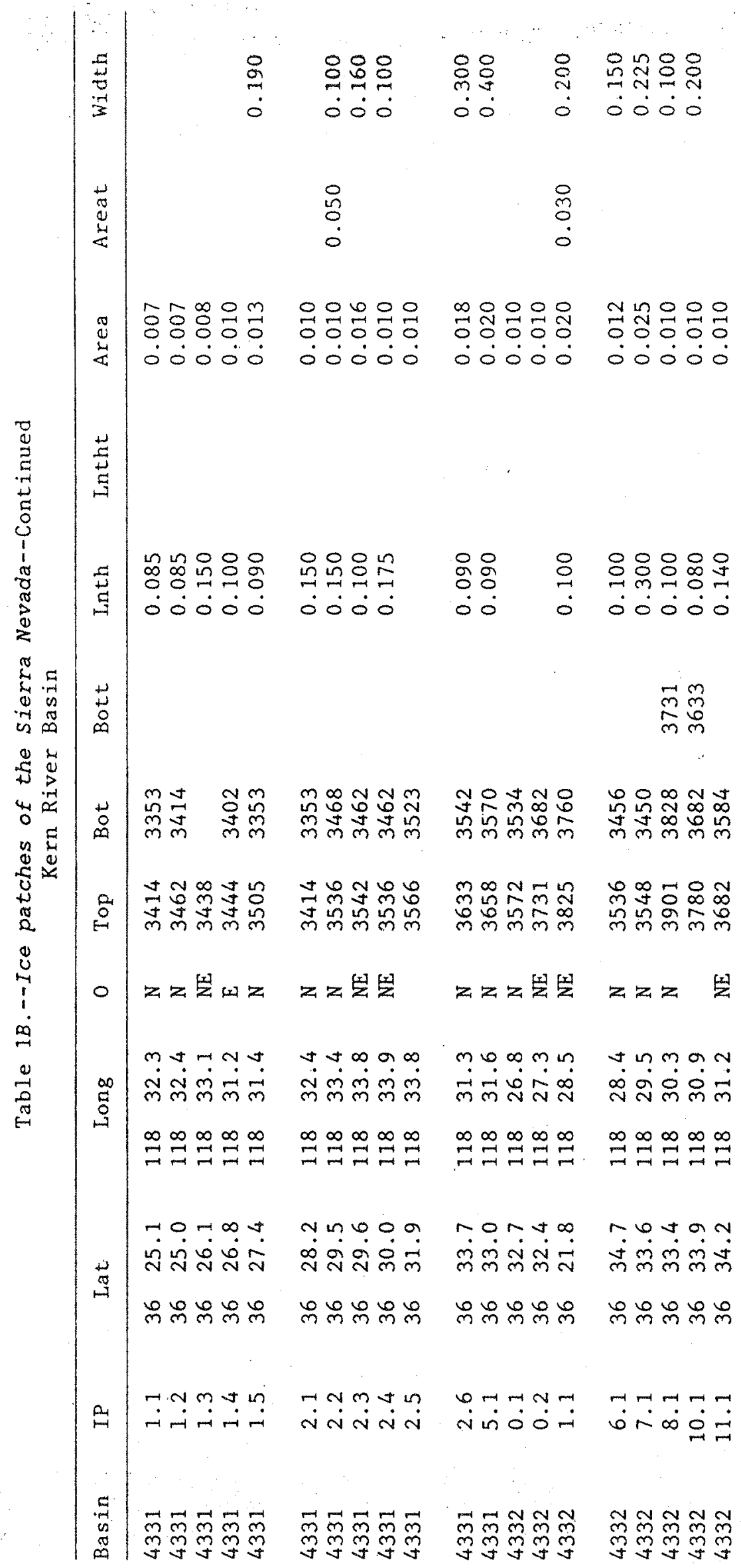




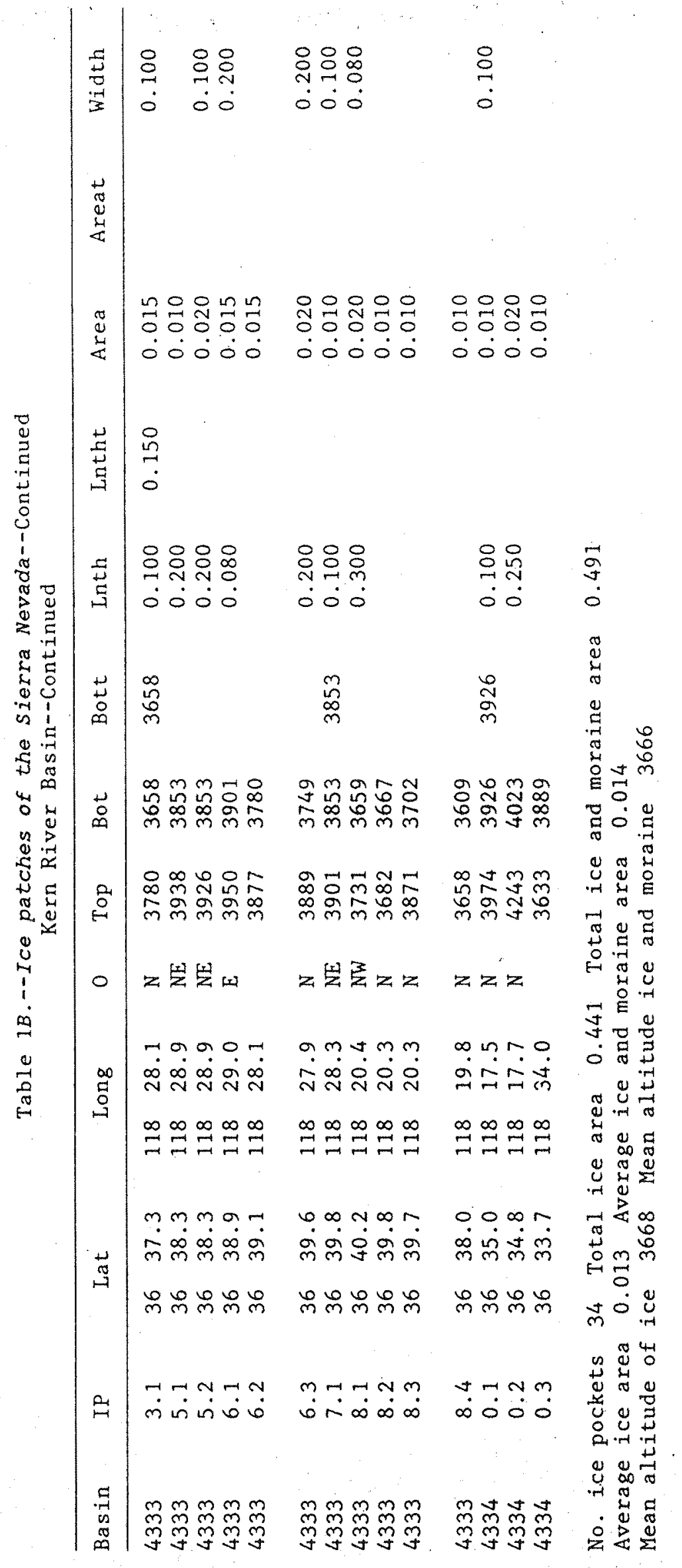


76 Inventory of Glaciers in the Sierra Nevada, California

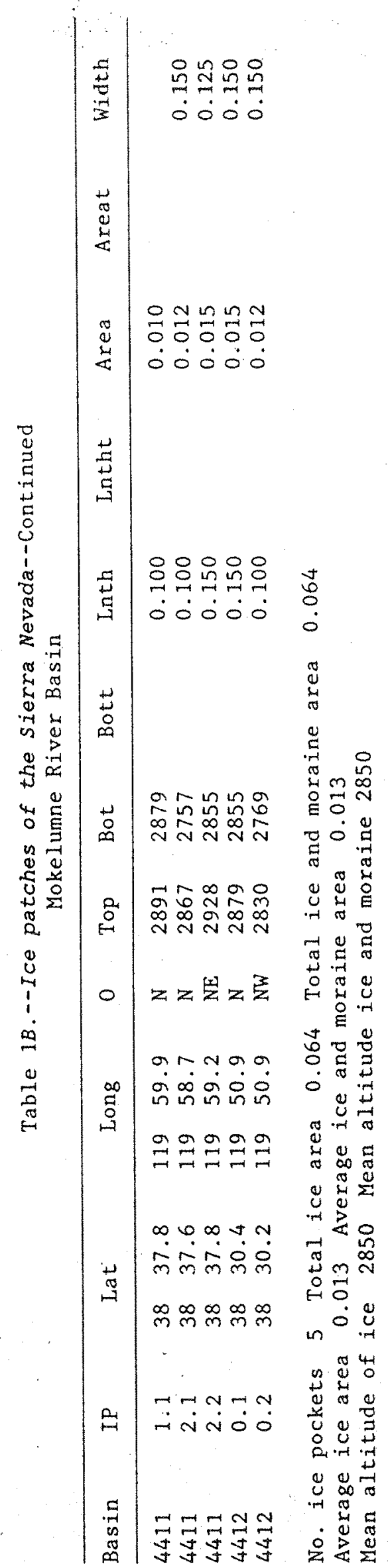




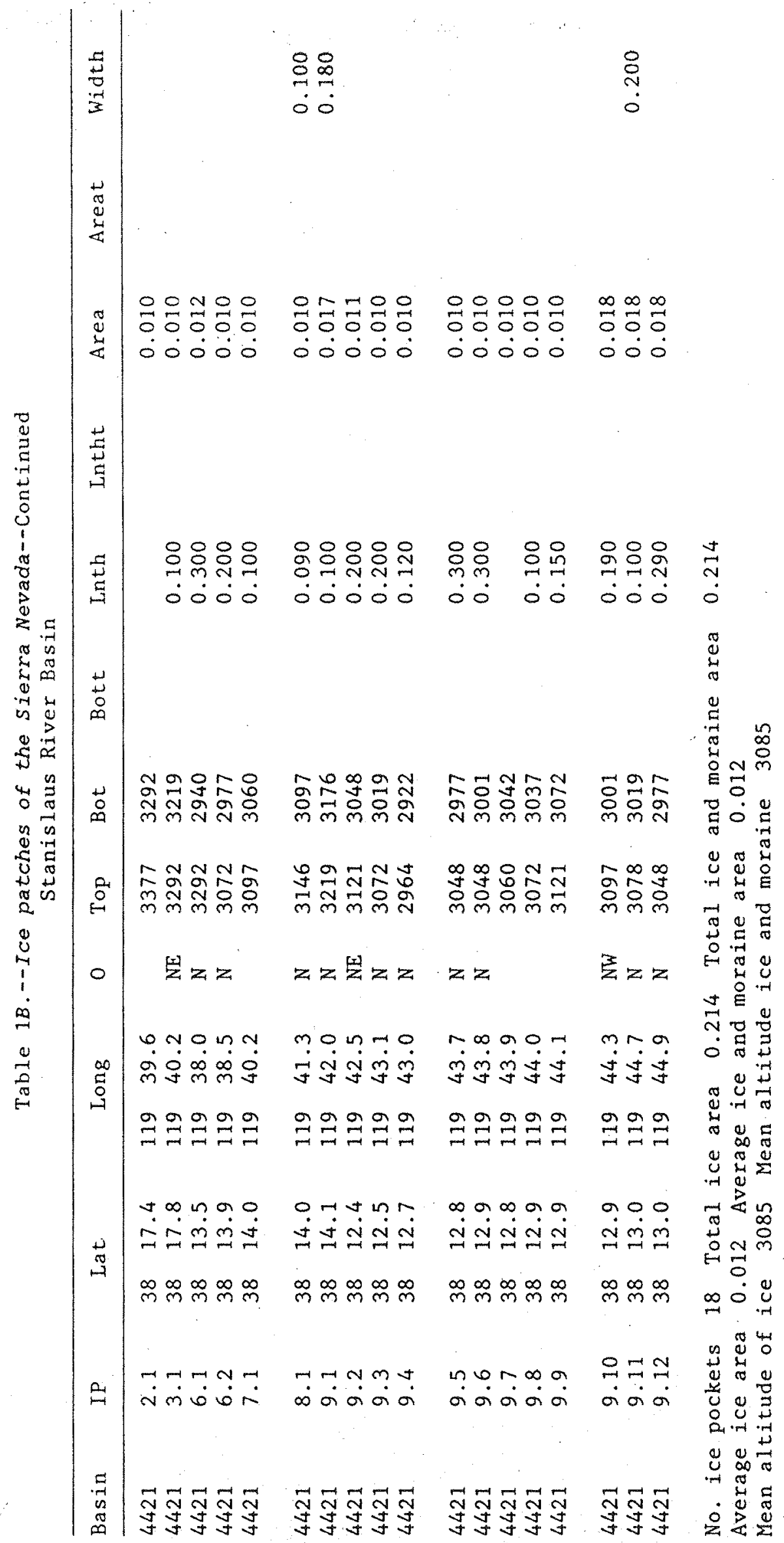




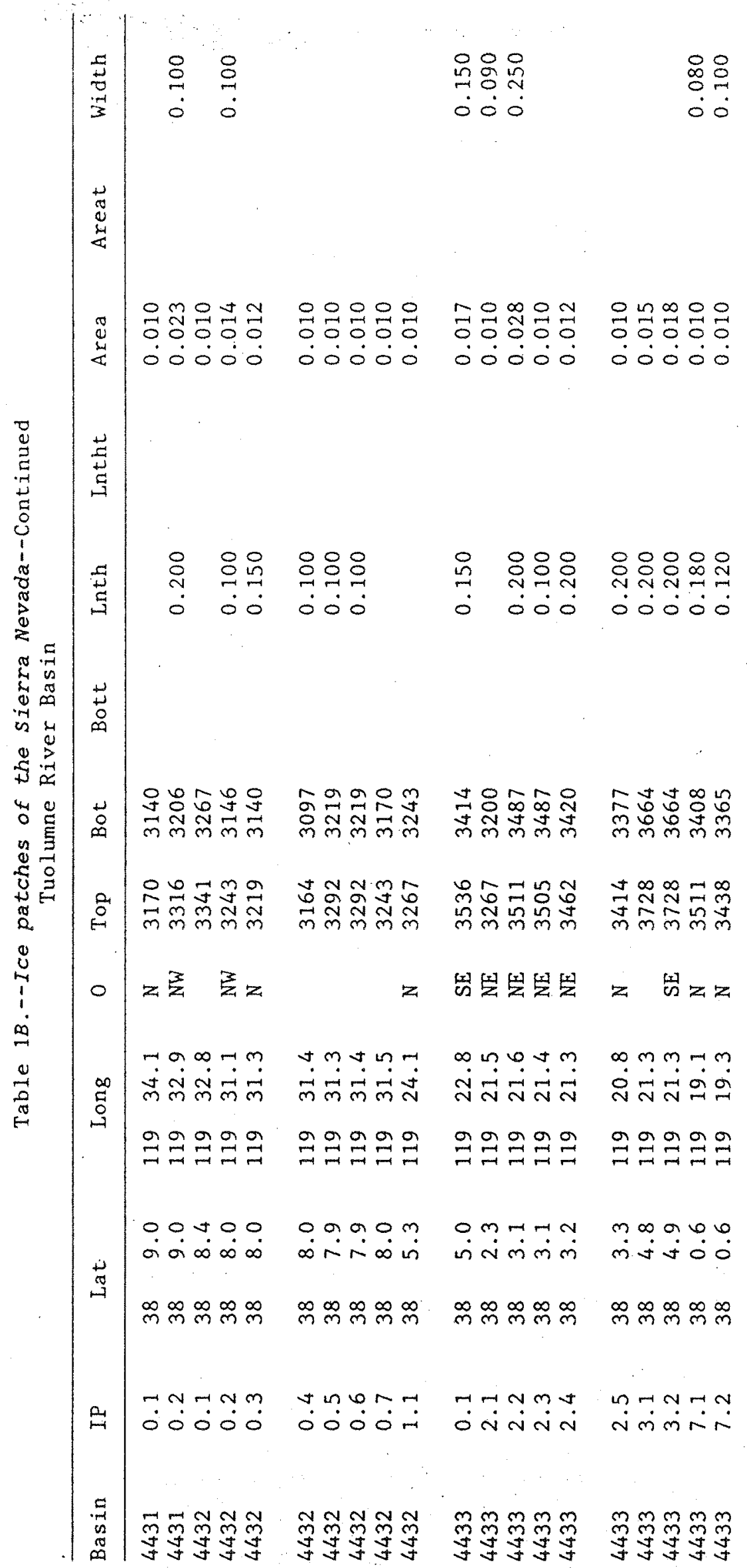




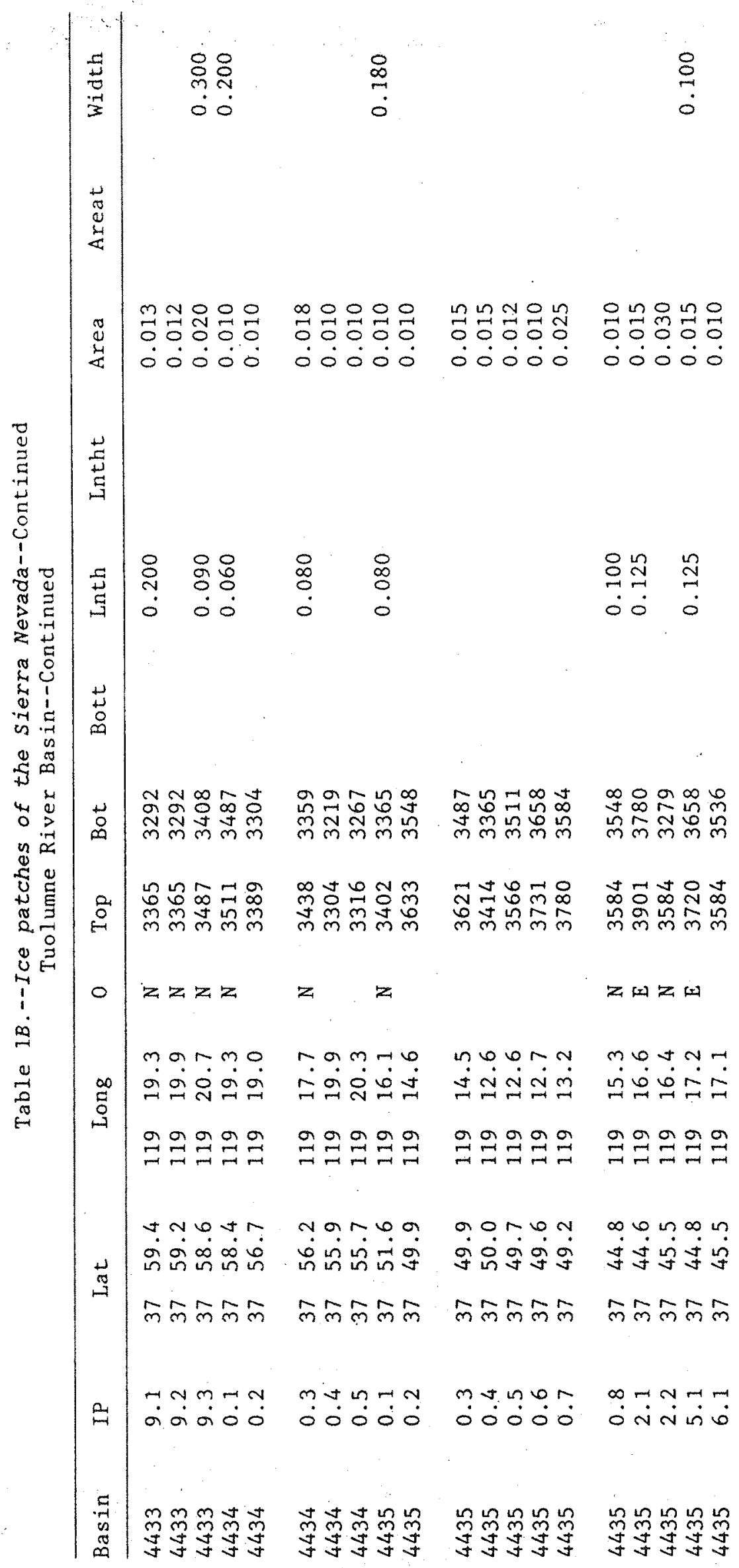




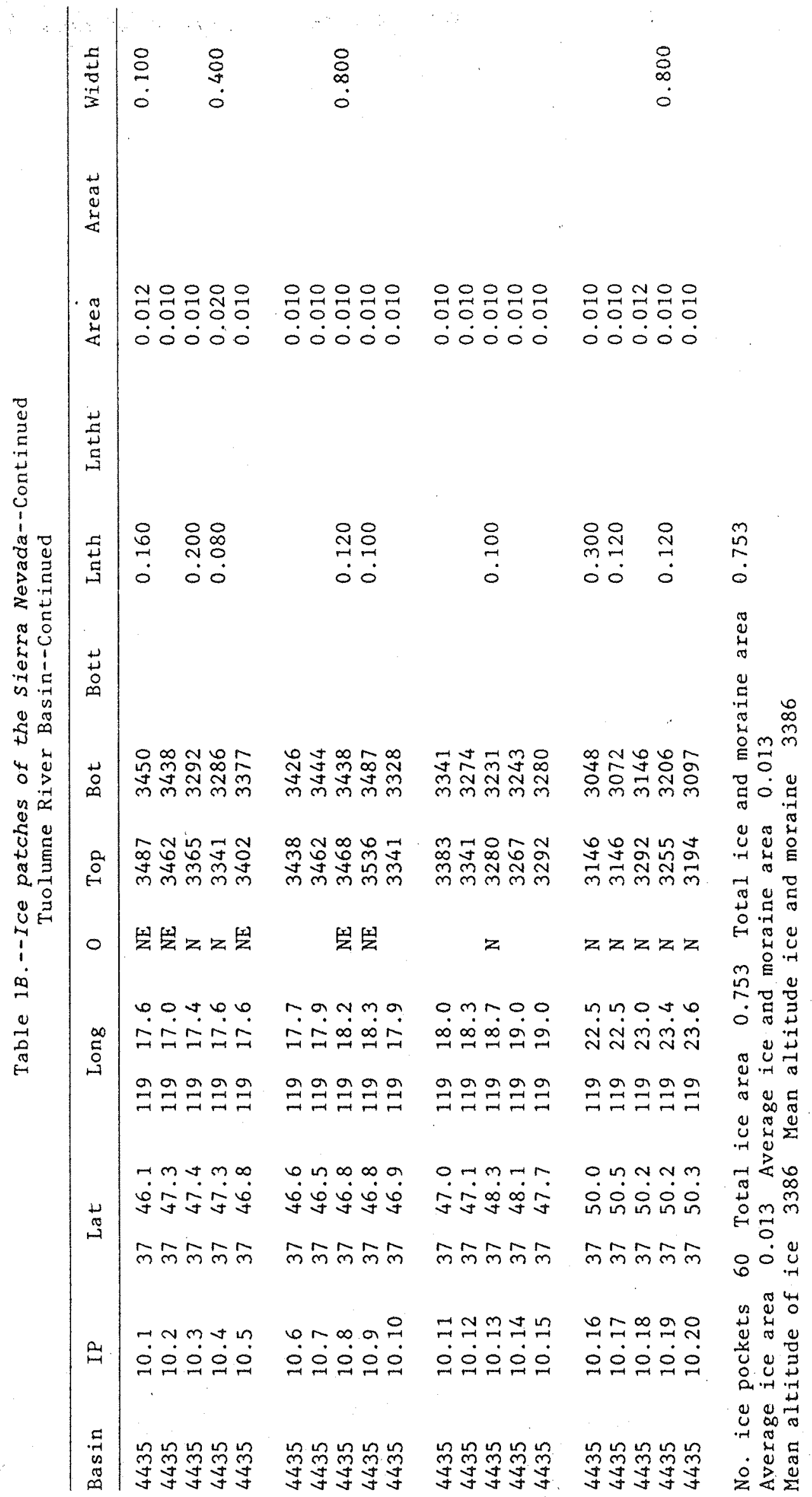




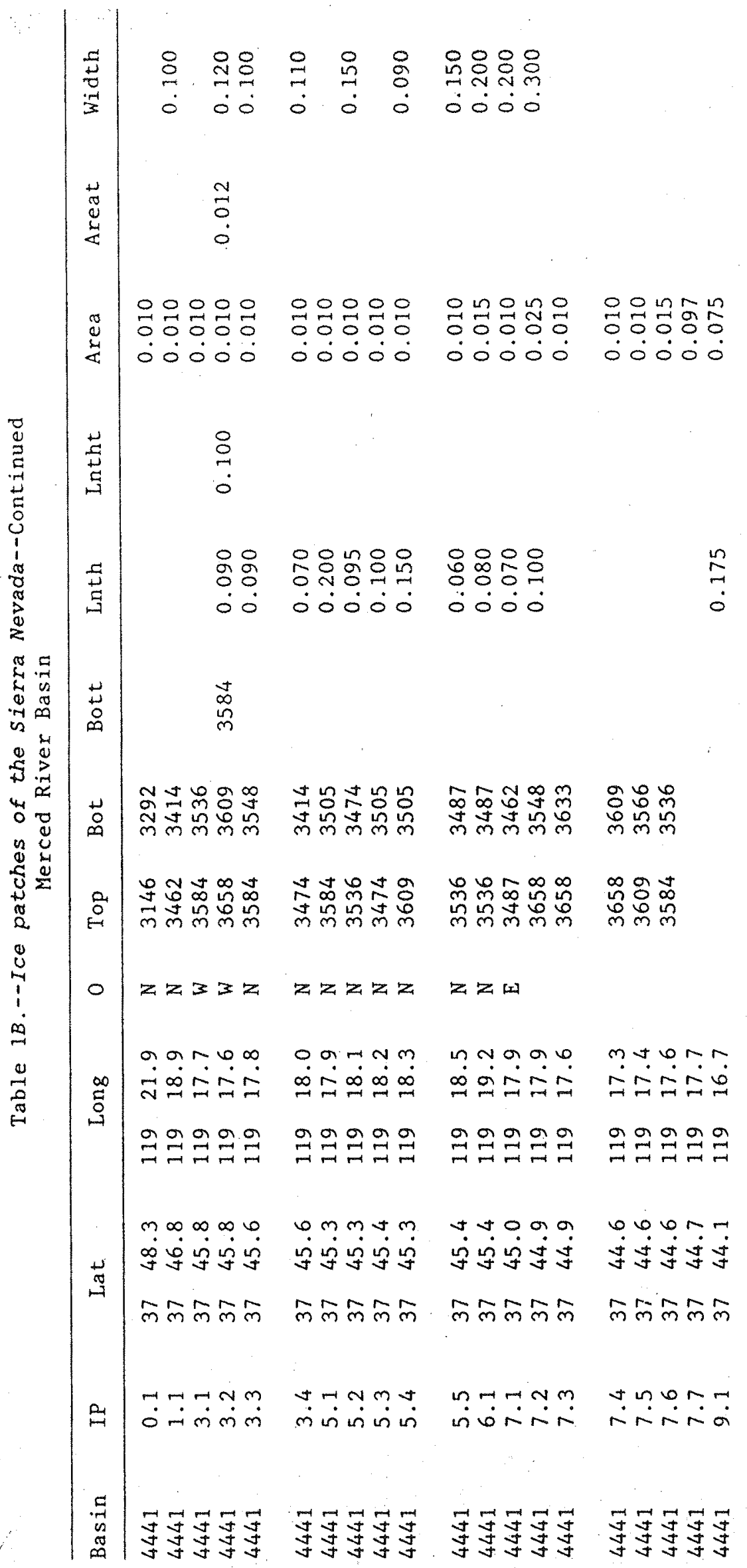




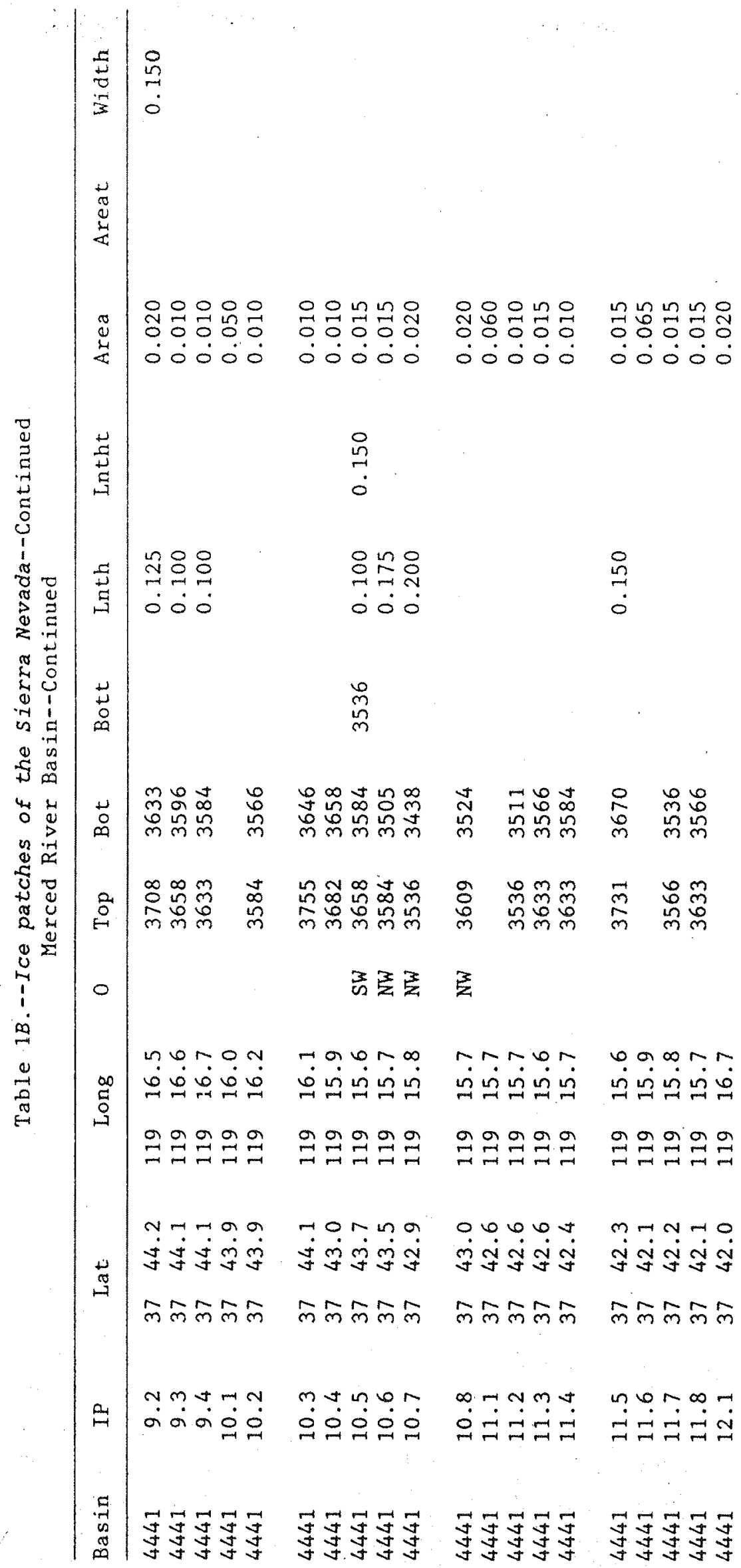




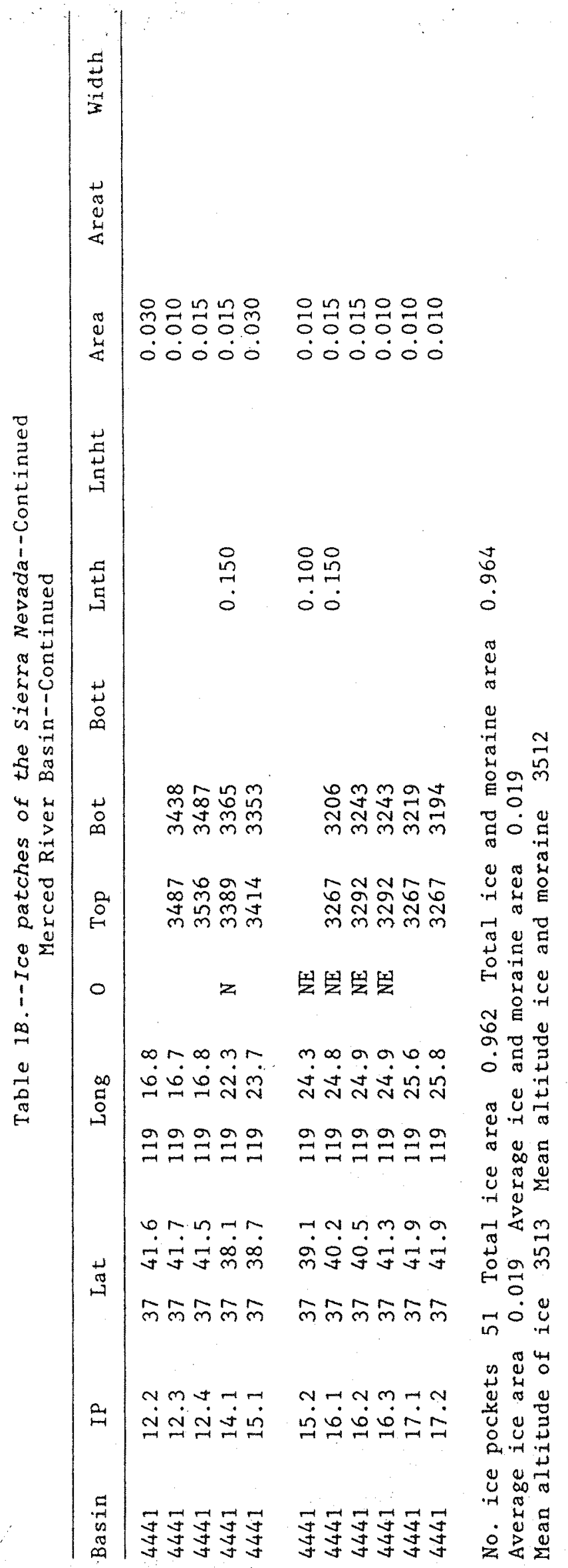




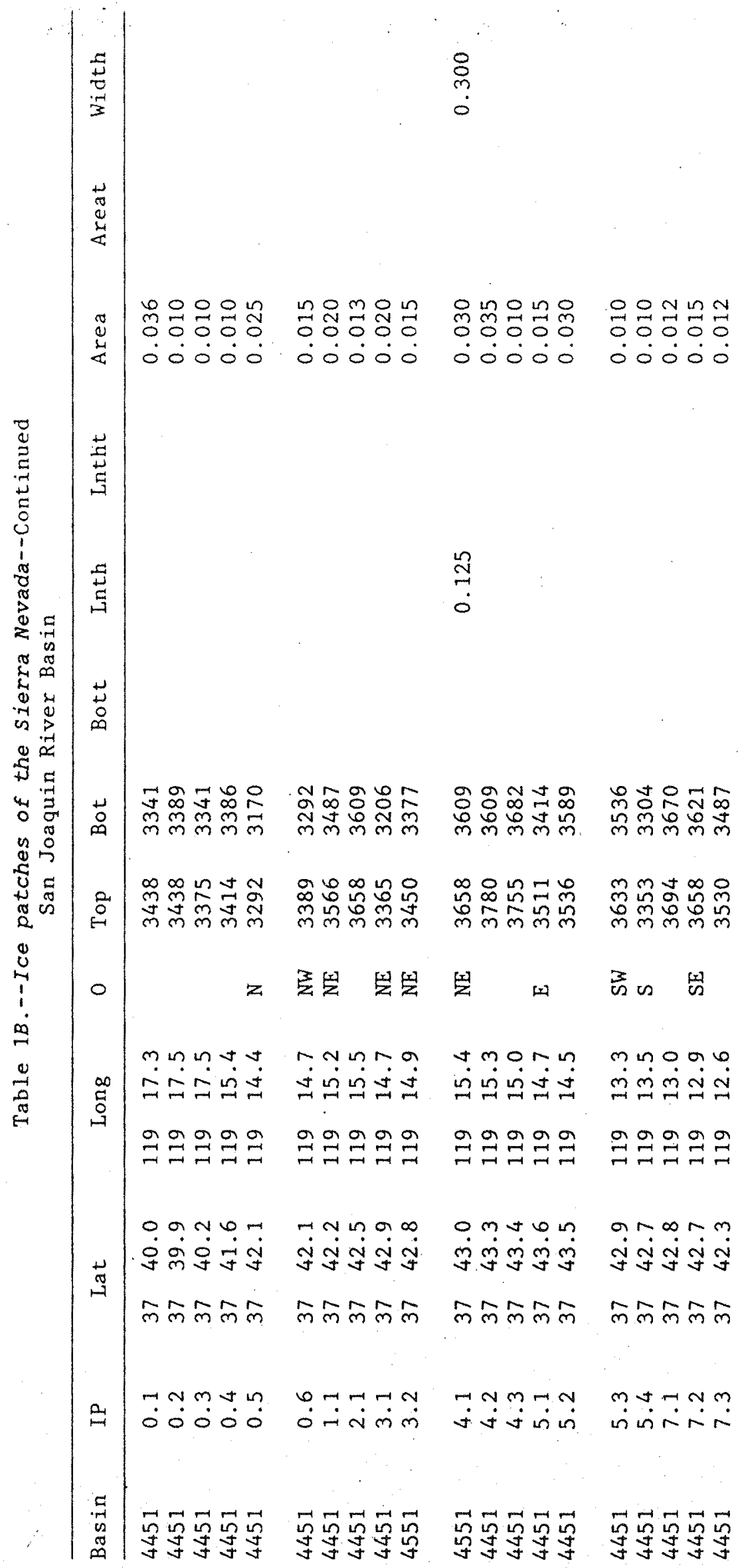




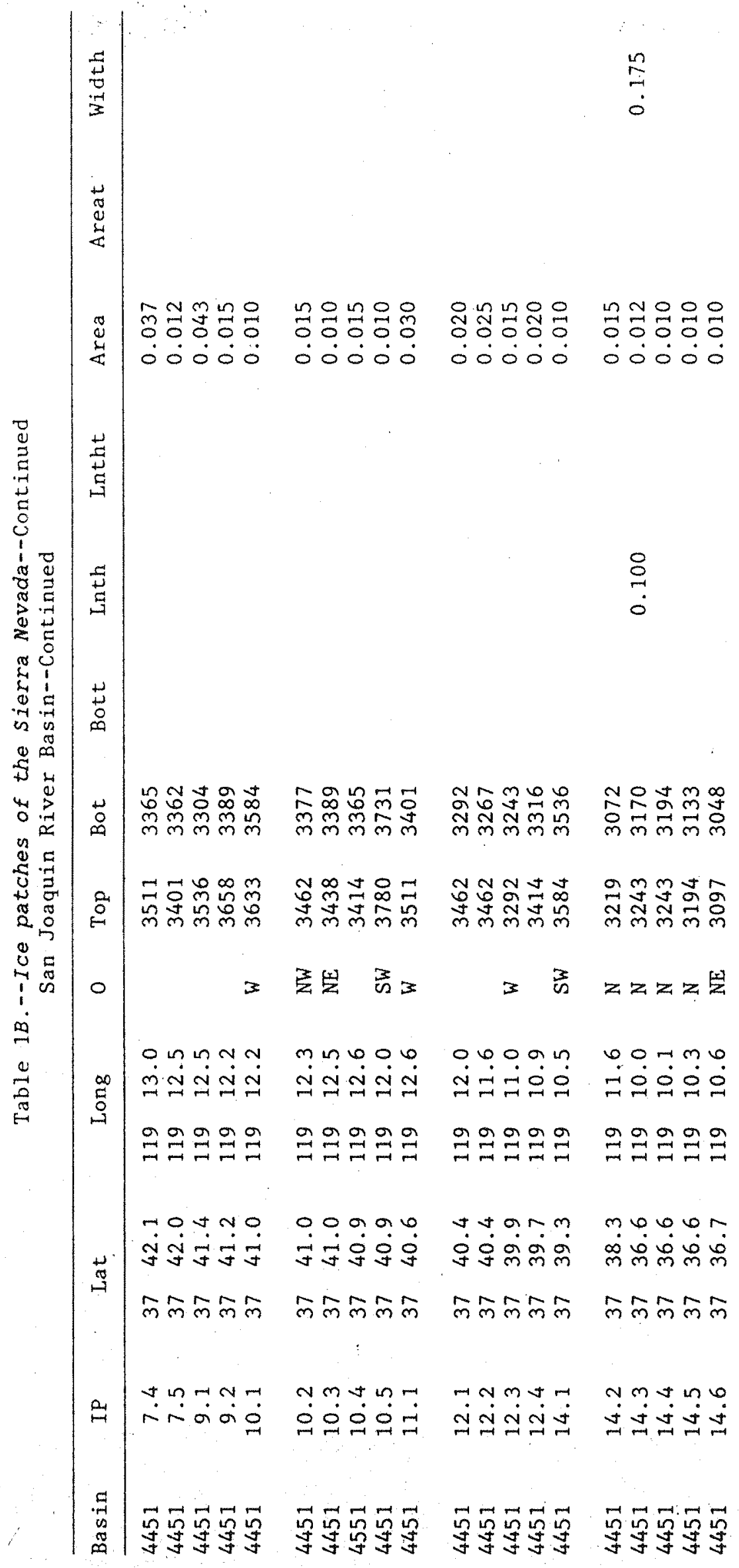




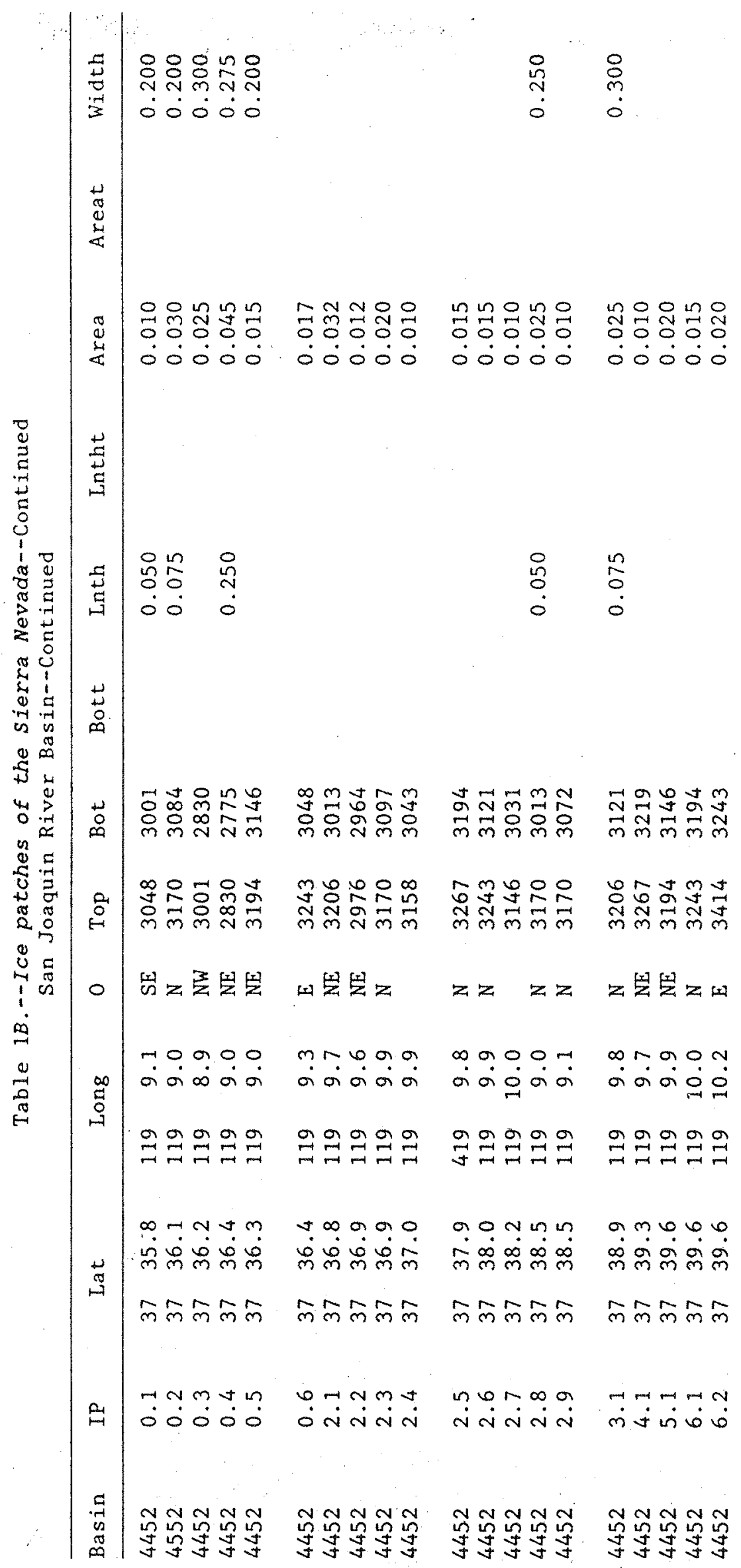




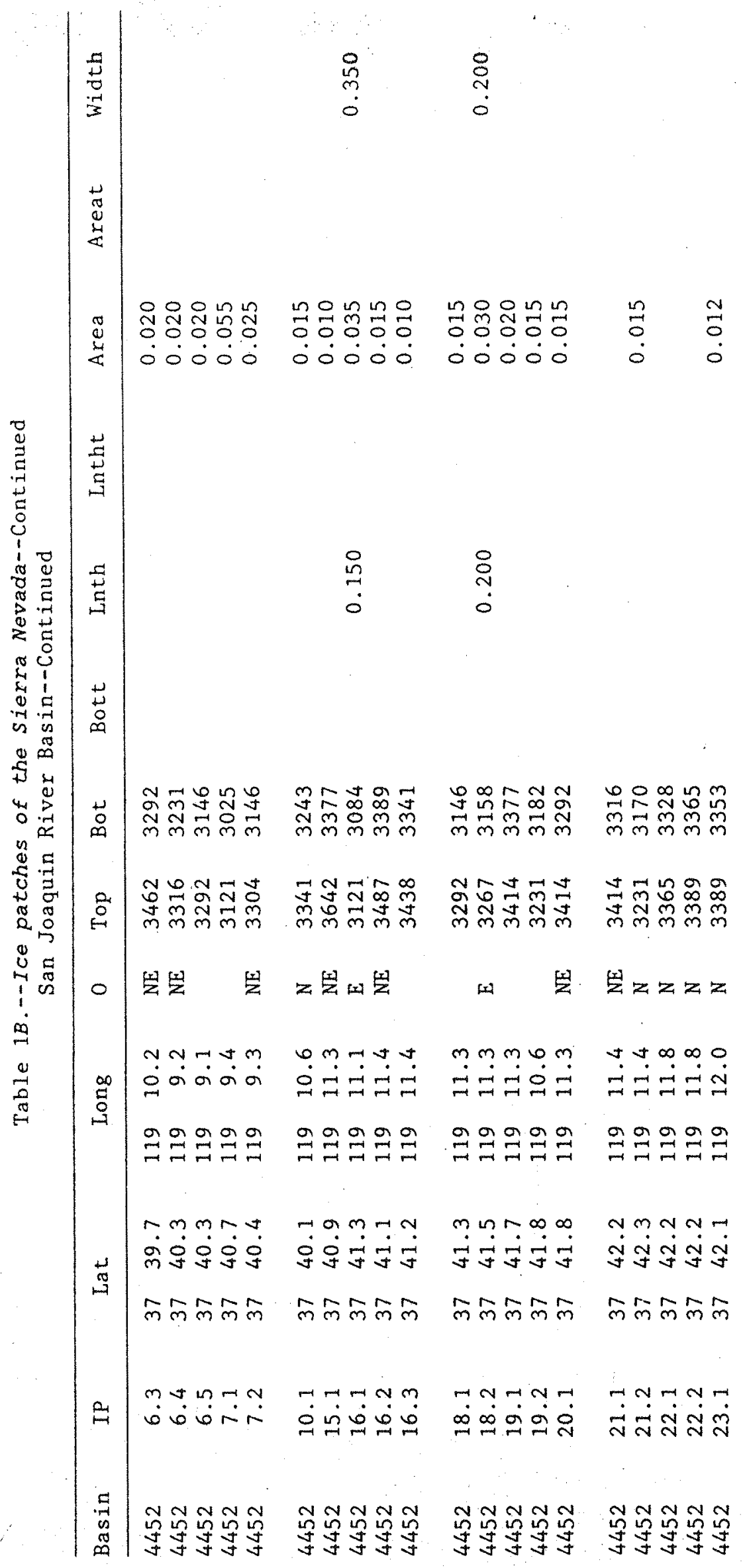




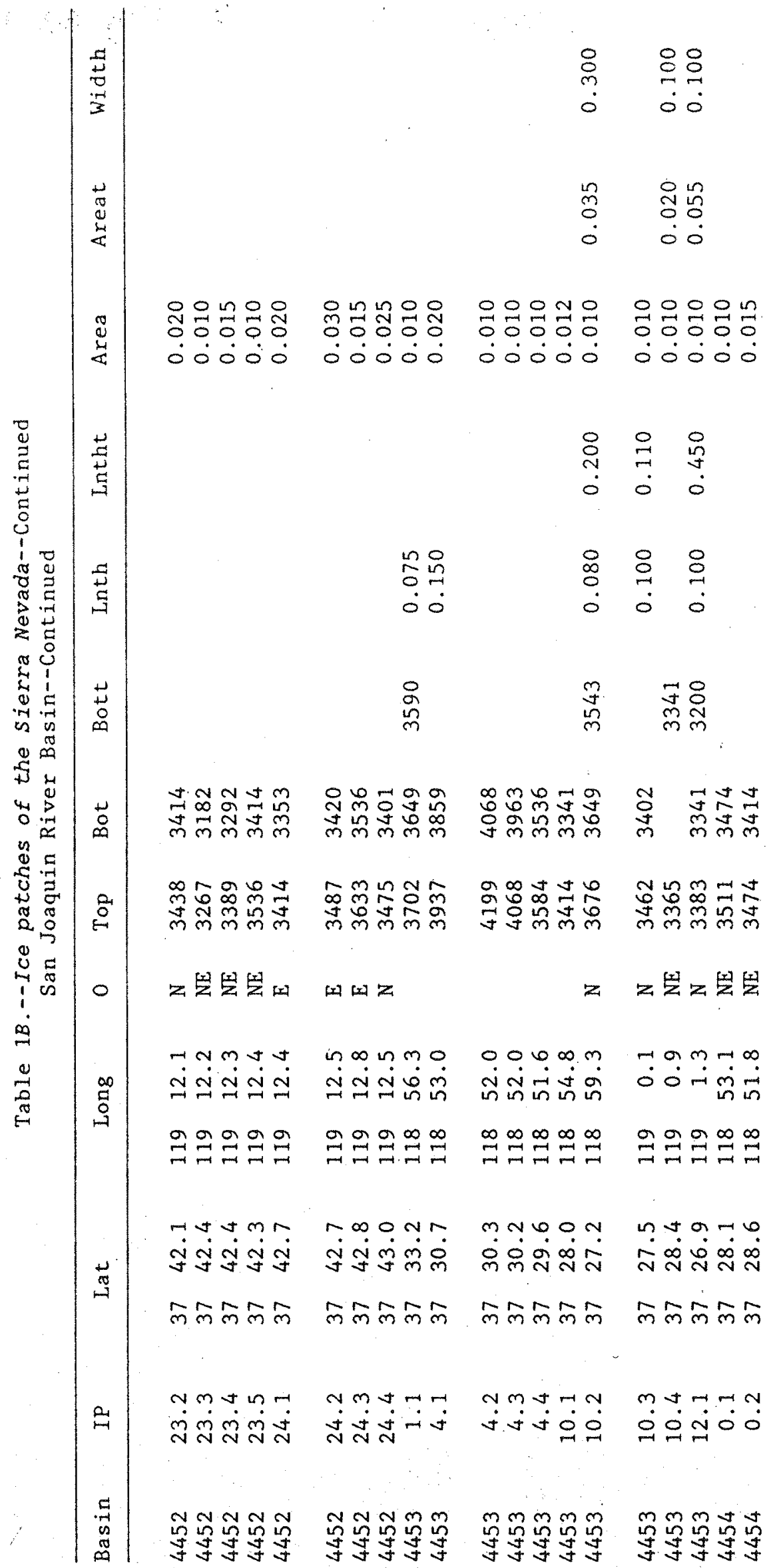




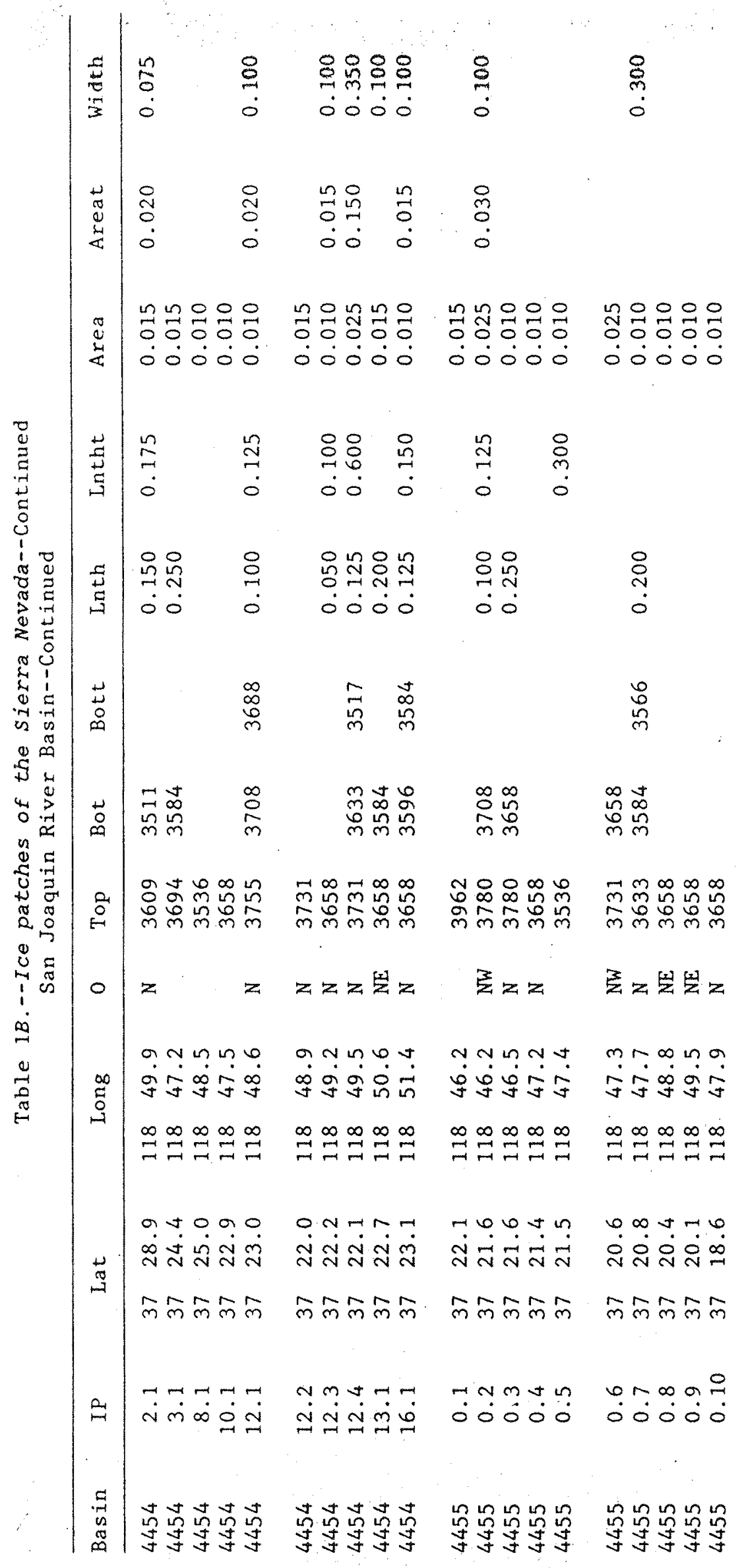




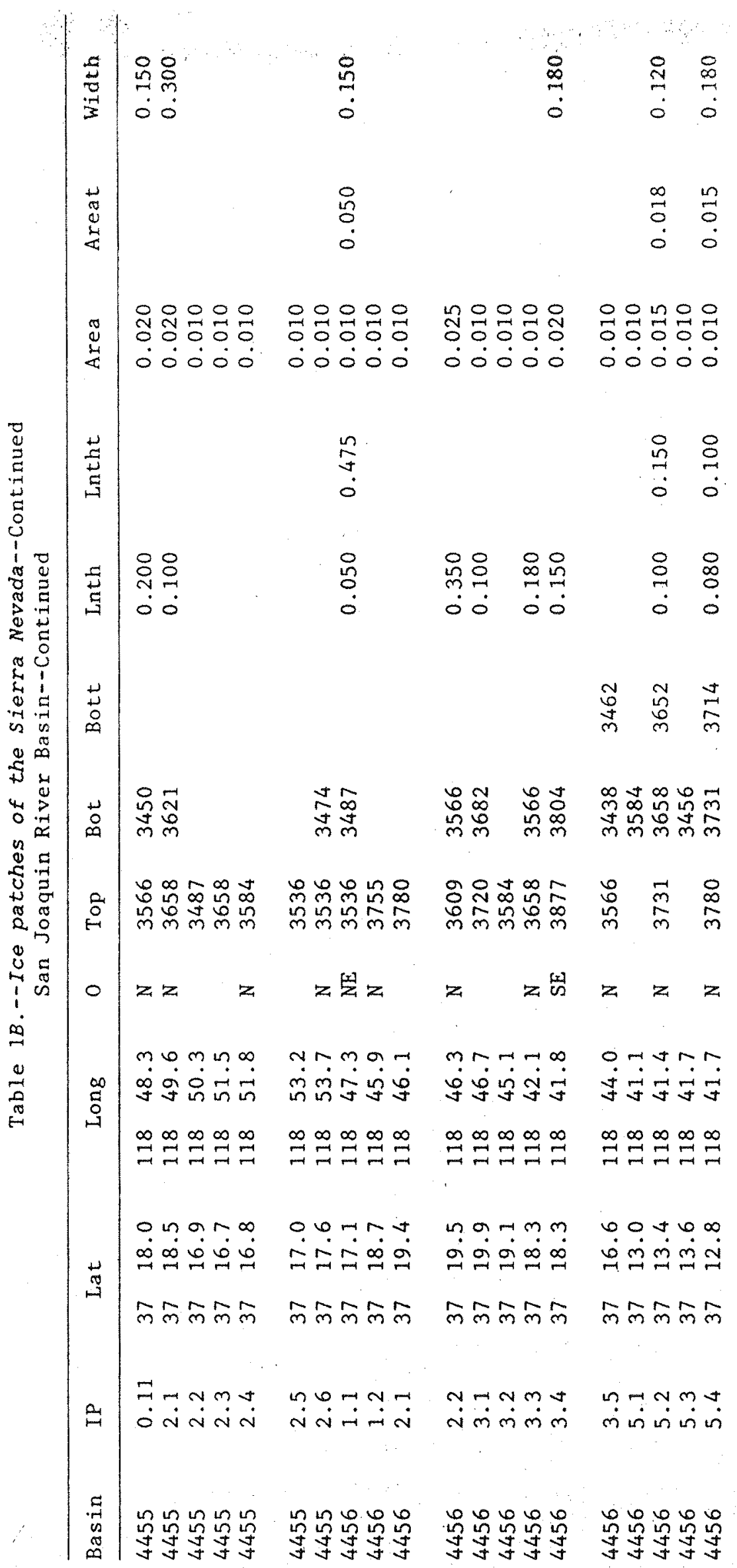




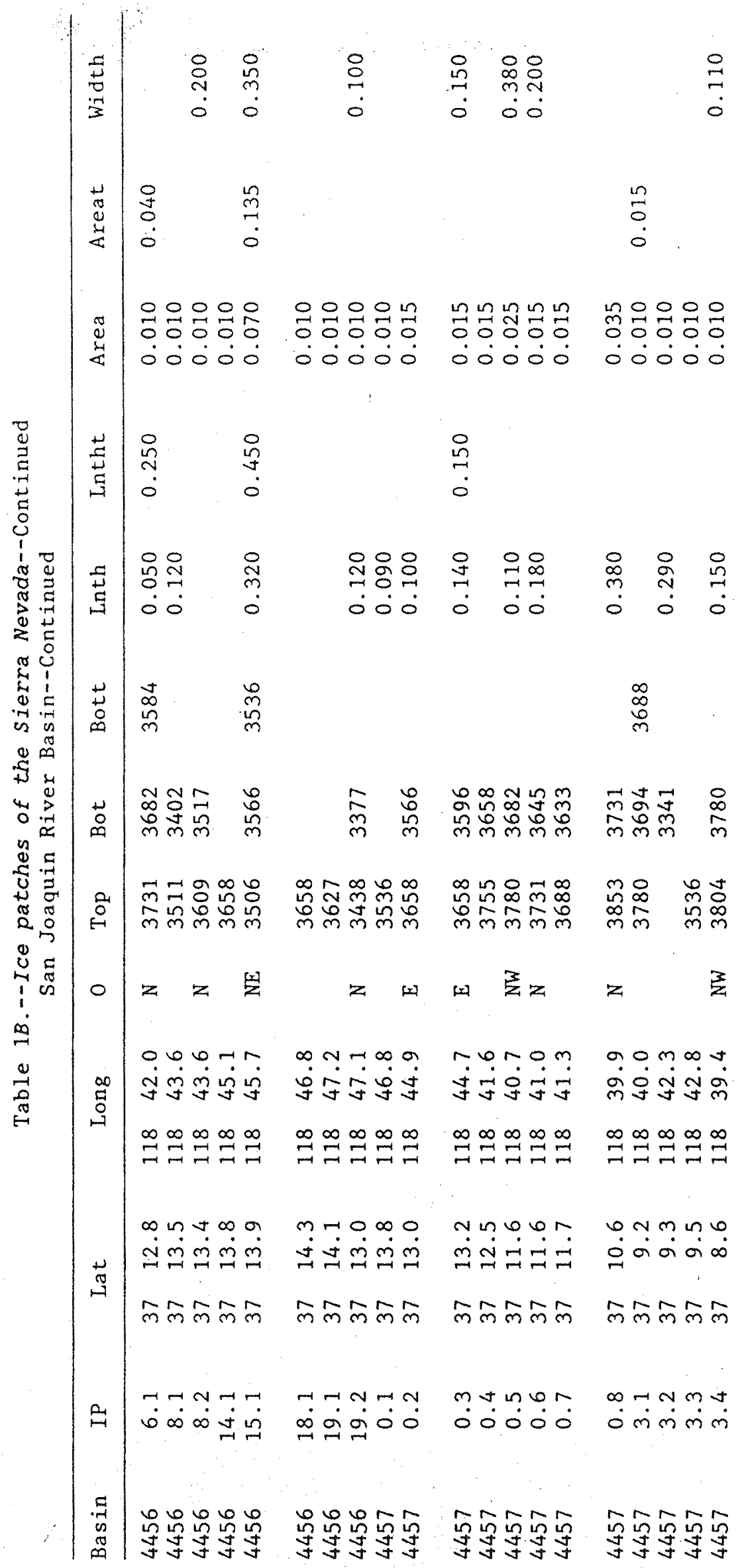




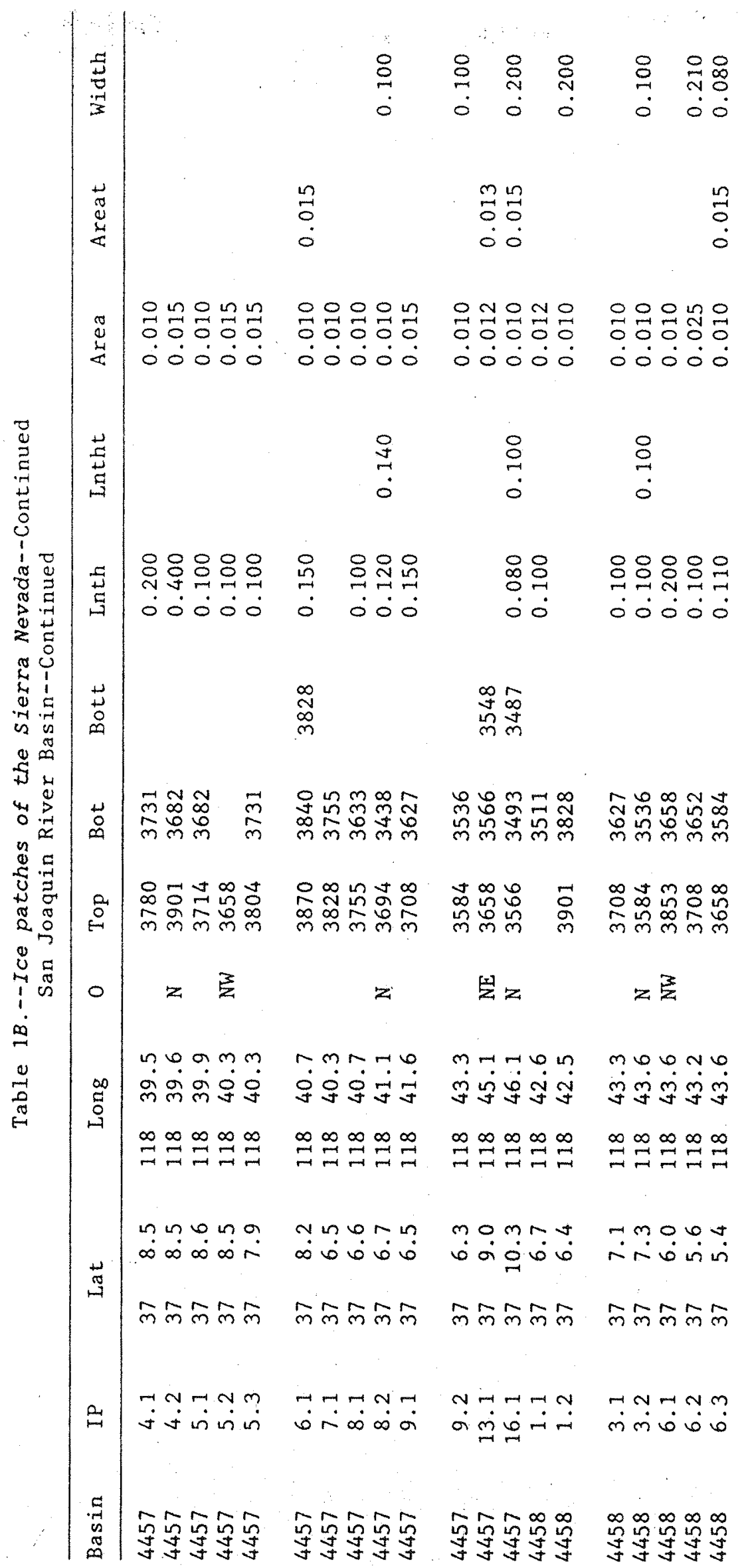




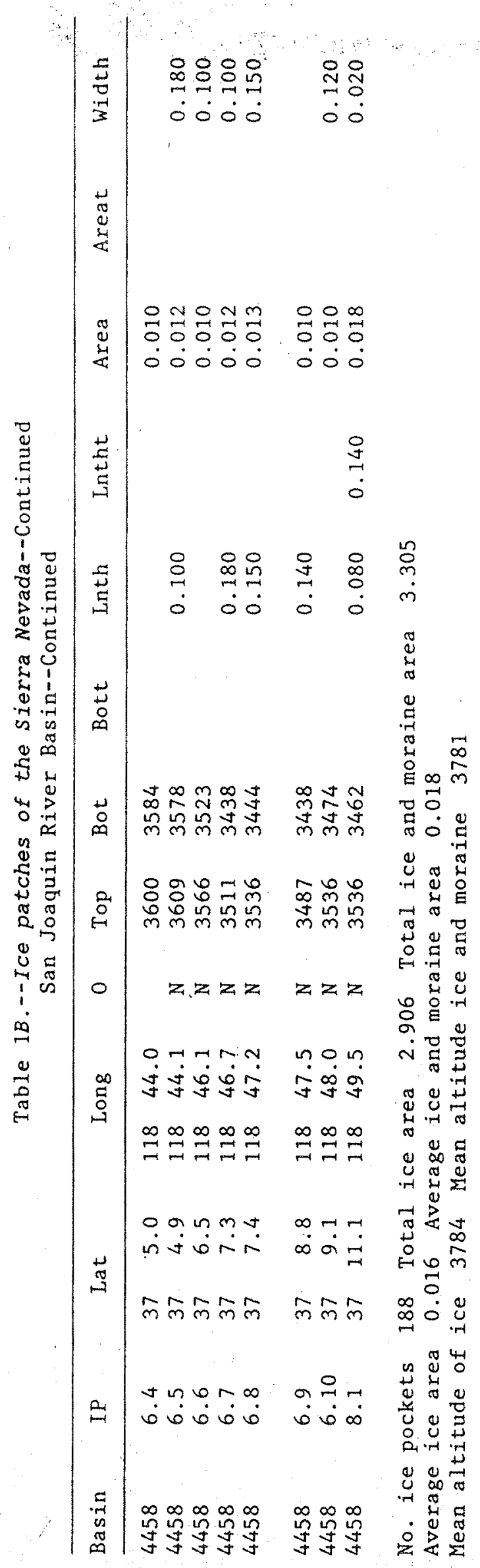


94 Inventory of Glaciers in the Sierra Nevada, California

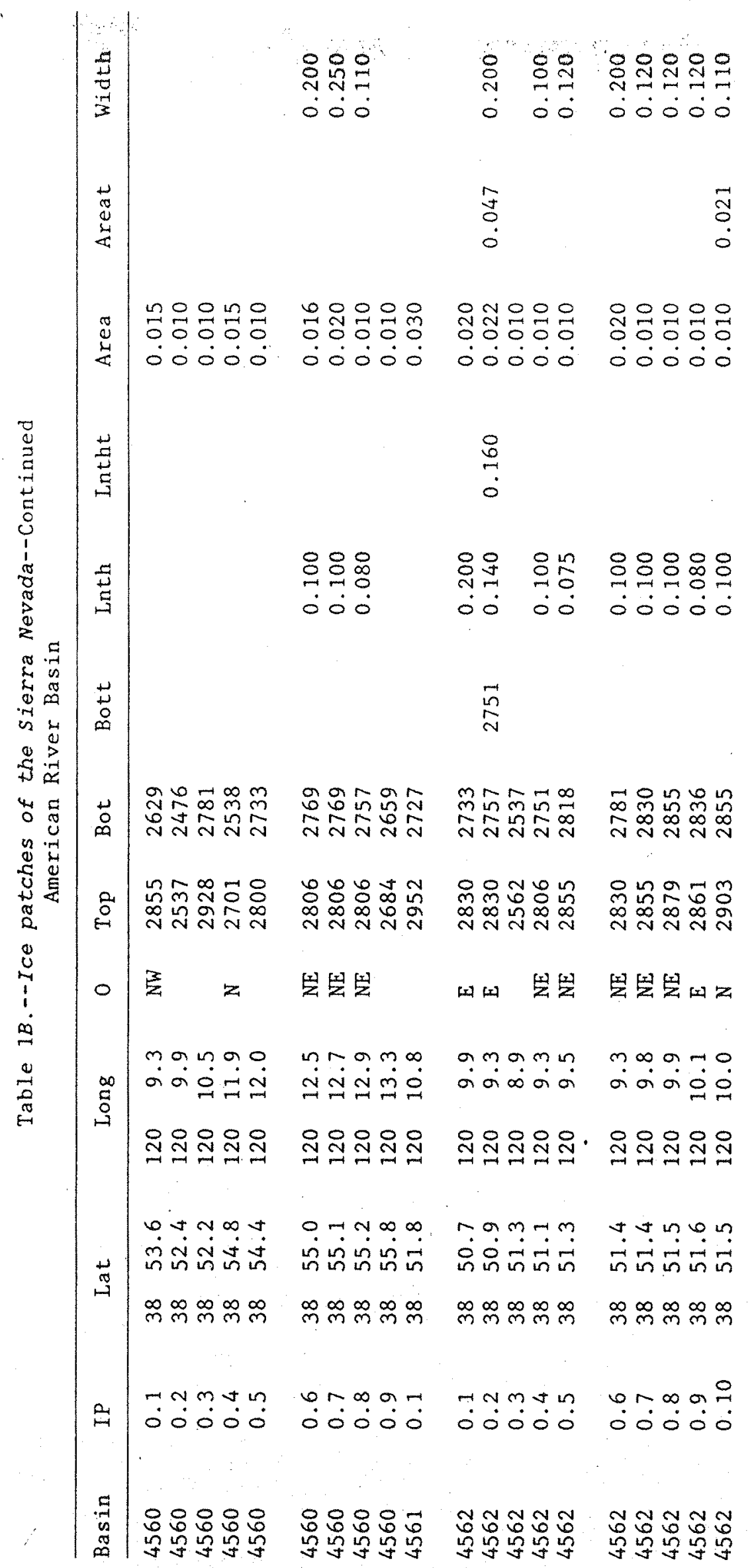




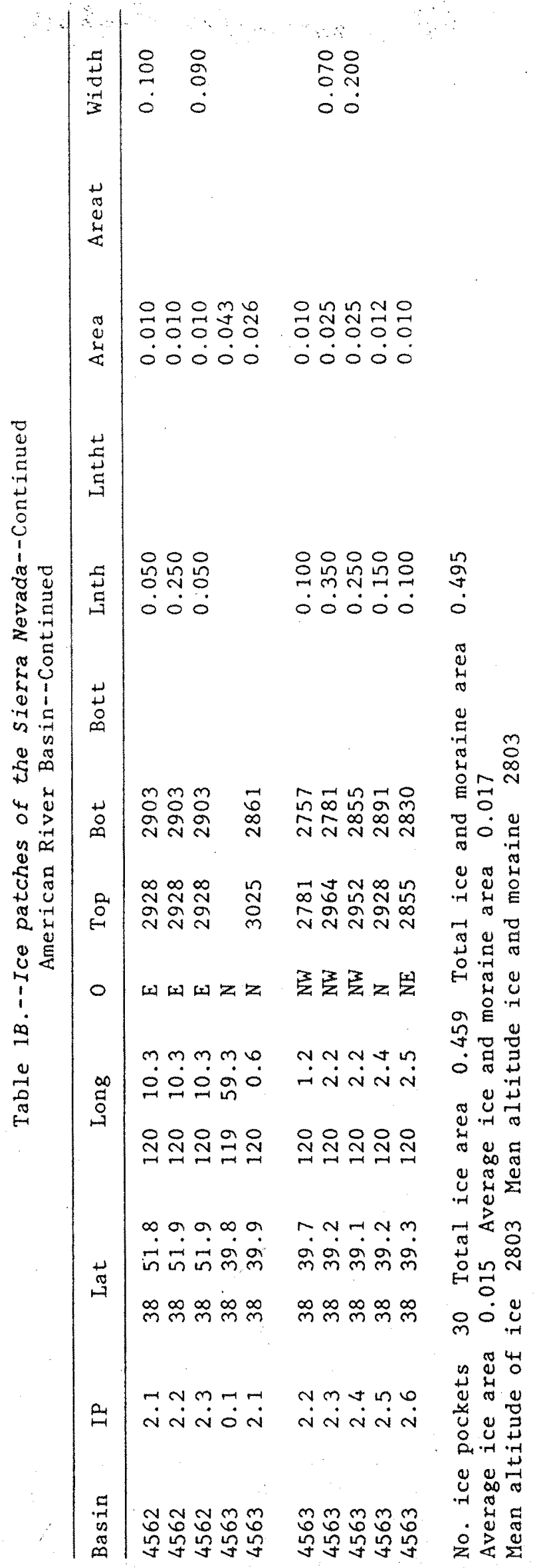


TABLE 1 Basin-Number-(BASIN) gives the glacier location in four digits, each denoting a subdivision as follows, from left to right (table 2):

First digit. The number 4 signifies the State of California.

Second digit. The major river basins are delineated as follows:

1 North Lahontan

2 South Lahontan

3 Tulare Lake

4 San Joaquin

5 Sacramento

Third digit. Indicates a secondary river basin (fig. 2). Fourth digit. Indicates a tertiary drainage basin of one or more smaller streams.

Appendix 2 lists the identification numbers used in this report and the equivalent International Identification Numbers to identify these glaciers in the world glacier inventory being assembled by the International Commission on Snow and Ice (ICSI).

Glacier-Number-(GL) refers to individual glaciers and ice patches numbered in a clockwise direction, in each tertiary sub-basin (pls. 2 and 4). The glaciers are assigned whole numbers. The ice patches are assigned decimal numbers relative to the glacier just previous to them following the clockwise system. If any ice patches appear in a basin before the first glacier, they are given a glacier number "0" (0.5). Note that the first ice patch relative to a glacier 7, for example, is numbered 7.1 and the tenth ice patch relative to that glacier is 7.10 . 
Latitude-and-Longitude-(LAT,-LONG) refer to the latitude $\left(60^{\circ} \mathrm{N}\right)$ and longitude $\left(60^{\circ} \mathrm{W}\right)$ of the glacier or ice patch in degrees, minutes, and tenths of minutes. The point of measurement is approximately the center of the ice.

Orientation-(0) of the glacier is based on an 8-point compass. The orientation represents an average where varying directions of flow were present. For glaciers in the Sierra Nevada, the orientation of the accumulation zone is almost always the same as the orientation of the ablation zone, thus an "average" is a reliable representation.

Top-Altitude-(TOP) is the altitude in meters of the highest point of the glacier or ice patch, not including snow chimneys.

Bottom-Altitude,-Exposed-Ice-(BOT) is the altitude in meters of the lowest point of exposed ice.

Bottom-Altitude,-Moraine-Covered-Ice-(BOTT) is the altitude in meters of the crest of the innermost ice-cored moraine. On many Sierra glaciers the moraine crest is higher than the exposed ice by $10-40 \mathrm{~m}$. For most ice patches, there is no moraine-covered ice and this is indicated by the absence of a value in this column.

Length,-Exposed-Ice-(LNTH) is the length in kilometers from the head of the glacier to the lower end of the exposed ice. 
Length,-Total-(LNTHT) is the length in kilometers from the head of the glacier to the crest of the innermost ice-cored moraine. Very few ice patches have a total length different from their exposed-ice length, and no value is given in those cases.

Area,-Exposed-(AREA) is the area in square kilometers of the exposed ice.

Area,-Tota1-(AREAT) is the area in square kilometers of exposed ice and moraine-covered ice. Very few ice patches have any debris-covered area.

Accuracy-(A) is the probable accuracy of the area, for glaciers only, defined in the following four categories:

1. Excellent: $0-5 \%$

2. Good: 6-10\%

3. Fair: 11-15\%

4. Approximate: $16-25 \%$

Width-(WIDTH) refers to the width of the headwall in meters.

Classification-(CLASS) of the glaciers only is given by a series of eight digits, explained in table 3 .

Glacier-Names-(GL-NAME), both official and unofficial are given. Unofficial names are placed in parentheses. 
Table 2.--Sierra Nevada river basin divisions and inventory identification numbers.

\begin{tabular}{|c|c|c|c|c|}
\hline Sub & $\begin{array}{l}\text { Major Basin } \\
\text { Basin }\end{array}$ & $\begin{array}{l}\text { Secondary } \\
\text { Rịver Basin }\end{array}$ & $\begin{array}{l}\text { Assigned } \\
\text { Basin Number }\end{array}$ & Tertiary \\
\hline \multirow{4}{*}{\multicolumn{2}{|c|}{$\begin{array}{l}\text { NORTH } \\
\text { LAHONTAN }\end{array}$}} & East Carson & 411 & 1,2 \\
\hline & & & & \\
\hline & & West Walker & 412 & 1,2 \\
\hline & & East Walker & 413 & $1,2,3$ \\
\hline & SOUTH & Owens & 421 & $1,2,3,4,5,6,7$ \\
\hline & LAHONTAN & Mono & 422 & $1,2,3,4$ \\
\hline & TULARE & Kings & 431 & $1,2,3,4,5,6,7,8$ \\
\hline \multirow{2}{*}{\multicolumn{2}{|c|}{ LAKE }} & Kaweah & 432 & 1,2 \\
\hline & & Kern & 433 & $1,2,3,4$ \\
\hline \multirow{5}{*}{\multicolumn{2}{|c|}{ SAN JOAQUIN }} & Mokelumne & 441 & 1 \\
\hline & & Stanislaus & 442 & 1 \\
\hline & & Tuolumne & 443 & $1,2,3,4,5$ \\
\hline & & Merced & 444 & 1,2 \\
\hline & & San Joaquin & 445 & $1,2,3,4,5,6,7,8$ \\
\hline & SACRAMENTO & American & 456 & $1,2,3$ \\
\hline
\end{tabular}




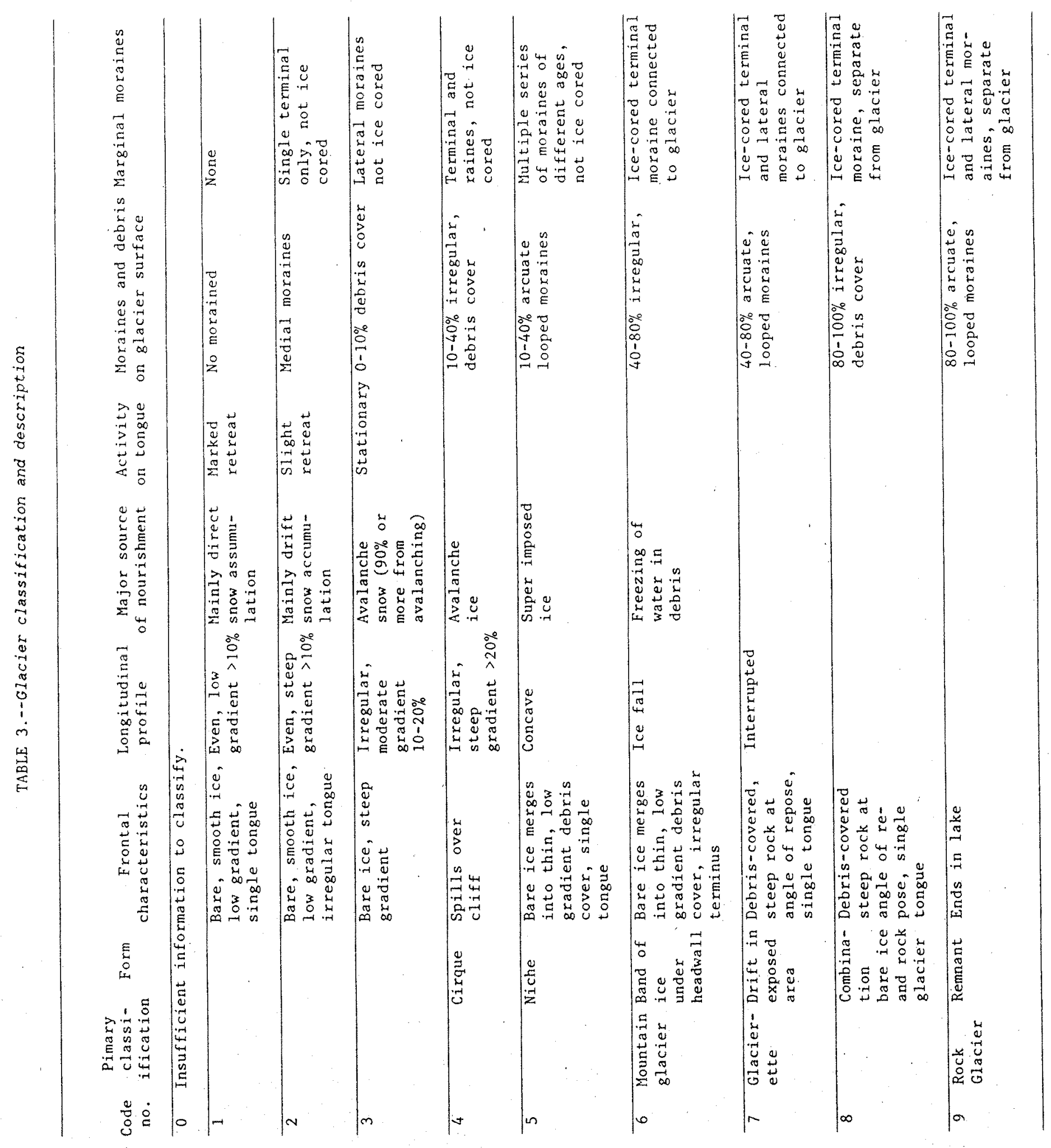




\section{RESULTS OF THE INVENTORY}

Previous estimates of the number of glaciers in all of California were between 80 and 100 (Dean, $1974 \mathrm{Hill}$, 1975b), with a total area of 20 $\mathrm{km}^{2}$ (Dean, 1974). The present inventory lists many more glaciers in the Sierra Nevada alone this is due to including smaller glaciers than in former compilations as well as many previously unidentified glaciers as the result of new and better mapping techniques. Listed in this inventory are 497 glaciers and 788 ice patches with an exposed ice area of $35 \mathrm{~km}^{2}$, and a total (exposed ice plus moraine-covered ice) area of $63 \mathrm{~km}^{2}$, (table 4) the glaciers alone have a total area of $50 \mathrm{~km}^{2}$ (tables 4 and 5). East of the crest of the Sierra Nevada 198 glaciers with a total area of about $25 \mathrm{~km}^{2}$ are identified; 124 of these are in the Owens basin. West of the crest, 299 glaciers with a total area of slightly less than $25 \mathrm{~km}^{2}$ drain into 13 river basins. The largest glaciers $\left(>0.3 \mathrm{~km}^{2}\right)$ represent only 5 percent of the number of glaciers, but account for 20 percent of the total glacierized area. The Palisade Glacier (非214 11, pls. 3 and 4 ) is the largest Sierra Nevada glacier, with a total area of $1.6 \mathrm{~km}^{2}$ the smallest glacier (非121 5, pls. 1 and 2) has an area of $0.01 \mathrm{~km}^{2}$. In the North Cascade glacier inventory (Post and others, 1971), each size class contributed a roughly equal share to the total glacier area this relationship does not exist with the Sierra Nevada glaciers (figs. 3 and 4). Fifty-two rock glaciers with a total area of $5 \mathrm{~km}^{2}$ were identified, 28 of them in the Owens basin. More rock glaciers doubtless exist, but they were observed only in the vicinity where exposed-ice glaciers were studied. 
102 Inventory of Glaciers in the Sierra Nevada, California

Table 4.--Sumnary of data for Sierra Nevada glaciers and ice patches. "Total area" refers to exposed ice plus moraine-covered ice.

\section{GLACIERS}

Number

Area exposed ice

Total area

Weighted mean altitude

497

$24.1 \mathrm{~km}^{2}$

$49.6 \mathrm{~km}^{2}$

$3,543 \mathrm{~m}$

ICE PATCHES

Number

788

Area exposed ice/snow

Total area

Weighted mean altitude

$11.0 \mathrm{~km}^{2}$

$13.3 \mathrm{~km}^{2}$

$3,492 \mathrm{~m}$ 
Table 5.--Glacier data by basin.

\begin{tabular}{|c|c|c|c|c|c|c|}
\hline $\begin{array}{l}\text { Basin } \\
\text { No. }\end{array}$ & $\begin{array}{l}\text { Basin } \\
\text { Name }\end{array}$ & $\begin{array}{l}\text { Number of } \\
\text { Glaciers }\end{array}$ & $\begin{array}{l}\text { Latitude } \\
\left({ }^{\circ} \mathrm{N}\right)\end{array}$ & $\begin{array}{l}\text { Longitude } \\
\left({ }^{\circ} \mathrm{W}\right)\end{array}$ & $\begin{array}{c}\text { Total } \\
\text { Glacierized } \\
\text { Area } \\
\left(\mathrm{km}^{2}\right)\end{array}$ & $\begin{array}{c}\text { Mean } \\
\text { Altitude } \\
\text { (mas1) }\end{array}$ \\
\hline 411 & Carson & 5 & $38 \quad 24.2$ & $119 \quad 37.9$ & 0.187 & 3206 \\
\hline 412 & W. Walker & 10 & $38 \quad 15.1$ & 11935.1 & 0.431 & 3284 \\
\hline 413 & E. Walker & 18 & $38 \quad 6.0$ & 11922.6 & 2.594 & 3337 \\
\hline 421 & Owens & 124 & $37 \quad 8.6$ & $118 \quad 35.2$ & 18.272 & 3690 \\
\hline 422 & Mono & 41 & 3751.7 & $119 \quad 15.5$ & 3.556 & 3527 \\
\hline 431 & Kings & 94 & 3655.2 & $118 \quad 31.8$ & 6.938 & 3638 \\
\hline 432 & Kaweah & 7 & $36 \quad 31.9$ & $118 \quad 33.8$ & 0.269 & 3404 \\
\hline 433 & Kern & 31 & 3634.0 & $118 \quad 27.5$ & 2.902 & 3736 \\
\hline 441 & Mokelumne & 1. & $\begin{array}{ll}38 & 39.1\end{array}$ & $120 \quad 1.8$ & 0.030 & 2812 \\
\hline 442 & Stanislaus & 9 & 3816.6 & 11940.6 & 0.366 & 3140 \\
\hline 443 & Tuolumne & 22 & 3755.9 & 11920.9 & 2.205 & 3505 \\
\hline 444 & Merced & 18 & 3743.6 & 11920.4 & 1.517 & 3459 \\
\hline 445 & San Joaquin & 112 & 3725.8 & $120 \quad 0.4$ & 10.243 & 3566 \\
\hline 456 & American & 5 & 3847.2 & 120 & 0.110 & 2933 \\
\hline
\end{tabular}


104 Inventory of Glaciers in the Sierra Nevada, California

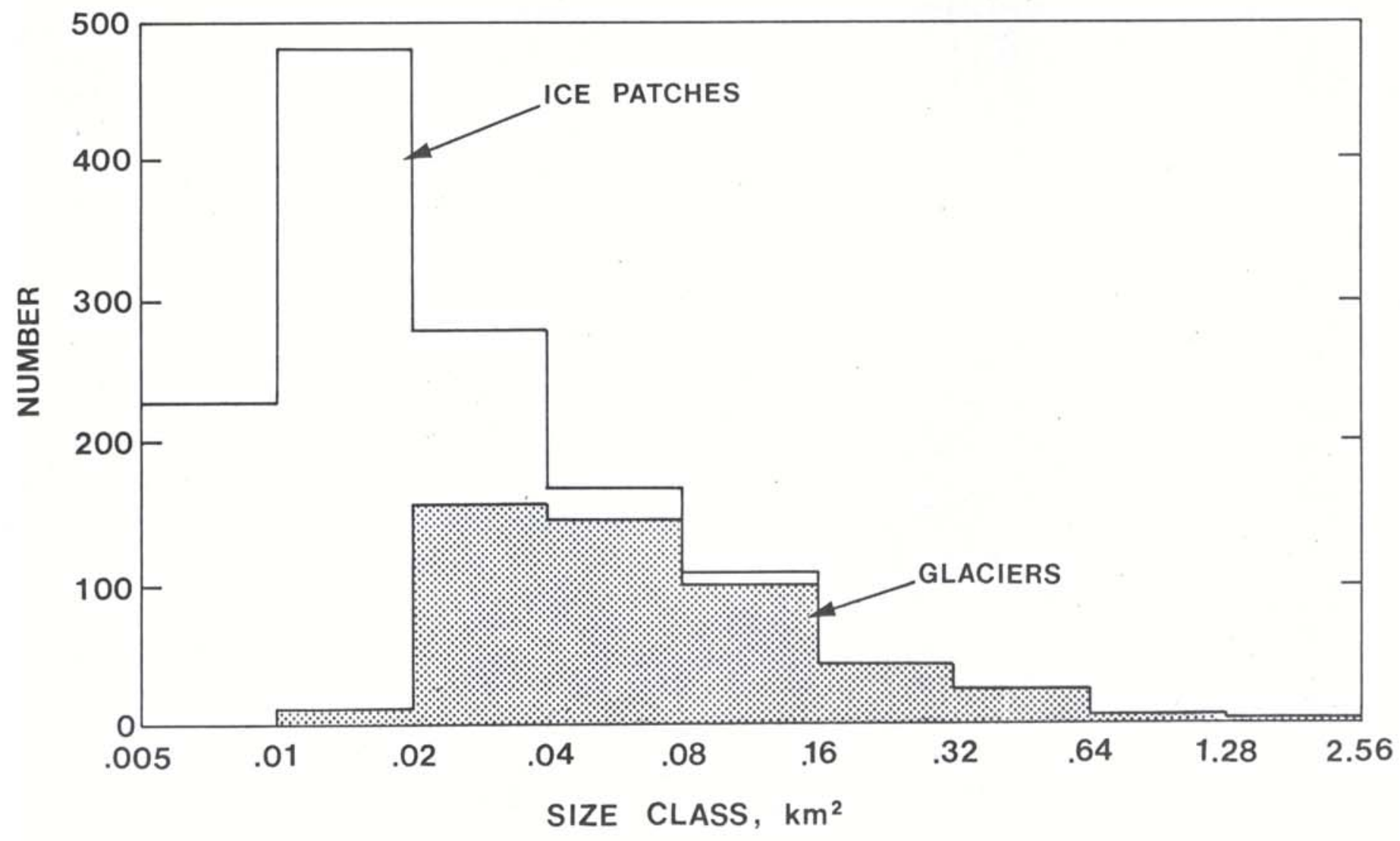

Figure 3. Graph showing number of glaciers and ice patches by size class distribution. 


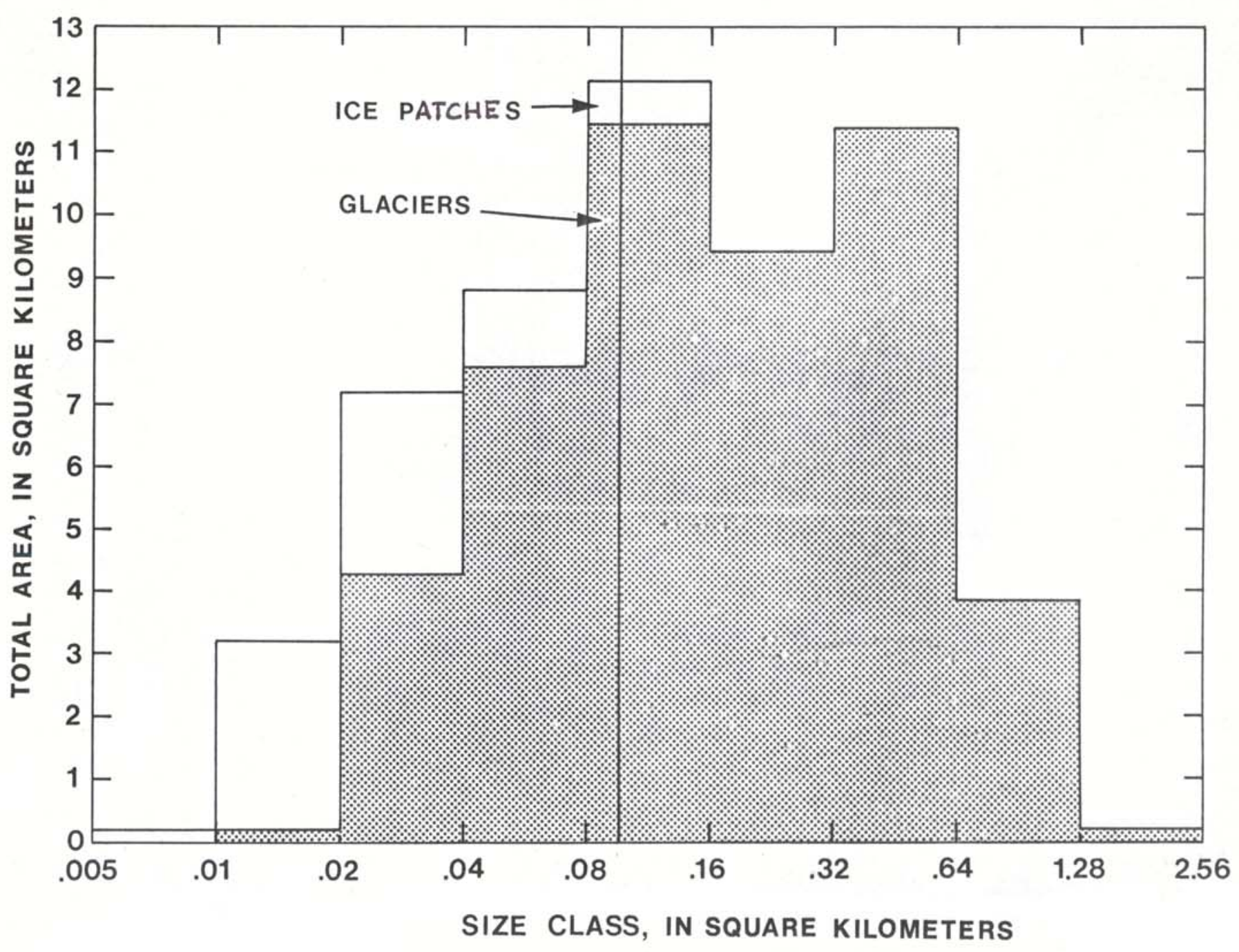

Figure 4. Graph showing glacier and ice patch area by size class distribution. 
Most of the glaciers in the Sierra Nevada exist because of their predominantly northerly orientation, high altitude, (fig. 5), and accumulation from direct snowfall and from drift snow brought by the southwest storm winds into the north-facing steep-walled cirques in which the glaciers are situated. These deep cirques also reduce ablation from direct solar radiation.

The glaciers occur from 3,000 to $4,000 \mathrm{~m}$ altitude, with the terminus of the lowest glacier at $2,769 \mathrm{~m}$ (fig. 6) and the head of the highest glacier at 4,267 $\mathrm{m}$. Although the mean altitude of the glaciers is $3,543 \mathrm{~m}$, by far the largest number terminate between 3,500 and $3,600 \mathrm{~m}$, demonstrating the relatively small vertical relief of most of these features. The largest total glacier area, $18 \mathrm{~km}^{2}$, occurs in the Owens basin, which is the highest basin in the Sierra Nevada, with a mean altitude of 3,690 m (fig. 7). 


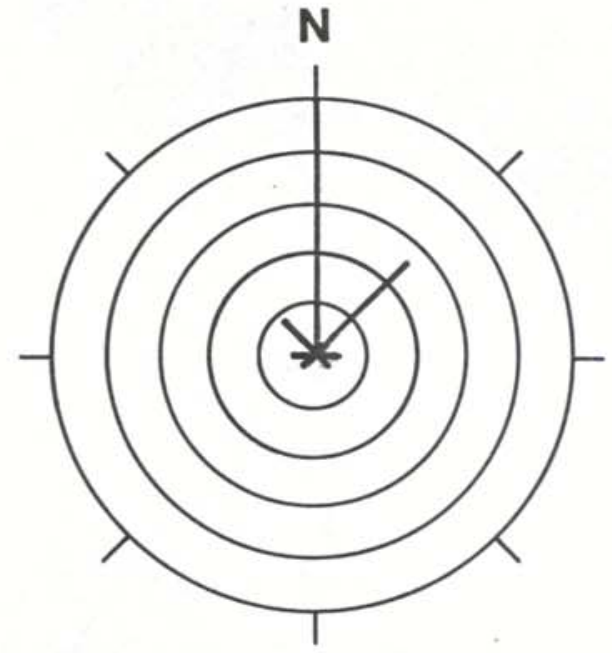

a.

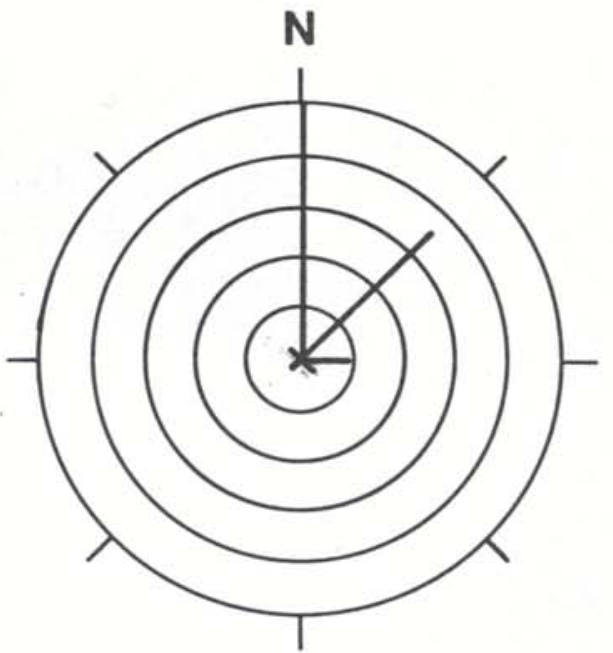

b.

Figure 5. Diagrams showing orientation of glaciers west of the crest and east of the crest. 


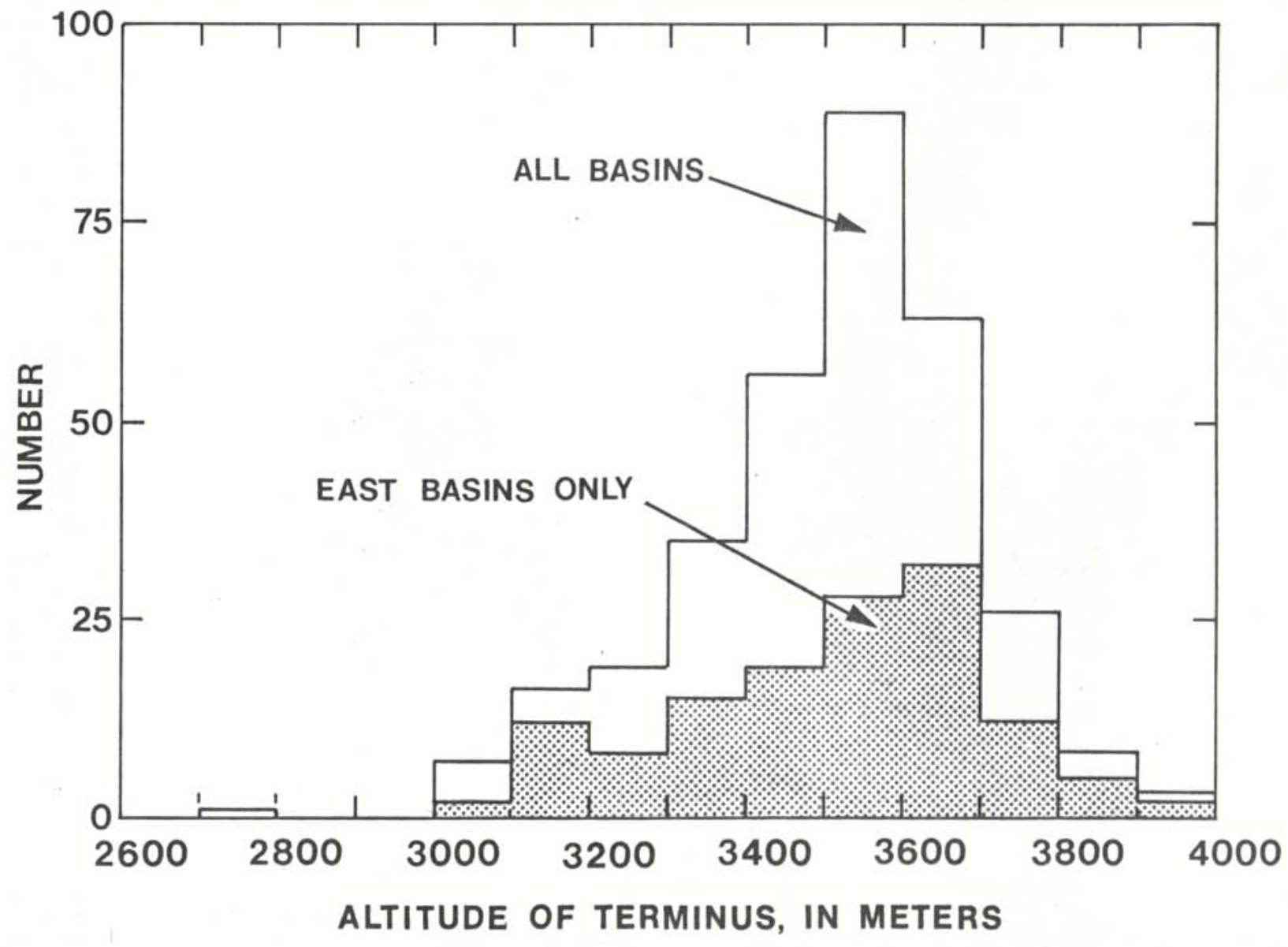

Figure 6. Graph of distribution of glaciers by terminus altitude. 


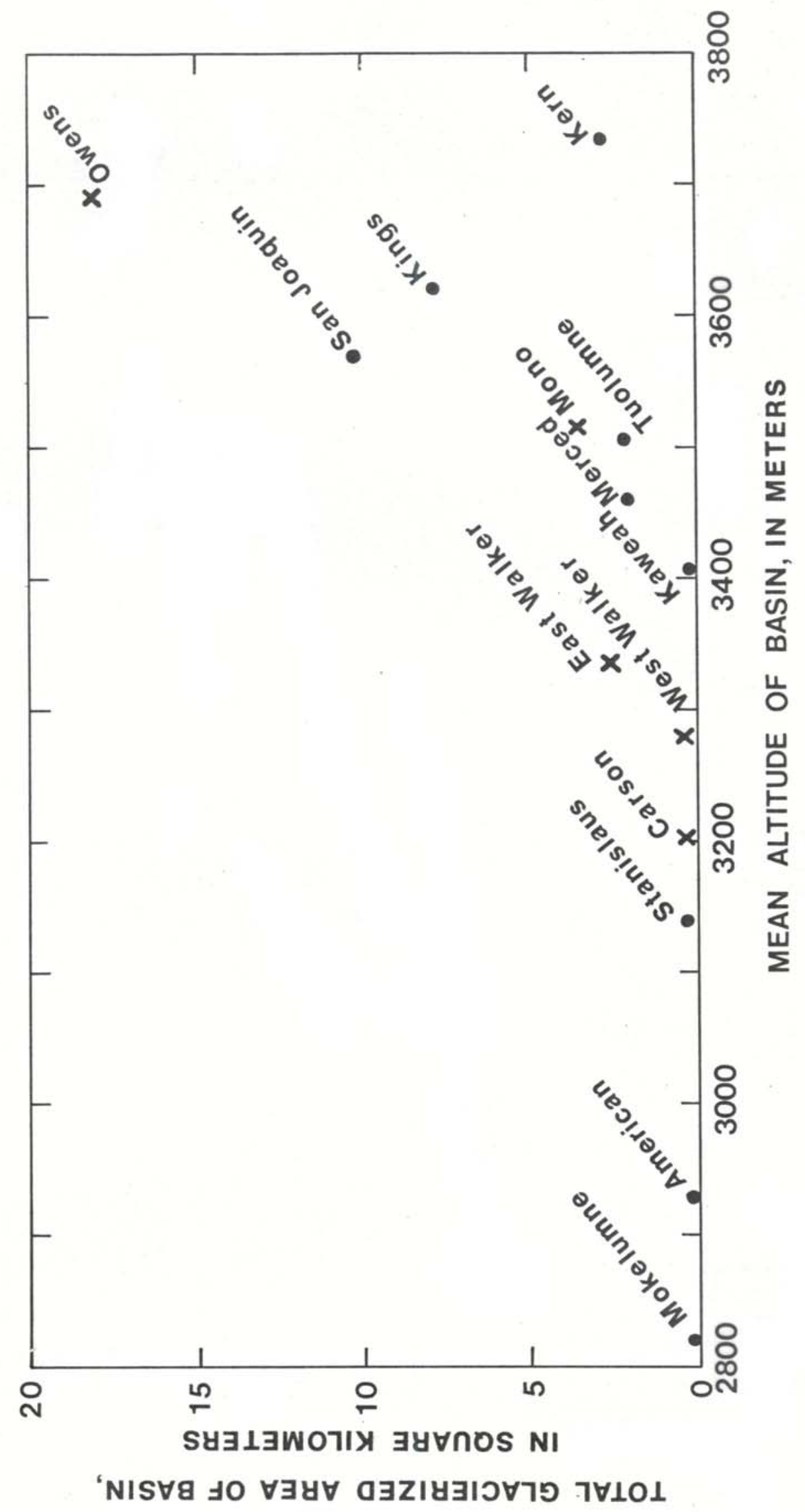


A plot of mean altitude of each glacierized basin versus its mean latitude (fig. 8) reflects the decrease in altitude of the Sierra Nevada in a northerly direction. This decrease in the mean altitude of the glaciers is to be expected from the cooling effects of increasing latitude there is also a much greater amount of precipitation in northern California (fig. 9) and this likewise should be taken into account. By a curious coincidence, only the highest parts of the range at any point rise above the annual snowline because the mean altitude of the range rises in a southerly direction slightly more rapidly than the snowline, the largest glaciers are all near the southern end. 


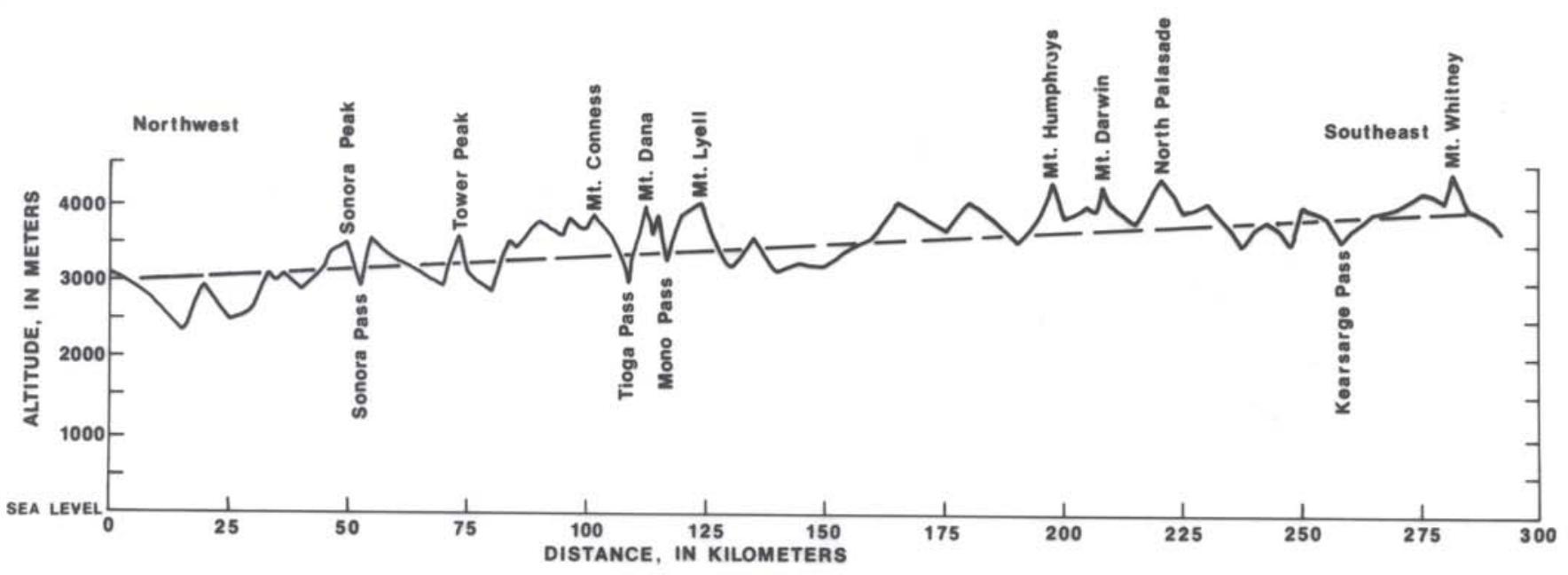

Figure 8. Northwest to southwest profile along the glaciated crest of the Sierra Nevada showing topography and gradient of mean glacier altitude. 


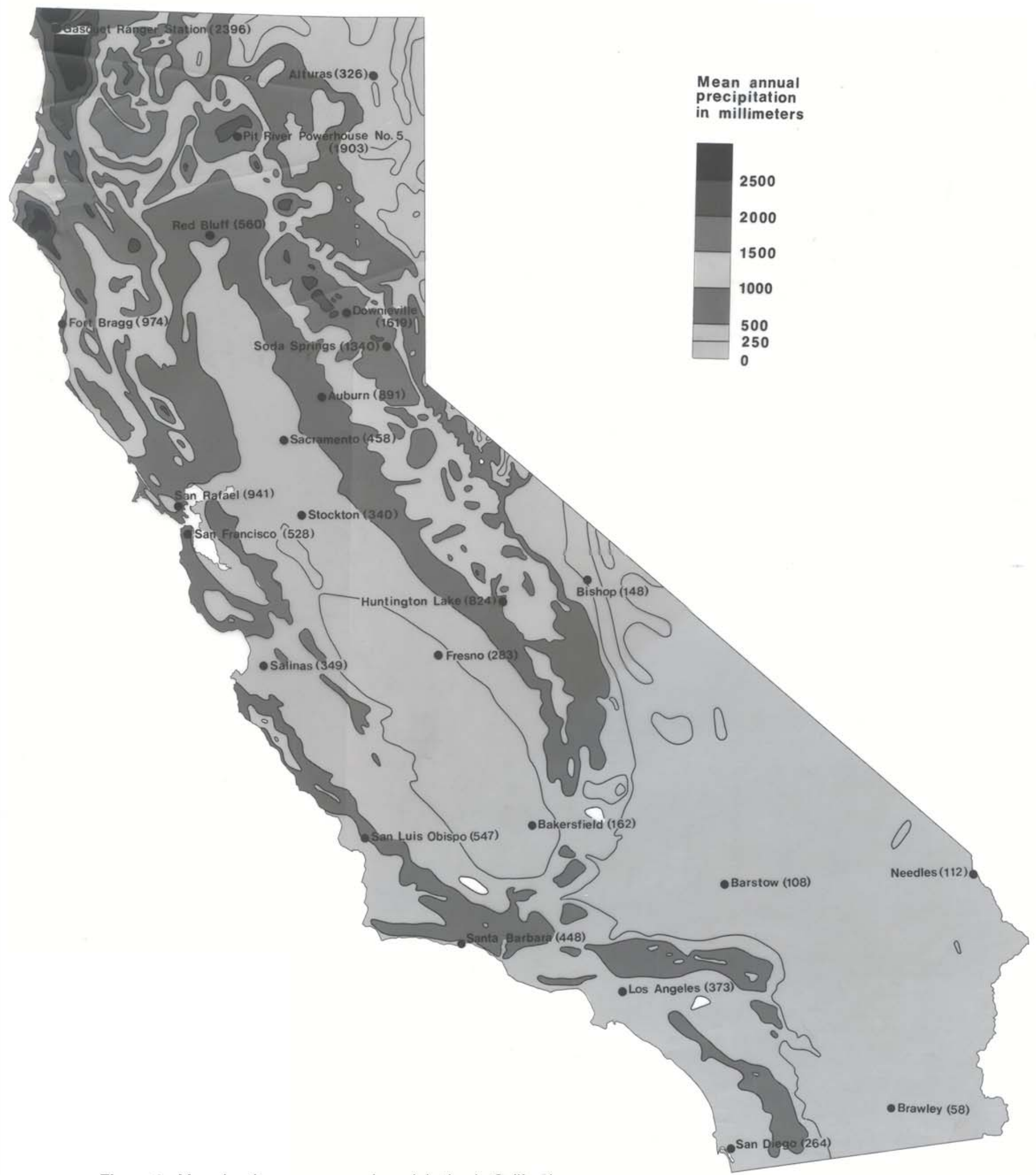

Figure 9. Map showing mean annual precipitation in California. 
HYDROLOGIC ASPECTS

\section{PRECIPITATION}

The Sierra Nevada is a great physical barrier to the eastward passage of moisture from the Pacific. Much moisture is precipitated out on the Coast ranges but a large amount remains to be deposited on the western slopes and crest of the Sierra Nevada, primarily in the form of snowfall. Winter is the season of prolonged general storms and thus of highest precipitation this is an important consideration in the continuing existence of the glaciers in the Sierra Nevada because this heavy precipitation falls as snow in the high basins. Precipitation is greatest in northern California and decreases dramatically southward (fig. 9) two-thirds of the average annual state total falls on the northern one-third the state (State of California, 1978, p. 3), and the southern part is one of the most arid regions in the United States. There is also a large spatial variation in evaporation in California. This of course affects the amount of water available for runoff. In the high Sierra, the annual evaporation amounts to less than $1,000 \mathrm{~mm}$, about half the amount of the local precipitation, while in the southeastern deserts the annual evaporation rises above 1,800 mm (State of California, 1978).

There is a large year-to-year variation in the amount of annual precipitation California receives (fig. 10). During years of drought there is a critical water shortage, and the wasting of glaciers and ice patches in the Sierra Nevada provides an additional source of water. 


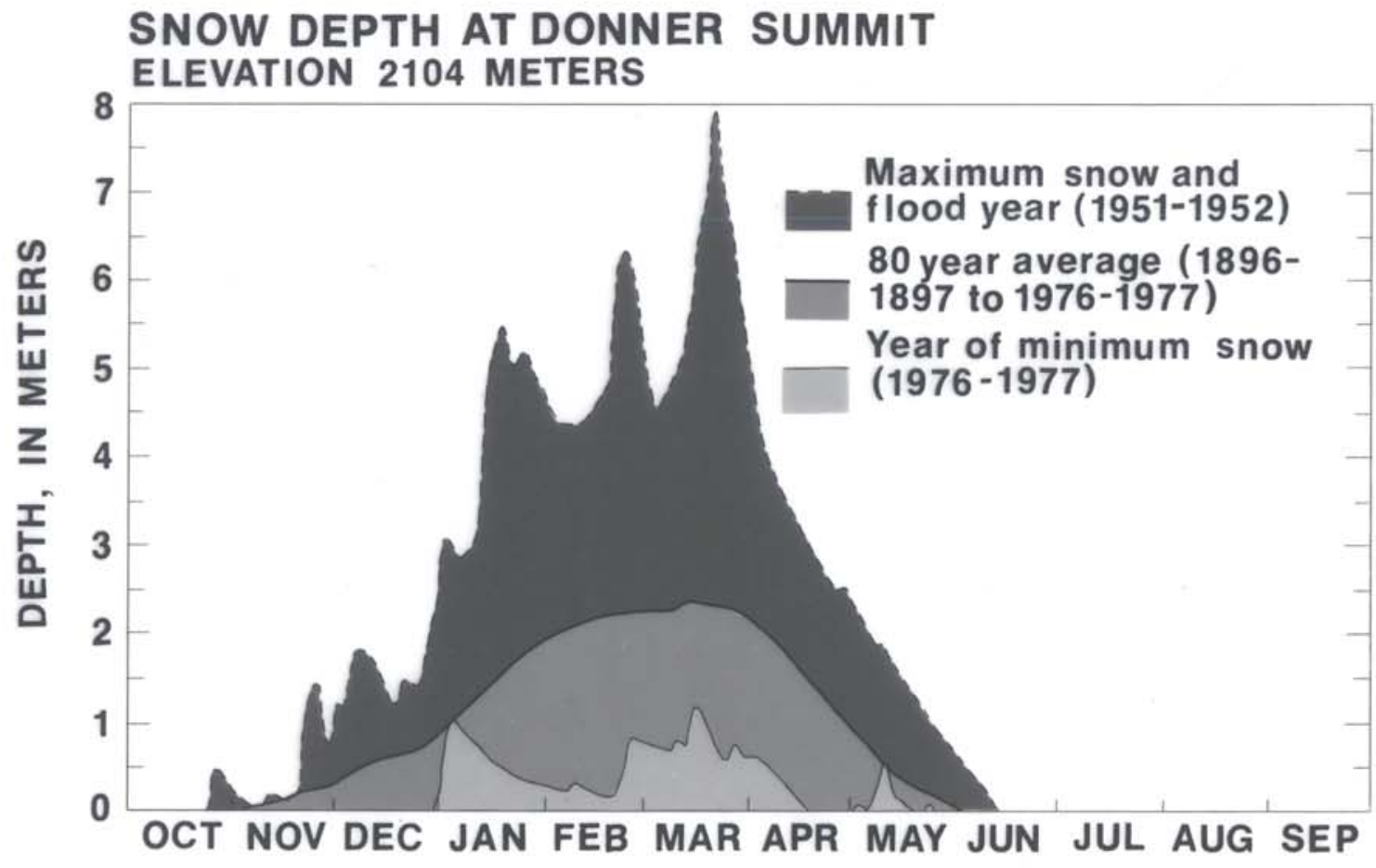

Figure 10. Graph illustrating snowfall variablility at Donner Summit. 


\section{RUNOFF}

Most of the snowfall in the Sierra Nevada remains until Spring, such that more than 60 percent of the mean annual runoff in most basins occurs after March 31 (State of California, 1978, p. 9). Snow at high altitudes melts later in the year than snow at low altitudes. The presence of glaciers plays an important role in delaying runoff. It has been shown (Krimmel and Tangborn, 1974; Fountain and Tangborn, 1985) that the presence of only a few glaciers (less than 5 percent of the total basin area) has a substantial effect on reducing the year-to-year variance of summer streamflow, as well as delaying the runoff. In years of low snow accumulation, the exposure of the low albedo glacier ice to radiation earlier than in years with normal or high accumulation will cause greater glacier melt and offset for the diminished runoff from snowmelt. The exposure and melting of this low albedo glacier ice late in the season is also a factor in the seasonal delay of runoff from glacierized basins. Another factor in this delay of the seasonal runoff is englacial water. The release each summer of this liquid water stored in the glacier during the previous fall, winter, and spring is nearly independent of any external climatic variations (Tangborn and others, 1972). 
The Kern, Kaweah, and Merced River watersheds (fig. 11) receive as much as 1,250-1,400 mm of precipitation. Runoff in these basins peaks during May and June and remains significant through July and August in part due partly to precipitation that occurs as snowfall into May at their headwaters and due to the presence of glaciers (fig. 12). Similar effects are observed in the Kings, San Joaquin, the East and West Walker and the Carson watersheds. Runoff in the Big Pine Creek in Owens basin on the eastern side of the mountain crest peaks in June and July (California Department of Water Resources, written commun., 1974). This later runoff is due to the higher proportion of glaciers per area, and the higher elevation and northeastern orientation of the glaciers. Nearly all the streams along this entire $8-\mathrm{km}$ divide head in glaciers. This is the most glacier-influenced runoff in the entire Sierra Nevada, with the glaciers serving as a small natural "water storage" facility for the Los Angeles aqueduct during the summer. Although precipitation increases northward to more than $1,800 \mathrm{~mm}$ in the Yuba and Feather River watersheds, there is a significant decrease in the altitude of the Sierra (fig. 8) such that the watersheds are not high enough to contain glaciers (fig. 2). This results in a massive early runoff during April or May, usually declining rapidly in June (fig. 12). 


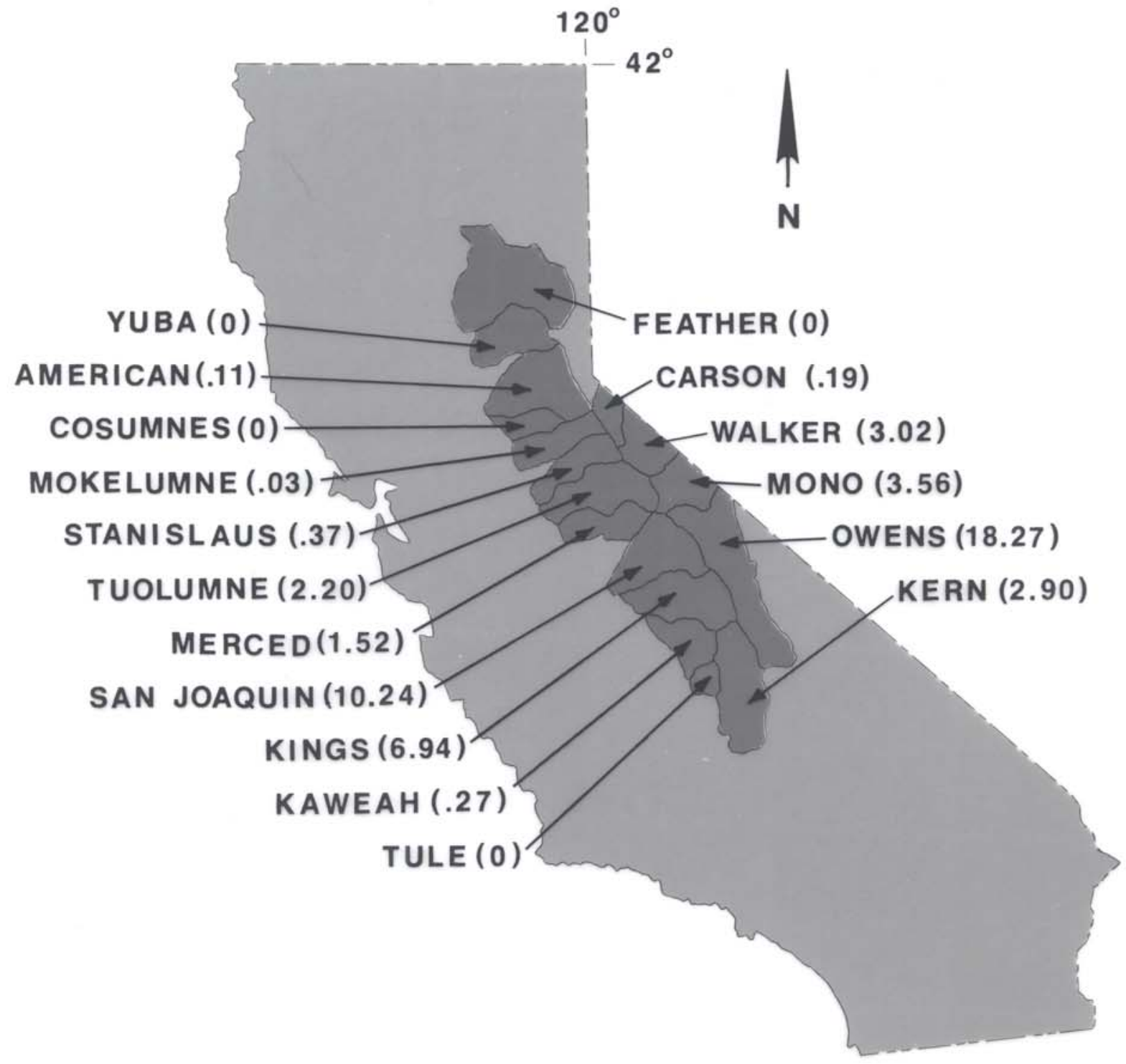

Figure 11. Map showing the location of the glacierized basins in the Sierra Nevada. 


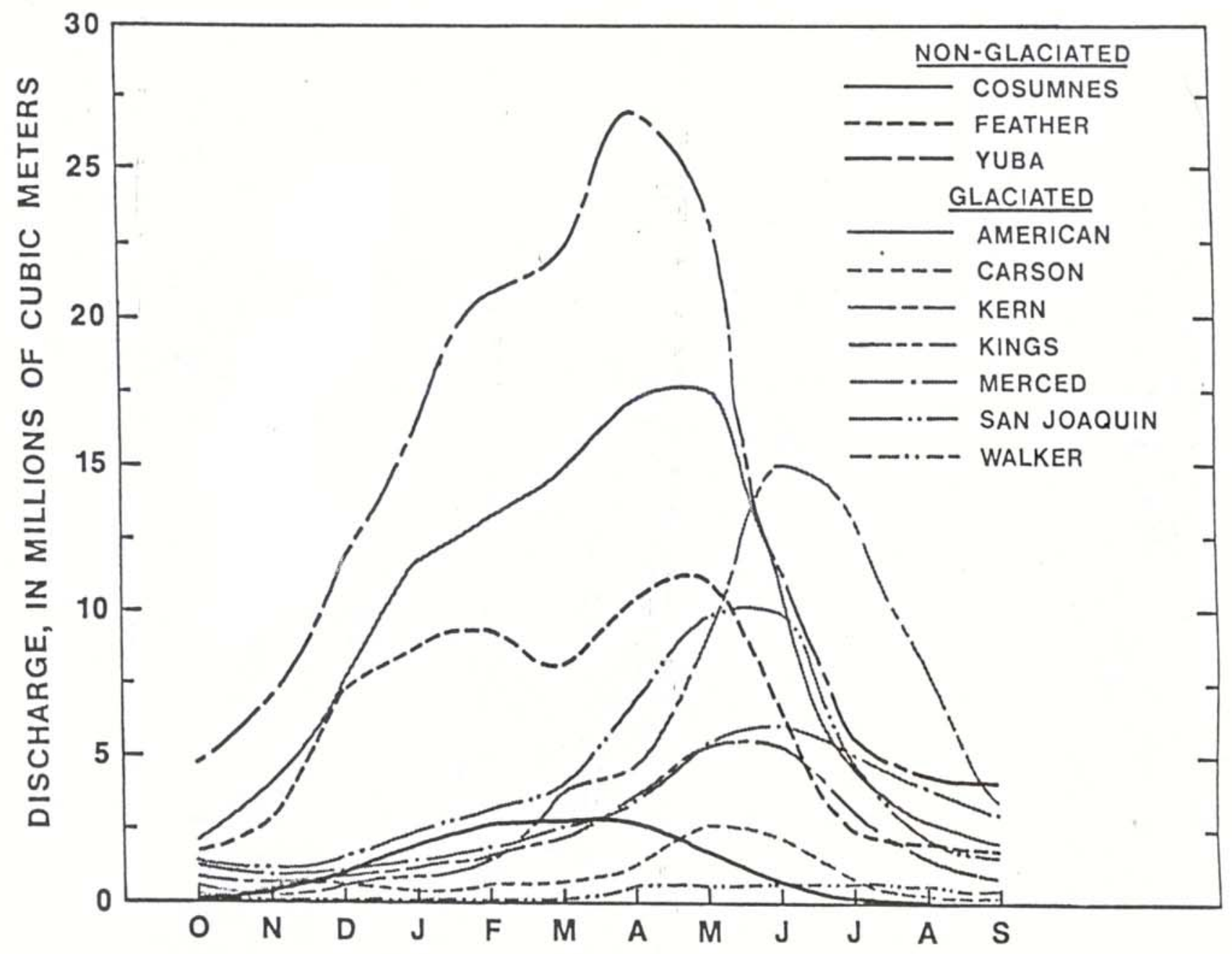

Figure 12. Graph showing comparison of times of maximum and minimum runoff in glacierized and nonglacierized basins. 
HYDROLOGIC SIGNIFICANCE

Besides having a large population, California is highly developed agriculturally and industrially. The resulting demands on water are high, with an overall average daily per capita water use in 1975 of 1,800 gallons, up from 600 gallons in 1900 (State of California, 1978, p. 1). Irrigated agriculture and electrical power generation are the two most significant users of water in California. Agriculture accounts for approximately 85 percent of the total yearly water consumption (State of California, 1978, p. 81). The entire flows of the Kern, Kaweah, and Kings Rivers, and the San Joaquin River south of Madera (figs. 1 and 2, pls. 3 and 4) are used for irrigation during dry years. Glaciers south of Kearsage Pass (p1. 3) help stabilize the flow on the South Fork Kings River during the dry summer months, as do the many sma11-tomedium-sized glaciers in the Kern River basin (U.S. Geological Survey, 1972). 
The significance of meltwater from even the small Sierra glaciers, ice-cored moraines, ice patches, and snowpack can be seen by comparing the September runoff (normally the month of minimum flow) versus the average annual (October through September) runoff for Cottonwood Creek, a nonglacierized basin and Big Pine Creek, a glacierized basin, both located in the Owens basin (fig. 13 and table 6). The September flow from the glacierized basin (Big Pine Creek) is more than four times that of the nonglacierized basin. If the difference in September runoff is caused by melting glaciers (neglecting lingering snow patches) then the glaciers must be melting about $0.5 \mathrm{~m}$ of ice averaged over the surface of each glacier. This large average melt rate agrees qualitatively with the observations of mass wastage of these glaciers described in the section on recent activity. These glaciers, small as they are, help stabilized streamflow, especially in severe drought years when the snowpack disappears early. 

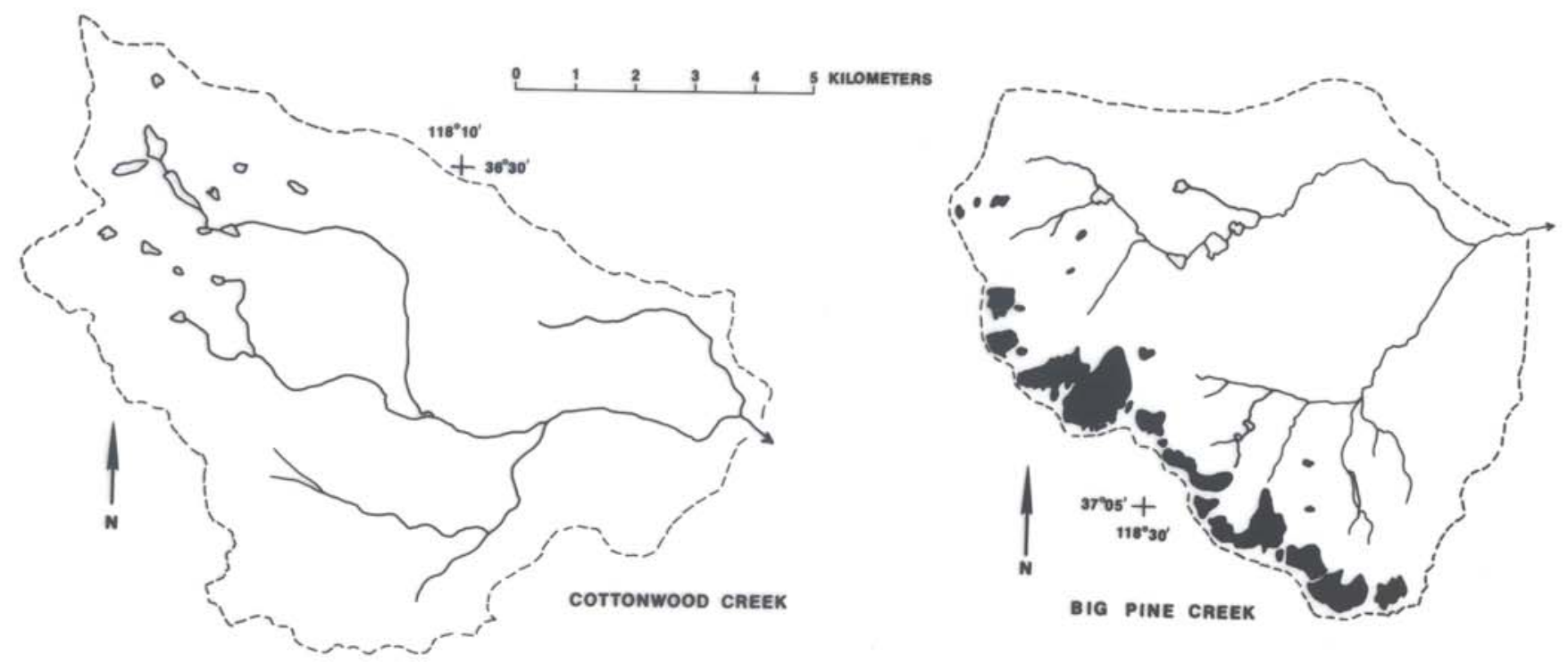

Figure 13. Depiction of the nonglaciated basin of Cottonwood Creek and the glaciated basin of Big Pine Creek. The dark polygons in the latter basin represent glacier extent. The open polygons represent lakes and ponds. 
Table 6.--Comparison of 34-year average precipitation ${ }^{1}$ and 40-year average runoff ${ }^{2}$ of a glacierized basin (Big pine Creek) and a non-glacierized basin

(Cottonwood Creek). August and september discharges show hydrologic significance of the glaciers. Both creeks are in Owens Basin.

\begin{tabular}{|c|c|c|}
\hline & Cottonwood Creek & $\begin{array}{l}\text { Big Pine Creek } \\
\text { near Big Pine }\end{array}$ \\
\hline $\begin{array}{l}\text { Watershed area } \\
\text { Glacier area } \\
\text { Annual runoff } \\
\text { Average altitude of basin crest } \\
\text { Altitude of precipitation gage } \\
\text { Average annual precipitation } \\
\text { Average annual discharge } \\
\text { Annual runoff } \\
\text { Average September precipitation } \\
\text { Average September discharge } \\
\text { September } \% \text { of total }\end{array}$ & $\begin{array}{c}104 \mathrm{~km}^{2} \\
0 \\
.16 \mathrm{~m} \\
3,795 \mathrm{~m} \\
3,233 \mathrm{~m} \\
434 \mathrm{~mm} \\
19.58 \times 10^{6} \mathrm{~m}^{3} \\
.19 \mathrm{~m} \\
21 \mathrm{~mm} \\
.59 \times 10^{6} \mathrm{~m}^{3} \\
8.3 \%\end{array}$ & $\begin{array}{c}101 \mathrm{~km}^{2} \\
645 \mathrm{~km}^{2} \\
.37 \mathrm{~m} \\
4,188 \mathrm{~m} \\
2,501 \mathrm{~m} \\
422 \mathrm{~mm} \\
37.63 \times 10^{6} \mathrm{~m}^{3} \\
.37 \mathrm{~m} \\
21 \mathrm{~mm} \\
2.71 \times 10^{6} \mathrm{~m}^{3} \\
22 \%\end{array}$ \\
\hline
\end{tabular}

1 Precipitation data from City of Los Angeles Department of Water and Power, Division of Hydrography.

2 Discharge data from R. Wells, Los Angeles Department of Water and Power, personal communication. 


\section{REFERENCES}

Adams, A. 1932, Photograph of Mt. Lyel1 and Mt. Dana: Sierra Club Bulletin, v. 17, p. 22 .

Birkeland, P. W., Crande11, D., and Richmond, G., 1971, Status of correlation of Quaternary stratigraphic units in the western conterminous United States: Quaternary Research, v. 1, no. 2, p. 208-227.

Birman, J. H., 1964, Glacial geology across the crest of the Sierra Nevada: Geological Society of America Special Paper 75, 80 p.

Blackwelder, E., 1931, Pleistocene glaciation in the Sierra Nevada and Basin Ranges: Geological Society of America Bulletin, v. 42, p: 865-922. Burke, R.M., and Birkeland, P.W., 1983, Holocene glaciation in the mountain ranges of the western United States, in Wright, H.E., Jr., ed., Late-Quaternary environments of the United States: Minneapolis, MN, University of Minnesota Press, p. 3-11.

California State Department of Water Resources, 1975, Water conditions in California: Bulletin 120-75, Report 4, May 1, p. 8-9.

Dean, W. W., 1974, McClure Glacier, California--a contribution to the International Hydrological Decade: Proc. 42nd Annual Meeting, Western Snow Conference, Anchorage, AK, April 16-20, 1974.

Denton, G., and Porter, S., 1967, Chronology of Neoglaciation in the North American Cordillera: American Journal of Science, v. 265, p. 177-210. Farquhar, F. P., 1920, Photograph of Lyell Glacier: Sierra Club Bulletin, v. 11, p1. 23 .

Fountain, A.G., and Tangborn, W.V., 1985, The effect of glaciers on streamflow variations: Water Resources Research, v. 21, no. 4, p.579-586. 
Gilbert, G. K., 1904, Variations of Sierra glaciers: Sierra Club Bulletin, v. 5, p. $20-25$.

Harrison, A. E., 1950, Glaciers then and now: Sierra Club Bulletin, v. 35, no. 6, p. $113-116$. 1951, Are our glaciers advancing?: Sierra Club Bulletin, v. 36, no. 5, p. $78-81$. 1956, Glacial activity in the Western United States: Journal of Glaciology, v. 2 , no. 19, p. 666-683.

Heald, W. F., 1947, Palisade Glacier survey, Sierra Nevada: American Alpine Journal, v. 6 , no. 3, p. 332-339.

Hil1, M. R., 1975a, Geology of the Sierra Nevada: Berkeley, University of California Press, p. 124-161. 1975b, Living glaciers of California--a picture story, in California Geology: California Division of Mines and Geology, v. 28, no. 8, p. $171-177$.

Kehrlein, 0., 1950, Death comes to a glacier: Pacific Discovery, v. 3, no. 3, p. $8-18$.

Krimme1, R. M., Tangborn, W. V., and Meier, M. F., 1973, Water flow through a temperate glacier: Proceedings of the International Symposia on the Role of Snow and Ice in Hydrology, Banff, 1972.

Krimme1, R. M., and Tangborn, W. V., 1974, South Cascade Glacier: the moderating effect of glaciers on runoff: Proceedings Western Snow Conference, Anchorage, Alaska, April 1974.

Lawson, A. C., 1904, The geomorphology of the upper Kern basin: California University Department of Geology Bulletin, v. 3, no. 15, p. 291-376. 
Matthes, F. E., 1930, Geologic history of the Yosemite Valley: U.S. Geological Survey Professional Paper 160, 137 p. 1940, Report of the Committee on Glaciers, 1930-40, in American Geophysical Union Trans. of 1940, Part II, 21st Annual Meeting, April 24-27, 1940, Washington, D. C., The National Academy of Science, p. 396-406. 1948, Moraines with ice cores in the Sierra Nevada: Sierra Club Bulletin, v. 33 , no. 3, p. $87-96$.

Meier, M. F., and Post, A., 1962, Recent variations in mass net budgets of glaciers in western North America: International Union of Geodesy and Geophysics, International Association of Scientific Hydrology, Obergurg1 Symposium, Pub. 58, p. 63-77.

Muir, J., 1871, The mountains of California: New York, Doubleday and Co., Inc., and the American Museum of Natural History.

National Park Service, 1976, Report of glacier studies in Yosemite National Park, 1975: report prepared by Warren White, Yosemite National Park, California, $20 \mathrm{p}$.

Post, A., Richardson, D., Tangborn, W., and Rosselot, F., 1971, Inventory of glaciers in the North Cascades, Washington: U.S. Geological Survey Professional Paper 705-A, 26 p.

Russe11, I. C., 1885, Existing glaciers of the United States: U.S. Geological Survey 5th Annual Report, 1883-84, p. 303-355. 1889, Quaternary history of Mono Valley, California: U.S. Geological Survey 8th Annual Report 1886-87, p. 261-394. 1897, Glaciers of North America: Boston, Ginn and Co., 210 p. 
Sharp, R. P. and Birman, J. H., 1963, Additions to classical sequence of Pleistocene glaciations, Sierra Nevada, California: Geological Society of America Bulletin, v. 74, no. 8, p. 1079-1086.

State of California, 1978, The California Water Atlas: Governor's Office of Planning and Research in cooperation with the California Department of Water Resources, $118 \mathrm{p}$.

Tangborn, W. V., Krimmel, R. M., and Meier, M. F., 1972, A comparison of glacier mass balance by geologic, hydrologic, and mapping methods, South Cascade Glacier, Washington: Proceedings IUGG, Moscow General Assembly, 1971. UNESCO/IASH, 1970, Combined heat, ice and water balances at selected glacier basins, a guide for compilation and assemblage of data for glacier mass balance measurements: UNESCO/IASH Tech. Papers in Hydrology, no.5, $20 \mathrm{p}$. U.S. Geological Survey, 1972, Runoff characteristics of California streams: U.S. Geological Survey Water Supply Paper 2009-A, p. A-26.

Wahrhaftig, C., and Birman, J. H., 1965, The Quaternary of the Pacific mountain system in California, in Wright, H. E., Jr., and Frey, D. G., eds., The Quaternary of the United States: Princeton, N. J., Princeton University Press, p. 299-340. 1966, Sierra Nevada Province in Geology of northern California: California Division of Mines and Geology Bulletin, 190, p. 105-172. 
APPENDIX 1.--Description of items in tables 1 and 2.

4111

0.1 Snow in niche.

1 Two ice-filled chutes at head of Silver King Creek.

2 Glacier at head of Silver King Creek.

2.1 Snow patches under headwa11.

2.2 Snow patch or patches in cirque at head of Fly Valley.

3 Small glacierette(?) in cirque at head of Fly Valley.

4 Small glacierette(?) in cirque at head of Fly Valley.

4.1 Ice pocket(?) with snow-filled chute at head of Bull Canyon.

4.2 Snow in saddle above Whitecliff Lake.

4112

0.1 Snow patch in cirque on NW side of Whitecliff Peak.

0.2 Snow in col.

0.3 Snow in chute at the head of a cirque.

1 Tiny glacierette NNE side of Sonora Peak cirque.

1.1 Snow under headwall in the western part of Sonora Peak cirque.

1.2 Ice pocket in niche.

4121

0.1 Snow under small headwall.

1 Glacierette on Ehinbeck Peak. Bergschrund, glacial ice, small. crevasses. Sinuous moraine front.

1.1 Snowdrift.

1.2 Snowfield, Nivation cirque forming?

1.3 Cluster of snow patches, some long, filling clefts or joints.

1.4 Cluster of long, slender snow fingers. Snow-filled joints?

1.5 Ice pocket in cleft. Two shades of snow or ice, small bergschrund. 
APPENDIX 1.--Description of items in tables 1 and 2--Continued

2 Tower Peak glacier in granite cirque under steep, shady headwa11. Small bergschrund, several shades of snow to ice.

3 Cliff accumulation under $W$ headwall of Tower Peak.

3.1 Snowdrift.

3.2 Snow or ice in cleft.

4 Ice pocket or tiny glacierette in cleft, ice-filled chutes. Few cracks in upper area, trace of bergschrund.

4.1 Snow accumulation. Drift?

4.2 Snowdrift.

4.3 Snow in clefts.

5 Ice pocket lies under steep, shady headwa11. Moraine, but with no sharp-crested front.

5.1 Snowdrifts in shelves.

5.2 Snow in chutes and clefts.

6 Probably snowfield in high, level saddle extending down into small shallow cirque.

6.1 Snow accumulation.

6.2 Snow accumulation. Considerable talus and/or moraine below.

6.3 Probably buried ice and interstitial ice and rock. Wide bergschrund-1ike separation. Moraine is rounded.

6.4 Snow accumulation in bottom of a draw.

6.5 Cluster of snow patches above and below Latopie Lake.

7 Small glacierette in cirque. Light crack in upper area. Sharp-crested moraine, steep front.

7.1 Snow or ice pocket. 
APPENDIX 1.--Description of items in tables 1 and 2--Continued

4122

0.1 Snow under sma11, steep headwa11.

0.2 A possibly permanent snow or ice body in a narrow cirque.

1 Glacierette? Moraine front.

1.1 Snow in chute.

2 Glacierette? Moraine front.

3 Headwall accumulation on $\mathrm{N}$ Side. Several small moraine fronts.

3.1 Snow or ice pockets under chutes. Small moraine fronts.

4131

0.1 Snow-ice pocket in niche under cliff.

1 Glacierette(?) under shady cliff. Short, lumpy, moraine-like accumulation.

2 Ice pocket in shallow cirque or cliff. Lumpy moraine.

3 Glacier with small bergschrund, dark, fine-textured rock mantle on lower half. Sharp crest, steep front.

3.1 Snow in niche at head of shallow, narrow cirque. Appears deep.

3.2 Tiny glacierette? Low, arcuate moraine.

3.3 Cliff ice accumulation appears deep. Suggestion of small arcuate moraine.

4 Glacierette above Par Value Lake. Trace of bergschrund, several shades of snow. Morainal loops, older deflated moraine lies below.

4132

1

1.1 Snowfield perched in high saddle. 
APPENDIX 1.--Description of items in tables 1 and 2--Continued

1.2 Ice pocket accumulation under ice-filled chute. Tongue-like moraine extension.

2 Fairly large glacier. Bergschrund, snow-filled chutes, pedestal rocks, rock-mantled lower part. Looping ridges, low, steep front.

3 Large glacier. Bergschrund, snow-filled chutes, crevasses, banded ice. Rock mantles part of glacier. Sharp-crested moraine, older deflated moraine below.

4 Tiny glacierette in headwall cleft. Few checks in upper area. Moraine spills talus to canyon floor.

4.1 Snow-ice pockets in niche under cliff. Appear deep.

5 Small glacierette lies on $\mathrm{N}$ side of saddle in cleft. Lumpy moraine.

6 Dying glacier. Bergschrund, cracks, new moraine forming half way up. Old remnant terminates at pond which lies in back of old moraine loop (trees).

7 Large glacier on $\mathrm{N}$ side of Matterhorn Peak. Bergschrund, ice-filled chute, pedestal rocks, some rock mantle. Sharp-crested moraine.

8 Fairly large glacier, two headwall sources. Bergschrund, cracks, pedestal rocks, mantle. Sharp-crested but low moraine. Three talus spillages.

8.1 Cliff ice pocket. Cracks, dirty ice.

8.2 Cliff ice pocket. Cracks, dirty ice.

9 Glacier above Avalanche Lake. Bergschrund, bare ice with pedestal rocks, rock mantle. Moraine crest.

10 Cliff ice accumulation. Associated with glacier to W. 
APPENDIX 1.--Description of items in tables 1 and 2--Continued

11 Small glacier(?) in jointed granitic headwall. No bergschrund but several shades of snow. Much rock mantle. Moraine.

11.1 Cliff ice pockets just west of glacier 11 .

12 Dirty remnant cliff glacier. Trace of bergschrund, much rock mantle. Two low moraine snouts, pond under western snout.

12.2 Snow accumulation in niche. Deep appearance.

12.3 Snow accumulation under shady cliff. Has cracks, appears deep.

12.4 Cliff snow accumulation.

12.5 Deep snow pocket filling cleft.

12.6 Snow filling eroded granitic joint.

13 Glacierette. Trace of bergschrund, cracks cut ice-filled chute in small cleft-like cirque on $N$ side of Crown Point. Rock mantle on ice, pedestal rocks(?). Moraine crest front.

13.1 Ice pocket in shady niche or chute.

13.2 Snow pocket in cleft. Appears deep, has cracks.

13.3 Shallow snow patch on slope.

4133

1 Humewill Peak glacier. Long, thin moraine.

1.1 Possible small rock glacier.

1.2 Snow or ice in chute above cirque.

4211

0.1 Mt. Langley snow- or ice-filled chutes.

1 Mt. Corcoran's SE headwall glacierette. Small front at angle of repose. Deflated older moraine below with discharge from terminus. 
APPENDIX 1,--Description of items in tables 1 and 2--Continued

2 Mt. Corcoran's NE rock glacier. Some permanent ice in headwall. Arcuate, stepped loops on surface for $900 \mathrm{~m}$ below the headwall. Ice core is thinning out in back of lowest front, discharge from base.

3 Mt. McAdie remnant glacier, still inflated, pedestal rocks on dirty ice. Bergschrund about $300 \mathrm{~m}$ across, looping rock-mantled ridges. Front terminates in Consultation Lake.

4 Small cliff glacierette, E side of Whitney Pass. Dirty surface, moraine front.

5 Trail Crest rock glacier. About six stepped, looping ridges, front. Some bare ice in upper areas. Inflated look.

6 Tiny cliff glacierette with steep, dirty headwall ice. Crack across top of ice. Inflated body with double front. Tiny pond on surface. Tiny ponds at base of front.

7 Dying glacierette and ice-filled chutes lie below steep headwall. Cracks in upper ice. Hummocky, gently-sloping, rock-mantled lower areas, still inflated with ice, but low front.

7.1 Ice pocket.

8 Solid, well-formed small glacier lies in shady niche or narrow cirque. Ice-filled chute, bergschrund, rock mantle. Discharge from crest of high moraine front. Front spills to basin floor at pond. 
APPENDIX 1.--Description of items in tables 1 and 2--Continued

8.1 Probably snow accumulation.

9 Small dying cliff glacier lies under steep, shady headwall just $W$ of Tunnabora Peak. Ice in chutes, pedestal rocks, bergschrund. Inflated look with looping ridges. Discharge from base of Eront. Partial snow-ring ${ }^{1}$ lies in moat.

1 Snow-ring: Term used by Raub for the "ring of snow" in the moat area on each side of the inflated snout and around the base of the moraine front of many Sierra Nevada Glaciers.

\subsection{Tce pocket.}

10 Ice pocket with dirty ice lies under steep, shady headwall. Moraine deflated in lower areas. Discharge from base of lower areas. Small glacier probably occupied cixque until recently.

11 Remnant headwall glacier with rock glacier extension. Headwall has dirty ice with cracks in bergschrund area. Many looping, low morainal ridges. Appears to be thinning out--either remnant ice core or much interstitial ice, still has steep front. Discharge below base rubble.

11.1 Snow patch.

11.2 Snow accumulation. 
APPENDIX 1.--Description of items in tables 1 and 2--Continued

12 Remnant glacier or active rock glacier at head of $\mathrm{N}$ Fork Bairs Creek. Headwall ice (ice-filled chutes?). Thick, inflated rock-glacier extension. Steep front. Good discharge shows from older moraine below.

12.1 Icy snow accumulation.

12.2 Snow accumulation.

13 Cliff ice accumulation in shady niche, NW side of Mt. Williamson. Sharp moraine front.

14 Compound, remnant glacier. Triple body, steep front. Each lobe has looping ridges. Headwall ice has few cracks, deep, steep chutes, some with ice. Occupies niches of large cirque. Tiny ponds below fronts to SE. Sharp-crested moraine terminates in lake.

14.1 Two lesser ice parts to this feature.

14.2

14.3 Snow patches.

0.1 Cluster of snow patches.

0.2 Snow patch.

1 Remnant glacier on SE side of University Peak. Has arcuate moraine whose front overrides side of the inflated, rock-mantled main body. Terminus of main body narrows below to a snout.

2 Small glacier with rock out-crops through snow in upper areas. Inflated, rock-mantled. Front spills talus far below.

2.1 Snow patches under headwal1.

2.2 Snow or ice pocket.

2.3 Snow patches lie in scattered niches. 
APPENDIX 1.--Description of items in tables 1 and 2--Continued

2.4 Snow in perched niche.

2.5 Small rock glacier? Front snow patch on western headwa11.

2.6 Small ice pocket in headwall niche.

3 Active rock glaciers or rock-loaded glacierettes near Parker Lakes. Several inflated snouts and steep fronts. Shady chutes may contain ice or snow. 0lder deflated moraines below present fronts.

3.1 Ice under headwall, possible glacierette. Lobate extension, front, several looping ridges.

3.2 Rock glacier? Snow patches at head.

3.3 Front parallel with side wall. Rock glacier or continuous talus front? Some associated snow patches.

4 Ice pocket in shallow niche $\mathrm{N}$ side of Black Mt. Tiny pond at base.

4.1 Snow or ice patch just north of glacier 4. More snow patches at head of cirque.

4.2 Snow patches under low headwall.

4.3 Possible rock glacier. Many folds and loops. Snow patches and ice in chute above.

4.4 Snow or ice pocket in shallow tiny cirque. Tiny moraine?

5 Small glacier. Bergschrund cuts ice in shady cleft in shady cirque. Cracks in ice. Steep front. Pond sits on rock-mantled, lobate, inflated body.

6 Narrow, dying, bare ice glacierette with rock glacier extension at head of Armstrong Canyon. Headwall ice. Still-inflated body. Sharp crest, front. Older deflated ground morainal ridges below the present steep front. 
APPENDIX 1.--Description of items in tables 1 and 2--Continued

6.1 Possible tiny rock glaciers. Low loops, fronts.

6.2 Rock glacier? Sharp-crested front but a few dwarf trees are growing upon it.

7 Perched ice pocket in $\mathrm{N}$ side of peak. Tiny, arcuate, low moraine spills talus onto inflated rock glacier below. Narrow front spills into a narrow pond.

7.1 Snow or ice pocket.

4213

1 Glacierette(?) just $E$ of main Cardinal Glacier. Two ice-filled chutes, small bergschrund. Rock-mantle front. Complex moraine system below. Grades into rock glacier.

2 Large bergschrund cuts ice-filled chutes. Crevasses, root pendant above, dark rock-mantled, flow-looping, ice-core inflated in lower areas. Collapse wells. Steep front, complex moraine system.

3 Cliff glacierette under steep headwa11 just to NW of Cardinal Glacier. Crevasses, sharp-crested moraine.

4 Long rock glacier.

4.1 Ice pocket with many crevasses.

5 Small cliff glacierette lies under dark, fluted, headwall of Split Mt. Small bergschrund, crevasses. Discharge cuts slot in crest of moraine. Long talus descends to Red Lake. Banded surface.

6 Small glacierette to NNW of Red Lake. Small crevasses, two shades of snow. Tongue-like moraine with sharp front. 0lder, deflated moraine below. 
APPENDIX 1.--Description of items in tables 1 and 2--Continued

7 Glacier with bergschrund which cuts ice-filled chutes. Crevasses, fine-textured, looping, rock mantle ridges. Low but steep front. Ice core or rock glacier extension.

7.1 Snowy area, part of glacier 7 .

8 Crevassed, rock-mantled ice. Unusual snout is bent to $\mathrm{E}$ as the glacier just to $W$ deflects it. Narrow snout widens to a lobate front which spills into Tinemaha Lake.

9 Dying glacier, now a dirty, ice-filled chute. Trace of bergschrund cuts rock-mantled ice. The inflated lobate terminus deflects the snout to the SE. Steep front.

10 Mostly rock glacier. Upper part is dirty, ice-filled chutes. Trace of a bergshcrund. Looping, rock-mantled, still-inflated body. Low but steep front suggests mostly active rock glacier.

11 Dying glacier grading into active rock glacier. Dirty ice in chutes and upper area. Looping, folded ridges. Deflating look towards the snout.

11.1 Avalanche accumulations.

11.2 Mostly rock glacier, but some dirty rock-covered ice in the upper area.

12 Glacier with at least three shades of snow to ice. Bergschrund cuts ice-filled rocks. Rock-mantle over lower part. Snow ring lies in the moats. Steep front.

12.1 Snow ring filling the moat area.

13 Beautiful glacier. Bergschrund, crevasses, pedestal ice. Sinuous, sharp-crested moraine, steep front. Discharge from base.

13.1 Ice pockets, remnants of past glacierette? 
APPENDIX 1.--Description of items in tables 1 and 2--Continued

14 Small glacierette. Moraine front and small associated ice pockets. 4214

1 Small bergschrund. Collapse well pond on rock-mantled surface. Many looping surface ridges. Snow ring lies in the moat. Banded ice. Probable ice core to the terminus crest.

2 Main Middle Palisade Glacier. Fluted headwa11, large bergschrund, banded glacial ice, pedestal rocks, cravasses, ice-filled chutes. Sinuous, multi-ridged end moraine. Two fronts. Discharge from crest of $E$ snout and from base of $W$ front.

3 Western part of Middle Palisade Glacier. Steep, fluted headwall, large bergschrund, crevasses, banded ice and many pedestal rocks. Sharp-crested, sinuous end moraine. Talus spills to lake below, discharge from base. Separated from other glacier by narrow moraine. There is an ice pocket perched in shallow cleft above.

3.1 Perched permanent snow.

3.2 Ice patch with possible crevasses; arcuate moraine.

3.3 Small snow accumulation under cliff.

3.4 Avalanche snow. Lower patch is crevassed.

4 Huge, ragged bergschrund cuts ice-filled chutes. Crevasses, banded ice. Perched wing of ice extends under headwall to $\mathrm{W}$. Long snout descends below average elevation. Square-fronted moraine snout. Pedestal rocks, snow pockets in clefts near snout.

5 Steep, fluted headwa11. Bergschrund, crevasses, banded ice, and pedestal rocks. V-shaped, sharp-crested end moraine, discharge from near crest. 
APPENDIX 1.--Description of items in tables 1 and 2--Continued

6 Really two cliff glaciers under Palisade Crest, share some headwall and same sinuous end moraine with sharp crest and steep front. Steep, fluted headwa11, bergschrund, crevasses, pedestal rocks. Discharge from crest of the $\mathrm{E}$ snout. Both snouts discharge into Elinore Lake.

7 Steep, fluted headwall. Good bergschrund cuts ice-filled chutes. Cliff ice-pockets nearly connect with glacier to the SE. Banded ice, pedestal rocks, tongue-like snout terminates in lakelet.

8 Ice pocket with ice-filled chute on $\mathrm{N}$ side of Mt. Sill. Few cracks, lumpy moraine.

9 Ice pocket with tiny moraine occupies cleft on NE side of Mt. Gayley. Cracks, tiny moraine.

9.1 Avalanche snow accumulation.

10 Ice pocket or tiny glacierette occupies niche on $\mathrm{N}$ side of Mt. Gayley. Cracks. Sinuous, sharp-crested moraine.

11 Palisade Glacier. Largest glacier in the Sierra. Occupies giant cirque between Mt. Sill, North Palisade, and Mt. Winchell. Huge bergschrund, crevasses, ice-filled chutes. E snout has pond, arcuate, high moraine. W snout is rock mantled and has high moraine. Terminates in Robin's Egg Lake.

11.1 Snow lies on fairly flat area perched high above the $N$ side of North Palisade.

11.2 Remnant snow ring lies under moraine front.

11.3 Snow-ice pocket lies in cleft (part of snow ring) on NW side of east lobe of Palisade Glacier. 
APPENDIX 1.--Description of items in tables 1 and 2--Continued

11.4 Steep snow in cleft.

11.5 Steep snow ice. Few cracks, rock accumulation too steep for moraine crest to form.

11.6 Snow ring under end moraine of Winchell Glacier.

12 Occupies Mt. Winchell's $N$ cirque. Bergschrund cuts ice-filled chute. Cracks, banded ice, pedestal rocks, sharp-crested moraine. Associated cliff ice just to the E.

12.1 Snow accumulation in cleft. Gray, has wrinkles.

12.2 Snow or ice in cleft above San Mack Lake.

12.3 Snow or ice pocket in cleft above Sam Mack Lake. Several shades of snow, tiny cracks. Terminates at edge of pond.

12.4 Ice pocket. Has tiny moraine.

13 Tiny glacierette occupies niche above lake. Snow-filled chutes, moraine.

13.1 Snow ring along the SE side of Agassiz Glacier.

14 Agassiz Glacier in N cirque of Mt. Agassiz. Bergschrund cuts ice-filled chutes. Banded ice, pedestal rocks, long, looping, mantled, ice-cored body. Steep, low front. Snow ring in the moat area.

14.1 Snow patches in clefts and under wall.

14.2 Snow accumulation in niche. Terminates in tiny pond.

15 Tiny glacierette below peak. Ice-filled chutes. Rock-mantled, lumpy, inflated look. Steep front.

15.1 Snow-filled chutes, dirty ice. Sharp-crested moraine with front.

15.2 Snow-filled chute. Dirty ice, rock mantle to moraine front. Deflated moraine material below. 
APPENDIX 1.--Description of items in tables 1 and 2--Continued

16 Remnant cirque glacierette under peak. Cracks in headwall ice, pedestal rocks, ice-filled chutes, steep front. Deflated moraine below with little or thin interstitial ice.

1 Glacierette in cirque at $N$ end of the Inconsolable Range. Staircase of morainal ridges, all arcuate and steep. Possible ice-filled chutes.

1.1 Tiny ice accumulation with moraine and front.

2 Ice-filled chutes charge inflated, mantled rock glacier. Active front.

3 Shallow glacierette or drift snow. Terminates in pond in back of low arcuate moraine.

3.1 Snow accumulation, part of glacier 3. Shares same end moraine.

4 Glacierette occupies niche under peak. Has small bergschrund-like headwall crack.

4.1 Ice descending from tiny cirque. Long, slightly curved snout, front terminates onto $S$ end of Bishop Lake.

5 Bowl-like glacierette occupies cirque on E side of peak. Small, ice-filled chute, cracks(?). Moraine front.

6 Dirty glacierette in niche on NE side of Mt. Goode. Very spectacular "stair-stepped" (about 16) broad arcuate ridges making up a funnel-shaped rock glacier. Steep fronts.

7 Wide cliff glacier. Wide bergschrund $(800 \mathrm{~m})$ cuts many ice-filled chutes. Crevasses, pedestal rocks, complex moraines. Front spills over shelf onto the edge of rock glacier below. Discharge from crest of moraine. 
APPENDIX 1.--Description of items in tables 1 and 2--Continued

7.1 Snow/ice pocket just above a lake.

7.2 Snow/ice pocket alongside feature 7.3. Moraine front.

7.3 High perched ice pockets under cliff. Some moraine, but rounded crest.

8 Small headwall niche glacier above lake. Ice-filled chutes, few cracks, pedestal rocks. Low, acruate moraine. Associated ice pockets to the NE.

9 Glacier and steep ice-filled chutes. Much rock mantle, few pedestal rocks, double snouts. Steep front spills talus into pond below.

9.1 Cliff ice. Few cracks, rock accumulation.

10 Mt. Gilbert glacier. Wide glacier with wide bergschrund cutting ice-filled chutes. Banded ice, pedestal rocks, crevasses, looping morainal ridges, pond in depression. Narrow, low front spills into lakelet.

11 Occupies cirque on $\mathrm{E}$ side of Mt. Thompson. Huge bergschrund cuts ice-filled chutes. Crevasses, pedestal rocks, banded ice. Long, flowing, narrowing snout butts against the glacier snout just to the E. Lateral moraine spills talus over slope to lakelet below.

11.1 Snow chute in eroded joint.

11.2 Cliff ice in shallow cirque.

12 Glacierette on $N$ side of peak.

13 Wide headwall glacier with two snouts in cirque on NW side of Mt. Thompson. The $W$ snout just above Sunset Lake, the $E$ snout butts against the former. Large bergschrund, banded ice, pedestal rocks, crevasses. Discharge from crest of the $E$ snout, $W$ snout is rock mantled. 
APPENDIX 1.--Description of items in tables 1 and 2--Continued

14 Small glacier with ice-filled chute, occupies niche on the $\mathrm{E}$ side of peak above Sunset Lake. Banded ice, cracks. Discharge from crest of the moraine.

14.1 Snow patch in shallow cleft.

14.2 Snow accumulation in cleft above moat area. A partial broken snow ring persists in moat area also.

14.3 Dirty snow or ice accumulation.

15 Powell Glacier. Bergschrund cuts ice-filled chutes, banded ice, pedestal rocks, snow rings in the moat. Rock-mantled, inflated, ice-cored snout. Steep sharp-crested front spills talus to basin floor just above Moonlight Lake. The longest glacier in the Sierra from bergschrund to front.

15.1 Snow patches in front area of Powell Glaciex.

15.2 Partial snow ring in moat area.

15.3 Snow accumulation under steep wall.

15.4 Snow or ice accumulation in cleft. Connected to feature 15.7 below.

15.5 Shallow part of glacier 15.

16 Glacier SE of Echo Lake. Upper areas may be shallow, floor outcrops through snow(?). Debris mantle. Discharge from crest of moraine. Two associated ice or snow pockets to the $W$ and below.

16.1 Snow patches terminating at edge of Echo Lake.

17 Small glacier occupies cirque due $\mathrm{S}$ of Echo Lake. Pedestal rocks, much dirty mantle. Sharp-crested moraine crest spills talus into the upper end of Echo Lake. Several more associated snow pockets above Echo Lake. 
APPENDIX 1.--Description of items in tables 1 and 2--Continued

17.1 Cliff ice above Echo Lake. Dirty talus goes into lake.

17.2 Cliff ice in same cirque as 17.1. Dirty ice, rock bottom.

18 Cliff ice and glacierette under peak. Few ice-filled chutes. Snout with steep, low front terminates in pond on shelf above Echo Lake.

18.1 Snow patches.

19 Bowl-like glacierette occupies the SE cirque of Mt. Haeckel. Lakelet with bergs lies upon the lower ice areas. Low moraine.

19.1 Dirty ice accumulation, ice-filled chute. Small moraine front runs into lake.

19.2 Dirty ice, cliff accumulation. Snow-ice filled chutes. Debris goes into lake.

19.3 Snow patches in clefts.

20 Glacier in cirque just SW of Hungry Packer Lake. Ice-filled chute, cracks, much rock mantle. Steep arcuate front.

20.1 Snow ring accumulation around sides and base of glacier 29.

21 Small glacierette on NE side of Mt. Haeckel. Crack in upper area, pedestal rocks, narrow, arcuate maraine. Snow ring surrounds entire body. Older deflated moraine below.

22 Ice-filled chutes, main glacier terminates into a lake. Another part forms tiny arcuate moraine which spills talus into the SE part of the lake. Deflated moraine below the lake.

22.1 Snow patch.

22.2 Snow accumulation under cliff. Cracks.

22.3 Snow accumulation in $\mathrm{E}$ moat area of glacier 23 . 
APPENDIX 1.--Description of items in tables 1 and 2--Continued

23 Small glacier due S of Blue Heaven Lake. Bergschrund, crevasses, pedestal rocks, mantle. Steep, squared-off front.

24 Cliff glacier under Mt. Darwin's SE headwall. This moraine merges with that of the Blue Heaven Lake glacier. Has pedestal rocks, much mantle. Steep front.

24.1 Ice patch. Moraine front spills into lakelet below.

24.2 Snow patch.

25 Small glacier(?) above Schober Lakes and on the $N$ side of peak. Several ice-filled chutes. Double arcuate front?

25.1 Snow patch.

25.2 Snow or ice pocket in niche under cliff.

25.3 Snow patches lie in shallow through NE of Lamarck Col.

25.4 Steep snow or ice in cleft, same trough as feature 25.3.

25.5 Snow in niche under NE side of Lamarck Col. Pond below.

25.6 Cliff snow accumulation in SE moat area of Lamarck Glacier.

26 Lamarck Glacier. Wide, ice-filled chutes. Large bergschrund, crevasses, pedestal rocks, much rock mantle, flow-looping ridges. Concave upper part, convex lower half.

27 Glacier along side Lamarck Glacier. Small bergschrund, pedestal rocks, inflated look, looping ridges. Low, steep front.

27.1 Ice-rimmed pond.

27.2 Cliff snow or ice accumulation. Dirty ice in chutes.

27.3 Cliff ice pocket lies under ice-filled chute. Tiny moraine. 
APPENDIX 1.--Description of items in tables 1 and 2--Continued

28 Small cliff glacierette occupies niche on $N$ side of arete SW of Wonder Lakes. Low moraine. Associated cliff ice approximately $1 \mathrm{~km}$ wide.

29 Bergschrund cuts wide ice-filled chute, with head in broadening summit cornice. Thick, broad, looping, rock-mantled lobate front. Discharge from crest of steep front. Discharge from crest of steep front suggests thick buried ice core beneath shallow protective rock mantle.

30 Small glacier, two ice-filled chutes, inflated, rock-mantled body. Sinuous but low front terminates just above Emerson Lake. Older deflating moraines below.

30.1 Snow patches in joints, upon ledges, etc.

31 Cliff ice or remnant glacier on NW side of Mt. Emerson (rock glacier?). Ice in chutes, few cracks. Dirt and rock mantle conceal more ice. Flow-like moraine loops.

31.1 Headwall ice, ice-filled chutes. Rock mantle.

31.2 Remnants of rock glacier with few snow patches and some ice in chutes. Mostly deflated areas.

4216

1 Fairly large glacier. Bergschrund, crevasses, ice-filled chutes, few pedestal rocks. Rock mantle shows arcuate ridges of darker rock. Steep ice-cored front. West area at base of front.

2 Glacierette perched high in cleft of large cirque, SE side of Mt. Humphreys. Trace of bergschrund. Discharge from crest of moraine. Talus from crest to basin floor. 
APPENDIX 1.--Description of items in tables 1 and 2--Continued

2.1 Dirty snow or ice in cleft just $E$ of Humphreys Glacier. Has a tiny moraine.

3 The main part of the Mt. Humphreys Glacier. One common headwall ice body with two snouts. A large bergschrund cuts several ice-filled chutes. Several shades of snow to bare, structurally banded glacial ice. Pedestal rocks, surface mantle with two circular collapse cracks in back of the front.

4 This glacier heads in the same cirque headwall as glacier 3 , but is detached near upper areas and flows downward separately. Cracks cut off ice-filled chutes, several shades of snow to ice. Stream issues from crest of moraine front. A snow patch with cracks lies in cleft just $\mathrm{N}$ of the glacier.

5 Thin glacierette with three parts, connected by narrow necks of snow. Lies in a gently sloping, high-perched narrow cleft with a low headwall on the $W$ side. Several shades of snow. Discharge stream issues from under the lowest edge.

5.1 Snow in pocket at the head of a shallow cirque. Nivation cirque forming?

5.2 Many snow patches and little ice pockets lie under cliffs, upon ledges, etc.

6 Small pear-shaped glacier. Appears shallow, much rock mantle, few cracks in upper area. Narrow moraine front.

7 Glacier above Horton Lake. Bergschrund cuts several ice-filled chutes, crevasses, pedestal rocks, looping ridges. Lobate front spills into lake. 
APPENDIX 1.--Description of items in tables 1 and 2--Continued

7.1 Snow accumulation in cleft along lobe of glacier. Possibly frozen pond.

8 Four Gables Glacier. Bergschrund cuts ice and talus. Ice-filled chutes, pedestal rocks, looping surface ridges, snow rings around main body. Nearby headwall snow just to $W$.

8.1 Ice pocket detached from Foux Gables Glacier, but same cirque. Two shades of snow.

8.2 Snow ring fills moat on both sides of glacier.

9 Headwall ice pockets with two main ice-filled chutes. Common moraine front.

10 Small glacierettes (ice-filled chutes?). Cracks in ice. Long rock-mantled, narrow front.

11 Ice pocket in cirque with inflated body, steep front. Rock glacier descends from $\mathrm{N}$ headwall area.

12 Dirty glacierette under step shady headwall. Bergschrund?

13 Dying glacier, ice-filled chutes. Much rock mantle, long looping ridges on inflated body. Steep front terminates near stunted trees. (Rock glacier extension?)

13.1 Ice pocket perched high in a shallow cirque. Three shades of snow.

13.2 Eroded joint filled with ice or snow.

13.3 Ice pocket. Several shades of ice. Small moraine.

14 Small glacierette lies in headwall niche above Granite Park. Ice-filled chutes, cracks, steep front. Discharge from base.

15 Ice pocket or glacierette under Granite Park's headwall. Small moraine. Discharge from base of moraine.

15.1 Snow patches occupying depression behind moraine. 
APPENDIX 1.--Description of items in tables 1 and 2--Continued

16 Ice accumulation. Ice-cored, rock-mantled tongue with lobate front. Part of glacier 17.

17 Headwa1l or dying cliff glacierette. Inflated, rock-mantled snout with steep front. Part of 16.

17.1 Tce pocket in niche with several shades of snow or ice. 4217

0.1 Snow in cirque.

0.2 Snow and ice in chutes. Rock glacier(?) below.

1 Mostly rock glacier. Some headwa1l ice, snow-filled chutes.

1.1 Snow or ice patches occupying niches under shady headwall.

2 Glacierette? Cracks in headwall area, several shades of snow. Lumpy, steep moraine.

2.1 Snow or ice patches at base of front of glacier 5 .

2.2 Snow or ice patches.

2.3 Snow or ice occupying eroded joints in granitic rock.

3 Small glacierette. Cracks, may be connected at the headwall to glacierette just to $W$. Sharp moraine front.

4 Small glacierette with same headwall as glacier just to E.

5 Small steep glacier. Sharp-crested moraine. Long talus front spills to lake below.

5.1 Small ice pocket with tiny sharp-crested front.

5.2 Snow or ice patches with several shades of snow or ice.

6 Remnant cirque glaciex on SSE side of Mt. Dade. Thin, steep ice sheet plunges into lake. (Probably on ice core.) "Dam-like" moraine spills talus cone to basin floor. 
APPENDIX 1.--Description of items in tables 1 and 2--Continued

7 Large glacier. Wide bergschrund, banded ice, pedestal rocks, ice-filled chutes. Sinuous, sharp moraine with discharge from crest. Ice probably connects with Abbot Glacier just to the N.

7.1 Tiny ice pockets with front under steep headwall.

8 Glacierette in shady cirque. Cracks, pedestal rocks, small bergschrund. Talus spills to lakelet below. Ice-core collapse at crest of front.

9 Headwall glacier. Bergschrund cuts ice-filled chutes, cracks, pedestal rocks, much rock-mantle. Long, tapering, looping, ridged snout with pond on surface. Low but steep front. Lake below filling in.

10 Thin, dying glacierette in cirque above Ruby Lake. Ice-filled chute, some dirty ice. Moraine, steep talus front.

11 Small moraine crest.

11.1 Ice pockets under cliff. Several tones of snow and ice.

12 Small glacier. Cracks, pedestal rocks, with long curving rock-glacier extension which terminates near Steelhead Lake.

13 Glacierette in narrow cirque with long rock-glacier snout. Butts against and joins front of feature to the E. Dirty ice at head, several shades of snow.

13.1 Headwall ice behind sharp-crested moraine.

14 Glacierette in steep cirque of Mt. Crocker. Dirty ice, pedestal rocks(?), several shades of snow. Small acruate moraine.

14.1 Small ice pockets hugging headwall.

15 Ice pocket in niche on SE side of Red and White Mt. Several shades of snow. 
APPENDIX 1.--Description of items in tables 1 and 2--Continued

16 Small dyig rock-mantled glacierette on NE side of Red and White Mt. Headwall ice, sharp-crested moraine of dark and light-colored rocks, steep front. Inflated ice core.

17 String of snow or ice pockets in long cleft. Front talus spills into lake.

17.1 Snow and ice nearly filling lake. Arcuate crack where ice is calving off into the lake.

17.2 Buried ice core?

17.3 Buried ice core?

17.4 Ice pocket with tiny moraine.

17.5 Ice pocket on talus material beind sharp-crested moraine.

17.6 Snow patch on talus.

17.7 Possible rock glacier. Buried core?

17:8 Snow in chute.

18 Snow or ice accumulation in cirque.

19 Ice-filled chutes on N side of Mt. Morrison. Come together at small moraine?

20 Small glacier above Constance Lake. Bergschrund cuts ice-filled chutes. Crevasses, inflated, rock-mantled lobate moraine.

21 Glacier on N side of Red Slate Mt. Barely detached from the glcier just to the E, some cracks, small bergschrund. Sharp-crested moraine.

22 Small glacier with bergschrund cutting ice-filled chutes. Sinuous moraine with $V$-snout is shaxp crested, spills talus into Constance Lake.

22.1 Snow accumulation with dirty snow-ice, fluted by erosion. 
APPENDIX 1.--Description of items in tables 1 and 2--Continued

22.2 Cluster of snow and ice patches on talus at base of narrow trough.

22.3 Snow-ice accumulation on metamoraphic rock.

22.4 String of ice pockets hugging steep headwall.

22.5 Small snow and ice patches. Moraine with pond below front.

22.6 Dirty snow patches behind slightly inflated moraine.

22.7 Rock glacier? Thin mantle of fine, dark metamoraphic rock on ice, several cracks on surface near the bergschrund. Sharp-crested moraine. Several older moraines with trees lie below the present active front. Several ice- or snow-filled chutes.

22.8 Small ice pocket behind sharp-crested moraine.

22.9 Small headwall ice pockets in niches.

22.10 Headwall ice pockets and dirty snow at head of glacier 22.12.

23 Dirty ice or snow in shallow cirque with small discharge from below terminus.

24 Cliff ice accumulation under headwall. Behind small moraine?

24.1 Snow patches lie above active moraine front behind possible deflated rock glacier. Trees growing on surface, small lake at terminus.

24.2 Ice pockets fluted by erosion. Lie behind moraine front.

25 Small niche glacierette. Has ridges, possible cracks near headwa11. Terminus narrows. Small moraine.

25.1 Ice pocket with dirty ice above steep-fronted moraine. Partially covered by trees on eastern flank.

25.3 
APPENDIX 1.--Description of items in tables 1 and 2--Continued

4221

0.1 Several snow patches under steep slope.

0.2 Several snow patches under steep slope.

1 Glacier. Small bergschrund. Moraine accumulation.

2 Snowfield lying at base of glacier moraine.

3 Mt. Davis glacier. Trace of bergschrund, bare ice with rings.

3.1 Snow patches in niches near front of Mt. Davis glacier.

4 Glacier. Several shades of snow and ice. Lateral-like moraine on $W$ side with snow ring filling moat. End moraine terminates into Davis Lake.

4.1 Cluster of snow-ice pockets lying in niches.

5 Glacierette with snow cover spilling over end moraine and terminating in small pond.

5.1 Snow patch in niche.

5.2 Snow patch in niche.

5.3 Snow patch in niche.

5.4 Snow or ice pocket in niche.

5.5 Snow patch on shelf.

5.6 Snow patch.

5.7 Small snow patches persist in joints, niche, etc.

6 Glacier. Two shades of white, snowfield partially over end moraine.

7 Probably accumulation glacierette, just above Lake Marie.

8 Snow ice pocket perched in shallow cirque.

8.1 Cluster of shallow snow patches lying on slope. 
154 Inventory of Glaciers in the Sierra Nevada, California

APPENDIX 1.--Description of items in tables 1 and 2--Continued

9 Wide, shallow headwall glacierette. Small crevasse at headwall. Moraine spills over steep slope.

9.1 Snow patches in small niche.

9.2 Snow patches.

9.3 Snow accumulation.

9.4 Snow lying in eroded joint.

9.5 Snow patch.

10 Glacierette? A rock glacier-1ike moraine with many narrow loops.

10.1 Steep ice wall terminating in Upper Marie Lake. Bergschrund-like crevasses above water.

11 Snowy glacier. Some crack in lower area. Terminates in pond. Thin moraine below.

12 Small glacier in shallow cirque. Some moraine material.

12.1 Snowfield lying upon a perched, gentle slope above glacier 13.

13 Fairly large glacier ESE of Mt. Lyell, head under cirque headwall. Bergschrund, many bands show with a few crevasses. Pond on ice surface in back of moraine front.

13.1 Snow patch?

13.2 Snow patch.

13.3 Snow accumulation under headwall, several snow-filled chutes. Terminates in lake.

13.4 Snow accumulation lies behind tiny moraine under shady cirque headwall. Snow patch below.

14 Small, shallow glacierette. Several shades of snow. Small arcuate moraine front terminates in Upper Alger Lake. 
APPENDIX 1.--Description of items in tables 1 and 2--Continued

15 Pond at terminus. New steep moraine forming higher up.

15.1 Snow accumulation under shady cliff. Several shades of snow. Terminates in pond.

0.1 Snow patch. Shallow nivation cirque possibly forming.

1 Shallow glacierette in Parker pass. Several shades of snow. Some fine-textured surface accumulation, trace of moraine. Nivation cirque possibly forming.

2 Solid but shallow glacierette in Parker Pass. Several shades of snow ice. Nivation cirque possibly forming.

3 Westermost Parker Pass Glacier. Bergschrund, banded ice, sharp arcuate moraine.

3.1 Snow pocket.

4 Small cliff glacierette. Cracks in headwall area, several shades of snow or ice.

4.1 Cluster of many snow patches which lie in clefts, upon ledges, etc.

4.2 Snow patches in clefts, niches, etc.

4.3 Snow or ice pocket in niche. Several shades of snow.

4.4 Snow pocket and several snow patches in shady niche. Several shades of snow.

5 Kuna Glacier. Large bergschrund, several shades of snow, crevasses, pedestal rocks. Multiple-ridged moraine. 0lder deflated moraines below.

5.1 Snow ring in front of Kuna Glacier moraine. Terminates in large snow patch.

5.2 As above, but on $W$ part of snout under wall. 
APPENDIX 1.--Description of items in tables 1 and 2--Continued

5.3 Ice patch with snow-filled chute. Moraine crest with front terminating in pond below.

6 Glacier high in shallow cirque on NE side of Mt. Gibbs. Arcuate moraine.

4223

1 High perched glacierette nearly at crest. Small, sharp-crested moraine loop.

2 Commonly called a rock glacier. Photo shows bare ice terminating into lake with a thin covering of rock.

2.1 Snow and cornices at headwall crest above glacier 2 .

2.2 Snow and dirty ice in chutes $\mathrm{E}$ of Dana Glacier.

3 Glacierette? Has moraine.

4 Glacierette? Has moraine.

5 Dana Plateau Glacier. Bergschrund. Moraine front, with long thin waterfall descending.

5.1 Snow ring fills moat area on both sides of glacier 5 .

5.2 Snow or ice at head of cirque, NW side of Dana Plateau.

6 Dana Glacier. Huge bergschrund, much crevassed ice, ice-filled chute, pedestal rocks, steep front. Lobate moraine.

7 Thin ice accumulation of Dana Glacier. Talus cone separates from main glacier. Two shades of ice in chute.

\subsection{Snowfield?}

7.2 Snow lodged in deep, narrow gully.

7.3 Many snow patches lying in clefts, niches, and upon narrow ledges. 
APPENDIX 1.--Description of items in tables 1 and 2--Continued

7.4 Snowfield lying in niche on slope. Has snow-filled chute connecting with glacierette lying above. Two shades of snow are visible.

8 Glacierette. Trace of bergschrund, two tones of snow.

8.1 Snowfield lying in cleft upon slope (nivation?).

8.2 Ice pocket lying in niche just under a saddle.

8.3 Ice pockets under steep headwall. Central feature has a tiny moraine.

8.4 Small ice pocket lies under steep cirque headwall.

8.5 Small ice pocket lies under steep cirque headwall.

9 Glacierette fills niche in cirque. Several shades of snow, cracks in upper area. Arcuate moraine terminates in tiny pond.

9.1 Dirty snow accumulation with some narrow, dark snow-filled chutes above.

10 Shallow glacierette. Sma11, arcuate moraine.

10.1 Headwall snow patches.

11 Shallow glcierette high on ridge, part under headwall. Several shades of snow. Possible small moraine.

12 Glacierette. Cracks in upper area, several shades of snow.

12.1 Ice pocket lies under shady headwall. Several shades of snow.

13 Cliff glacierette under shady cirque headwall.

13.1 Small rock glacier. Some surface ice, flow, front.

13.2 Ice pocket lies in niche of the Mt. Conness headwall.

14 Headwall glacierette. Cracks, several shades of snow. Tiny arcuate moraine, irregular.

14.1 Snow accumulation under cliff. 
APPENDIX 1.--Description of items in tables 1 and 2--Continued

15 Mt. Conners Glacier. Large bergschrund, both lobes have banded ice, crevasses. E lobe shows cirque floor in back of moraine? Detached moraine. Both parts are classed as one glacier.

4224

0.1 Probably permanent snow in high cleft.

1 Glacierette. Several shades of snow, inflated look, rock mantle.

1.1 Several shades of snow, rock mantle, front.

1.2 Snow patches.

2 Glacierette? Appears deep, several shades of snow.

3 North Peak Glacier. Many cracks in upper areas. Several shades of snow. Well-developed end moraine.

3.1 Snow-ice pockets fill narrow niche.

3.2 Snow patches in clefts and saddles of a shallow cirque. Some look deep and straddle the stream.

3.3 Ice pocket lies under shady cliff. Some cracks or wrinkles. Moraine extends below.

3.4 Snow patch in shallow cirque.

3.5 Snow patch in shallow cirque.

4 Tiny glacierette in small shallow cirque.

5 Glacier in cirque on NNE side of Excelcior Mt.

0.1 Snow patch in shallow cirque.

0.2 Snow under steep cliff S of Blackrock Lake.

0.3 Snow patches in niches under steep headwall. 
APPENDIX 1.--Description of items in tables 1 and 2--Continued

4311

0.1 Snow or ice in headwall cleft.

0.2 Snow streak under joint in headwall.

1 Glacierette in cirque $W$ of Finger Peak. May be only glacier in $\mathrm{N}$ Fork Kings River. Snow-filled chute, arcuate moraine, steep front.

1.1 Snow patches under cliff.

1.2 Snow or ice in niche. Snow-filled chute above, moraine(?) below. 4312

0.1 Headwa11 snow.

0.2 Headwall snow.

0.3 Snow patches, accumulation under cliff.

0.4 Snow patches in north headwall. Largest appears to have tiny moraine-like rock accumulation.

0.5 Snow pocket $N$ side of a Col.

0.6 Snow or ice pocket lying in same narrow trough a snow pocket 0.5 .

0.7 Tiny snow patches under cliff.

0.8 Snow accumulation under cliffs of Blue Canyon Peak. The westernmost feature has a moraine with usual front.

0.9 Snow or ice accumulation under $\mathrm{E}$ part of Finger Peak headwall.

1 Cliff ice or remnant headwall glacierette on $\mathrm{N}$ side of Finger Peak.

1.1 Snow streaks in clefts or joints lie in shaded area of cirque.

1.2 Small snow or ice pocket. Suggestion of small rock spillage.

1.3 Cliff ice or snow accumulation. Several shades of snow.

1.4 Snow patches under steep slope S side of Mt. Goddard. 
APPENDIX 1.--Description of items in tables 1 and 2--Continued

1.5 Snow patch lying in niche.

1.6 Snow patch in cleft at $S$ end of long unmapped lake.

1.7 Snow accumulations in eroded niche.

1.8 Snow in clefts and niches.

2 Glacierette or ice pocket. Calves off into lake. Ice wall about three meters high.

2.1 Ice pocket in shallow cleft. Small cracks, several shades of snow. Moraine-like material but too steep for formation of a front.

3 Small glacier in niche on $\mathrm{N}$ side of peak. Cracks, steep ice, rock mantle.

3.1 Snow or ice in cleft below steep slope. Few cracks.

4 Small glacier on ragged spur in shallow cleft. Cracks in ice, sharp crest. High, steep talus front.

4.1 Snow-ice pocket in cleft above talus cone and headwall. Few cracks. Rock accumulation at base.

5 Small niche glacier on ragged spur on E side of peak. Cracks in ice. Sharp crest, talus is high and steep.

5.1 Snow patch at base of The Sirens.

5.2 Snow-filled eroded cleft.

5.3 Snow-filled eroded cleft.

6 Scylla Glacier. Odd-shaped double glacier on $\mathrm{N}$ side of Scylla Peak. Small bergschrund in $W$ upper part, steep ice and moraine snout spills onto lower part to the E, small bergschrund again. Snow-filled chutes, pedestal rocks. Sharply-crested moraine. 
APPENDIX 1.--Description of items in tables 1 and 2--Continued

6.1 Snow at base of moraine.

7 Small ice accumulation in cleft on NW side of peak. Associated snow patches lie in clefts and eroded joints.

7.1 Snow patch.

7.2 Snow patches occupy eroded slope area between contact of Alaskite and sheared granitics.

8 Charybdis Glacier. Much rock-covered ice. Several tongues spill into Ionian Basin from a common headwall ice accumulation.

8.1 Snow patch.

8.2 Snow in cleft.

8.3 Snow in cleft.

8.4 Snow patch.

9 Glacierette on NW side of Mt. McDuffie. Cracks, ice-filled, chuted, rock-mantled steep front.

9.1 Snow or ice, part of talus front. Crack across front.

10 Perched snow field lies in saddle on NE side of wheel Mt. Appears deep and permanent.

10.1 Ice pocket in niche on $W$ side of Wheel Mt.

10.2 Snow pocket at head of tiny cirque, Much rock, dirty ice. 4313

1 Narrow glacierette lies in niche between Mt. Woodworth and Peak 11858. Narrow front.

1.1 Tiny ice pocket. Lies under steep headwall under Mt. Woodworth. Cracks in headwall ice. Sharp-crested moraine front of dark, fine-textured rocks. 
APPENDIX 1.--Description of items in tables 1 and 2--Continued

1.2 Ice pocket under cliff. Several tiny cracks. Tiny moraine of same description as above.

1.3 Dirty ice patch. A small bergschrund. Snout with arcuate front.

1.4 Snow patch in moat area of above glacierette.

2 Sma11 cliff glacierette. Few cracks. Talus spills into lake below.

2.1 Snow or ice pocket below the Devils Crags glacierette. Possibly tied to glacierette above, but thin layer of fine-textured dark rock mantles the connecting ice. Too steep for a sharp-crested moraine.

2.2 Ice pocket, partially rock covered. Terminates in lake at head of Rambaud Creek.

2.3 Dirty snow that belongs to a folded-looking talus accumulation. Tiny front, probably some ice core.

2.4 Snow patches under cliffs of The Citadel.

2.5 Tiny, dirty ice pocket perched in cleft on NW side of The Citadel. Tiny, moraine-like rock accumulation.

2.6 Some dirty rock-covered ice in upper areas. Long snout with five or more steps above the front.

2.7 Small ice pockets. Easternmost has ice with rock-covered tongue and front.

3 Small cirque glacierette occupies small cirque just $S$ of peak. Few cracks. Tiny sharp-crested moraine.

3.1 Shallow cliff ice accumulation. Dirty ice. 
APPENDIX 1.--Description of items in tables 1 and 2--Continued

4 Cirque glacier. Bergschrund cuts ice-filled chutes, has cracks and pedestal rocks. A rock-mantled, inflated body. Sharp crest spills talus into pond below.

4.1 Snow pocket (remnant snow ring) lies in moat area on NW side of glacier 4.

4.2 Steep ice pocket under headwall. Several shades of ice. Terminates in lake.

5 Cliff glacierette just to $W$ of Ladder Lake. Some cracks, ice-filled chutes. Sinuous moraine crest spills talus into ponds below.

5.1 Chutes (joints). Cracks or wrinkles in ice. Probably all parts connected under a thin rock mantle. All share the same sinuous end moraine with steep front.

6 Fairly large glacier occupies shallow cirque. Bergschrund, crevasses. Sinuous, sharp-crested moraine spills talus over long steep front to lake below.

6.1 Snow or ice cliff accumulation.

7 Glacierette perched upon shelf under cliff on $N$ end of peak. Moraine crest. Front spills into lake.

7.2 Steep snow patch. Tiny moraine-like rock accumulation, but too steep for a sharp-crested moraine front.

7.3 Ice pockets lie in clefts under cliff on Langille Peak.

7.4 Ice pocket under Langille Peak headwall. Cracks in ice or snow. 
APPENDIX 1.--Description of items in tables 1 and 2--Continued

8 Small glacier. Many rock-mantled, looping ridges, low but steep front. Possible rock glacier, although large ice core.

9 Dying cliff glacier occupies $S$ end of basin E of the Black Giant. Dirty, rock-mantled. Crest and steep front.

10 Two glaciers possibly connected under headwall by interstitial ice. Trace of bergschrund, cracks, chutes. Double, steep sinuous front on the main glacier to the SE. Steep front spills dark, fine-textured talus to basin floor.

11 Small glacier occupies narrow cirque on ESE side of the Black Giant. Multiple cracks in bergschrund area, debris spills onto the dirty ice. Sharp-crested front spills talus to basin floor.

12 Largest glacier on the Black Divide. Wide bergschrund, banded ice, crevasses. Discharge from crest of moraine, talus spills to basin floor.

13 Small niche glacier. Cracks in ice. Sharp-crested moraine spills talus to a shelf below.

14 Sma11 glacierette. Few cracks in upper area, arcuate front.

14.1 Snow or ice pocket. Two shades of snow-ice. Terminates in tiny, partially-frozen unmapped lake.

14.2 Small cliff ice accumulation. Tiny moraine accumulation, front terminates in unmapped lake.

14.3 Snow patches $\mathrm{S}$ of Helen Lake. Largest shows rock accumulation.

14.4 Snow patches. Largest one terminates in the upper end of a lakelet. 
APPENDIX 1.--Description of items in tables 1 and 2--Continued

15 Smal1 cliff glacierette due $S$ of Helen Lake. Moraine front

terminates at the lake. Ice-filled chutes.

15.1 Snow pocket. Smal1 moraine?

15.2 Snow or ice pocket. Small moraine?

15.3 Snow patches.

15.4 Snow patch in cleft above lake.

15.5 Snow patches.

16 Tiny rock-mantled glacierette. Dirty, ice-filled chutes.

Inflated body. Low, steep front terminates in lake. Bare

ice and snow terminates in unmapped pond to the NW of the

lake. Pure ice core?

16.1 Dirty, bare ice associated with glacier 16. Terminates in sma11 unmapped lakelet.

16.2 Snow patch. Ice in chute and partially rock-covered ice terminates in lake.

17 Tiny glacierette? Few cracks. Moraine terminates in pond.

17.1 Snow cornice on saddle crest above glacier 17 .

17.2 Snow accumulation. Has moraine.

17.3 Snow in niche.

17.4 Moraine lies between snow and lakelet, but may be older.

17.5 Snow accumulation cone under chute. Few cracks.

17.6 Snow or ice accumulation under cliff. Dirty.

17.7 Snow ice accumulation. Small moraine-1ike accumulation.

18 Tiny glacierette(?) with moraine under $\mathrm{N}$ cliff of Isoceles Peak.

18.1 Ice patch. Moraine. 
APPENDIX 1.--Description of items in tables 1 and 2--Continued

19 Small glacierette or rock glacier. Sharp crest.

20 Small glacierette $N$ side Giraud Peak. Much rock mantle, sharp front.

21 Small cliff glacierette. Cracks in upper areas, much rock mantle. Sma11 moraine.

22 Glacierette in chute lies above Rainbow Lake. Small front.

23 Ice pocket with rock mantle and steep front lies above the Western Rainbow Lakes.

23.1 Snow below glacier 23. Shares same moraine front. 4314

1 Shallow glacier in a high-perched saddle. May be the highest glacier in the Sierra. Tiny moraine. Source of Glacier Creek.

1.1 Snow in chute.

2 Cracks, trace of bergschrund? Moraine.

3 Crevasses.

3.1 Snow patch.

3.2 Snow patch?

3.3 Snow or ice pocket. Tiny moraine descends.

4 Small glacierette occupies tiny cirque on E side of Observation Peak. Heads in col. Small, narrow moraine front.

5 Glacierette occupies narrow cirque on $W$ side of Observation Peak. Steep, small moraine front. Snow fills joint below.

6 Ice pocket occupies cirque on SE side of Mt. Shakespeare. Dirty ice and lumpy moraine.

6.1 Snow patch. 
APPENDIX 1.--Description of items in tables 1 and 2--Continued

6.2 Snow patches.

6.3 Snow pocket? Tiny moraine.

6.4 Snow patch?

7 Glacierette with moraine occupies cirque above the westernmost Dumbe11 Lake. Cracks in ice. Sharply-crested, long talus front.

7.1 Snow patch under headwal1.

7.2 Very small snow patches. Tiny moraine into lake.

7.3 Headwa11 ice.

7.4 Three cliff ice pockets. Two show some small arcuate moraine accumulations .

7.5 Cliff snow accumulations.

7.6 Cliff snow accumulations.

8 Remnant cliff glaciertte in crest of cirque on $\mathrm{N}$ side of peak.

Talus terminates in pond.

9 May be two glaciers side by side under cliff. Moraine?

10 Small glacierette in steep, shady cirque headwall. Moraine.

10.1 Ice pocket in niche. Moraine.

10.2 Snow or ice pocket in niche.

10.3 Snow patches under headwa11.

10.4 Cliff snow accumulations.

10.5 Snow or ice pocket?

10.6 Cliff snow pocket. Moraine?

4315

1 Small glacierette under $N$ side of Goat Mt. Ice-filled chutes. Moraine with sharp crest? 
APPENDIX 1.--Description of items in tables 1 and 2--Continued

1.1 Snow pocket. Tiny moraine extends below.

1.2 Snow patch under cliff.

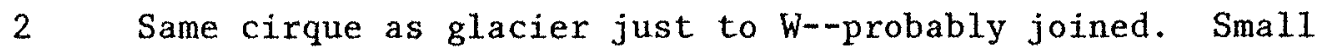
bergschrund(?), arcuate moraine, ice-filled chutes, steep front.

3 Small glacier tapers to make two ice-filled chutes. Narrow, arcuate moraine spills into lake. Probably connected to small glacier just to the $E$.

4 Glacierette? Upper ice in shady cleft, inflated tongue.

4.1 Moraine front, some snow or ice above.

5 Small glacier under high, steep, fluted headwall of Goat Mt. Moraine.

1 Tiny ice pocket. Lake below.

2 Tiny glacierette.

3 Tiny glacierette, snow-filled chute to near top of headwall. High, steep front spills against the glacier to the $W$.

4 Dying, mantle-loaded glacier. Ice-filled chutes, some small cracks, fine-textured surface ridges. Steep front spills into stocking Lake.

5 Dirty, rock-mantled, dyig glacierette(?). Ice-filled chute, looping ridges on narrowing front. Mostly rock glacier now?

5.1 Dirty ice at head of moraine below glacier 5 .

5.2 Ice pocket perched high in a saddle.

6 Cirque containing either two inflated rock glaciers or small, dying, ice-cored glaciers. Headwall ice, steep moraine fronts. 
APPENDIX 1.--Description of items in tables 1 and 2--Continued

7 Glacier located in steep, shady cirque. Two ice-filled chutes. Bergschrund cuts ice and rock mantle. Two fronts, steep talus spills into lake. Discharge from crest of moraine.

8 Rock glacier? Still inflated (ice-cored) morainal ridges. Discharge from base of low front. Some headwall ice remains.

9 Small glacierette. Longitudinal surface ridges. Steep front terminates in lake. Lower part rock glacier?

10 Small vanishing glacierette, probably mostly rock glacier. Snow in shade, longitudinal ridges on $W$ part. E part has looping ridges, ponds on surface. Two fronts.

10.1 Possible rock glacier, some snow in moat area. Adjoins glacier 10 .

11 Permanent ice-filled chutes. Surface mantled. Inflated by ice core, lobate body. Front terminates in triangular-shaped pond.

12 Glacier in cleft below chute. Inflated moraine merges against the glacier to its $E$ side. Both make a common front. Two colors or shades of rock on lower moraine.

12.1 Snow patch.

12.2 Cliff ice with short front terminating in lake.

13 Tiny ice pocket or cliff glacierette under Mt. Cotter. Inflated moraine.

14 Tiny glacierette on $\mathrm{NE}$ side of Mt. Clarence King. Front terminates in lake.

15 Small cliff glacier under shady headwall on NW side of Mt. Clarence King. Moraine, steep front.

15.1 Tiny ice pocket and moraine. 
APPENDIX 1.--Description of items in tables 1 and 2--Continued

16 Beautiful, small glacier under steep headwall. May have crevasses, inflated look. Steep front spills into the upper lake.

17 Cliff or headwall ice pocket. Moraine spill separated from glacier just to $\mathrm{E}$ by sharp, short rock divide.

17.1 Small snow or ice patch.

17.2 Tiny snow patches.

17.3 Ice pocket under steep headwa11.

17.4 Ice pocket under steep headwall. 4317

0.1 Moraines with fronts, few snow patches.

1 Steep ice, part terminates in lake.

2 Active rock glacier(?) under Forester Pass. Ice and snow in upper areas, inflated body, looping ridges.

3 Large dying glacier. Bergschrund is over $600 \mathrm{~m}$ wide, cuts through rock mantle. Fine-textured, rock-mantled, ridged surface. Pedestal rocks, front, with pond at base.

4 Dying glacier lies on $N$ side of Kings-Kern Divide, just $E$ of Gregory's Monument. Bergschrund over $650 \mathrm{~m}$ wide cuts rockmantled upper ice. Much rock cover, pedestal rocks(?). Rock glacier extension in lower parts, with many low loops, and low, steep front. Discharge at base.

5 Beautiful small glacier on NE side of Mt. Stanford. Small crevasse in upper area. Steep moraine front, spills into lakelet. Discharge from near crest of moraine. Small detached ice pocket to $W$ in same cirque also has small moraine. 
APPENDIX 1.--Description of items in tables 1 and 2--Continued

5.1 Snow patches.

5.2 Snow patch accumulation?

6 Small glacier. Trace of small bergschrund, much rock mantle, cracks in upper $W$ ice. Lobate moraine front.

7 Upper area is rock glacier with ice-filled, shady chutes; lower area rock mantle. Moraine front. Associated rock glacier hugs arete headwall shadow, many loops, probably some ice core. Front spills talus to basin floor.

7.1 Avalanche snow accumulation, always present. Very low altitude. Arcuate moraine.

7.2 Ice core appearance.

8 Dying glacier. Headwall ice dirty, pedestal rocks possibly in upper ice area, looping, inflated, rock-mantled central area, sagging lower areas. Low, sgging moraine front.

9 Ice pocket and ice-filled chute lie on Deerhorn Mt. Moraine, steep front. Appears solid.

10 Glacier, shady ice-filled chutes. Fairly large bergschrund, crevasses, rock mantle. Front terminates in lake.

11 Dying glacier, thinning out, probably mostly rock glacier. Permanent exposed ice only in upper, shady areas. Steep front. Discharge from base. "Lucy's Foot Pass Rock Glacier".

11.1 Snow under cliff.

11.2 Snow or ice under cliff? 
APPENDIX 1.--Description of items in tables 1 and 2--Continued

12 Small glacier(?) lies in a shady niche on $\mathrm{N}$ side of Mt. Jordan, above Lake Reflection. Trace of bergschrund. Inflated, rock mantled. Sharp arcuate or lobate front.

12.1 Snow or ice pocket.

13 Headwall ice accumulation on NW side of peak. Moraine?

14 Shallow ice lies in niche. Rock mantle on lower parts.

15 Glacierette on NE side of Thunder Mt. Appears healthy, Much snow nearly surrounds entire inflated lower area. Steep front.

16 Sma11, well-formed glacier lying in shady niche of a compound cirque. Bare ice, banded ice(?), pedestal rocks(?). Moraine front.

17 Small glacier in niche under steep headwall. Ice-filled chutes. Trace of bergschrund. Has stepped, arcuate ridged lobe, inflated, rock-mantled ower area with rock spilling over into lake.

18 Small cliff glacierette lies under peak. Shady, cracks, icefilled chute. Moraine front spills rock far below.

18.1 Snow or ice under cliff.

19 Small glacier at head of Ouzel Creek. Bergschrund. Forked discharge comes from top of front.

20 Mt. Brewer glacier or glacierette. Probably still active. Bergschrund, pedestal rocks. Sharp-crested moraine front. Another small ice pocket just to $N$ separated from Brewer Glacier by sharp, dike-like ridge.

20.1 Ice or snow associated with but separated from Brewer Glacier by small dike-like ridge. 
APPENDIX 1.--Description of items in tables 1 and 2--Continued

20.2 Snow or ice under headwall.

21 Northguard Glacierette, in shady cirque. High fluted headwall, bergschrund. Sharp-crested, sharply arcuate moraine. Front spills talus far below.

22 Glacierette (ice-filled chute?) with rock glacier extension spilling front into lake.

23 Cliff glacier with rock glacier extension (ice-filled chute?). Band of headwall ice extends westward to a point even with front. Much rock mantle, and inflated look. Moraine front.

0.3 Snow patches under headwall.

1 Table Mt. Glacier, many ice-filled chutes. Bergschrund over $300 \mathrm{~m}$ across, dirty ice, pedestal rocks, much rock mantle. Pond at low moraine front.

1.1 Ice-filled chutes, dirty small glacierette? Rock mantle and moraine front.

1.2

2 Cliff accumulation lies under shadowy headwall niche. Moraine.

2.1 Probably avalanche snow patch.

3 Ice lies under steep, shady cirque headwall. Tongue with few loops. Discharge from base of older, deflated front.

4 Cliff accumulation in cirque headwall. Moraine below.

5 Ice pocket lies under headwall of Triple Divide Peak.

5.1 Snow or ice accumulation under cliff. Small moraine.

5.2 Snow or ice accumulations under cliff. 
174 Inventory of Glaciers in the Sierra Nevada, California

APPENDIX 1.--Description of items in tables 1 and 2--Continued

5.3 Snow or ice accumulations under cliff.

4321

0.1 Cluster of snow or ice patches lying in niches and in cirque above Upper Lion Lake. Tiny moraine into lake.

0.2 Snow or ice in niche.

1 Under steep headwal1, barely separated from the main (West) Lilliput Glacier. Appears solid. Moraine.

2 Lilliput Glacier, lies under steep headwall. Bergschrund, suggests rough ice or pedestal rocks in lower area. Moraine.

3 Glacier under steep NW headwall of Mt. Stuart. Cracks, moraine. Glacier at low elevation for the latitude.

3.1 Tiny glacierette or ice pocket. Has a moraine front.

4 Tiny glacier or ice pocket lies perched on a ledge under steep headwall of Eagle Scout Peak. Cracks.

4.1 Snow patch probably permanent.

5 Cliff accumulation lies undex steep headwall. Small moraine-1ike accumulation.

5.1 Small ice pocket on Mt. Eisen.

5.2 Small ice pockets on Mt. Eisen. Moraine fronts.

5.3 Snow accumulation.

5.4 Lies under steep headwall.

5.5 Snowfield. Appears to have a few cracks and pedestal rocks.

6 Well-developed glacierette. Crevasses, arcuate end moraine with tiny ribbon of water descending from crest. 
APPENDIX 1.--Description of items in tables 1 and 2--Continued

4322

1

1.1 Ice pocket separated from the main glacierette under Mt. Florence. Has a few crevasses and a tiny moraine-like accumulation.

1 Ice pocket in cirque ESE of Shotgun Pass. Cracks or wrinkles. Lumpy moraine. Older moraine below.

1.1 Snow patch.

1.2 Snow patch. Moraine.

1.3 Snow patch.

1.4 Snow patch.

1.5 Lies under steep headwall.

2 Small cliff glacierette. Many parallel cracks. Sharp-crested moraine.

2.1

2.2 Little snow in headtall. Moraine of dark metamorphic rocks.

2.3 Tiny glacierette or ice pocket in niche.

2.4 Snow patch in niche.

2.5 Snow patch.

2.6 Dirty permanent snow or ice accumulation under cliff. Terminates in lake.

3 Crevasses in snowfield, pedestal rocks. Probably deep ice body.

4 Small, perched glacierette. Sharp moraine spills talus over snow ice body below.

5 Ice wall terminates in lake. 
APPENDIX 1.--Description of items in tables 1 and 2--Continued

5.1 Snow ice avalanche pockets that terminate on lake edge. Some crevasses or cracks seen.

4332

0.1 Avalanche snow terminating as ice wall in lake.

0.2 Small permanent snow. Some moraine.

1 Steep W wall ice, rock glacier? Some crevasses. High bold front.

1.1 Avalanche snow. Terminates as snow wall in lake.

2 Dying glacier, Small bergschrund, pedestal rocks, much rock mantle, crevasses. Big discharge from base and waterfall from crest.

3 Active glacier. Bergschrund, crevasses, pedestal rocks, discharge from crest. High talus front spills into lake below. May be southernmost active glacier in continental USA.

4 Same headwall as glacier $\|_{3}$. Small bergschrund, pedestal rocks(?), lower part rock-mantled. Double moraine fronts.

5 Red Kaweah Glacier. Perched on shelf under steep headwall, many cracks. Two moraine fronts (high), discharge from near crest of front.

6 Small glacier in chute. Crack. Sharp-crested moraine.

6.1 Ice pocket. Terminates in small lake.

7 Very steep cliff glacierette. Small headwall cracks or trace of bergschrund. Sharp-crested, V-shaped end moraine.

7.1 Several snow or ice patches, probable remnant of shallow glacierette. 
APPENDIX 1.--Description of items in tables 1 and 2--Continued

8 Glacier seen in 1938. Sharply-crested moraine, bold front, pedestal rocks. Tiny pond lies in back of moraine crest. Discharge from near moraine crest.

8.1 Snow ice field in same cirque with glacier 8 .

9 Sma11, well-formed glacier lies in cirque at head of Picket Creek. Bergschrund.

10 Glacier at head of Kern-Kaweah River. Bergschrund, banded glacial ice, pedestal rocks, some rock mantle. Pond lies on ice in back of sharp-crested moraine. Front spills into two ponds.

10.1 Ice area below glacier 10, lower part shares same moraine.

A detached ice pocket lies under cliff.

11 Glacierette undex cliff. Trace of bergschrund, pedestal rocks, Sharp-crested moraine. Appears tiny pond lies in back of crest.

11.1 Snow patch.

12 Avalanche catch basin. Tiny pond suggested at snout. Moraine?

1 Small glacier? Lies in narrow, steep, small, shady cirque. Crevasses. Sharp moraine front.

2 Terminates in lakelet.

3 Ice pockets in narrow niche along Kern Ridge. Rock-mantle lower parts. Sharp-crested fronts.

3.1 Kern Ridge ice pocket. Has small moraine front.

4 Cliff ice accumulation. Dirty, talus-covered parts. Ice-filled chutes above. Talus spills into pond below. 
APPENDIX 1.--Description of items in tables 1 and 2--Continued

5 Milestone Mt. Glacier. Bergschrund, crevasses, dirty ice, pedestal rocks. Lower part rock mantled. Sharp-crested moraine. Discharge in three places from base of front.

5.1 Permanent snow in eroded joint.

5.2 Snow.

6 Ice pockets below Midway Mt. Largest has moraine, upper one has tiny moraine. One body with two fronts.

6.1 Ice pocket. Has moraine front.

6.2 Snow accumulation.

6.3 Snow patches.

7 Table Mt. glacier. Trace of bergschrund, crevasses, pedestal rocks, dirty ice, usual rock mantle. Moraine crest spills talus to basin floor. Discharge from front.

7.1 Small ice pocket. Small moraine, dumps into lake.

8 Caltech Peak's tiny glacierette. Cracks. Small moraine spills talus into lakelet below.

8.1 Snowin an eroded joint or niche.

8.2 Snow (lower chute) in joint or niche.

8.3 Snow (upper chute) in joint or niche.

8.4 Snow avalanche accumulation?

9 Lake Tulamyo snow ring ("Dangerous Glacier"). High vertical wall of snow calves off into lake. Lake sometimes frozen through the entire season.

10 Remnant glacier in shady niche in cirque on Mt. Russel. High ice cliffs, cracks. Ice calves off into lake. 
APPENDIX 1.--Description of items in tables 1 and 2--Continued

11 Mt. Russel's NW sheet of snow-ice. Thin? Tiny pond lies on older deflated moraine below.

12 Remnant Mt. Hale glacier. Bergschrund, pedestal rocks(?), rock mantle over lower areas. Moraine front terminates in lakelet.

0.1 Avalanche snow accumulation. Sma11 moraine.

0.2 Snow in chutes.

0.3 Snow accumulation.

1 Headwall hugger. Crevasses in upper ice area. Moraine terminates in tiny lake.

2 Howell Glacier. Cracks in upper area. Moraine front.

4411

1 Glacierette.

1.1 Drift snowfield on slope.

2 Glacierette. Traces of crevasses in headwall area.

2.1 Snow ice pocket. Possible crack in upper dark area.

2.2 Snow avalanche accumulation in bottom of shallow cirque. 4412

0.1 Ice pocket or tiny glacierette. Possible crack on upper area. May show thin moraine.

0.2 Snowdrift on slope.

1 Glacierette(?) on N side of Leavitt Peak. Much dark rock mantle on ice. Front terminates in lakelet. Complex moraine.

2 Glacierette. Thin rock mantle in mid-part. Moraine front terminates in Dead Horse Lake. 
APPENDIX 1.--Description of items in tables 1 and 2--Continued

2.1 Snow patches and dirty ice pocket perched above and $\mathrm{W}$ of Deadhorse Lake.

3 Active rock glacier. Many loops, fronts. Terminates above Blue Canyon Lake.

3.1 Snow accumulation under steep slope.

4 Glacierette at head of cirque. Surface dirty. Moraine crest spills dark volcanic rocks onto glacial feature below.

5 Glacierette. Appears to have thin load of volcanic rock mantle. Moraine ridges, sharp front.

6 Tiny glacierette in cirque on $\mathrm{N}$ side of Kennedy Peak. Bold Moraine front.

6.1 Cluster of snow patches occupying clefts in rock.

6.2 Cluster of snow patches occupying clefts in rock.

7 Glacierette under volcanic headwall. Two shades of snow and ice. Fine-textured, dark end moraine.

7.1 Snow patch.

8 Snow ice pocket in volcanic cirque. Fine-textured moraine.

8.1 Snow pocket.

9 Glacierette(?)or ice pocket E side of Relief Peak. Several shades of snow. Dark volcanic rocks.

9.1 Snowfield.

9.2 Snowdrift lying in depression of volcanic-granitic contact.

9.3 Snow-filled, eroded joint in granite above Black Hawk Lake.

9.4 Snow accumulation in cleft. Small crevasses near top.

9.5 Snow-filled eroded joint in granite above Lewis Lakes.

9.6 Snow-filled eroded joint in granite above Lewis Lakes. 
APPENDIX 1.--Description of items in tables 1 and 2--Continued

9.7 Snowdrift lying in depression at volcanic-granitic contact.

9.8 Snow cornice on volcanic pendant atop granitic headwall.

9.9 Snow cornice on volcanic pendant atop granitic headwall.

9.10 Permanent snow or ice pocket. Several shades of snow lie under granitic headwall.

9.11 Snow accumulation under small granitic headwall.

9.12 Snowdrift $\mathrm{N}$ side of pass. Appears rather thick. 4431

0.1 Avalanche snow terminating in lake under $N$ side of Saurian Crest.

0.2 Snowfield, forming nivation cirque?

1 Main glacier on Forsyth Peak. Trace of bergschrund in shadowy headwall area, area of dirty ice and rock mantle. Long, tapering moraine.

2 Western glacier on Forsyth Peak. In shady cirque, several shades of snow to ice.

0.1 Snowdrift.

0.2 Snowfield, two shades of snow.

0.3 Snowfield, two shades of snow.

0.4 Avalanche snow accumulation fromsnow patches 0.5 and 0.6 below.

0.5 Snow patches under cirque headwall.

0.6 Snow patches under cirque headwall.

0.7 Snow lying on shelf under cliff.

1 Ice pocket in chute under $\operatorname{col}$ on Finger Peaks.

1.1 Snow in niche, $E$ part of Finger Peaks. 
APPENDIX 1.--Description of items in tables 1 and 2--Continued 4433

0.1 Snow accumulation on slope.

1 Mostly cliff huggers on $\mathrm{N}$ side of Whorl Mt. Moraine.

2 Glacierette under ice-filled chute on Whorl Mt. Moraine crest.

2.1 Snow patch in niche under steep slope.

2.2 Oval-shaped snow body lies at the head of valley trough between Stanton Peak and Gray Butte. Snow appears to be deep and forming a nivation cirque.

2.3 Elongated snow patch on gentle slope above patch 2.4 .

2.4 Elongated snow patch on gentle slope.

2.5 Snow patch on slope.

3 Small cirque glacier under Virginia Peak. Small lumpy moraine. High wall of snow terminates in lake.

3.1 Snow patch on gently-sloping plateau of Twin Peaks.

3.2 Snow patch on gently-sloping plateau of Twin Peaks.

4 Shallow glacierette? Lies in high sunny saddle.

5 Glacierette in cleft. Crack in headwall area. Lumpy moraine.

6 Snow ice under cliff.

7 Tiny cliff glacierette? Several shades of snow.

7.I Snow-ice niche under Shepherd Crest.

7.2 Ice pocket.

8 Glacierette in cleft. Moraine crest with high front.

9 Glacierette lies at NW end of Shepherds Crest. Lumpy moraine.

9.1 Snow patch above Upper McCabe Lake.

9.2 Snow patches above Middle McCabe Lake.

9.3 Snow pockets in cirque above Lower McCabe Lake. 
APPENDIX 1.--Description of items in tables 1 and 2--Continued

4434

NOTE: To date only small ice or snow patches are proved in this basin. Phot coverage not sufficient at present to properly map features.

0.1 Snow occupies shallow niche-like cirque above Roosevelt Lake.

0.2 Snow patches W. side of White Mt.

0.3 Snow patches above Skeleton Lake. Lower one terminates in lake.

0.4 Snow patches above Upper Young Lake.

0.5 Snow patches above Upper Young Lake.

4435

0.1 Ice pocket in nivation cirque. Feature noticed since 1945.

0.2 Snow or ice pocket lies above lake.

0.3 Snow or ice pocket.

0.4 Snow or ice pockets above Parker Pass Lake.

0.5 Snow or ice pocket.

0.6 Cluster of snow or ice pockets.

0.7 Cluster of snow or ice pockets SE of Helen Lake.

0.8 Snow accumulation wedged against lower part of E Lyell moraine. Several shades of snow.

1 Lyell Glacier, E lobe. Large glacier for this latitude. Bergschrund, crevasses, many pedestal rocks, rock-mantled snout area. Source of Tuolumne River.

2 Lyell Glacier, W Lobe. Large glacier for this latitude. Large central bergschrund, crevasses, several shades of snow, pedestal rocks, rock-mantled snout area. Ponds below well-developed, sharp-crested moraine. 
APPENDIX 1.--Description of items in tables 1 and 2--Continued

2.1 Many snow patches in the vicinity of Lyell Glaciers. Lie in joints, clefts, upon shelves, drift, etc.

2.2 Snowfield perched above $W$ lobe of Lyell Glacier.

3 Snow-filled, eroded joint in granitic rocks.

4 Shallow glacierette or permanent snow. Terminates in upper lakelet. Tiny moraine-like accumulation.

5 Mcclure glacier. Bergschrund about $500 \mathrm{~m}$ across, crevasses, banded ice, rock-mantled lower third. Ice to $\mathrm{W}$ connected at headwall.

5.1 Part of the McClure Glacier system. A humped-up moraine lies below this ice. The western part of the upper McClure Glacier spills steep ice into this part.

6 Shallow glacierette. Several shades of snow, small moraine.

6.1 Dirty snow accumulation.

7 Dirty, rock-mantled look. Terminates in pond.

8 Associated with glacier 7. Terminates in pond.

9 Headwall ice pocket.

10 Mostly cliff hugger. Separate snow tongue below terminates in oblong lake.

10.1 Snowfield. Terminates at upper end of a lake.

10.2 Snow patch on $N$ side of Amelia Earhart Peak.

10.3 Snow patch.

10.4 Snow patch E of Ireland Lake.

10.5 Snow patch.

10.6 Snow patch. 
APPENDIX 1.--Description of items in tables 1 and 2--Continued

10.7 Snow patch.

10.8 Snow patch $\mathrm{S}$ of Ireland Lake.

10.9 Snow patch.

10.10 Snow patch SE of Ireland Lake.

10.11 Snow patch SE of Ireland Lake.

10.12 Small snow patches at edge of Ireland Lake.

10.13 Snow patch.

10.14 Snow patch.

10.15 Snow patch.

10.16 Appears to be snow lying in joint.

10.17 Snow patch.

10.18 Snow patches lying in clefts, joints, and under walls.

10.19 Snow patches lying in clefts, joints, and under walls.

10.20 Snow patches lying in clefts, joints, and under walls. 4441

0.1 Snow patches in clefts.

$1 \quad$ Glacierette?

1.1 Snow under cliff.

2 Glacierette in cirque headwa11. Moraine.

3 Headwall glacierette. Moraine.

3.1 Snow patches.

3.2 Glacierette-like headwall ice. Two shades of snow.

3.3 Ice pocket or tiny glacierette. Crack near head. Tiny moraine.

3.4 Snow patch below moraine crest of ice pocket 3.3 above. 
APPENDIX 1.--Description of items in tables 1 and 2--Continued

4 Dying cirque glacier. Large pond has formed on ice core in back of moraine crest. Snow ring below point.

5 Rock glacier. Front overrides snow field.

5.1 Dirty snow terminating in tiny pond.

5.2 Ice pocket terminates in lake. Two shades of snow.

5.3 Ice pocket terminates in lake. Two shades of snow.

5.4 Ice pocket above ice pockets 5.1 and 5.3. Appears to have some moraine accumulation.

5.5 Headwall snow patches.

6 Dying cliff glacierette. Moraine front. More cliff ice just to W.

6.1 Dirty headwall ice under same cirque headwall as glacier.

7 Dying cliff glacierette. Sag in back of sharp crest.

7.1 Snow accumulation shelf.

7.2 Headwall snow patches.

7.3 Snow patches.

7.4 Snow patch under peak.

7.5 Snow patch under peak.

7.6 Snow patch under peak.

7.7 Snow patches lying in $\mathrm{S}$ facing cirque at the head of Hutching Creek.

8 Cliff ice on ledge under headwall. Dirty, several shades of snow. Moraine.

9 Dying glacier under Mt. Florence. Dirty ice, much rock cover, small cracks in headwall area. Big moraine front spills to floor.

9.1 Snow patches and accumulations in cirque to SW of Mt. Lyell.

9.2 Snow patches and accumulations in cirque to SW of Mt. Lye11. 
APPENDIX 1.--Description of items in tables 1 and 2--Continued

9.3 Snow patches and accumulations in cirque to SW of Mt. Lyell.

9.4 Snow patches and accumulations in cirque to SW of Mt. Lye11.

10 Small glacier. Several cracks, several shades of snow. Bold moraine front. Ponds at base.

10.1 Cluster of snow patches lying in cirque S of Mt. Lyell.

10.2 Snow patch in joint.

10.3 Snow in cleft.

10.4 Snow patch.

10.5 Ice/rock pocket. Has moraine.

10.6 Partially rock-covered snow pocket terminating in lake.

10.7 Snow accumulation in niche above lake.

10.8 Snow patch, result of avalanche chute.

11 Snowfield(?) perched high on slope.

11.1 Snow patch cluster. Some show several shades of snow.

11.2 Snow patch in cleft.

11.3 Headwall snow patch.

11.4 Snow patch.

11.5 Perched snow patch.

11.6 Snow patches and headwall ice pocket.

11.7 Snow accumulation in joint.

11.8 Ice pocket under steep, shady headwall of peak. Has crack.

12 Small cirque glacier. Cracks in upper ice, much rock and dirty ice. Bold front spills talus to basin floor.

12.1 Headwall ice pockets just $W$ of glacier 12 . Cracks in upper shady chute area, several shades of ice. Moraine. 
APPENDIX 1.--Description of items in tables 1 and 2 --Continued

12.2 Small ice pockets under steep, shady headwall just E of

12.3 Foerster Peak. Several shades of snow-ice. Several small

12.4 arcuate end moraine.

13 Forester Peak glacierette, associated with cluster of headwall ice pockets. Moraine with double arcuate crest and steep front.

14 Triple Divide Peak glacierette under cirque headwa11. Has two parts, each with its own arcuate end moraine with steep front.

14.1 Ice pocket lying in niche under same headwall area as Triple Divide Peak Glacier. Appears to have small moraine.

15 Ice pocket in niche in cirque $\mathrm{E}$ of Merced Peak.

15.1 Snow patches and tiny ice pockets lying under headwall ridge of Ottoway Peak.

15.2 Snowfield? Terminates in pond.

16 Tiny glacierette. Steep headwa11, moraines.

16.1 Ice pockets in niche, SE cirque of Gray Peak. Terminates in lake.

16.2 Ice pocket in joint-niche, part of NE cirque of Gray Peak.

16.3 Snow accumulation under headwall.

17 Under steep headwall. Moriane.

17.1 Headwall snow under $\mathrm{N}$ side Mt. Clark.

17.2 Headwall snow under $\mathrm{N}$ side Mt. Clark.

4442

1 J. Muir's first glacier seen in Sierra. Trace of bergschrund, cracks. Has moraine with sharp crest.

4451

0.1 Snow patches lying in Long Mt. cirque. 
APPENDIX 1.--Description of items in tables 1 and 2--Continued

0.2 Snow patch.

0.3 Snow patch.

0.4 Snow or ice pocket. Appears deep.

0.5 Snow patches below headwal1.

0.6 Snowfield terminating in lakelet.

1 Shallow glacierette,

1.1 Cliff ice. Several shades of snow. Rocky accumulation.

2 Shallow ice.

2.1 Snowfield perched above unmapped lake.

3 Tiny glacierette under small cirque headwall. Several shades of snow. Tiny crested moraine.

3.1 Snow accumulation.

3.2 Snow in narrow niche.

4 Two glaciers, one perched above the other, in S side of cirque.

Upper glacier lies under steep headwall and appears to overrun

lower glacier. Has sharp moraine. Lower glacier has several

shades of snow. Terminates in lake, cracks where calving off.

Moraine material.

4.1

4.2 Snow patches lying on shelves in cirque.

4.3 Snow ice pocket which extends nearly to top of headwall.

5 Glacierette in cirque. Tiny moraine.

5.1 Snow patches.

5.2 Snowdrifts and snow patches.

5.3 Snow patch.

5.4 Snow patch. 
APPENDIX 1.--Description of items in tables 1 and 2--Continued

6 Shallow snowfield? Rounded moraine.

7 Snowfield perched high in shallow cirque. Two other shallow bodies nearby.

7.1 Snowfield on top of gently sloping saddle.

7.2 Snowfield on top of gently sloping saddle.

7.3 Snowfield on top of gently sloping saddle.

7.4 Cluster of snow patches lying in clefts, joints, etc.

7.5 Snow patches.

8 Glacier in shady cirque NW side of Banner Peak. Small bergschrund, few crevasses, several shades of snow. Sharp-crested end moraine.

9 Main glacier on Mt. Ritter. Complex bergschrund system, crevasses, several shades of snow. Terminates at edge of Lake Catherine. Moraine material at crest of divide.

9.1 Cluster of snow patches and ice pockets lying in clefts, joints, etc.

\subsection{Snow patches.}

10 Snow pocket on shelf above lake.

10.1 Snow or ice pocket lying above glacier 10, under cliff.

10.2 Snow lying below moraine of large glacier. Terminates in lake.

10.3 Snow in cleft, terminates in lake.

10.4 Two snow patches lying under cliff, probably formed along a joint.

10.5 Snow patch.

11 Fairly large glacier. Bergschrund, banded and crevassed ice. Small moraine. 
APPENDIX 1.--Description of items in tables 1 and 2--Continued

11.1 Cluster of snow or ice pockets lying under headwall of a shallow cirque.

12 Niche in volcanic rocks.

12.1 Snow patches at base of shady cirque wall.

12.2 Snowdrifts.

12.3 Snow patch occupying an eroded joint.

12.4 Snow patches and ponds lying in back of old end moraine.

13 Glacierette at head of cirque. Steep, shady headwall, wrinkles or cracks. Sharp-crested moraine.

14 Glacierette(?) high in narrow cirque. Terminates in narrow end of lakelet.

14.1 Snow patch lying in shallow saddle.

14.2 Snow patches lying in niche of a cirque.

14.3 Ice pocket under same headwall as snow patch 14.4. Several shades of snow ice. Tiny moraine-like accumulation into Iron Lake.

14.4 Snow patch under headwal1. Several shades of snow, tiny cracks.

14.5 Snow or ice pocket under tiny cirque headwall. Terminates in a lakelet.

14.6 Snow patches. 4452

0.1 Snow accumulation.

0.2 Snow patches under headwall.

0.3 Snow lying in avalanche chutes (eroded joint).

0.4 Tiny glacierette-like feature with crevasses. Small moraine.

0.5 Snow patch under headwall. 
APPENDIX 1.--Description of items in tables 1 and 2--Continued

0.6 Snow or ice pocket lying on shelf under headwall. Supplied from snow chute occupying eroded joint.

1 Long, narrow glacierette in slot-like cirque. Two shades of snow. Some moraine material.

2 Glacierette in small cirque. Small crack near headwall. Moraine and snow terminate in unmapped lake.

2.1 Small ice pocket with snow-filled chute.

2.2 Snow patches.

2.3 Snow under headwa11.

2.4 Tiny ice pocket associated with snow patch 2.3. Small moraine?

2.5 Snow patch lying above small moraine material in cirque above Upper Beck Lake.

2.6 Snow pocket above small moraine in cirque above Upper Beck Lake.

2.7 Snow patch on steep talus slope.

2.8 Snow in niche or narrow cirque.

2.9 Snow in niche or narrow cirque.

3 Three main ice bodies. Ice-filled chutes, several cracks, several shades of snow. Undulating end moraine, spills over into Deadhorse Lake.

3.1 Snow ice pocket lying below moraine of glacier 3 , and against shady cliff. Several shades of snow.

4 Glacierette in chute. Cracks across headwall, several shades of snow. End moraine. Snow patches below moraine on both sides.

4.1 Snow patch under headwall.

5 Glacierette. Several shades of snow. Arcuate moraine accumulation. 
APPENDIX 1.--Description of items in tables 1 and 2--Continued

5.1 Snow chute.

6 Glacier above Cecil Lake. Bergschrund cracks, several shades of snow. Sharp-crested, sinuous end moraine terminating on slope above Cecil Lake.

6.1 Snow patch.

6.2 Snow patch.

6.3 Snow patches lying under cliff.

6.4 Snowdrift in saddle.

6.5 Snow patch below saddle.

7 Glacier in niche in volcanic rocks. Bergschrund. End moraine.

7.1 Snow ice pockets, some appearing deep, lying in clefts and along cirque sidewall.

7.2 Snowfield at head of narrow cirque.

8 Glacierette formed from snow spillover from the glacier above it. Several shades of snow. Moraine spills into Iceberg Lake.

9 Glacier under minoret. Bergschrund in $S$ part which rests deep in a niche, several shades of snow ice. Moraine.

10 Snow ice pocket under cliff.

10.1 Snow lying on shelf under cirque sidewall.

11 Glacier perched in high cirque. Traces of cracks, several shades of snow. Some moraine, spills over cliff.

12 Glacierette. Cracks in upper ice area. Some debris nearly covers a narrow central part. A small tongue descends from the $\mathrm{N}$ part.

13 Glacierette? Looks thin, several shades of snow. Small moraine. 
APPENDIX 1.--Description of items in tables 1 and 2--Continued

14 Glacierette in high shallow cirque. Several shades of snow.

Rounded end moraine.

15 Glacier $W$ of Lake Ediza. Narrow bergschrund, several shades of snow. Moraine.

15.1 Shallow snow covering moraine front of glacier 15 .

16 Tiny snow-covered glacierette or snowfield. Several shades of snow.

16.1 Snow accumulation in ice chute.

16.2 Ice patch, dependent and barely separated from glacier 17.

Lies above common end moraine of that glacier.

16.3 Snow below moraine.

17 Large glacier in cirque SE of Mt. Ritter. Bergschrund, crevasses, banded glacial ice, moraine. Includes lower ice patches. Lower two ice bodies with moraine almost disconnected from glacier.

18 Perched snowfield SSE side of Mt. Ritter.

18.1 Crevasses, bare ice and snow shades. Possibly buried ice.

19 High, perched glacier in $\mathrm{E}$ cirque between Banner Peak and Mt.

Ritter. Chute has many cracks in ice. Trace of bergschrund. Moraine.

19.1 Snow in cleft.

19.2 Snow lying in saddle of ridge crest.

20 Small cliff glacierette under steep, shady headwall. Cracks in snow. Moraine.

20.1 Snowfield lying in cleft under saddle.

21 Glacier in niche on Banner Peak. Bergschrund, crevasses, severa1 shades of snow. Arcuate moraine. 
APPENDIX 1.--Description of items in tables 1 and 2--Continued

21.1 Snow patch under cliff.

21.2 Snow patch under cliff.

22 Glacier on $\mathrm{N}$ side Banner Peak. Many cracks above and below wide bergschrund, several wide crevasses, several shades of snow. Sinuous, sharp-crested moraine.

22.1 Snow accumulation from glacier 22 .

22.2 Snow in cleft.

23 Shallow glacierette. Two parts barely connected, trace of bergschrund. Tiny moraine.

23.1 Snow accumulation in cleft below saddle.

23.2 Snow accumulation in saddle.

23.3 Snow patch.

23.4 Snow patch.

23.5 Ice pocket with long, slender snow-filled chute.

24 Cliff glacier on two levels. Small moraine.

24.1 Snow in cleft.

24.2 Snow accumulation. Receives snow-rock spillover from glacier $\$ 24$.

24.3 Snow patches under headwall.

24.4 Snow accumulation in eroded joint?

4453

1 Glacierette with dirty ice and snow. Wide, ice-filled chute, pedestal rock(?), cracks at base of headwall. Long tapering snout with low, step front.

1.1 Snow patch in niche. 
APPENDIX 1.--Description of items in tables 1 and 2--Continued

2 Glacierette on $\mathrm{N}$ side of peak. Nearly squared off front.

Discharge from base.

3 Glacier with dirty ice and snow, several ice-filled chutes, main

chute reaches to top of crest. Few cracks, pedestal rocks.

Glacier has two snouts with steep fronts and the $W$ snout

terminates in Franklin Lake.

4 Glacierette under shady cirque headwall. Cracks, pedestal rocks.

Sharply-crested, pointed arcuate moraine, much deflated moraine below.

4.1 Snow ice accumulation near ridge crest. Nivation cirque?

4.2 Ice pocket in niche.

4.3 Ice pocket in niche.

4.4 Dirty banded snow patch.

5 Cornice and ice-filled chute supply glacierette. Cracks, several shades of snow and ice. Moraine.

6 Tiny glacierette hugging headwall. Small moraine.

7 Small cirque glacierette. Cracks. Moraine narrows at terminus.

8 Izaak Walton Glacier. Cirque glacier. Bergschrund, crevasses, pedestal rocks. Discharge from crest of hig moraine.

9 Izaak Walton W. Glacier. Bergschrund, cracks near headwall. Moraine crest.

10 Glacierette, cracks near headwall. Moraine crest.

10.1 Snow or ice pocket. Tiny moraine?

10.2 Ice or snow accumulation under the north headwall of Graveyard Peak. Small moraine.

10.3 Small snow accumulation lies under headwall. Possible tiny moraine. 
APPENDIX 1.--Description of items in tables 1 and 2--Continued

10.4 Snow under chute. Tiny moraines.

11 Cliff snow accumulation or ice pockets under steep headwall. Two small moraine snouts.

12 Snow or ice pocket, may be small glacierette. Several chutes, inflated body crest. Tall front spills into narrow pond below.

12.1 Ice pocket, inflated look in lower rock-mantled area. Sharp crest and high front.

0.1 Snow or ice pocket. Tiny moraine?

0.2 Snow accumulation. Lumpy deflated moraine below.

1 Glacierette in narrow cirque on $\mathrm{N}$ side of Mt. Hopkins. Ice-filled chute, cracks, mantle, tongue-like snout.

2 Tiny glacierette. Low, sharp-crested moraine.

2.1 Small, dirty ice pockets. Low moraines below.

3 Ice pocket in cleft above Neelle Lake. Moraine.

3.1 Snow patch in joint or cleft.

4 Lies on $N$ side of Mt. Mills. Bergschrund cuts ice-filled chutes, banded glacial ice, cracks, pedestal rocks. Rock-mantled snout with arcuate looping ridges. Steep front. Pond on surface. Two discharge streams from base of front.

5 Mt. Mills' NW glacier to $W$ of main glacier. Bergschrund. Sharp-crested moraine.

6 Ice pocket in small shady cirque, SSW of Upper Snow Lake. Several shades of snow.

7 Dying glacierette, occupies steep shady cirque. Much rock-mantle, steep front. 
APPENDIX 1.--Description of items in tables 1 and 2--Continued

8 Glacierette in cirque. Cracks. Lumpy moraine.

8.1 Snow patch accumulations under steep slope.

9 Glacier with bergschrund? Much inflated moraine with steep front.

10 Sma11, dying, rock-mantled glacierette in cirque on NW side of Mt. Abbot. Long curving rock glacier tongue. Shady ice in headwa11. Discharge from base of steep front.

10.1 Snow patches.

11 Above Upper Mills Creek Lake. Large bergschrund; pedestal rocks, rock-mantled, low front.

12 Occupies cirque on NW side of Mt. Gabb. Head of Mills Creek. Pedestal rocks; small bergschrund; mantle; high, prominent front. Discharge from crest.

12.1 Possible bergschrund, dirty ice behind sharply-crested, steep-fronted moraine.

12.2 Snow patch accumulations lie under headwall cliff.

12.3 Ice pocket with small front terminates into lakelet below.

Partial snow ring in shallow moat.

13 Glacierette above Mist Lake. Bergschrund or cracks; dirty, rock-mantled mid-section. Sinuous, sharp-crested moraine crest. High, steep front.

13.1 Two ice pockets behind sharply-crested moraines.

14 Small glacierette occupies cirque on E side of Recess Peak. Sharp-crested moraine front. Pond at base.

15 Ice pocket under steep wall NE side of Recess Peak. Same cirque as glacier to $\mathrm{E}$. 
APPENDIX 1.--Description of items in tables 1 and 2--Continued

16 Cliff glacierette at head of First Recess. Possible cracks near headwall. Sharp-crested moraine.

16.1 Cliff ice pocket with dirty ice and possible cracks near the headwall. Complex moraine front.

17 Cliff-hugging ice under NW side of peak. Cracks. Dirty, rock-mantled ice with crack near headwall.

0.1 Snow patches perched at head of fluted chutes. Snow patch below.

0.2 Cliff or headwall ice pockets behind small moraine. Crack at head of largest ice pocket.

0.3 Snow ice in chute. Terminates as snow wall in lake.

0.4 Ice pockets behind lobate front terminating in upper Lake Italy.

0.6 Shallow snow or ice accumulation on slope.

0.7 Rocky ice pocket with inflated talus and front terminating in Jumble Lake.

0.8 Snow accumulation under steep headwall.

0.9 Snow patches under headwall.

0.10 Snow patches.

0.11 Ice pocket behind small moraine front.

1.11 Ice pocket in cleft above Upper Seven Gables Lake. Tiny, lumpy, moraine-1ike accumulation.

2 Small cliff glacierette in Seven Gables cirque. Associated cliff ice accumulation extends west for $600 \mathrm{~m}$. Moraine with steep front.

2.1 Headwall hugging cliff ice. Cracks near headwall.

2.2 Snow or ice accumulation in niches.

2.3 Snow or ice accumulation in niches. 
APPENDIX 1.--Description of items in tables 1 and 2--Continued

2.4 Snow or ice accumulation occupying eroded joints.

2.5 Snow or ice accumulation under steep headwall.

2.6 Ice pocket under steep headwall. Possibly tiny glacierette with moraine crest and front. Snow-filled chutes.

1 Ice pocket in cleft on $\mathrm{N}$ side of Gemini Peak. Snow rings. Lumpy, fronted moraine spills into the narrow lakelet below.

1.1 Tiny remnant glacierette hugging steep headwall behind long sharply-crested moraine. Crack in headwall ice.

1.2 Snow patches under steep headwall.

2 Small glacierette in cleft on $\mathrm{N}$ side of Royce Peak. Cracks, pedestal rocks(?). Rock mantle, front spills into Royce Lake.

2.1. Snow accumulation undex headwall.

2.2 Snow in joints under col.

3 Tiny glacierette or ice pocket. Cracks, sharp-crested moraine spills front talus into Upper Royce Lake.

3.1 Ice pocket.

3.2 Snow patch in possible eroded joint.

3.3 Snow streak in joint.

3.4 Snow lies in a saddle perched high on S side of Four Gables.

3.5 Snow under chutes $\mathrm{N}$ base of peak. Tiny moraine.

4 Ice pocket or tiny glacierette lies just NE of the Keyhold Glacier. Rocky mantle, pond on surface.

5 Keyhole Glacier, lies on N side of "The Keyhole". Banded ice, steep, some pedestal rocks.

5.1 Snow patch below Keyhole Glacier. 
APPENDIX 1.--Description of items in tables 1 and 2--Continued

5.2 Snow or ice pocket. Small moraine.

5.3 Snow patches at head of Muriel Lake.

5.4 Ice pocket. Moraine.

6 Ice in chutes. Small fronts, inflated.

6.1 Ice in chute.

7 Geothe Glacier. Occupies large cirque on $N$ side of Mt. Goethe. Many spectacular, inclined, ice-filled chutes cut a huge bergschrund. Crevasses, many pedestal rocks. Much rock mantle, looping ridges, surface ponds, high, steep front.

8 Thin bergschrund cuts ice-filled chute. Steep, pedestal rocks, high wall of vertical ice, crevasses. Bergs calve into water.

8.1 Snow patch in lower $\mathrm{E}$ moat of glacier 9.

8.2 Snow patch E side of glacier 9.

9 Small, narrow, step glacier S of Paine Lake on the Glacier Divide. Small bergschrund and cracks cut ice-filled chute, pedestal rocks. Sharp crest, mantle, steep front spills into the lake.

10 Glacier high on Glacier Divide above Paine Lake, occupies perched cirque. Cracks cut ice-filled chute. Rocky mantle, pond. Very sharp crest. Discharge from near crest of moraine.

11 Located on Glacier Divide above Packsaddle Lake. Small bergschrund cuts ice-filled chutes. Rock mantle, pedestal rocks. Sharp-crested, sinuous moraine. Talus spill forms cone below.

12 Thinly-proportioned glacier occupies a niche on Glacier Divide, SSW of Packsaddle Lake. Two levels of bergschrund cracks, rock mantle, pedestal rocks. Sharp crest spills talus to basin below. 
APPENDIX 1.--Description of items in tables 1 and 2--Continued

13 Occupies cirque on Glacier Divide, SSW of Packsaddle Lake. Wide bergschrund, banded ice, pedestal rocks, usual mantle. Sharp front butts against lower side of the glacier to the $\mathrm{E}$.

14 Ice pocket or tiny glacierette. Has lumpy moraine accumulation.

14.1 Snow patch accumlations under cliff. Associated with glacier 非14.

15 Bergschrund cuts several ice-filled shutes, banded ice, pedestal rocks, steep headwall. Two main snouts. Talus to basin floor.

15.1 Ice pocket just $W$ of glacier 15. Connected at the headwall, but have separate snouts. Trace of a bergschrund, cracks in upper dirty ice, much rock mantle. Moraine with steep front.

16 Western-most glacier above Lobe Lakes. Headwa11 cracks, horseshow-shaped moraine.

17 Cirque glacier above Honeymoon Lake. Trace of bergschrund, cracks, snow-filled chute, pedestal rocks. Sinuous moraine crest.

18 Long, narrow glacier in cirque above Ramona Lake. Bergschrund cuts ice-filled chute area. Ponds with icebergs form on surface, banded ice, pedestal rocks. Long, ice-cored, looping rock-mantled snout. Narrow steep front.

18.1 Cliff-hugging snow or ice patches.

19 Remnant Glacier. Sma11, lumpy accumulation occupies only part of cirque headwall.

19.1 Small ice pockets in cliff.

19.2 Ice pocket in narrow cirque.

0.1 Snow accumulations under fluted cliff. Talus accumulation.

0.2 Snow patches in cirque. 
APPENDIX 1.--Description of items in tables 1 and 2--Continued

0.3 Ice pocket or tiny glacierette in same cirque as snow patch 0.2 . Three shades of snow to ice. Rounded moraine surrounds entire feature.

0.4 Snow patches lie at base of cliff, onto edge of large lake $S$ of the Keyhole.

0.5 Snow accumulations under cliff high above large lake just $W$ of Mt. Lamarck.

0.6 Snow patch lies under cliff just $W$ of feature 0.6 . Several cracks seen.

0.7 Snow patches under chute and cliff. Moraine front which terminates in lake $W$ of Mt. Lamarck.

0.8 Long snow accumulations lie in depressions and saddles. Lower one appears fairly deep. Several shades of snow.

1 Glacier has a huge, ice-filled chute cut by a bergschrund. Banded ice. Sharp-crested moraine. Both parts of Darwin Glacier may be barely connected interstitial ice.

2 Main lobe of Darwin Glacier. High, ice-filled chute, large bergschrund, well-banded ice, pedestal rocks. Discharge from crest of sharp-crested arcuate moraine. Talus spills to basin floor.

3 Occupies cirque on $\mathrm{N}$ side of Mt. Mendel. Wide open bergschrund cuts a large ice-filled chute. Banded ice, pedestal rocks, rock mantle. Discharge from crest of tongue-like moraine.

3.1 Snow accumulation. Tiny moraine. 
APPENDIX 1.--Description of items in tables 1 and 2--Continued

3.2 Snow streaks in joint.

3.3 Snow patches. Some moraine material.

3.4 Snow accumulation.

4 Glacierette on SW side of Mt. Wallace. Snout terminates in lake. Inflated, steep front. Nearby ice-filled chute.

4.1 Snow-ice part of glacier 4 .

4.2 Snow in narrow chute.

5 Well-formed glacier on Mt. Fiske. Wide bergschrund, banded ice, pedestal rocks. Arcuate-shaped moraine front spills talus into the side of lake.

5.1 Snow patch at moraine front area of glacier.

5.2 Snow patches under cliff.

5.3 Snow patches in cirque just $\mathrm{E}$ of glacier 6.

6 Bergschrund cuts ice-filled chutes. Steep, bare ice, pedestal rocks. Arcuate front terminates in the lake below. Detached snow body just to the $E$.

6.1 Tiny ice pocket under Mt. Huxley. Cracks in upper ice, partial snow ring in moat. Sharp moraine crest.

7 Ice-filled chute on $\mathrm{N}$ side of Mt. Huxley. Thick ice-cored, inflated talus front, lobate. Moraine.

\subsection{Snow patches.}

8 Glacier in small niche NW side of Mt. Solomons. Sharp-crested moraine.

8.1 Snow streaks or patches.

8.2 Upper ice pocket above Wanda Lake. 
APPENDIX 1.--Description of items in tables 1 and 2--Continued

9 Shallow ice pocket and some snow patches lie in shallow cirque just S of Wanda Lake. Two separate small fronts. Much rock mantle over dirty, gray ice and snow.

9.1 Snow in clefts just $E$ of Goddard Glacier.

9.2 Snow patch in cirque.

10 Dirty, rock-covered ice pocket and ice chute on $\mathrm{NE}$ side of Mt. McGee. Detached from the main glacier. Sharp-crested moraine.

11 Mt. McGee Glacier. Large bergschrund cuts ice-filled chute. Crevasses, banded ice in lower bare ice area. Small pond in depression between the two snouts. Sinuous sharp-crested moraine spills talus to the basin floor.

12 Mt. McGee W Glacier, Cracks in upper headwall. Fine-textured dark rock mantle.

13 Peter Peak Glacier. Dying glacier(?) occupies shady cirque and shady chutes. Fine-textured rock mantle. Some cracks in ice, ice-filled chutes(?). Squared-off steep front spills talus into the pont at base. Older, deflated moraines below.

13.1 Small ice or snow pocket. Tiny moraine?

14 Glacierette in niche, upper ice in shadow. Fine-textured rocks. Long, steep front.

15 Small headwall glacierette. Several shades of snow. Fine-textured front merges with the ice pocket to the W.

16 Ice pocket under shady chute. Cracks in ice moraine.

16.1 Ice pocket in small shady cleft. Cracks in upper ice, some fine-textured rock mantles the ice or snow. Moraine crest, long front terminates in lake below. 
APPENDIX 1.--Description of items in tables 1 and 2--Continued 4458

1 Goddard Glacier. Main glacier on N side of Goddard Divide. Huge, undulating bergschrund cuts ice-filled chutes, banded ice, crevasses, pedestal rocks. Sinuous, sharp-crested moraine. Many tiny discharge streams issue from the base of the moraine.

1.1 Snow accumulations below moraine of Goddard Glacier.

1.2 Perched snow above Goddard Glacier.

2 Fairly large glacier S of Upper Dans Lake. Bergschrund cuts ice-filled chutes, banded ice, pedestal rocks, sharp-crested moraine of darker, fine-textured rocks.

3 Glacierette(?) occupies niche on E side of peak. Tiny, moraine-like accumulation.

3.1 Snow in niche.

3.2 Snow or ice pocket in narrow cirque.

4 Tiny glacierette or ice pocket. Lies in niche on $E$ side of peak. Sma11 moraine.

5 Glacierette heads in summit cornice. Dirty, fine-textured mantle. Sharp-crested moraine spills tapering talus nearly to edge of lake below.

6 Glacier on NW side of Mt. Goddard. Wide bergschrund cuts ice-filled chutes, crevasses, banded ice, pedestal rocks, dark mantle, pond on surface. Many low, arcuate morainal ridges. Low, steep front.

6.1 Snow streaks and talus cone in eroded slot.

6.2 Snow accumulation in cleft above Martha Lake. Cracks, vertical wall of snow or ice, approximately $6 \mathrm{~m}$. Terminates in lake.

6.3 Tiny snow accumulation. Sma11 moraine. 
APPENDIX 1.--Description of items in tables 1 and 2--Continued

6.4 Snow patch in niche due $S$ of Martha Lake.

6.5 Snow or ice pocket in small cirque under Mt. Reinstein.

6.6 Snow patch.

6.7 Snow patch.

6.8 Small ice pockets(?) lie under steep headwall.

6.9 Snow in niche near Hell For Sure Pass. Appears to have small accumulation below.

6.10 Snow patch.

$7 \quad$ Cliff ice pockets.

8 Small, stubby glacierette in cirque under peak. Lumpy, inflated body.

8.1 Tiny headwall or cliff ice pocket under steep headwall. May be tiny glacierette with moraine.

0.1 Snow patches lying on slope in clefts and against joints on NW slope of Jacks Peak.

0.2 Snow patches under cliff.

0.3 Snow patches, probably shallow, NE side of Crystal Range above Clyde Lake.

0.4 Snow patches lying on slope, joints, and clefts.

0.5 Snow patches in clefts above Lake Doris.

0.6 Headwall snow or ice pocket. Small headwall crack? Moraine has snow patch and possibly small trees.

0.7 Snow or ice pocket under same headwall as snow pocket 0.6 .

0.8 Snow pockets under same headwall as snow pockets 0.6 and 0.7 .

0.9 Snow patch lying in shallow cirque above Leland Lakes. 
APPENDIX 1.--Description of items in tables 1 and 2--Continued 4561

0.1 Snow patches under cirque wall of Mt. Price.

1 Glacierette near top of narrow cirque on $W$ side of Pyramid Peak.

0.1 Snow or ice pocket in cleft on side of Pyramid Peak. Two shades of snow and small moraine accumulation.

0.2 Snowfield in shallow cirque between pyramid Peak and Peak 9686. Older shade of snow with fresh. Moraine accumulation.

0.3 Snow lying in cleft above a joint.

0.4 Snow in shady cleft.

0.5 Snow patch lying under steep headwall of the Crystal Range.

0.6 Small ice pockets above pond under Crystal Range headwall. Shallow arcuate end moraine.

0.7 Small ice under same steep, shady headwall as ice pocket 0.6 .

0.8 headwall ice pocket perched high in cleft under shady wall. Rock accumulation just below ice or snow lies below.

0.9

0.10 Upper part of snowfield, in cirque.

1 Few headwall cracks. Moraine lies under steep, shady headwall.

2 Lies under steep headwall.

2.1 Snow patch probably connected to glacier 2 in shadowy headwall area.

2.2 Snow patch occupies joint and spreads out into ledges.

2.3 Headwall snow or ice pockets lying under same shady, steep headwall as snow patches 2.1 and 2.2 . 
APPENDIX 1.--Description of items in tables 1 and 2--Continued

4563

0.1

1 Glacierette under steep headwall in highest part of cirque.

Trace of bergschrund-like crack in shadowy area moraine.

2 Fairly deep glacier $N$ side of a saddle.

2.1 Cluster of snow patches.

2.2 Drift snow in niche.

2.3 Snow in avalanche chute.

2.4 Small cirque snow or ice pocket. Has a small arcuate moraine of Neoglacial age.

2.5 Snow in niche.

2.6 Drift snow $N$ side of saddle. 
210 Inventory of Glaciers in the Sierra Nevada, California

APPENDIX 2.--Glacier inventory numbering systems

U.S. Geological Survey

(Table 1A)

\begin{tabular}{|c|c|c|c|c|}
\hline Major basin & River & $\begin{array}{l}\text { Basin } \\
\text { number }\end{array}$ & $\begin{array}{l}\text { Glaciex } \\
\text { number }\end{array}$ & $\begin{array}{c}\text { ICSI } \\
\text { identification } \\
\text { number }\end{array}$ \\
\hline \multirow[t]{7}{*}{ North Lahontan } & East Carson & $\begin{array}{l}4111 \\
4111 \\
4111 \\
4111 \\
4112\end{array}$ & $\begin{array}{l}1 \\
2 \\
3 \\
4 \\
1\end{array}$ & $\begin{array}{l}\text { US2L11101004 } \\
\text { US2L11102004 } \\
\text { US2L11103004 } \\
\text { US2L11104004 } \\
\text { US2L11201004 }\end{array}$ \\
\hline & West Walker & $\begin{array}{l}4121 \\
4121 \\
4121 \\
4121 \\
4121\end{array}$ & $\begin{array}{l}1 \\
2 \\
3 \\
4 \\
5\end{array}$ & $\begin{array}{l}\text { US2L12101004 } \\
\text { US2L12102004 } \\
\text { US2L12103004 } \\
\text { US2L12104004 } \\
\text { US2L12105004 }\end{array}$ \\
\hline & & $\begin{array}{l}4121 \\
4121 \\
4122 \\
4122 \\
4122\end{array}$ & $\begin{array}{l}6 \\
7 \\
1 \\
2 \\
3\end{array}$ & $\begin{array}{l}\text { US2L12106004 } \\
\text { US2L12107004 } \\
\text { US2L12201004 } \\
\text { US2L12202004 } \\
\text { US2L12203004 }\end{array}$ \\
\hline & East Walker & $\begin{array}{l}4131 \\
4131 \\
4131 \\
4131 \\
4132\end{array}$ & $\begin{array}{l}1 \\
2 \\
3 \\
4 \\
1\end{array}$ & $\begin{array}{l}\text { US2L13101004 } \\
\text { US2L13102004 } \\
\text { US2L13103004 } \\
\text { US2L } 13104004 \\
\text { US2L13201004 }\end{array}$ \\
\hline & & $\begin{array}{l}4132 \\
4132 \\
4132 \\
4132 \\
4132\end{array}$ & $\begin{array}{l}2 \\
3 \\
4 \\
5 \\
6\end{array}$ & $\begin{array}{l}\text { US2L13202004 } \\
\text { US2L13203004 } \\
\text { US2L13204004 } \\
\text { US2L13205004 } \\
\text { US2L13206004 }\end{array}$ \\
\hline & & $\begin{array}{l}4132 \\
4132 \\
4132 \\
4132 \\
4132\end{array}$ & $\begin{array}{r}7 \\
8 \\
9 \\
10 \\
11\end{array}$ & $\begin{array}{l}\text { US2L13207004 } \\
\text { US2L13208004 } \\
\text { US2L13209004 } \\
\text { US2L13210004 } \\
\text { US2L13211004 }\end{array}$ \\
\hline & & $\begin{array}{l}4132 \\
4132 \\
4133\end{array}$ & $\begin{array}{r}12 \\
13 \\
1\end{array}$ & $\begin{array}{l}\text { US2L13212004 } \\
\text { US2L13213004 } \\
\text { US2L13301004 }\end{array}$ \\
\hline South Lahontan & Owens & $\begin{array}{l}4211 \\
4211 \\
4211 \\
4211 \\
4211\end{array}$ & $\begin{array}{l}1 \\
2 \\
3 \\
4 \\
5\end{array}$ & $\begin{array}{l}\text { US2L21101004 } \\
\text { US2L21102004 } \\
\text { US2L21103004 } \\
\text { US2L21104004 } \\
\text { US2L21105004 }\end{array}$ \\
\hline
\end{tabular}


APPENDIX 2.--Glacier inventory numbering systems--Continued

U.S. Geological Survey (Table IA)

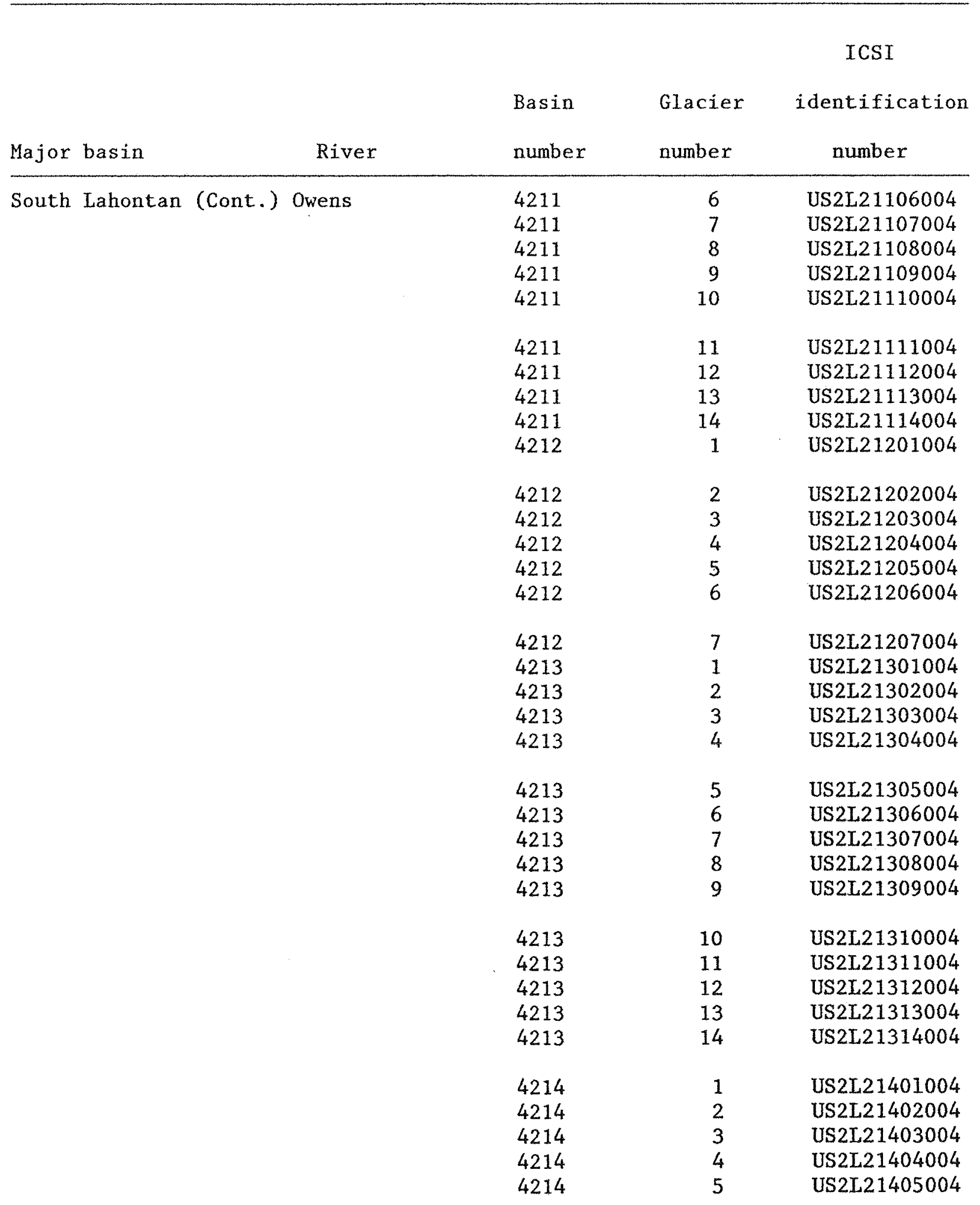


212 Inventory of Glaciers in the Sierra Nevada, California

APPENDIX 2.--Glacier inventory numbering systems--Contiued

U.S. Geological Survey

(Table 1A)

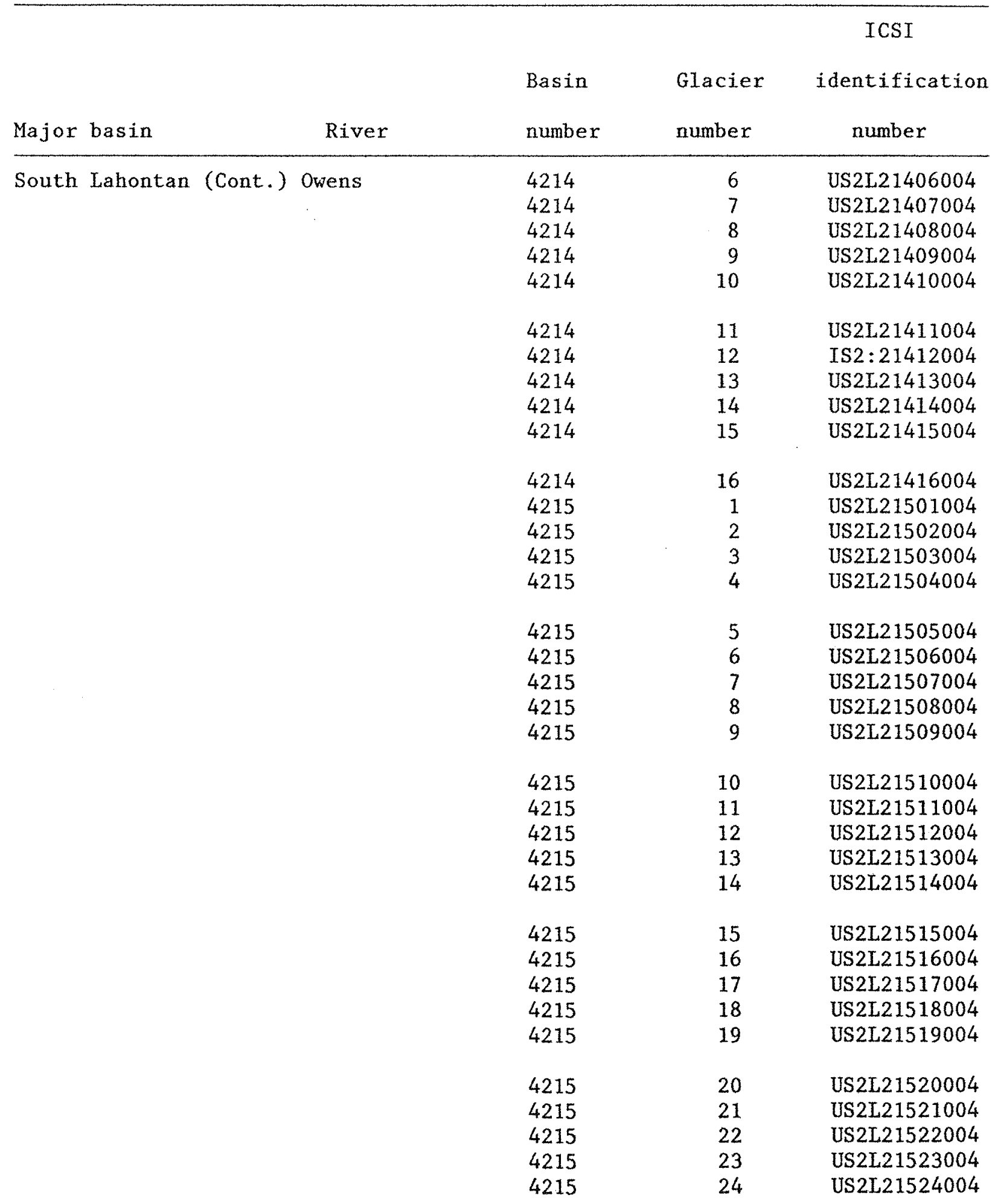


APPENDIX 2.--Glacier inventory numbering systems--Continued

U.S. Geological Survey

(Table 1A)

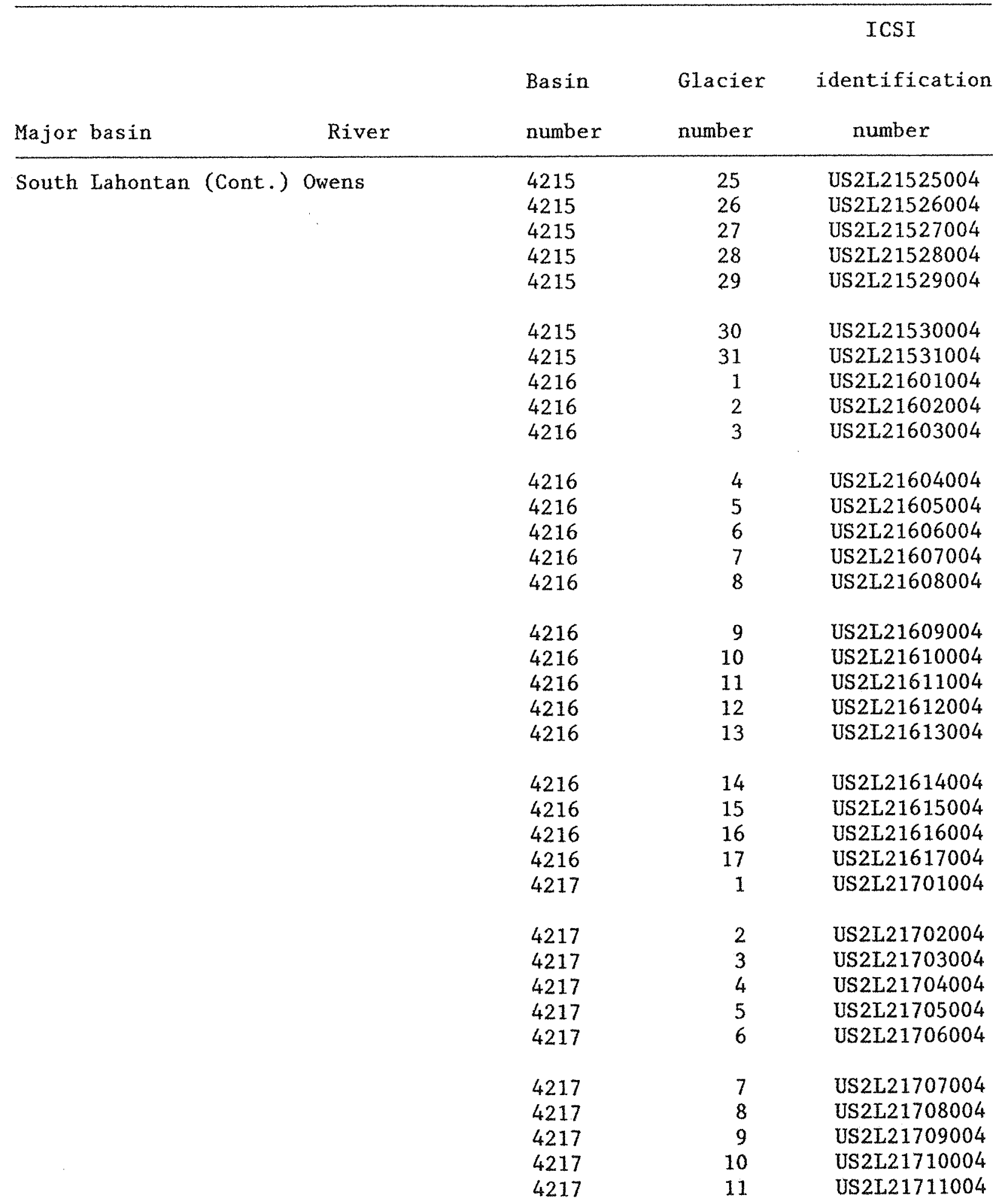


214 Inventory of Glaciers in the Sierra Nevada, California

APPENDIX 2.--Glacier inventory numbering systems--Continued

U.S. Geological Survey

(Table 1A)

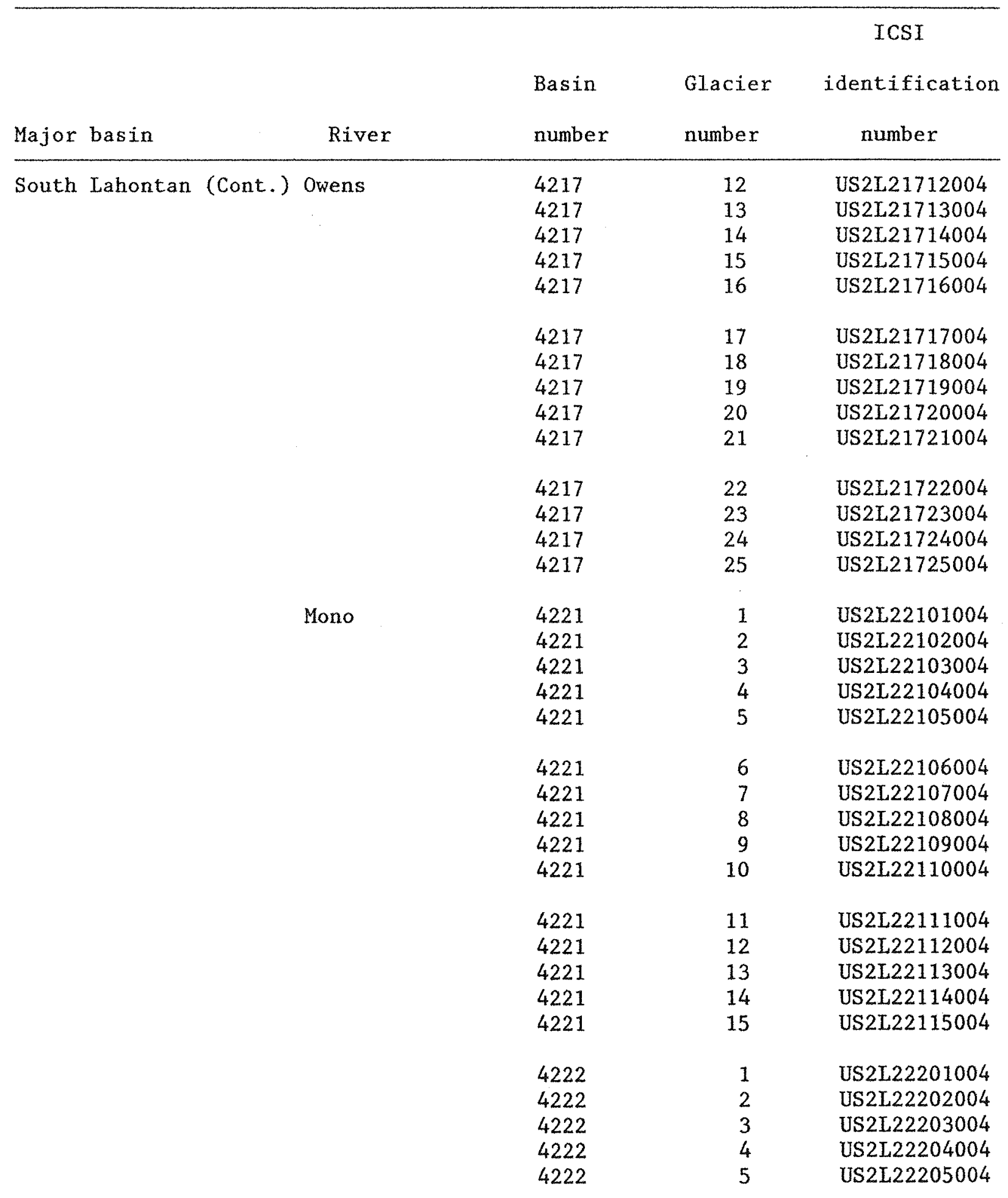


APPENDIX 2.--Glacier inventory numbering systems--Continued

U.S. Geological Survey

(Table 1A)

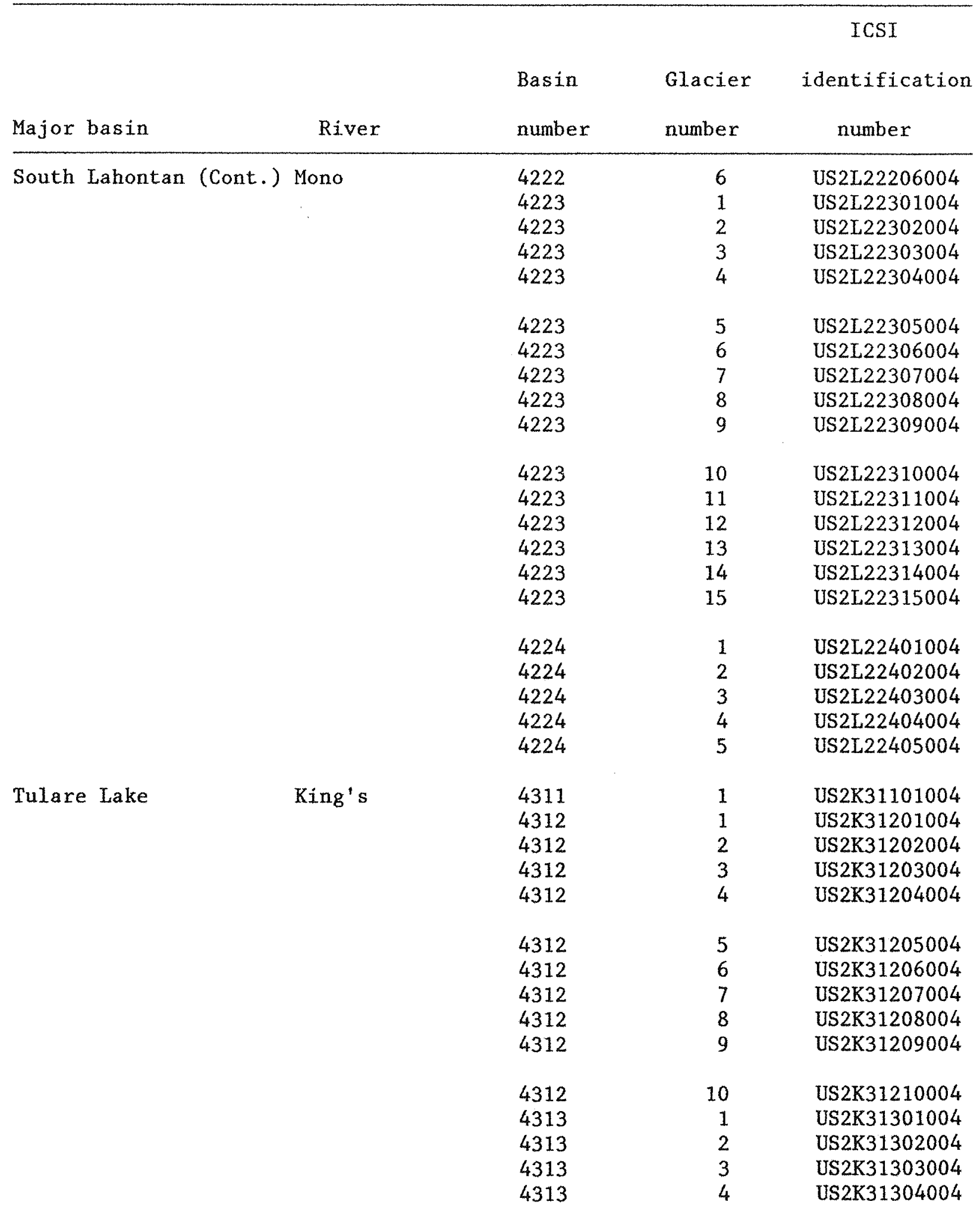


U.S. Geological Survey

(Table 1A)

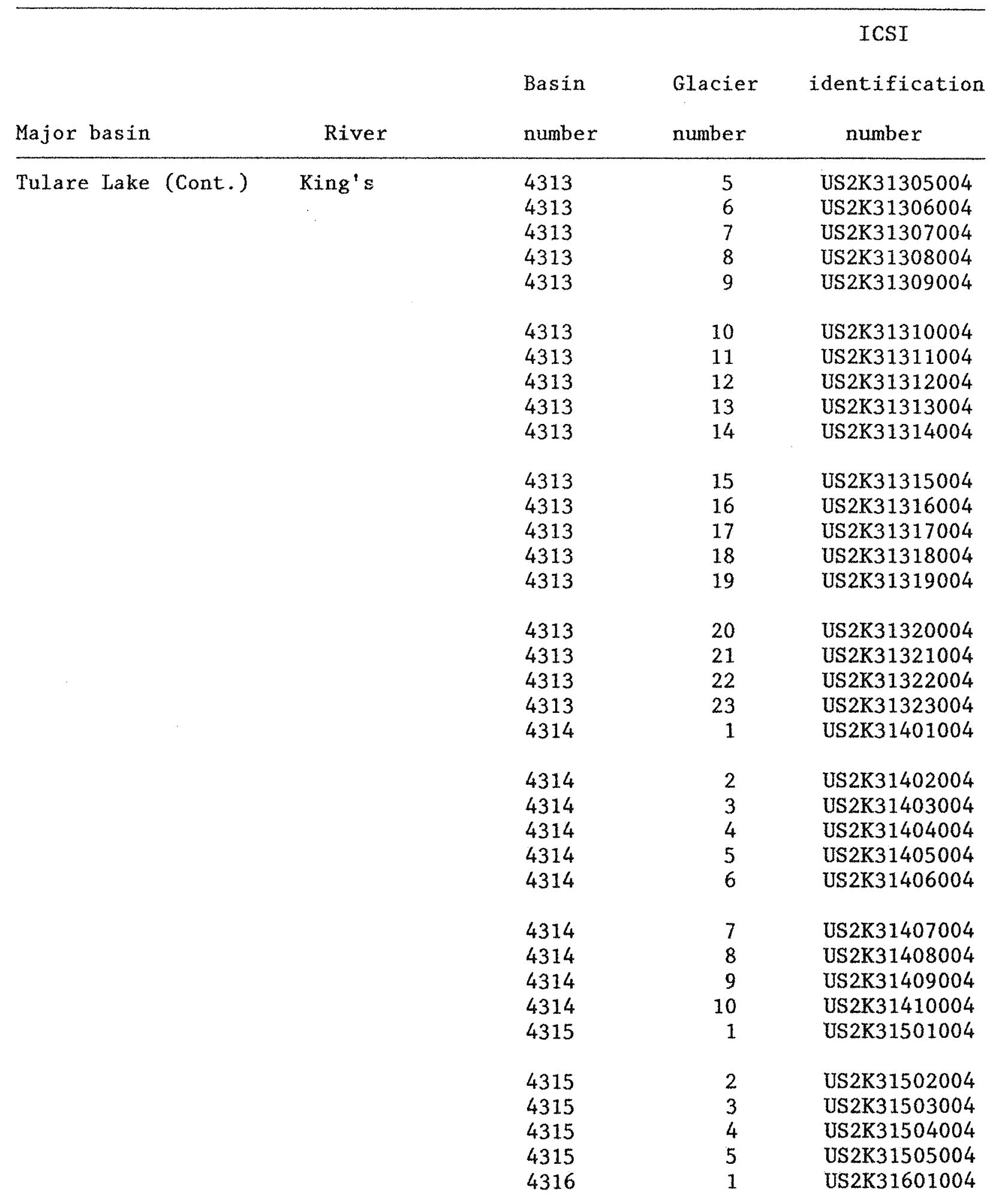


APPENDIX 2,--Glacier inventory numbering systems--Continued

U.S. Geological Survey

(Table 1A)

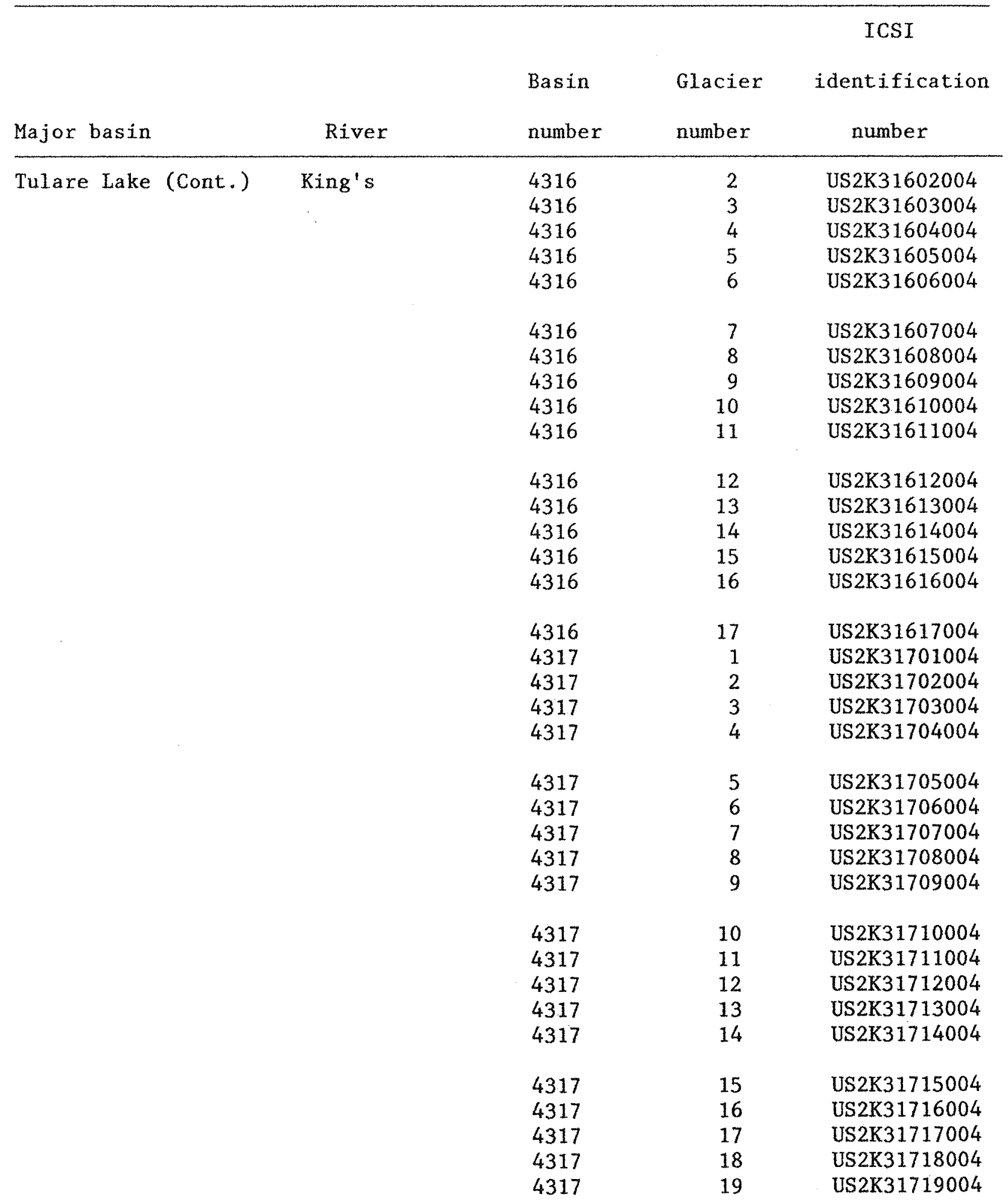


218 Inventory of Glaciers in the Sierra Nevada, California

APPENDIX 2.--Glacier inventory numbering systems--Continued

U.S. Geological Survey

(Table IA)

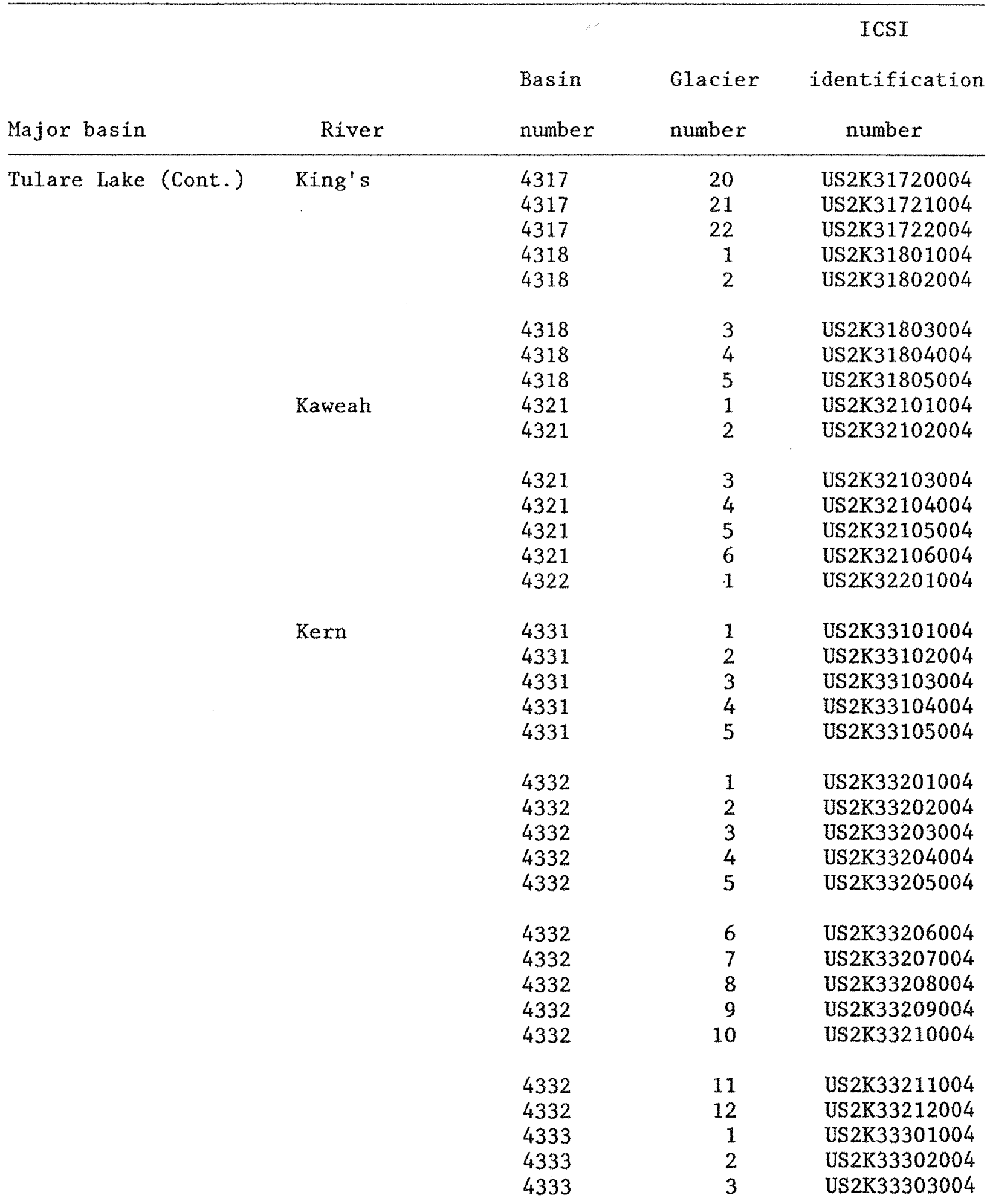


APPENDIX 2.--Glacier inventory numbering systems--Continued

U.S. Geological Survey

(Table 1A)

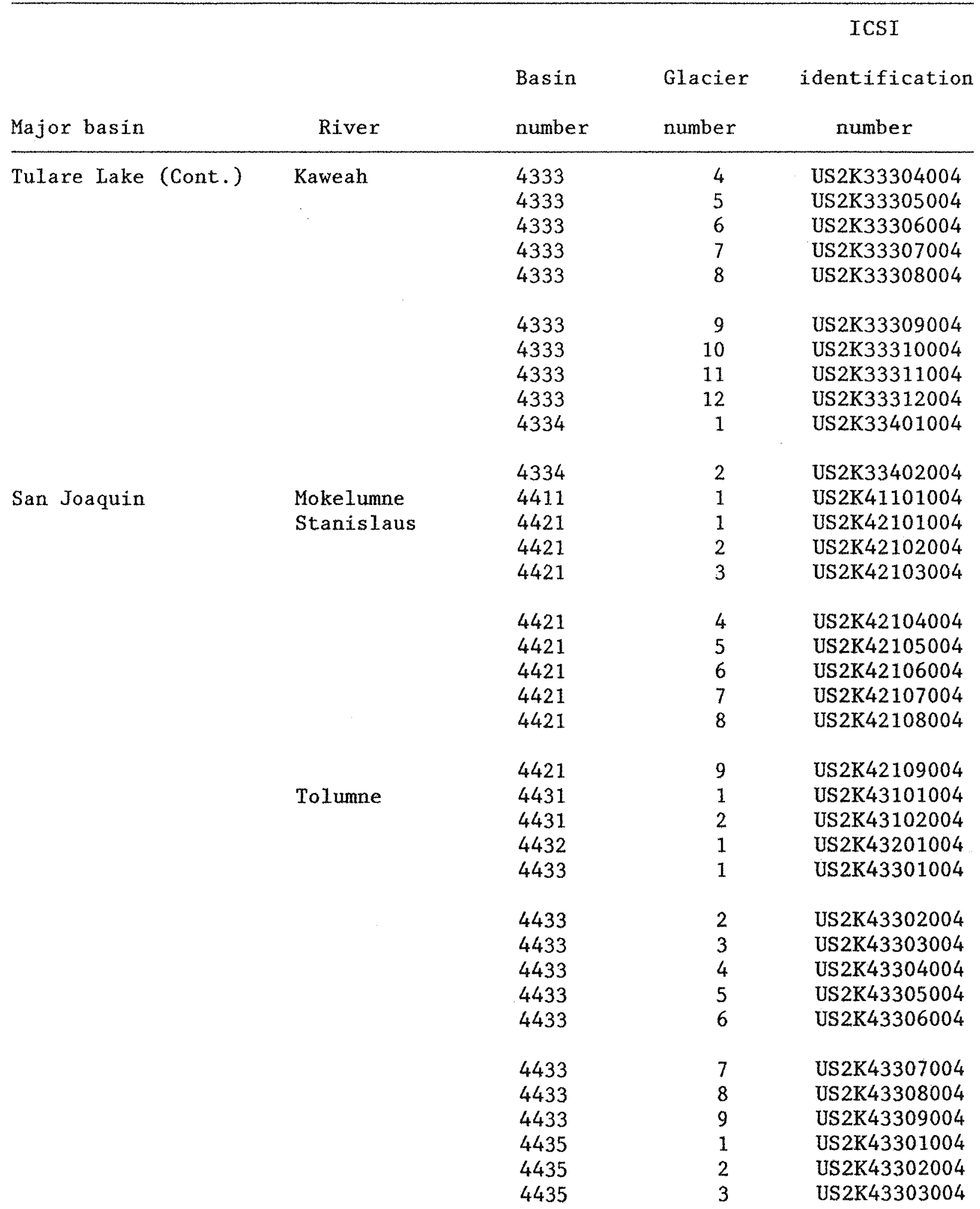


220 Inventory of Glaciers in the Sierra Nevada, California

APPENDIX 2.--Glacier inventory numbering systems--Continue

U.S. Geological Survey

(Table IA)

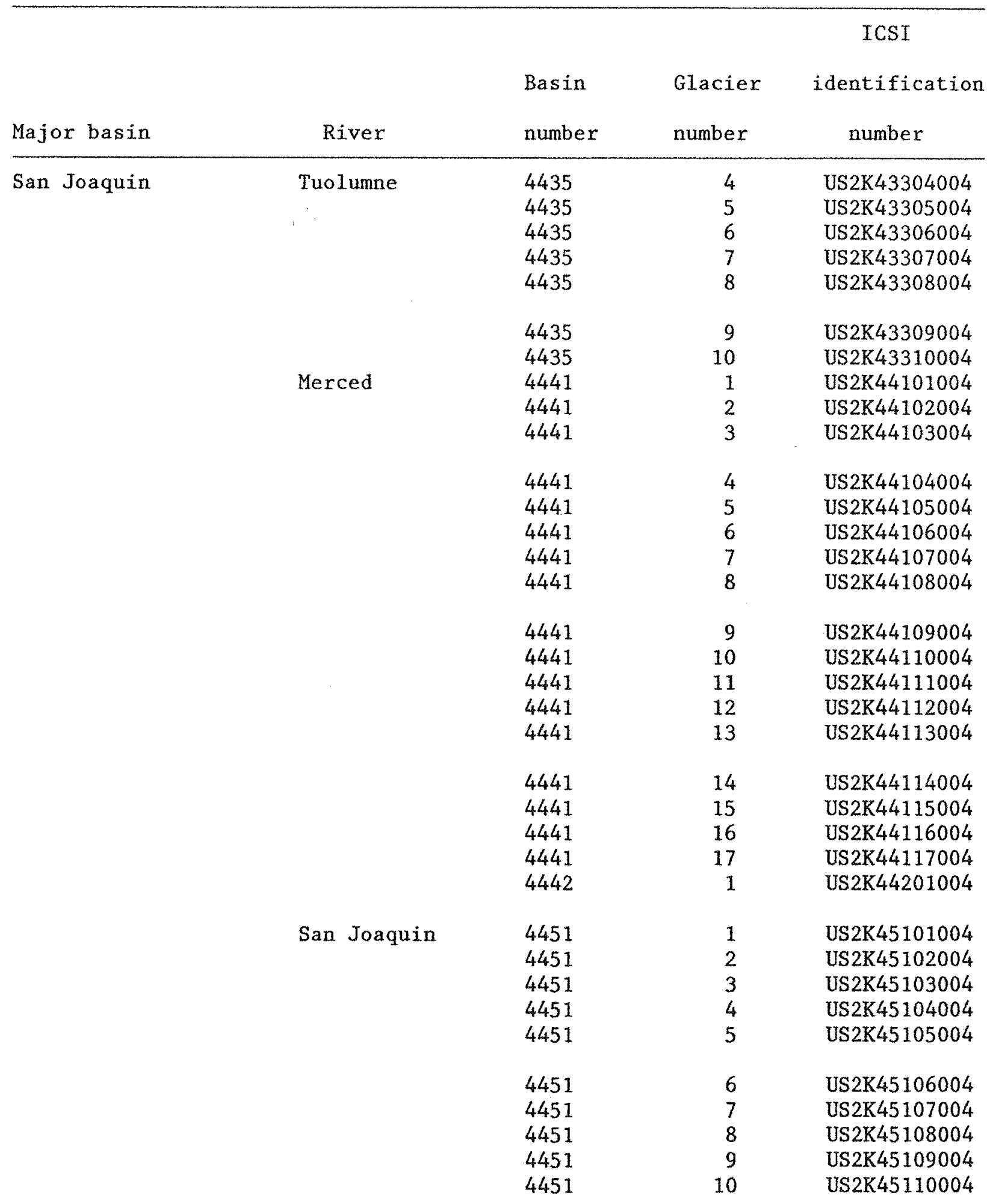


APPENDIX 2.--Glacier inventory numbering systems

U.S. Geological Survey

(Table 1A)

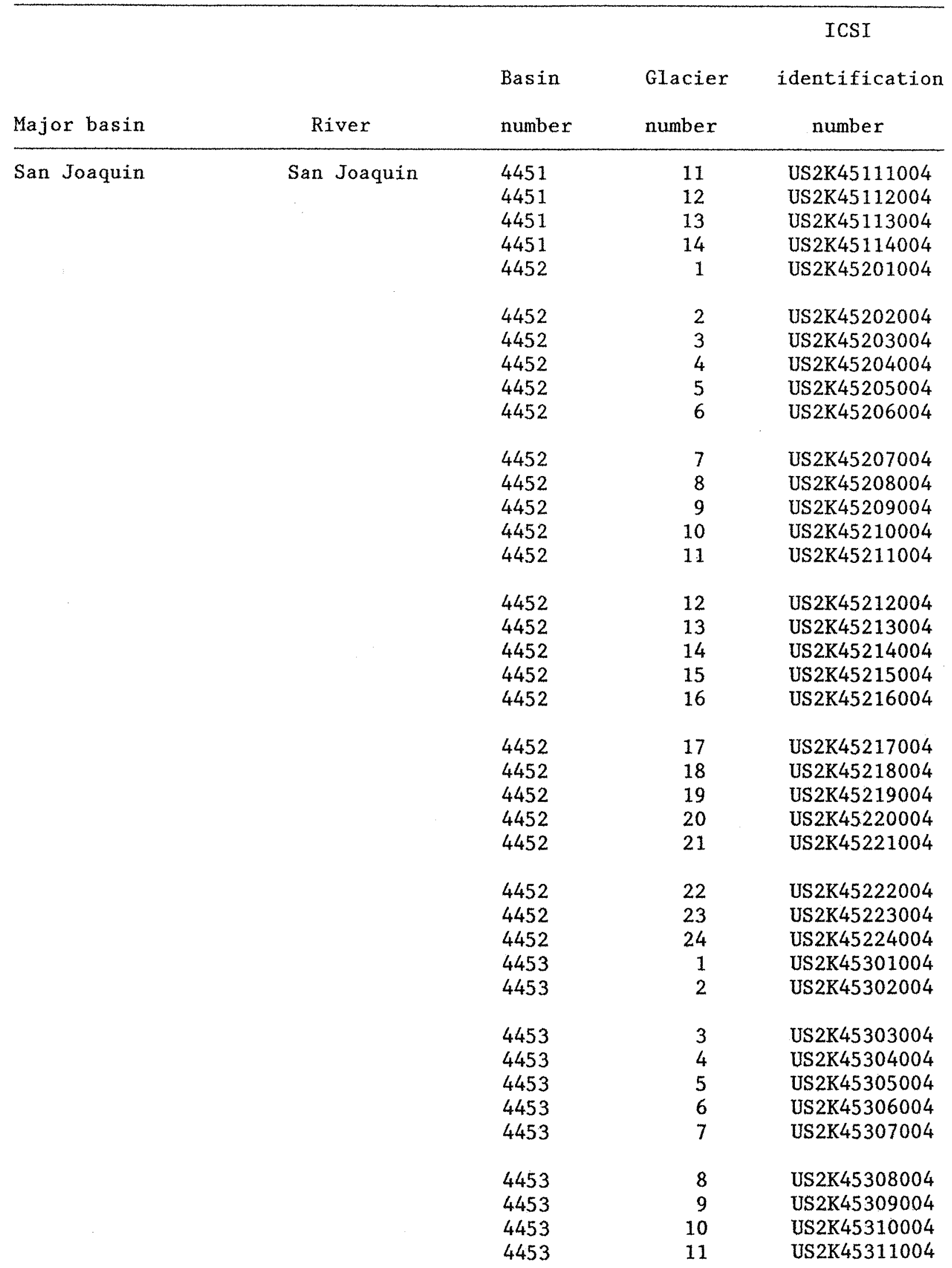


222 Inventory of Glaciers in the Sierra Nevada, California

APPENDIX 2.--Glacier inventory numbering systems--Continued

U.S. Geological Survey

(Table 1A)

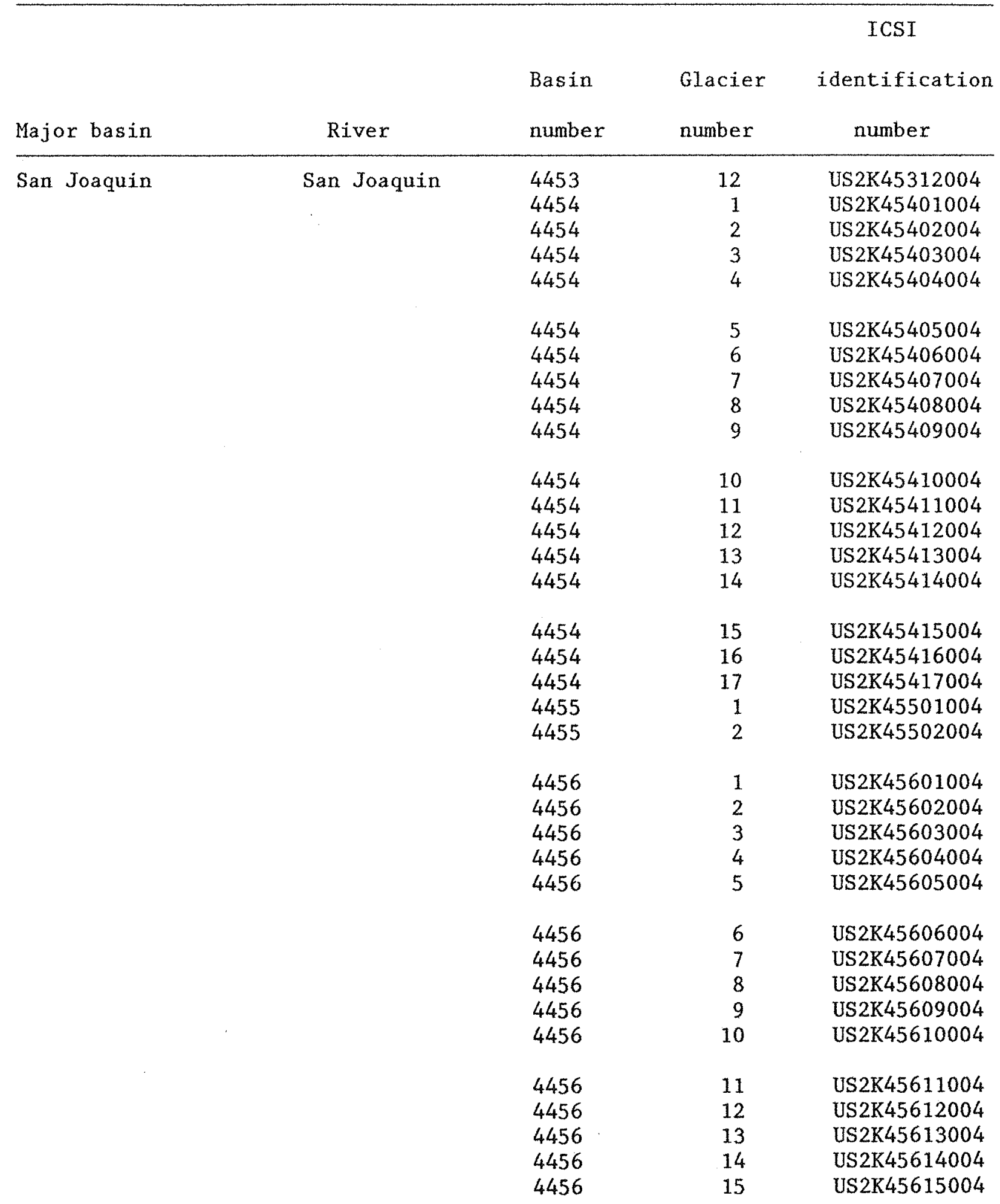


APPENDIX 2.--GIacier inventory numbering systems--Continued

U.S. Geological Survey

(Table 1A)

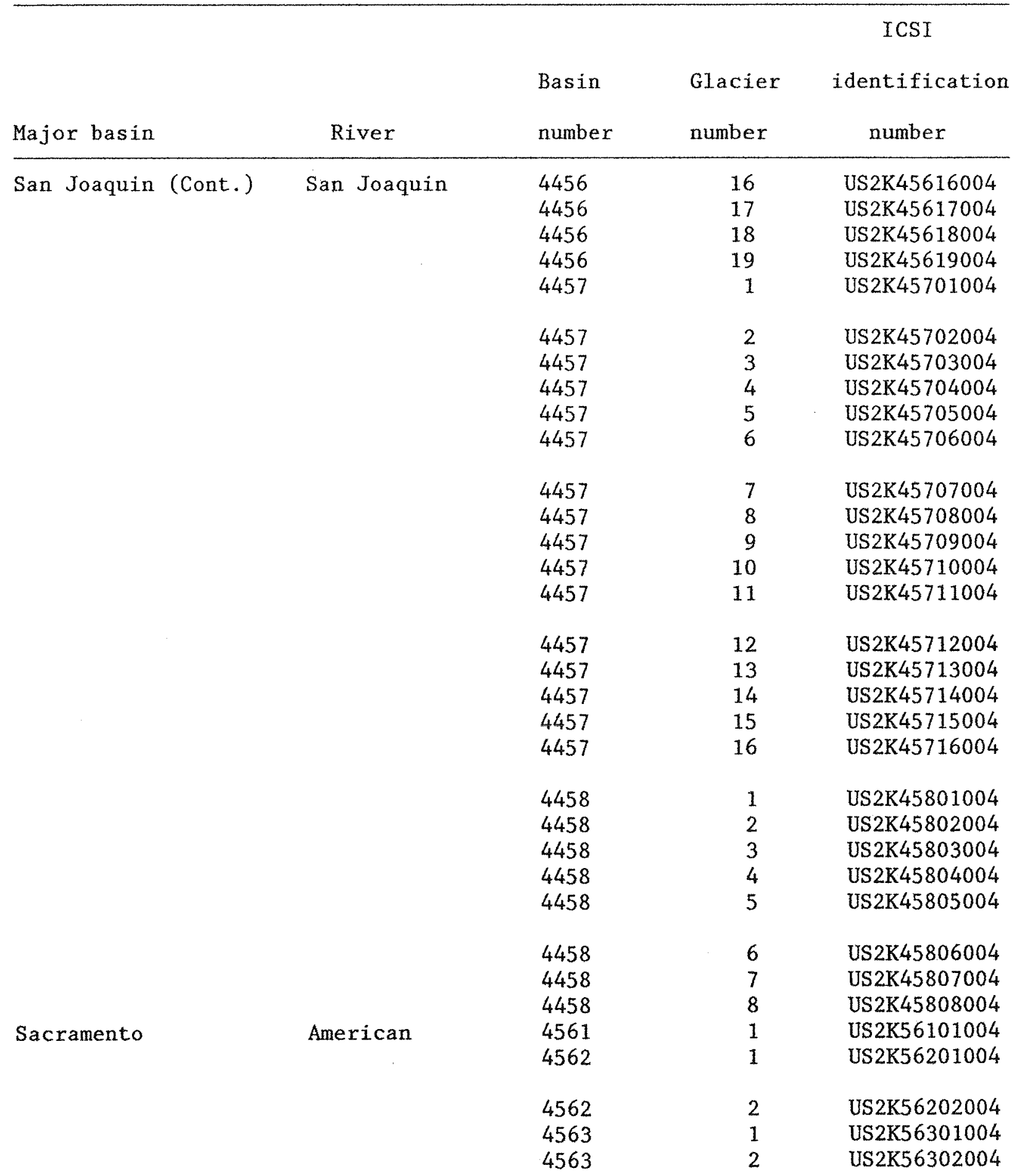




\section{DOCUMENT 2}

Data on 106 glaciers comprise the U.S. contribution to Fluctuations of Glaciers, Volume IV. All glaciers listed in the General Information Table have data in the present volume. The quadrangles referred to in the General Information are all U.S. Geological Survey topographic maps. The majority of the data is terminus variations 16 glaciers have terminus position addenda dating back at least 50 years (Columbia, 1899; Blue, 1938; Carrie, 1889; Eel, 1920; "Bear Pass", 1933; Unnamed \# 2123, 1933; Hoh, 1933; Ice River, 1924; Hubert, 1907; Black, 1924; White, 1924; Humes, 1907; Queets, 1913; Anderson, 1909; Grinnel1, 1925 and Sperry, 1935). There are 10 glaciers with mass balance and/or thickness change data. Pre-1975 mass balance versus altitude and thickness change data are given for 5 glaciers that were not included in Volume III. Some glaciers are measured using the fixed-date system, and some are measured using the stratigraphic system Gulkana and Wolverine have mass balance data also available from the investigators in the combined fixed-date/stratigraphic system. Seven glaciers have a gaging station and/or a meteorological station nearby. This low number of stations is an indication of how inaccessible most glaciers are in the U.S., especially those in Alaska. 
The first digit of the PSFG number for the U.S. glaciers denotes the state where the glacier is located the second digit denotes the range, the mountains, or a specific mountain:

1st-Digit

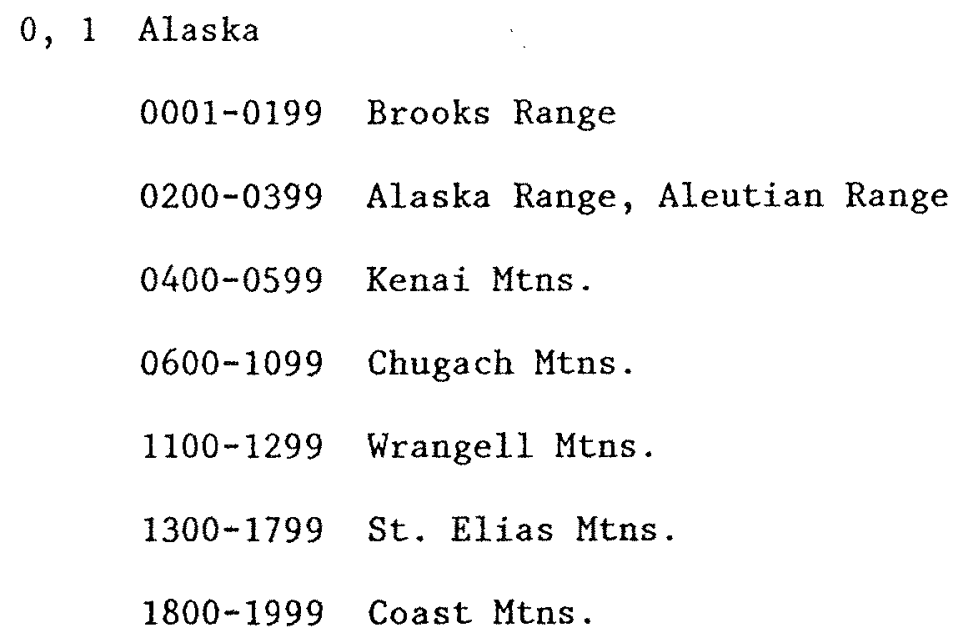


Sources of data and sponsoring agencies for the glaciers, listed in the order in which they appear in Table $\mathrm{A}$ are:

\author{
GuIkana--L.R. Mayo and D.C. Trabant (USGSF) \\ Falling to Taylor--W.O. Field (WOF) \\ Wolverine--L.R. Mayo and D.C. Trabant (USGSF) \\ Lawrence to Meares--W.O. Field (WOF) \\ Columbia USA627--A. Post and M.F. Meier (USGST), and L.R. Mayo and \\ D.C. Trabant (USGSF) \\ Shoup to Saddlebag--W.O. Field (WOF) \\ "Betseli" to Chetaslina--C. Benson, M. Sturm, P. Mackeith (UA) \\ Variegated--C.F. Raymond (UW) and W.D. Harrison (UA) \\ Geikie to Wright--W.O. Field (WOF) \\ Blue--R. Spicer (UW), B. Kamb and K. Echelmeyer (CalTech) \\ South Cascade--R.M. Krimmel (USGST) \\ Carbon to N. Mowich--C. Driedger (USGST) \\ Carrie to Anderson--R.C. Spicer (USGST) \\ Shoestring--M. Brugman (USGST) \\ Grinnell and Sperry--W.A. Blenkarn (USGSH) \\ Quelceaya Ice Cap--L. Thompson (OSU)
}


Abbreviations and addresses of sponsoring agencies:

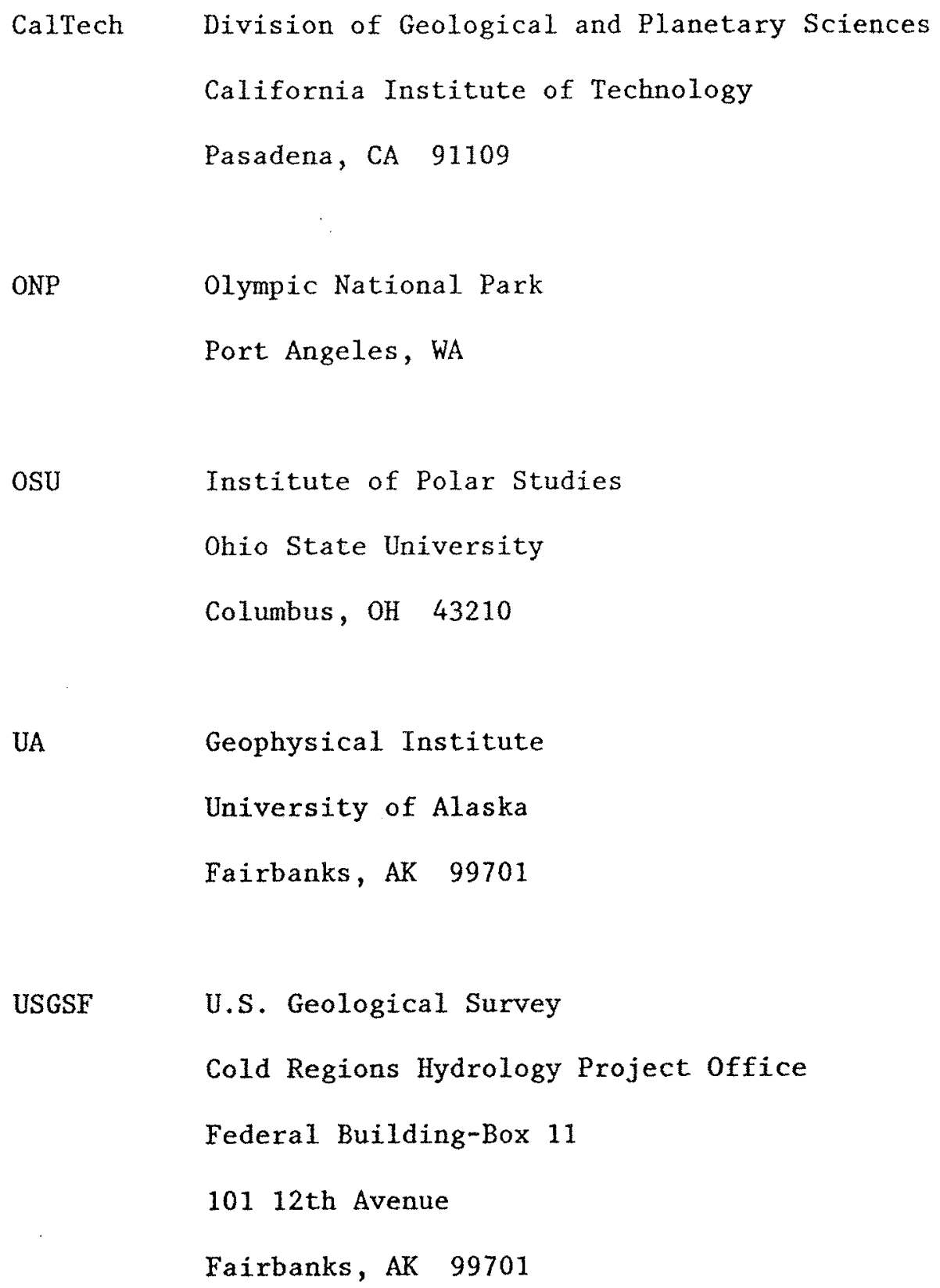


228 Inventory of Glaciers in the Sierra Nevada, California

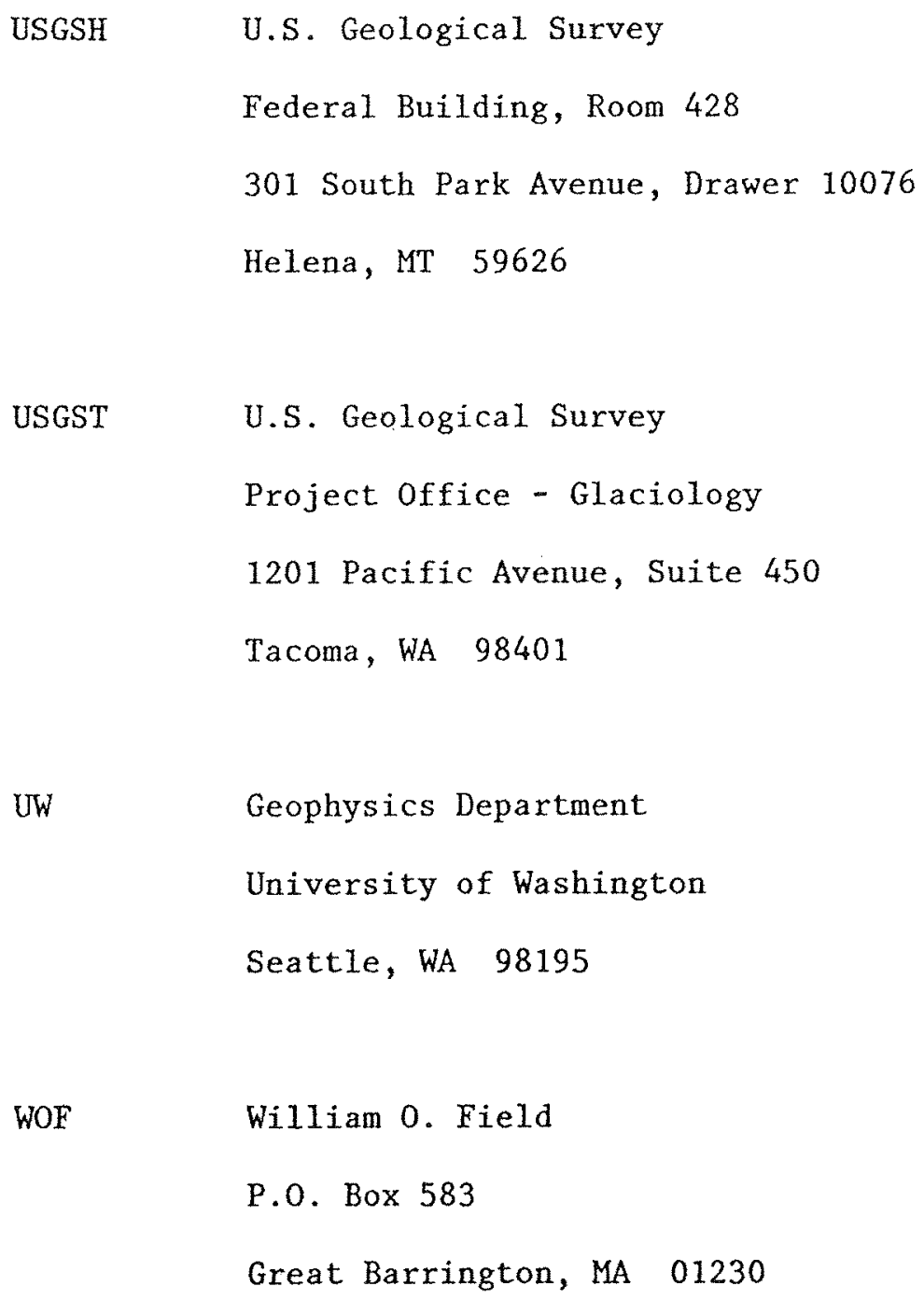



